WHC-SP-1123

UC-900

\title{
Safeguards and Security FY 1995 Site Support Program Plan WBS 6.6
}

D. J. Lemire

Date Published

September 1994

Prepared for the U.S. Department of Energy

(2) Westinghouse $\begin{aligned} & \text { P.o. Box } 1970 \\ & \text { Hanford Company }\end{aligned}$

Hanford Operations and Engineering Contractor for the

Approved for Public Release

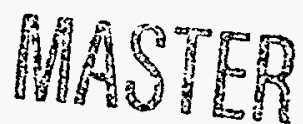




\section{LEGAL DISCLAIMER}

This report was prepared as an account of work sponsored by an agency of the United States Government. Neither the United States Government nor any agency thereof, nor any of their employees, nor any of their contractors, subcontractors or their employees, makes any warranty, express or implied, or assumes any legal liability or responsibility for the accuracy, completeness, or any third party's use or the results of such use of any information, apparatus, product, or process disclosed, or represents that its use would not infringe privately owned rights. Reference herein to any specific commercial product, process, or service by trade name, trademark, manufacturer, or otherwise, does not necessarily constitute or imply its endorsement, recommendation, or favoring by the United States Government or any agency thereof or its contractors or subcontractors. The views and opinions of authors expressed herein do not necessarily state or reflect those of the United States Government or any agency thereof.

This report has been reproduced from the best available copy. Available in paper copy and microfiche.

Available to the U.S. Department of Energy and its contractors from

Office of Scientific and Technical Information P.O. Box 62

Oak Ridge, TN 37831

(615) $576-8401$

Printed in the United States of America

DISCLM-3.CHP (1-91) 


\section{DISCLAIMER}

Portions of this document may be illegible in electronic image products. Images are produced from the best available original document. 


\section{RELEASE AUTHORIZATION}

Document Number: WHC-SP-1123

Document Title: $\quad$ Safeguards and Security FY 1995 Site Support Program P1an WBS 6.6

Release Date: $\quad$ September 28, 1994

This document was reviewed following the procedures described in WHC-CM-3-4 and is:

APPROVED FOR PUBLIC RELEASE

**************

WHC Information Release Administration Specialist:

M. Boston (Signature)
M. N. Boston

$\frac{9 / 28 / 94}{\text { (Date) }}$




\title{
Site Support Program Plan Approval Sheet
}

\author{
SAFEGUARDS AND SECURITY - WBS \#6.6
}

Assistant Manager-Contracting Officer's Representative

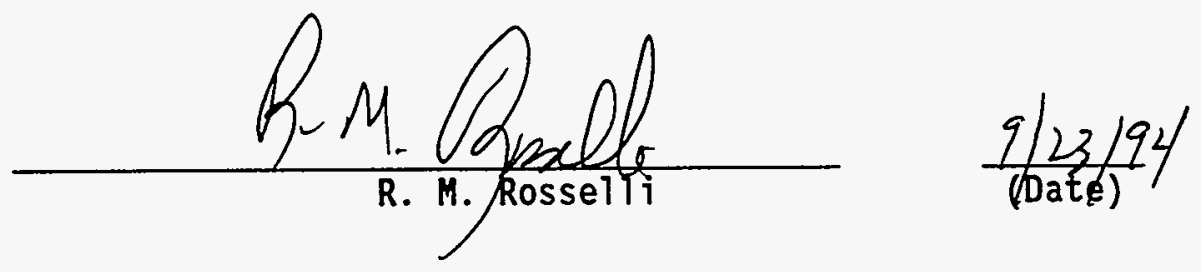

RL Program Manager

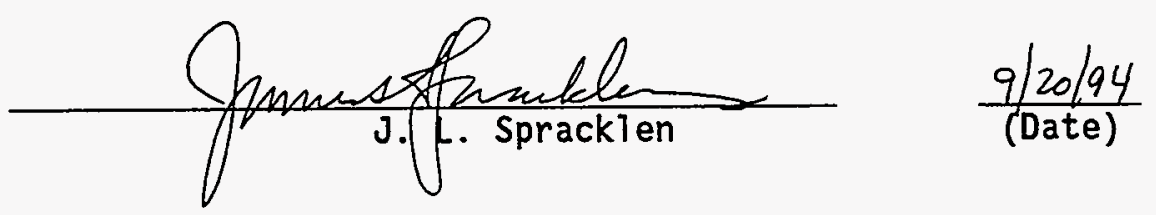

WHC Director

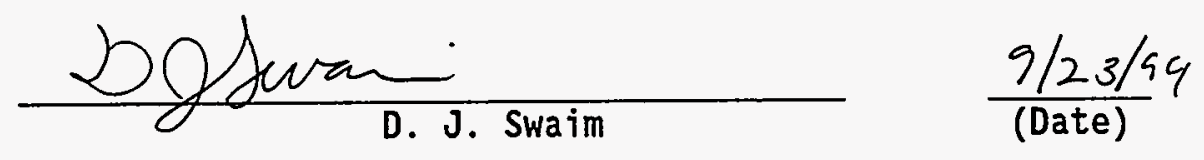

WHC Program Manager

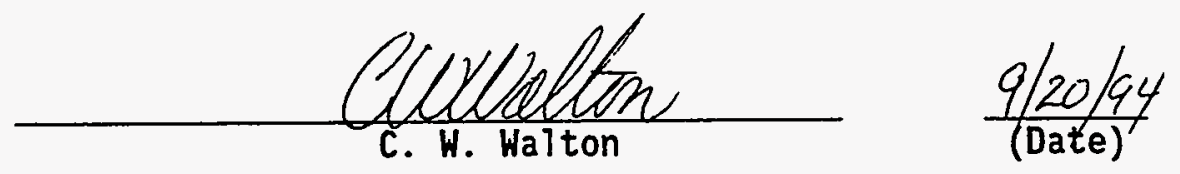




\section{CONTENTS \\ SAFEGUARDS AND SECURITY PROGRAM \\ 1995 FISCAL YEAR SITE SUPPORT PROGRAM PLAN \\ WBS 6.6}

1.0 OVERVIEW

1.A VISION/MISSION

1.B GOALS AND OBJECTIVES

I.C STRATEGIES

1.D ASSUMPTIONS

1.E ISSUES AND CONSTRAINTS

1.F PERFORMANCE MEASURES

2.0 BASELINES

2.A TECHNICAL BASELINE

2.B SCHEDULE BASELINE

2.C COST BASELINE

3.0 EXECUTION YEAR PACKAGE

3.A WBS DICTIONARY SHEETS

7.1.3 PFP

7.3.1 LMR

1.1.1 TWRS

$1.4 .1 \quad K$-BASINS

7.1.6.2.01 SNM MANAGEMENT

$7.1 .2 \quad 300$ AREA FUELS

7.1 .1 PUREX

6.6.1 PNL 


\section{CONTENTS}

SAFEGUARDS AND SECURITY PROGRAM

1995 FISCAL YEAR SITE SUPPORT PROGRAM PLAN

WBS 6.6

3.0 EXECUTION YEAR PACKAGE (CONT.)

3.A WBS DICTIONARY SHEETS (CONT.)

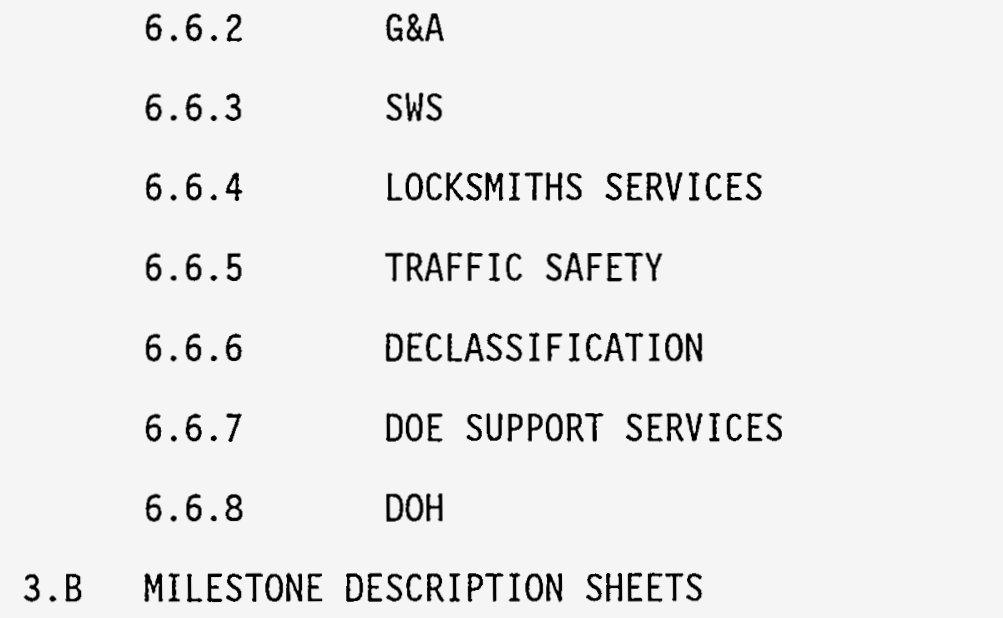




\begin{tabular}{|l|c|c|}
\hline & Westinghouse Hanford Company & FY 1995 \\
Safeguards and Security & WBS 6.6 & Site Support Program P1an \\
August 31, 1994
\end{tabular}

"The mission of the Safeguards and Security (SAS) program is, to ensure DOE interests, administered by WHC, are protected from loss, diversion, sabotage, espionage, theft and other hostile acts that may cause adverse impacts on national security, health, and safety of the public, employees or environment."

\section{$\underline{\text { Specific Missions }}$}

Maintain a standardized program for all WHC security functions on site. Program shall be consistent with current DOE Orders, RL Directives and Company security policies and procedures.

Physically protect SNM, classified matter, U.S. Government property and personnel located within the confines of the Hanford site.

Develop, maintain and implement policies and procedures governing the use, control and accountability of nuclear materials in compliance with DOE Orders.

Provide guidance, training and procedures to assure proper protection is afforded to classified matter and sensitive unclassified information which is processed, stored, transmitted or discussed throughout WHC.

Provide technical and analytical services which assist DOE in establishing and maintaining uniformed and cost-effective safeguards and security programs.

Coordinate and implement new security programs, systems and upgrades for newly constructed and existing facilities in order to protect Hanford interests.

Provide protection program planning, evaluation, and validation testing to ensure that levels of protection and risk are appropriate to site security interests that affect the protection of SNM and the health and safety of the public, on-site employees and the environment.

Develop, implement, and maintain policies and procedures governing the use and operation of government vehicles, roadways and pedestrian walkways on site, in compliance with DOE Orders, and Federal regulations. 


\begin{tabular}{|c|c|c|}
\hline 1.B Goals and Objectives & $\begin{array}{c}\text { Westinghouse Hanford Company } \\
\text { Safeguards and Security } \\
\text { WBS } 6.6\end{array}$ & $\begin{array}{c}\text { FY } 1995 \\
\text { Site Support Program Plan } \\
\text { August } 31 \text {, 1994 }\end{array}$ \\
\hline
\end{tabular}

\section{B.1 Customer Support}

Complete transition from a defense production program to one of supporting environmental restoration. Support DOE goal of increased openness with regard to SAS programs.

Support all WHC programs in achieving their missions through the utilization of a cost effective, technically proficient, and highly motivated SAS workforce.

Reduce length of time expended for the completion of corrective actions and closure of SAS findings.

Implement a declassification program utilizing a team concept with PNL and DOE-RL.

Continue the reduction of classified computers within WHC.

Support PFP Operations in implementation of full IAEA compliance for selected vaults.

Obtain a funding commitment, and implement as soon as feasible, the selected replacement option for the PFP nuclear accounting system and the computerized alarm monitoring system.

\section{Stretch Goal}

When it is proven the PC-based alarm monitoring system currently being tested at FFTF is technically feasible for operation at PFP and the PFP customer agrees to this approach, complete all engineering and procurement activity to support an installation date of November 1995.

Given that a technical solution based upon utilization of a database residing on a personal computer is agreed to for replacement of the nuclear material accounting system at PFP, complete all engineering and procurement activity by September 1995 to support installation in FY 1996. 


\begin{tabular}{|l|c|c|}
\hline & Westinghouse Hanford Company & FY 1995 \\
I.B Goals and 0bjectives & WBS 6.6 & Site Support Program Plan \\
August 31, 1994
\end{tabular}

\section{B.2 Production}

Maintain a $98 \%$ system uptime of the PFP security system.

Complete security upgrades for K-Basins by September 1995. Upgrades will allow for a decrease in SAS direct operational costs without any increase in risk.

Maintain the MBA Audit schedule without incurring slippage through close negotiation for critical PFP resources.

Improve operating efficiency by developing a program for outsourcing internal surveys of SAS major program elements.

\section{Stretch Goal}

Implement productivity improvements and eliminate low value work in order to reduce the department overhead rate. 


\begin{tabular}{|l|c|c|}
\hline & Westinghouse Hanford Company & FY 1995 \\
1.B Goals and Objectives & WBS 6.6 & $\begin{array}{c}\text { Site Support Program P1an } \\
\text { August 31, 1994 }\end{array}$ \\
\hline
\end{tabular}

\section{B.3 Organization and Management}

Implement behavior based safety programs across SAS organization.

Reduce lost workday cases in SAS by 50\% in FY 1995.

Reduce motor vehicle accidents in SAS by 50\% in FY 1995.

Maintain at least an 8 to 1 management to employee ratio.

Maintain a motivated, well trained SAS workforce.

Complete full in-house capability for SPO III training/certification.

Implement Acceptance Testing and Validation Order requirements.

Implement a program for closure of SSIMS findings using an RL approved Planning Priority Grid (PPG) model.

\section{Stretch Goal}

By the end of FY 1995, through outsourcing or elimination of low value work, achieve a organizational headcount for SAS of 375 down from 385 at the beginning of FY 1995. 


\begin{tabular}{|l|c|c|}
\hline & FY 1995 \\
1.C Strategies & $\begin{array}{c}\text { Westinghouse Hanford Company } \\
\text { Safeguards and Security } \\
\text { WBS 6.6 }\end{array}$ & $\begin{array}{c}\text { Site Support Program P1an } \\
\text { August 31, 1994 }\end{array}$ \\
\hline
\end{tabular}

\section{C.1 Customer Support Strategies}

The SAS program is becoming more customer oriented. While ensuring Programs and Facilities understand their SAS responsibilities, we will work even harder in a supportive role, by offering to assist in solving any SAS issues in the most cost effective manner. With a decreased staff and a broader span of management, the requirement for a well trained and highly motivated workforce becomes paramount. Our management team as well as our individual staff members will be empowered with increased responsibilities and authority, making customers our highest priority.

\section{C.2 Production Strategies}

A reduction of the cost of doing business through productivity enhancements and innovation will continue in the SAS program. At K-Basins, for example, an upgrade plan will be prepared that should allow for substantial SAS savings.

\section{C.3 Organization and Management Strategies}

SAS will inaugurate implementation of the behavior based safety program "DO RITE" in 1ate FY 1994, with full implementation in FY 1995. The SAS organization is committed to safety as a value and the behavior based safety approach will be utilized to ensure ownership of this value throughout the SAS organization. SAS will continue with monthly safety meetings and will further work to reduce safety incidents through safety improvement plans and lessons learned communications. 


\begin{tabular}{|l|c|c|}
\hline & Westinghouse Hanford Company & FY 1995 \\
1.D Assumptions/Priorities & Safeguards and Security & Site Support Program P1an \\
August 31,1994
\end{tabular}

General Assumptions

- Security clearance processing will be consolidated into a single DOE function which is to be completed in phases over the course of FY 1995.

- SAS will be responsible for rebadging all Hanford employees and subcontractor personnel.

- The Fast Flux Test Facility (FFTF) Category I material interests and the Plutonium Finishing Plant (PFP) will remain Protected Areas (Pas).

- Property protection areas and limited area islands will be maintained as required.

- Portions of Hanford SNM will be placed under IAEA inspection in FY 1995. Additional SNM will increasingly be placed under IAEA inspection through FY 2000.

- WHC will provide badging and protective force services for the ERC contractor (BHI). The ERC program will not require additional protective force positions.

- There will be no significant additions or reductions to special nuclear material inventories due to receipts or removals.

- Modified Safeguards and Security protection strategies may be required at Tank Farms, K Basins and B Plant to address specific conditions identified in Risk Assessments.

- Staffing for the site barricades will continue to be a non-security cost. Additional staffing will continue at the WYE Barricade for morning shift change.

- A new barricade will be opened off Highway 240. This will not be an SAS cost.

- Patrol will maintain a random search team and four site rovers. 


\begin{tabular}{|l|c|c|}
\hline & FY 1995 \\
1.D Assumptions/Priorities & $\begin{array}{c}\text { Westinghouse Hanford Company } \\
\text { Safeguards and Security } \\
\text { WBS } 6.6\end{array}$ & $\begin{array}{c}\text { Site Support Program P7an } \\
\text { August } 31,1994\end{array}$ \\
\hline
\end{tabular}

- Benton County Sheriff's Office (BCSO) funding is not a function of the contractor SAS program, however, it is identified in the contractor budgets for accounting purposes onty.

- Security investigations will be conducted only for incidents defined as significant by RL and event trending and analysis will be performed to identify significant events/trends.

- A DOE common badge wiTl be implemented upon final HQ approval across the DOE complex significantly reducing the need for issuing off-site visitor badges .

- Access administration requirements for DOE classified visits to Hanford will be reduced further.

- The current NM accounting system will be maintained until a replacement is available.

- Plans to integrate the Patrol Operations Center activities into a Site Central Dispatch Center will continue. Cost and headcount for the SAS function at the dispatch center will remain in the SAS planning.

- There will be an increased emphasis placed on the Counterintelligence and the Operations Security Program as a result of treaty inspections, IAEA, FNVA's, and increased espionage threats.

- Classified work will continue to be consolidated to a minimum number of limited area islands.

- Sensitive unclassified work needs to be identified and consolidated to the lowest practical number of site locations.

- DOE Security Clearance levels will be reduced from previous years.

- A HQ Security Evaluations SSRR review will be conducted at Hanford in FY 1995 and a comprehensive I\&E will be conducted at Hanford in FY 1996.

- Document declassification activities will increase and remain at a high level through FY 2000. 


\begin{tabular}{|l|c|c|}
\hline & Westinghouse Hanford Company & FY 1995 \\
Safeguards and Security & WBS 6.6 & $\begin{array}{c}\text { Site Support Program P1an } \\
\text { August 31, 1994 }\end{array}$ \\
\hline
\end{tabular}

- WHC will implement the use of "Building Specific" badges at the Hanford Site.

- SAS systems for nuclear material protection, control, and accounting at the PFP will have high operational risks by FY 1996. Compensatory measures will be developed and replacement planning will proceed consistent with available resources.

- Hanford Patrol wi11 conduct one Basic Training class for new recruits in FY 1995 and one in FY 1996.

- Safeguards (MC\&A) will participate, as required, toward a site goal to remove and consolidate excess nuclear materials from the 300 Area to the 200 Areas.

- SAS will interact with Human Resources and others to assure development/operations of an effective policy on violence in the workplace.

- SAS will implement a program to outsource internal surveys of SAS major program elements. 


\begin{tabular}{|l|c|c|}
\hline & $\begin{array}{c}\text { Westinghouse Hanford Company } \\
\text { Safeguards and Security } \\
\text { WBS } 6.6\end{array}$ & $\begin{array}{c}\text { Site Support Program Plan } \\
\text { August 31, 1994 }\end{array}$ \\
\hline
\end{tabular}

\section{Priorities}

- Protection of SNM, Classified Matter, Public Health, and Safety

- $\quad$ Systems replacement efforts

- $\quad$ 100K RAD/SAB mitigation

- RAD/TOX SAB assessments

- Tank Farms VA mitigation

- Protective Force Deployment

- Requirements/Regulations

- $\quad$ SSIMS finding closure per PPG

- New requirements implementation

$$
\text { - Acceptance testing and validation }
$$

$$
\text { - Training order/TAP }
$$

- Declassification/openness initiative

- Rebadging

- IAEA Safeguards/treaty implementation

- Better Business Practices

- Entry Center project

- Heads project

- Technology application to reduce resource needs

$$
\text { - DISS/ET }
$$

- FOB upgrades

- Smart Cards

- Computer based training

- Long distance learning

- Tactical Shoothouse

- Risk management vs. order compliance 


\begin{tabular}{|c|c|c|}
\hline 1.E Issues and Constraints & $\begin{array}{c}\text { Westinghouse Hanford Company } \\
\text { Safeguards and Security } \\
\text { WBS } 6.6\end{array}$ & $\begin{array}{c}\text { FY } 1995 \\
\text { Site Support Program Plan } \\
\text { August } 31,1994\end{array}$ \\
\hline
\end{tabular}

A significant transition of the SAS program at Hanford has occurred during the past two years. Mission programs supporting defense production have evolved to programs supporting environmental restoration. Substantial reductions of SAS requirements and a corresponding reduction in SAS resources were necessitated by this change. A significant issue facing the SAS program in FY 1995 is continued productivity improvement, due to the reductions in resources that occurred in FY 1993 and FY 1994. Another issue is increasing requirements in some areas while a decrease in budget is the desired goal. For example, training requirements continue to be increased for SAS personnel but may prove impossible to implement given the fiscal constraints currently mandated. Flexibility of the program has become limited with budget reductions. The ability of SAS to quickly implement new requirements is not what it has been in the past. For example, Protective Force personnel are severely stretched and it takes up to six months to hire new personnel to augment the force. If a sudden change is mandated whereby additional patrol response or rovers are required it will be a lengthy implementation. 


\begin{tabular}{|c|c|c|}
\hline 1.F Performance Measures & $\begin{array}{c}\text { Westinghouse Hanford Company } \\
\text { Safeguards and Security } \\
\text { WBS } 6.6\end{array}$ & $\begin{array}{c}\text { FY } 1995 \\
\text { Site Support Program P1an } \\
\text { August 31, 1994 }\end{array}$ \\
\hline
\end{tabular}

SAS program performance is monitored against a solid baseline of work plans. Performance measures include, adherence to schedule, monthly budget versus cost, financial analysis and qualitative evaluations, such as technical and customer support. The Site Management System (SMS) is utilized to report performance measures to RL on a monthly basis. A monthiy evaluation and recap is transmitted and briefed in a team setting with WHC and RL SAS management. Quarterly cost and obligation reports are al so prepared for DOE-HQ. They compare SAS costs to the planned crosscut budget for the fiscal year. 


\begin{tabular}{|c|c|c|c|c|c|}
\hline \multicolumn{2}{|c|}{$\begin{array}{l}\text { 2.A.1 } \\
\text { Work Breakdown Structure and } \\
\text { Responsibility Assignment Matrix }\end{array}$} & \multicolumn{2}{|c|}{$\begin{array}{c}\text { Westinghouse Hanford Company } \\
\text { Safeguards and Security } \\
\text { WBS } 6.6\end{array}$} & \multicolumn{2}{|c|}{$\begin{array}{c}\text { FY } 1995 \\
\text { Site Support Program Plan } \\
\text { August 31, } 1994 \\
\end{array}$} \\
\hline Program Element & $\begin{array}{c}\text { Activity/Program } \\
\text { Sub-Element }\end{array}$ & Cost Account & Title & $\begin{array}{l}\text { Responsible } \\
\text { Manager }\end{array}$ & $\begin{array}{r}\text { Responsible } \\
\text { Organization } \\
\end{array}$ \\
\hline 6.6 .1 & 6.6 .1 & PNL & Patrol Support to PNL & V. G. Heiman & $3 \mathrm{~B} 500$ \\
\hline 6.6 .2 & 6.6 .2 .1 & G\&A & Access Control & W. J. Hawkins & $3 \mathrm{~B} 300$ \\
\hline 6.6 .2 & 6.6 .2 .3 & G\&A & $\begin{array}{l}\text { Security } \\
\text { Investigations }\end{array}$ & D. W. Engel & $3 \mathrm{~B} 200$ \\
\hline 6.6 .2 & 6.6 .2 .4 & G\&A & Security Education & D. J. Haskins & $3 B 110$ \\
\hline 6.6 .3 & 6.6 .3 .1 & SWS & Patrol Site Support & V. G. Heiman & $3 \mathrm{~B} 500$ \\
\hline 6.6 .3 & 6.6 .3 .2 & SWS & $\begin{array}{l}\text { Assessments and } \\
\text { Performance Testing }\end{array}$ & G. W. Curtis & $3 \mathrm{~B} 230$ \\
\hline
\end{tabular}

Note: Direct workscope is not included in WBS 6.6 (SAS) but is controlled through the various program plans for facilities requiring SAS services. Summary level workscope and budget projections for direct workscope have been included in this document in order for a total SAS cost baseline to be developed. Any change control required in direct work in FY 1995 will be processed through program offices for approval while SAS site wide activities will be managed for change control through RL-SAS. 


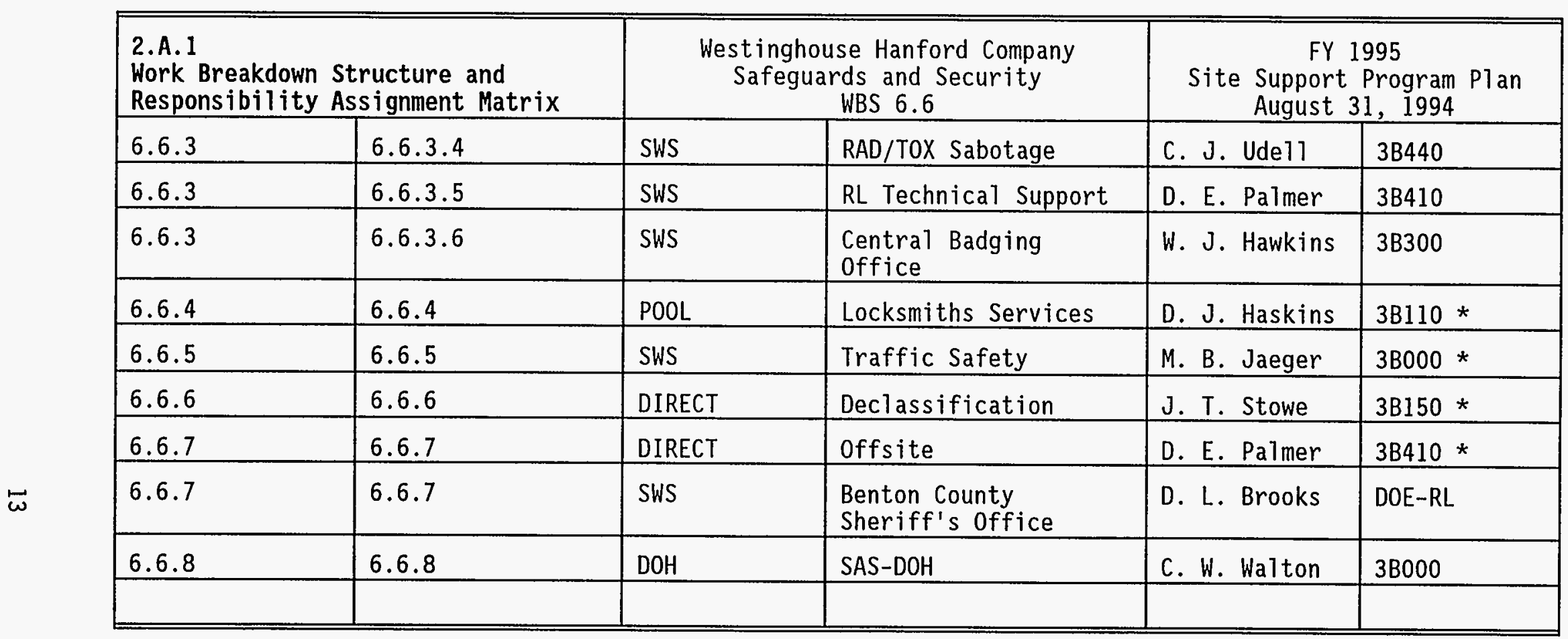

* Not SAS costs to Hanford. 


\begin{tabular}{|c|c|c|c|c|c|c|}
\hline \multicolumn{3}{|c|}{ 2.B.1 Milestone List } & \multicolumn{2}{|c|}{$\begin{array}{c}\text { Westinghouse Hanford Company } \\
\text { Safeguards and Security } \\
\text { WBS } 6.6\end{array}$} & \multicolumn{2}{|c|}{$\begin{array}{c}\text { FY } 1995 \\
\text { Site Support Program Plan } \\
\text { August } 31, \quad 1994 \\
\end{array}$} \\
\hline \multicolumn{2}{|c|}{ Milestone } & \multirow{2}{*}{$\begin{array}{l}\text { WBS } \\
\text { Number }\end{array}$} & \multirow{2}{*}{\multicolumn{3}{|c|}{ Milestone Description }} & \multirow{3}{*}{$\begin{array}{l}\text { Due } \\
\text { Date }\end{array}$} \\
\hline Type & Number & & & & & \\
\hline & & & Description & Assignee & Deliverable & \\
\hline DOE-RL & SSP-95-01 & 6.6 .3 .4 & FY 1995 Hanford SSSP & C. J. Udell & Report & $9 / 30 / 95$ \\
\hline DOE-RL & SSP-95-02 & 6.6 .3 .1 & $\begin{array}{l}\text { Reduce Overtime } \\
\text { Training by } 15 \% \\
\end{array}$ & B. W. Cameron & Report & $9 / 30 / 95$ \\
\hline DOE-RL & SSP-95-03 & 6.6 .3 .1 & $\begin{array}{l}\text { Single Site } \\
\text { Contingency Plan }\end{array}$ & G. P. Mcdowe11 & Letter & $5 / 31 / 95$ \\
\hline DOE-RL & SSP-95-04 & 6.6 .3 .1 & $\begin{array}{l}\text { Establishment of Long } \\
\text { Distance Learning }\end{array}$ & B. W. Cameron & Letter & $9 / 30 / 95$ \\
\hline DOE-RL & SSP-95-05 & 6.6 .3 .4 & FY 1994 Hanford SSSP & C. J. Ude11 & Report & $11 / 30 / 94$ \\
\hline DOE-RL & SSP-95-06 & 6.6 .2 .1 & $\begin{array}{l}\text { Implement New } \\
\text { Personnel Security } \\
\text { Clearance Record } \\
\text { System }\end{array}$ & W. J. Hawkins & Letter & $2 / 1 / 95$ \\
\hline DOE-RL & SSP-95-07 & 6.6 .2 .1 & $\begin{array}{l}\text { Complete Hanford Site } \\
\text { Rebadging Project }\end{array}$ & W. J. Hawkins & Letter & $1 / 31 / 95$ \\
\hline DOE-RL & SSP-95-08 & 6.6 .2 .4 & $\begin{array}{l}1994 \text { Security } \\
\text { Refresher Briefing }\end{array}$ & C. E. Braswell & Report & $3 / 31 / 95$ \\
\hline DOE-RL & SSP-95-09 & 6.6 .2 .4 & $\begin{array}{l}1995 \text { Security } \\
\text { Refresher Briefing }\end{array}$ & C. E. Braswell & Letter & $1 / 1 / 95$ \\
\hline
\end{tabular}




\begin{tabular}{|c|c|c|c|c|c|c|}
\hline \multicolumn{3}{|c|}{ 2.B.1 Milestone List } & \multicolumn{2}{|c|}{$\begin{array}{c}\text { Westinghouse Hanford Company } \\
\text { Safeguards and Security } \\
\text { WBS } 6.6\end{array}$} & \multicolumn{2}{|c|}{$\begin{array}{c}\text { FY } 1995 \\
\text { Site Support Program Plan } \\
\text { August } 31,1994 \\
\end{array}$} \\
\hline \multicolumn{2}{|c|}{ Milestone } & \multirow{2}{*}{$\begin{array}{l}\text { WBS } \\
\text { Number }\end{array}$} & \multirow{2}{*}{\multicolumn{3}{|c|}{ Milestone Description }} & \multirow{3}{*}{$\begin{array}{l}\text { Due } \\
\text { Date }\end{array}$} \\
\hline Type & Number & & & & & \\
\hline & & & Description & Assignee & Deliverable & \\
\hline DOE-RL & SSP-95-10 & 7.1 .6 .2 .01 & $\begin{array}{l}\text { Accounting System } \\
\text { Replacement - } \\
\text { Contingency Plan }\end{array}$ & D. W. Engel & Report & $1 / 31 / 95$ \\
\hline DOE-RL & SSP-95-11 & 6.6 .3 .2 & $\begin{array}{l}\text { Response to DOE Order } \\
5630.16 \mathrm{~A} \\
\text { (Implementation of } \\
\text { Performance Test } \\
\text { Program) }\end{array}$ & D. W. Engel & Letter & $8 / 25 / 95$ \\
\hline DOE-RL & SSP-95-12 & 6.6 .2 .2 & $\begin{array}{l}\text { Develop computer } \\
\text { assisted training } \\
\text { package for classified } \\
\text { computer users in WHC }\end{array}$ & J. T. Stowe & $\begin{array}{l}\text { Computer } \\
\text { Software }\end{array}$ & $6 / 30 / 95$ \\
\hline DOE-RL & SSP-95-13 & 6.6 .2 .2 & $\begin{array}{l}\text { WHC 0perations } \\
\text { Security Plan for } \\
\text { FY } 95\end{array}$ & J. T. Stowe & Report & $10 / 1 / 94$ \\
\hline DOE-RL & SSP-95-14 & 6.6 .2 .2 & $\begin{array}{l}\text { Training package for } \\
\text { unclassified computer } \\
\text { security awareness }\end{array}$ & J. T. Stowe & $\begin{array}{l}\text { Computer } \\
\text { Software }\end{array}$ & $3 / 31 / 95$ \\
\hline DOE-RL & SSP-95-15 & 6.6 .2 .2 & $\begin{array}{l}\text { Update/revise the WHC } \\
\text { Computer Protection } \\
\text { Program Plan }\end{array}$ & J. T. Stowe & Report & $6 / 30 / 95$ \\
\hline
\end{tabular}




\begin{tabular}{|c|c|c|c|c|c|c|}
\hline \multicolumn{3}{|c|}{ 2.B.1 Milestone List } & \multicolumn{2}{|c|}{$\begin{array}{c}\text { Westinghouse Hanford Company } \\
\text { Safeguards and Security } \\
\text { WBS } 6.6\end{array}$} & \multicolumn{2}{|c|}{$\begin{array}{c}\text { FY } 1995 \\
\text { Site Support Program Plar } \\
\text { August 31, } 1994\end{array}$} \\
\hline \multicolumn{2}{|c|}{ Milestone } & \multirow{2}{*}{$\begin{array}{c}\text { WBS } \\
\text { Number }\end{array}$} & \multirow{2}{*}{\multicolumn{3}{|c|}{ Milestone Description }} & \multirow{3}{*}{$\begin{array}{l}\text { Due } \\
\text { Date }\end{array}$} \\
\hline Type & Number & & & & & \\
\hline & & & Description & Assignee & Deliverable & \\
\hline CNTR & SSP-95-16 & 6.6 .3 .2 & Internal Audit Program & D. W. Engel & Letter & $2 / 28 / 95$ \\
\hline DOE-RL & SSP-95-17 & 6.6.3.2 & $\begin{array}{l}\text { SAS Topical Area } \\
\text { Internal Surveys }\end{array}$ & D. W. Engel & Report & $8 / 31 / 95$ \\
\hline DOE-RL & SSP-95-18 & 6.6 .6 & $\begin{array}{l}\text { Declassification } \\
\text { Review and Monthly } \\
\text { Reports }\end{array}$ & J. T. Stowe & Report & $12 / 30 / 94$ \\
\hline DOE-RL & SSP-95-19 & 6.6.6 & $\begin{array}{l}\text { Declassification } \\
\text { Inventory of WHC } \\
\text { Documents }\end{array}$ & J. T. Stowe & Report & $3 / 31 / 95$ \\
\hline & & & & & & \\
\hline & & & & & & \\
\hline & & & & & & \\
\hline & & & & & & \\
\hline & & & & & & \\
\hline
\end{tabular}




\begin{tabular}{|c|c|c|}
\hline $\begin{array}{c}\text { SSPP } \\
\text { FY 1995 }\end{array}$ & $\begin{array}{c}\text { WESTINGHOUSE HANFORD COMPANY } \\
\text { 6.6 SAFEGUARDS AND SECURITY }\end{array}$ & OCTOBER 1994 \\
\hline
\end{tabular}

MILESTONE SCHEDULE

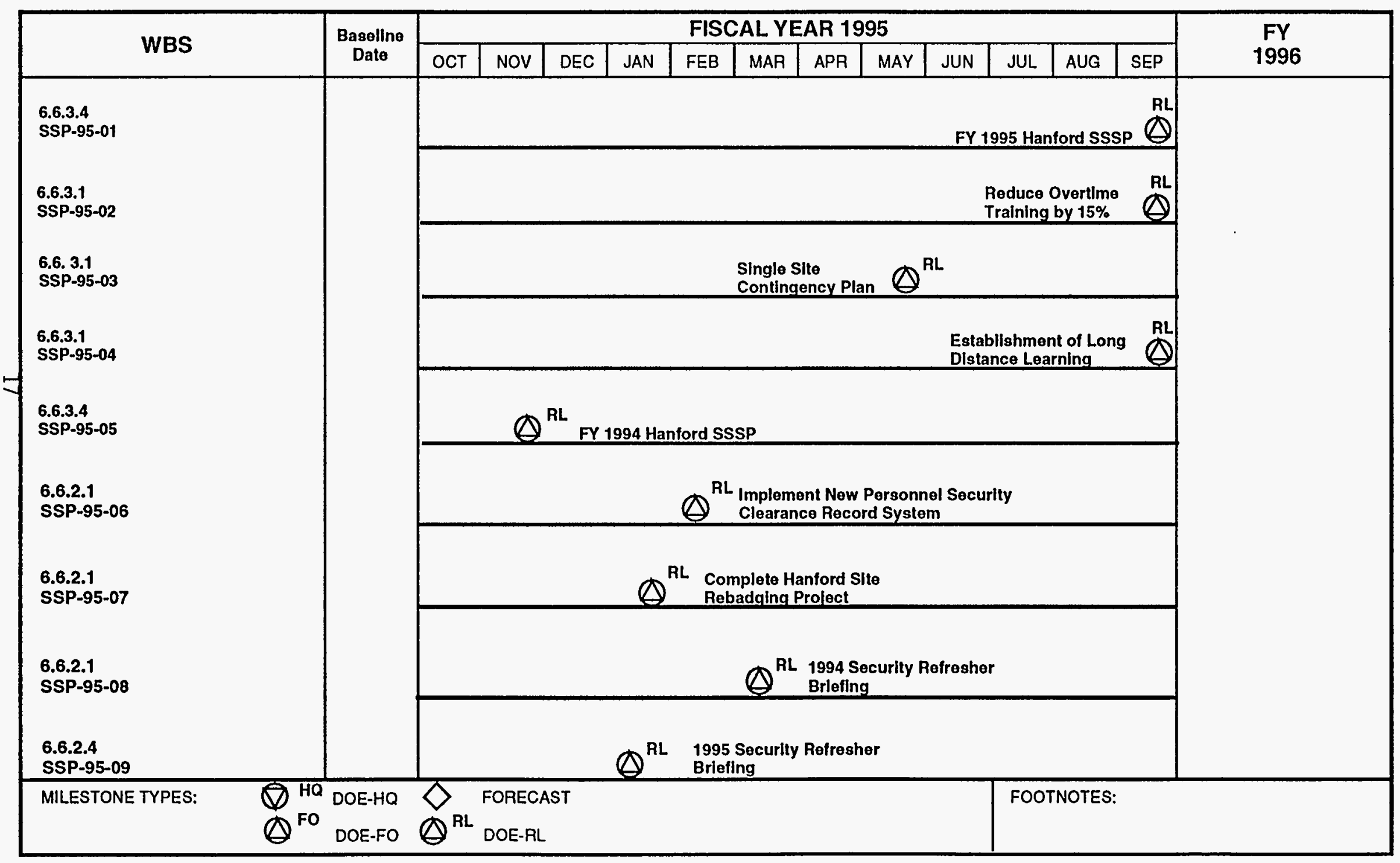




\begin{tabular}{|c|c|c|}
\hline SSPP & WESTINGHOUSE HANFORD COMPANY & OCTOBER 1994 \\
FY 1995 & 6.6 SAFEGUARDS AND SECURITY & \\
\hline
\end{tabular}

\section{MILESTONE SCHEDULE}

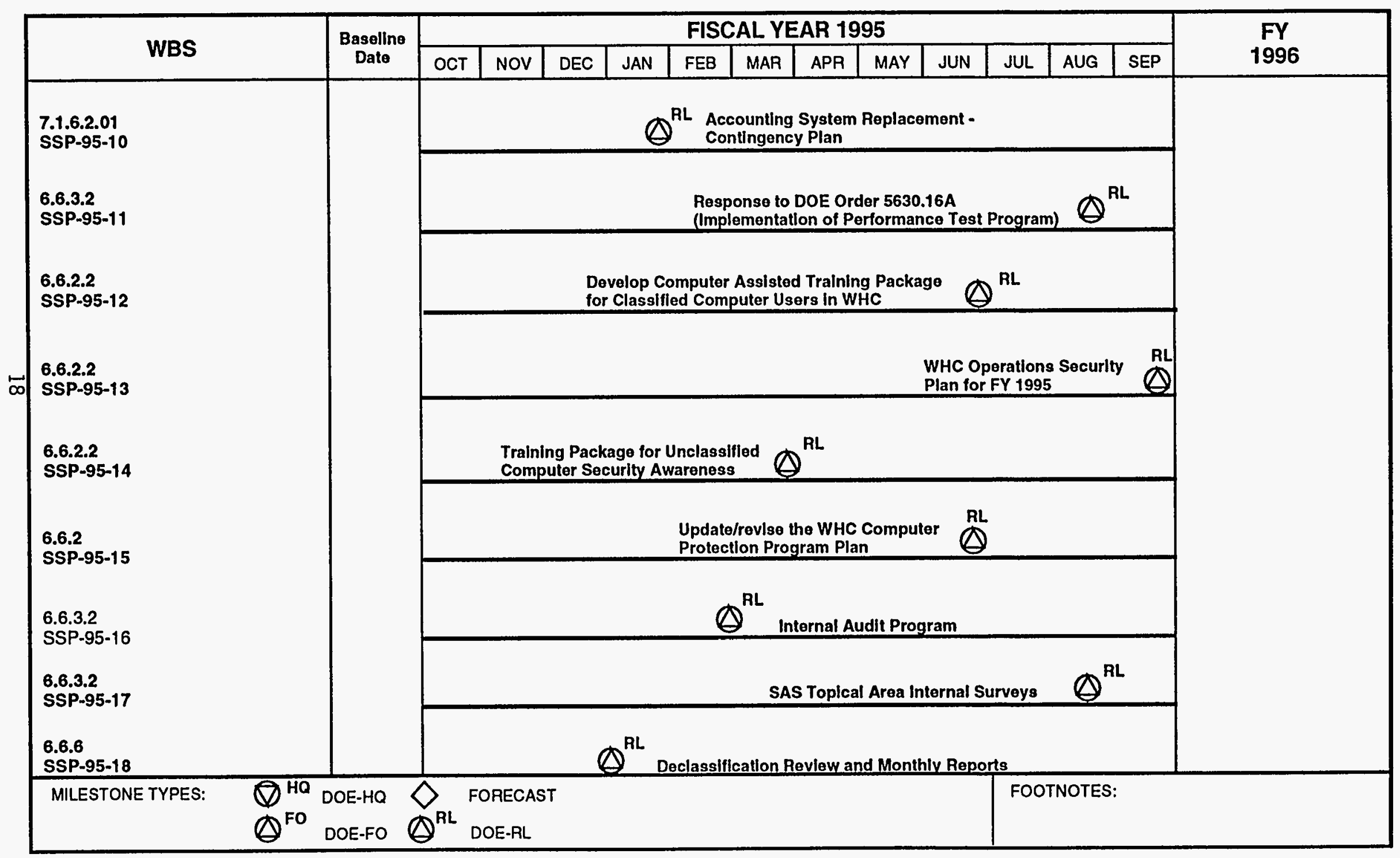




\begin{tabular}{|c|c|c|}
\hline SSPP & WESTINGHOUSE HANFORD COMPANY & OCTOBER 1994 \\
FY 1994 & 6.6 SAFEGUARDS AND SECURITY & \\
\hline
\end{tabular}

\section{MILESTONE SCHEDULE}

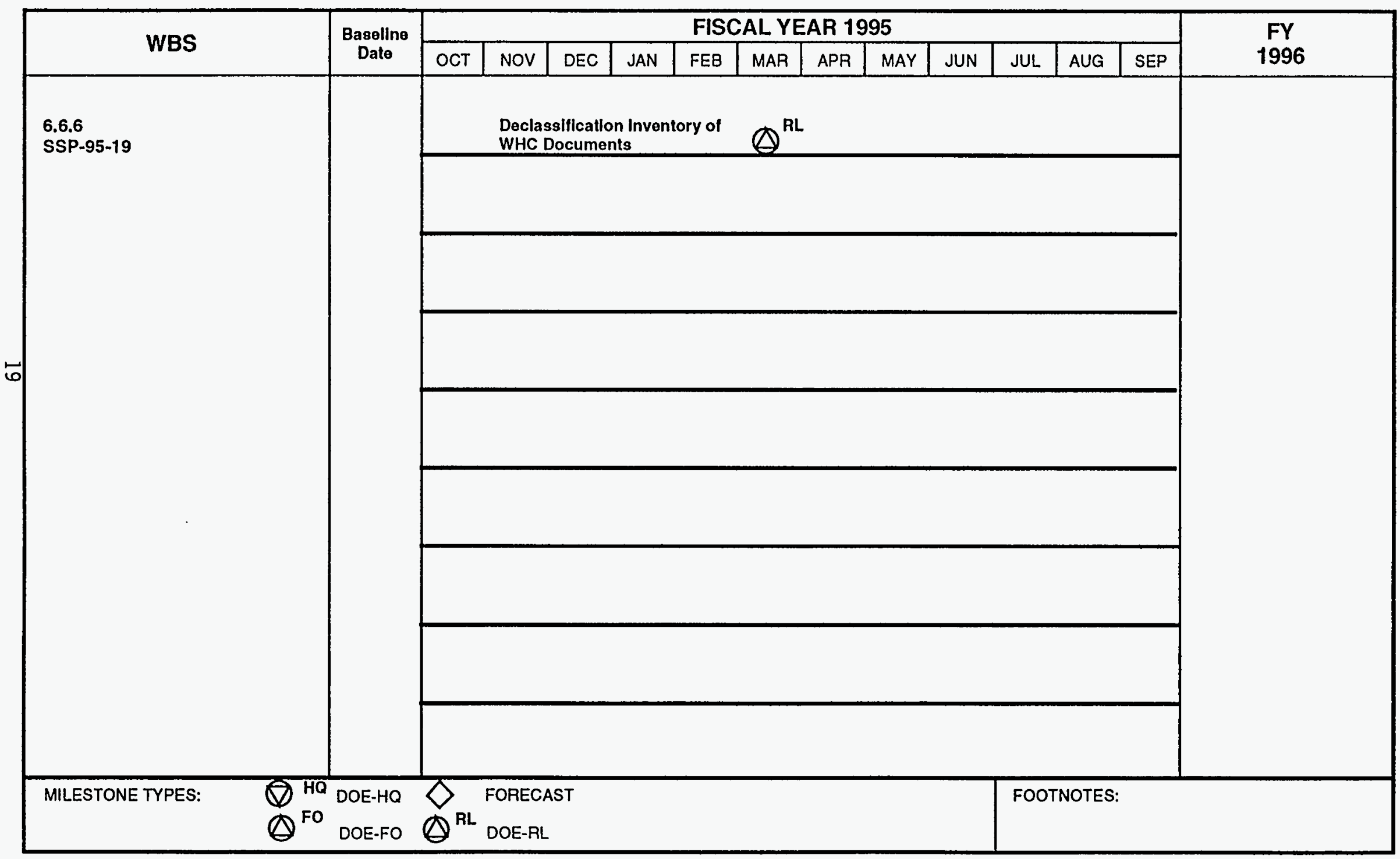




\begin{tabular}{|c|c|c|}
\hline & Westinghouse Hanford Company & FY 1995 SSPP \\
2.C.1 Cost Baseline & Safeguards and Security & Date Prepared: \\
by Program Element & 6.6 & AUGUST 31, 1994 \\
\hline
\end{tabular}

FY 1994 Cost Baseline (Dollars in Thousands)

\begin{tabular}{|l|l|c|}
\hline WBS \# & \multicolumn{1}{|c|}{ TitTe } & Total \$s \\
\hline 7.1 & $\begin{array}{l}\text { SAFEGUARDS AND SECURITY SUPPORT TO TRANSITION PROJECTS - PFP, SNM MANAGEMENT, } \\
\text { 300 AREA FUELS, PUREX. }\end{array}$ & $12,421.0$ \\
\hline 7.3 .1 & SAFEGUARDS AND SECURITY SUPPORT TO ADVANCED REACTOR. & $4,704.0$ \\
\hline 1.1 .1 & SAFEGUARDS AND SECURITY SUPPORT TO TWRS. & 755.0 \\
\hline 1.4 .1 & SAFEGUARDS AND SECURITY SUPPORT TO SPENT NUCLEAR FUELS. & $1,249.0$ \\
\hline 6.6 .1 & PATROL SUPPORT TO PNL. & 442.0 \\
\hline 6.6 .2 & SAFEGUARDS AND SECURITY SUPPORT TO GENERAL AND ADMINISTRATIVE (G\&A) ACTIVITIES. & $3,483.0$ \\
\hline 6.6 .3 & SAFEGUARDS AND SECURITY SUPPORT TO SITE WIDE (SWS) ACTIVITIES. & $12,180.0$ \\
\hline 6.6 .4 & LOCKSMITH SERVICES. & 771.0 \\
\hline 6.6 .5 & VEHICLE SAFETY PROGRAM. & 460.4 \\
\hline 6.6 .6 & WHC DECLASSIFICATION PROGRAM. & 91.2 \\
\hline 6.6 .7 & DOE SUPPORT SERVICES. & $3,038.0$ \\
\hline 6.6 .8 & SAFEGUARDS AND SECURITY DEPARTMENT OVERHEAD. & $9,894.0$ \\
\hline & & \\
\hline
\end{tabular}




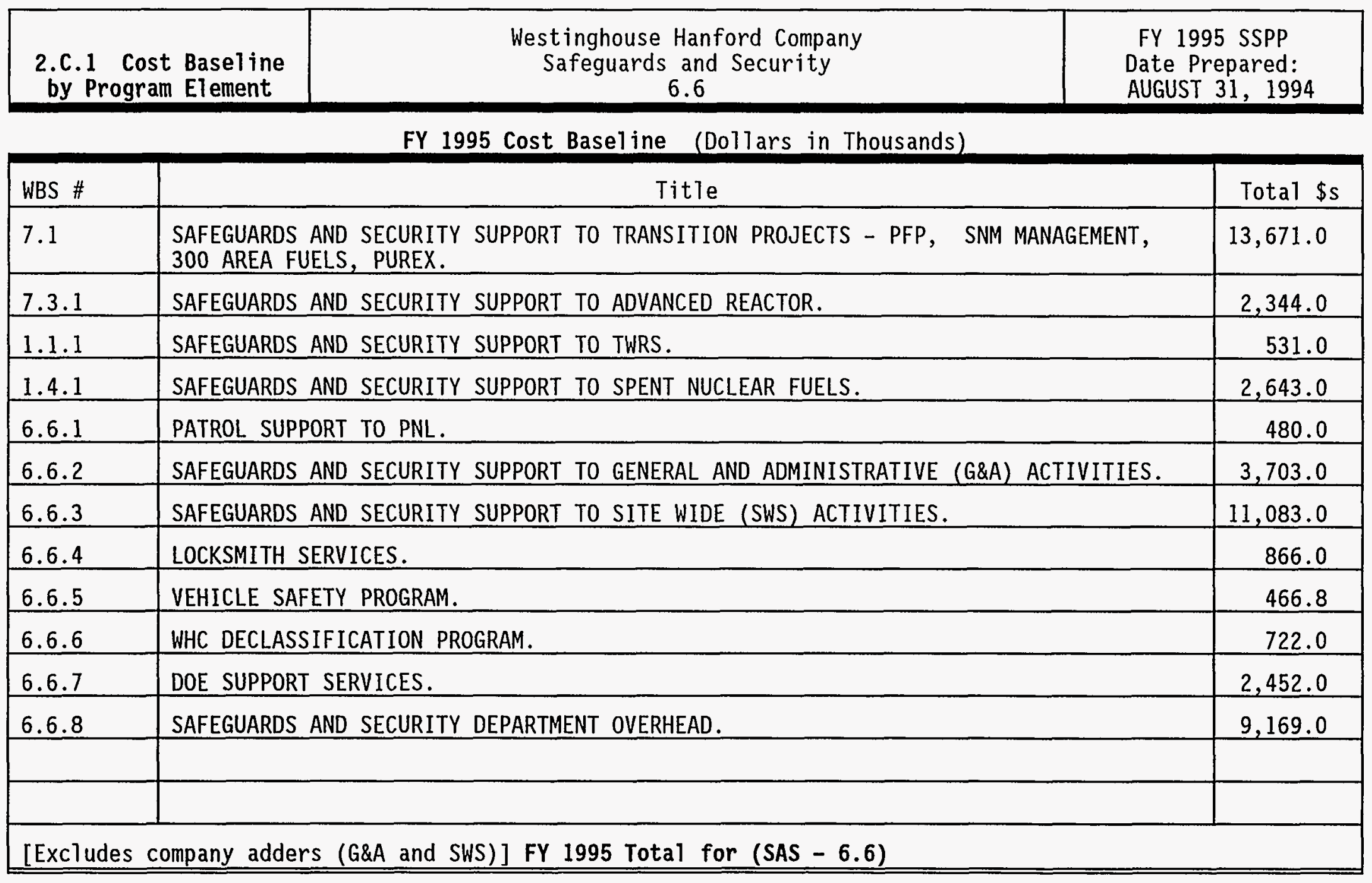




\begin{tabular}{|c|c|c|}
\hline & Westinghouse Hanford Company & FY 1995 SSPP \\
2.C.1 Cost Baseline & Safeguards and Security & Date Prepared: \\
by Program Element & 6.6 & AUGUST 31, 1994 \\
\hline
\end{tabular}

FY 1996 Cost Baseline (Dollars in Thousands)

\begin{tabular}{|c|c|c|}
\hline WBS \# & Title & Total \$s \\
\hline 7.1 & $\begin{array}{l}\text { SAFEGUARDS AND SECURITY SUPPORT TO TRANSITION PROJECTS - PFP, SNM MANAGEMENT, } \\
300 \text { AREA FUELS, PUREX. }\end{array}$ & $14,068.0$ \\
\hline 7.3 .1 & SAFEGUARDS AND SECURITY SUPPORT TO ADVANCED REACTOR. & $2,412.0$ \\
\hline 1.1 .1 & SAFEGUARDS AND SECURITY SUPPORT TO TWRS. & 567.0 \\
\hline 1.4 .1 & SAFEGUARDS AND SECURITY SUPPORT TO SPENT NUCLEAR FUELS. & $2,719.0$ \\
\hline 6.6 .1 & PATROL SUPPORT TO PNL. & 493.0 \\
\hline 6.6 .2 & SAFEGUARDS AND SECURITY SUPPORT TO GENERAL AND ADMINISTRATIVE (G\&A) ACTIVITIES. & $3,804.0$ \\
\hline 6.6 .3 & SAFEGUARDS AND SECURITY SUPPORT TO SITE WIDE (SWS) ACTIVITIES. & $11,406.0$ \\
\hline 6.6 .4 & LOCKSMITH SERVICES. & 891.0 \\
\hline 6.6 .5 & VEHICLE SAFETY PROGRAM. & 480.0 \\
\hline 6.6 .6 & WHC DECLASSIFICATION PROGRAM. & $1,184.0$ \\
\hline 6.6 .7 & DOE SUPPORT SERVICES. & $2,535.0$ \\
\hline 6.6 .8 & SAFEGUARDS AND SECURITY DEPARTMENT OVERHEAD. & $9,435.0$ \\
\hline & & \\
\hline Y & pany adders (G\&A and SWS)] FY 1996 & \\
\hline
\end{tabular}




\begin{tabular}{|c|c|c|}
\hline & Westinghouse Hanford Company & FY 1995 SSPP \\
2.C.1 Cost Baseline & Safeguards and Security & Date Prepared: \\
by Program Element & 6.6 & AUGUST 31, 1994 \\
\hline
\end{tabular}

FY 1997 Cost Baseline (Dollars in Thousands)

\begin{tabular}{|l|l|c|}
\hline WBS \# & \multicolumn{1}{|c|}{ TitTe } & Total $\$ S$ \\
\hline 7.1 & $\begin{array}{l}\text { SAFEGUARDS AND SECURITY SUPPORT TO TRANSITION PROJECTS - PFP, SNM MANAGEMENT, } \\
\text { 300 AREA FUELS, PUREX. }\end{array}$ & $14,475.0$ \\
\hline 7.3 .1 & SAFEGUARDS AND SECURITY SUPPORT TO ADVANCED REACTOR. & $2,482.0$ \\
\hline 1.1 .1 & SAFEGUARDS AND SECURITY SUPPORT TO TWRS. & 583.0 \\
\hline 1.4 .1 & SAFEGUARDS AND SECURITY SUPPORT TO SPENT NUCLEAR FUELS. & $2,799.0$ \\
\hline 6.6 .1 & PATROL SUPPORT TO PNL. & 508.0 \\
\hline 6.6 .2 & SAFEGUARDS AND SECURITY SUPPORT TO GENERAL AND ADMINISTRATIVE (G\&A) ACTIVITIES. & $3,914.0$ \\
\hline 6.6 .3 & SAFEGUARDS AND SECURITY SUPPORT TO SITE WIDE (SWS) ACTIVITIES. & $11,738.0$ \\
\hline 6.6 .4 & LOCKSMITH SERVICES. & 917.0 \\
\hline 6.6 .5 & VEHICLE SAFETY PROGRAM. & 494.0 \\
\hline 6.6 .6 & WHC DECLASSIFICATION PROGRAM. & $1,218.0$ \\
\hline 6.6 .7 & DOE SUPPORT SERVICES. & $2,609.0$ \\
\hline 6.6 .8 & SAFEGUARDS AND SECURITY DEPARTMENT OVERHEAD. & $9,709.0$ \\
\hline & & \\
\hline & & \\
\hline
\end{tabular}




\begin{tabular}{|c|c|c|c|}
\hline 2.C. 2 & $\begin{array}{l}\text { Cost Baseline by Funding } \\
\text { Source }\end{array}$ & $\begin{array}{c}\text { Westinghouse Hanford Company } \\
\text { Safeguards and Security } \\
6.6\end{array}$ & $\begin{array}{c}\text { FY } 1995 \\
\text { SSPP } \\
\text { AUGUST } 31,1994\end{array}$ \\
\hline
\end{tabular}

FY 1994 COST BASELINE (Dollars in Thousands)

\begin{tabular}{|c|c|c|c|c|c|c|c|}
\hline WBS \# & Title & Dept. $\mathrm{OH}$ & SWS/Oversight & SLP & $G \& A$ & Direct $\$$ & TOTAL \$s \\
\hline 7.1 & $\begin{array}{l}\text { SAS SUPPORT TO TRANSITION } \\
\text { PROJECTS. }\end{array}$ & & & & & $12,421.0$ & $12,421.0$ \\
\hline 7.3 .1 & $\begin{array}{l}\text { SAS SUPPORT TO ADVANCED } \\
\text { REACTOR. }\end{array}$ & & & & & $4,704.0$ & $4,704.0$ \\
\hline 1.1 .1 & SAS SUPPORT TO TWRS. & & & & & 755.0 & 755.0 \\
\hline 1.4 .1 & $\begin{array}{l}\text { SAS SUPPORT TO SPENT } \\
\text { NUCLEAR FUELS. }\end{array}$ & & & & & $1,249.0$ & $1,249.0$ \\
\hline 6.6 .1 & PATROL SUPPORT TO PNL. & & & & & 442.0 & 442.0 \\
\hline 6.6 .2 & $\begin{array}{l}\text { SAS SUPPORT TO G\&A } \\
\text { ACTIVITIES. }\end{array}$ & & & & $3,483.0$ & & $3,483.0$ \\
\hline 6.6 .3 & $\begin{array}{l}\text { SAS SUPPORT TO SWS } \\
\text { ACTIVITIES. }\end{array}$ & & $12,180.0$ & & & & $12,180.0$ \\
\hline 6.6 .4 & LOCKSMITH SERVICES. & & & 771.0 & & & 771.0 \\
\hline 6.6 .5 & VEHICLE SAFETY PROGRAM. & & 460.4 & & & & 460.4 \\
\hline 6.6 .6 & $\begin{array}{l}\text { WHC DECLASSIFICATION } \\
\text { PROGRAM. }\end{array}$ & & & & & 91.2 & 91.2 \\
\hline 6.6 .7 & DOE SUPPORT SERVICES. & & 632.0 & & & $2,406.0$ & $3,038.0$ \\
\hline 6.6 .8 & SAS DEPARTMENT OVERHEAD. & $9,894.0$ & & & & & \\
\hline & FY 1994 TOTALS & & $13,272.4$ & 771.0 & $3,483.0$ & $22,068.2$ & $39,594.6$ \\
\hline
\end{tabular}




\begin{tabular}{|c|c|c|c|c|c|c|c|}
\hline 2.C.2 & $\begin{array}{l}\text { Cost Baseline by Funding } \\
\text { Source }\end{array}$ & \multicolumn{4}{|c|}{$\begin{array}{c}\text { Westinghouse Hanford Company } \\
\text { Safeguards and Security } \\
6.6\end{array}$} & \multicolumn{2}{|c|}{$\begin{array}{l}\text { FY } 1995 \\
\text { SSPP } \\
\text { AUGUST } 31,1994\end{array}$} \\
\hline \multicolumn{8}{|c|}{ FY 1995 COST BASELINE (Dollars in Thousands) } \\
\hline WBS \# & Title & Dept. OH & SWS/Oversight & SLP & $G \& A$ & Direct $\$$ & TOTAL \$S \\
\hline 7.1 & $\begin{array}{l}\text { SAS SUPPORT TO TRANSITION } \\
\text { PROJECTS. }\end{array}$ & & & & & $13,671.0$ & $13,671.0$ \\
\hline 7.3 .1 & $\begin{array}{l}\text { SAS SUPPORT TO ADVANCED } \\
\text { REACTOR. }\end{array}$ & & & & & $2,344.0$ & $2,344.0$ \\
\hline 1.1 .1 & SAS SUPPORT TO TWRS. & & & & & 551.0 & 551.0 \\
\hline 1.4 .1 & $\begin{array}{l}\text { SAS SUPPORT TO SPENT } \\
\text { NUCLEAR FUELS. }\end{array}$ & & & & & $2,643.0$ & $2,643.0$ \\
\hline 6.6 .1 & PATROL SUPPORT TO PNL. & & & & & 480.0 & 480.0 \\
\hline 6.6 .2 & $\begin{array}{l}\text { SAS SUPPORT TO G\&A } \\
\text { ACTIVITIES. }\end{array}$ & & & & $3,703.0$ & & $3,703.0$ \\
\hline 6.6 .3 & $\begin{array}{l}\text { SAS SUPPORT TO SWS } \\
\text { ACTIVITIES. }\end{array}$ & & $11,083.0$ & & & & $11,083.0$ \\
\hline 6.6 .4 & LOCKSMITH SERVICES. & & & 866.0 & & & 866.0 \\
\hline 6.6 .5 & VEHICLE SAFETY PROGRAM. & & 466.8 & & & & 466.8 \\
\hline 6.6 .6 & $\begin{array}{l}\text { WHC DECLASSIFICATION } \\
\text { PROGRAM. }\end{array}$ & & & & & 722.0 & 722.0 \\
\hline 6.6 .7 & DOE SUPPORT SERVICES. & & 632.0 & & & $1,820.0$ & $2,452.0$ \\
\hline 6.6 .8 & SAS DEPARTMENT OVERHEAD. & $9,169.0$ & & & & & \\
\hline & FY 1995 TOTALS & & $12,181.8$ & 866.0 & $3,703.0$ & $22,231.0$ & $38,981.8$ \\
\hline
\end{tabular}




\begin{tabular}{|c|c|c|c|c|c|c|c|}
\hline 2.C.2 & $\begin{array}{l}\text { Cost Basel ine by Funding } \\
\text { Source }\end{array}$ & \multicolumn{4}{|c|}{$\begin{array}{c}\text { Westinghouse Hanford Company } \\
\text { Safeguards and Security } \\
6.6\end{array}$} & \multicolumn{2}{|c|}{$\begin{array}{l}\text { FY } 1995 \\
\text { SSPP } \\
\text { AUGUST } 31,1994\end{array}$} \\
\hline \multicolumn{8}{|c|}{ FY 1996 COST BASELINE (Dollars in Thousands) } \\
\hline WBS \# & Title & Dept. OH & SWS/Oversight & SLP & $G \& A$ & Direct $\$$ & TOTAL \$S \\
\hline 7.1 & $\begin{array}{l}\text { SAS SUPPORT TO TRANSITION } \\
\text { PROJECTS. }\end{array}$ & & & & & $14,068.0$ & $14,068.0$ \\
\hline 7.3 .1 & $\begin{array}{l}\text { SAS SUPPORT TO ADVANCED } \\
\text { REACTOR. }\end{array}$ & & & & & $2,412.0$ & $2,412.0$ \\
\hline 1.1 .1 & SAS SUPPORT TO TWRS. & & & & & 567.0 & 567.0 \\
\hline 1.4 .1 & $\begin{array}{l}\text { SAS SUPPORT TO SPENT } \\
\text { NUCLEAR FUELS. }\end{array}$ & & & & & $2,719.0$ & $2,719.0$ \\
\hline 6.6 .1 & PATROL SUPPORT TO PNL. & & & & & 493.0 & 493.0 \\
\hline 6.6 .2 & $\begin{array}{l}\text { SAS SUPPORT TO G\&A } \\
\text { ACTIVITIES. }\end{array}$ & & & & $3,804.0$ & & $3,804.0$ \\
\hline 6.6 .3 & $\begin{array}{l}\text { SAS SUPPORT TO SWS } \\
\text { ACTIVITIES. }\end{array}$ & & $11,406.0$ & & & & $11,406.0$ \\
\hline 6.6 .4 & LOCKSMITH SERVICES. & & & 891.0 & & & 891.0 \\
\hline 6.6 .5 & VEHICLE SAFETY PROGRAM. & & 480.0 & & & & 480.0 \\
\hline 6.6 .6 & $\begin{array}{l}\text { WHC DECLASSIF ICATION } \\
\text { PROGRAM. }\end{array}$ & & & & & $1,184.0$ & $1,184.0$ \\
\hline 6.6 .7 & DOE SUPPORT SERVICES. & & 650.0 & & & $1,885.0$ & $2,535.0$ \\
\hline 6.6 .8 & SAS DEPARTMENT OVERHEAD. & $9,435.0$ & & & & & \\
\hline & FY 1996 TOTALS & & $12,536.0$ & 891.0 & $3,804.0$ & $23,328.0$ & $40,559.0$ \\
\hline
\end{tabular}




\begin{tabular}{|c|c|c|c|c|c|c|c|}
\hline \multirow{3}{*}{$\begin{array}{l}2 . C .2 \\
\text { WBS \# } \\
\end{array}$} & \multirow{3}{*}{$\begin{array}{l}\begin{array}{l}\text { Cost Baseline by Funding } \\
\text { Source }\end{array} \\
\text { FY 199 } \\
\text { Title } \\
\end{array}$} & \multicolumn{4}{|c|}{$\begin{array}{c}\text { Westinghouse Hanford Company } \\
\text { Safeguards and Security } \\
6.6\end{array}$} & \multicolumn{2}{|c|}{$\begin{array}{l}\text { FY } 1995 \\
\text { SSPP } \\
\text { AUGUST 31, } 1994 \\
\end{array}$} \\
\hline & & \multirow{2}{*}{$\begin{array}{l}7 \text { COST BAS } \\
\text { Dept. } \mathrm{OH} \\
\end{array}$} & \multicolumn{3}{|c|}{ LINE (Dollars in Thousands) } & \multirow[b]{2}{*}{ Direct $\$$} & \multirow[b]{2}{*}{ TOTAL \$S } \\
\hline & & & SWS/Oversight & SLP & $G \& A$ & & \\
\hline 7.1 & $\begin{array}{l}\text { SAS SUPPORT TO TRANSITION } \\
\text { PROJECTS. }\end{array}$ & & & & & $14,475.0$ & $14,475.0$ \\
\hline 7.3 .1 & $\begin{array}{l}\text { SAS SUPPORT TO ADVANCED } \\
\text { REACTOR. }\end{array}$ & & & & & $2,482.0$ & $2,482.0$ \\
\hline 1.1 .1 & SAS SUPPORT TO TWRS. & & & & & 583.0 & 583.0 \\
\hline 1.4 .1 & $\begin{array}{l}\text { SAS SUPPORT TO SPENT } \\
\text { NUCLEAR FUELS. }\end{array}$ & & & & & $2,799.0$ & $2,799.0$ \\
\hline 6.6 .1 & PATROL SUPPORT TO PNL. & & & & & 508.0 & 508.0 \\
\hline 6.6 .2 & $\begin{array}{l}\text { SAS SUPPORT TO G\&A } \\
\text { ACTIVITIES. }\end{array}$ & & & & $3,914.0$ & & $3,914.0$ \\
\hline 6.6 .3 & $\begin{array}{l}\text { SAS SUPPORT TO SWS } \\
\text { ACTIVITIES. }\end{array}$ & & $11,738.0$ & & & & $11,738.0$ \\
\hline 6.6 .4 & LOCKSMITH SERVICES. & & & 917.0 & & & 917.0 \\
\hline 6.6 .5 & VEHICLE SAFETY PROGRAM. & & 494.0 & & & & 494.0 \\
\hline 6.6 .6 & $\begin{array}{l}\text { WHC DECLASSIFICATION } \\
\text { PROGRAM. }\end{array}$ & & & & & $1,218.0$ & $1,218.0$ \\
\hline 6.6 .7 & DOE SUPPORT SERVICES. & & 669.0 & & & $1,940.0$ & $2,609.0$ \\
\hline 6.6 .8 & SAS DEPARTMENT OVERHEAD. & $9,709.0$ & & & & & \\
\hline & FY 1997 TOTALS & & $12,901.0$ & 917.0 & $3,914.0$ & $24,005.0$ & $41,737.0$ \\
\hline
\end{tabular}




\section{C.3 STAFFING}

Westinghouse Hanford Company Safeguards and Security WBS 6.6
FY 1995

Site Support Program Plan August 31, 1994

\begin{tabular}{|c|c|c|c|c|c|c|c|c|}
\hline \multicolumn{5}{|c|}{ Full-Time Equivalent Staff by Job Description } & \multicolumn{4}{|c|}{$\begin{array}{l}\text { NOTE: Job Family Only After } \\
1996\end{array}$} \\
\hline JOB EAMATY & 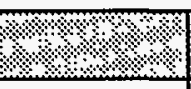 & (2.? & 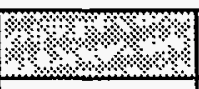 & ২. & 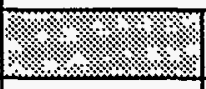 & $1+2+$ & (1) & $1+2$ \\
\hline Job category & 1994 & 1995 & 1996 & 1997 & 1998 & 1999 & 2000 & 2001 \\
\hline MGAMAGERS & ?. & 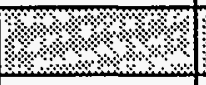 & ४४ & ? & (?. & 1. & 18 & $\sqrt{1+2}$ \\
\hline First Line & 39 & 39 & 39 & 39 & 39 & 39 & 39 & 39 \\
\hline General/executive & 4 & 4 & 4 & 4 & 4 & 4 & 4 & 4 \\
\hline \multicolumn{9}{|l|}{ Project/Program } \\
\hline other & 1 & 0 & 0 & 0 & 0 & 0 & 0 & 0 \\
\hline MANAGER TOTAI & 44 & 43 & 43 & 43 & 43 & 43 & 43 & 43 \\
\hline V. ENGMNAERRS & $1+.,+2$ & 2 & ४ै? & $1+2+2$ & (2. & 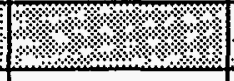 & 3. & 18 \\
\hline Chemical & 1 & 1 & 1 & 1 & 1 & 1 & 1 & 1 \\
\hline \multicolumn{9}{|l|}{ Civil } \\
\hline Computer & 1 & 1 & 1 & 1 & 1 & 1 & 1 & 1 \\
\hline Electrical & 2 & 2 & 2 & 2 & 2 & 2 & 2 & 2 \\
\hline \multicolumn{9}{|l|}{ Environmental } \\
\hline Industrial & 1 & 1 & 1 & 1 & 1 & 1 & 1 & 1 \\
\hline \multicolumn{9}{|l|}{ Mechanical } \\
\hline \multicolumn{9}{|l|}{ Nuclear } \\
\hline \multicolumn{9}{|l|}{ Petroleum/Mining } \\
\hline Plant & 7 & 7 & 7 & 7 & 7 & 7 & 7 & 7 \\
\hline \multicolumn{9}{|l|}{ Quality Control } \\
\hline \multicolumn{9}{|l|}{ Safety } \\
\hline Other & 14 & 14 & 14 & 14 & 14 & 14 & 14 & 14 \\
\hline
\end{tabular}




\section{C. 3 STAFFING}

Westinghouse Hanford Company Safeguards and security WBS 6.6
FY 1995

Site Support Program Plan August 31,1994

\begin{tabular}{|c|c|c|c|c|c|c|c|c|}
\hline \multicolumn{5}{|c|}{ Ful1-Time Equivalent staff by Job Description } & \multicolumn{4}{|c|}{$\begin{array}{l}\text { NOTE: Job Family Only After } \\
1996\end{array}$} \\
\hline 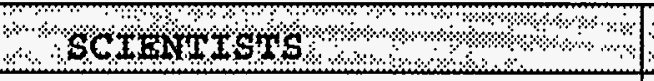 & \%का & \%० & +o. & कि: & \%०े & \% & 13 & $\sqrt{1 \%+\%}$ \\
\hline Chemists & 1 & 1 & 1 & 1 & 1 & 1 & 1 & 1 \\
\hline \multicolumn{9}{|l|}{ Environmental } \\
\hline \multicolumn{9}{|l|}{ Geologists } \\
\hline \multicolumn{9}{|l|}{ Life } \\
\hline \multicolumn{9}{|l|}{ Material } \\
\hline \multicolumn{9}{|l|}{ Mathematicians } \\
\hline \multicolumn{9}{|l|}{ Physicists } \\
\hline \multicolumn{9}{|l|}{ Social } \\
\hline Other & 1 & 1 & 1 & 1 & 1 & 1 & 1 & 1 \\
\hline 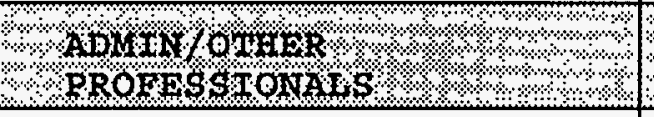 & \%ै. & +ै. & मै? & +ै. & अे+? & +. & $1+\%$ & $(1+3+$ \\
\hline \multicolumn{9}{|l|}{ Accountant/Auditor } \\
\hline \multicolumn{9}{|l|}{ Architect } \\
\hline \multicolumn{9}{|l|}{ Buyers/procurement } \\
\hline \multicolumn{9}{|l|}{ Communications } \\
\hline \multicolumn{9}{|l|}{ Compliance inspectors } \\
\hline \multicolumn{9}{|l|}{ Computer System Anal } \\
\hline Cost Est/Planner/Sch & 5 & 5 & 5 & 5 & 5 & 5 & 5 & 5 \\
\hline \multicolumn{9}{|l|}{ Health Physics } \\
\hline \multicolumn{9}{|l|}{ Industrial Hygiene } \\
\hline Lawyers & & & & & & & & \\
\hline
\end{tabular}




\section{C.3 STAFFING}

Westinghouse Hanford Company Safeguards and Security

WBS 6.6
FY 1995

Site Support Program Plan August 31, 1994

\begin{tabular}{|c|c|c|c|c|c|c|c|c|}
\hline \multicolumn{5}{|c|}{ Ful1-Time Equivalent staff by Job Description } & \multicolumn{4}{|c|}{$\begin{array}{l}\text { NOTE: Job Family Only After } \\
1996\end{array}$} \\
\hline $\begin{array}{l}\text { Personnel/Labor } \\
\text { Relations }\end{array}$ & & & & & & & & \\
\hline Physicians & & & & & & & & \\
\hline Physician Assis/Nurse & & & & & & & & \\
\hline Safeguard \& Security & 86 & 82 & 82 & 82 & 82 & 82 & 82 & 82 \\
\hline Tech Writers \& Edit & & & & & & & & \\
\hline Trainers & 1 & 1 & $I$ & 1 & 1 & 1 & 1 & 1 \\
\hline Other & 6 & 6 & 6 & 6 & 6 & 6 & 6 & 6 \\
\hline 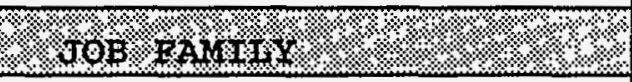 & $1+2.8$ & 18 (2.? & (४). & ?.? & ?.+. & $18 .+2$ & (2. & 1 \\
\hline Job Category & & & & & & & & \\
\hline PROFESSIONAL TOTAL & 126 & 122 & 122 & 122 & 122 & 122 & 122 & 122 \\
\hline 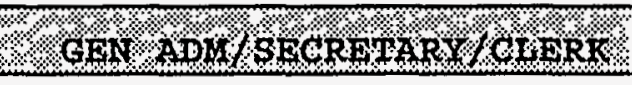 & $1+2.8$ & $18+2$. & 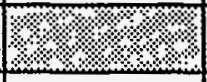 & $3.1 \%$ & 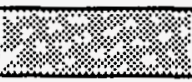 & 18 (2. & $1+1 .+2$ & 18.2 .8$. \\
\hline Admin Assistants & & & & & & & & \\
\hline Office Clerks (Gen) & 10 & 10 & 10 & 10 & 10 & 10 & 10 & 10 \\
\hline Office Clerks (Special) & 23 & 19 & 19 & 19 & 19 & 19 & 19 & 19 \\
\hline Secretaries & 16 & 15 & 15 & 15 & 15 & 15 & 15 & 15 \\
\hline Typist/Word Process & & & & & & & & \\
\hline Other & & & & & & & & \\
\hline 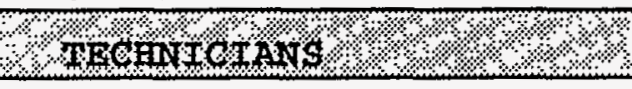 & ?ै. & (?) & 2.े. & \%ै\% & $\frac{1}{2}+2$. & (2. & 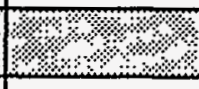 & $1 .+2$. \\
\hline Computer Oper/Coder & 1 & 1 & 1 & 1 & 1 & 1 & 1 & 1 \\
\hline Drafters & & & & & & & & \\
\hline Engineers/Tech & & & & & & & & \\
\hline
\end{tabular}




\section{C. 3 STAFFING}

Westinghouse Hanford Company

Safeguards and Security

WBS 6.6
FY 1995

Site Support Program Plan August 31, 1994

\begin{tabular}{|c|c|c|c|c|c|c|c|c|}
\hline \multicolumn{5}{|c|}{ Ful1-Time Equivalent Staff by Job Description } & \multicolumn{4}{|c|}{$\begin{array}{l}\text { NOTE: Job Family only After } \\
\text { 1996 }\end{array}$} \\
\hline Envir. Sci Technicians & & & & & & & & \\
\hline Health Phys. Tech & & & & & & & & \\
\hline Indus. Saf/Health Tech & & & & & & & & \\
\hline Instru/Control Tech & & & & & & & & \\
\hline Lab. Technicians & & & & & & & & \\
\hline Media Technicians & & & & & & & & \\
\hline Survey/Map Tech & & & & & & & & \\
\hline Other & & & & & & & & \\
\hline NON-EXEMPT TOTAL & 50 & 45 & 45 & 45 & 45 & 45 & 45 & 45 \\
\hline CoRAGMS & अै। & मि, & ४ै। & ४ै०े। & ४ै+ & 1 & 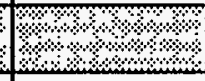 & 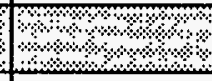 \\
\hline Carpenters & & & & & & & & \\
\hline Electricians & 6 & 6 & 6 & 6 & 6 & 6 & 6 & 6 \\
\hline HVAC & & & & & & & & \\
\hline Machinists & & & & & & & & \\
\hline Masons & & & & & & & & \\
\hline Millwrights & & & & & & & & \\
\hline Painters & & & & & & & & \\
\hline Plumbers/Pipefitters & & & & & & & & \\
\hline Struct/Metal Workers & & & & & & & & \\
\hline Vehic./Mob Equip Mech & & & & & & & & \\
\hline Welders & & & & & & & & \\
\hline Other & 13 & 13 & 13 & 13 & 13 & 13 & 13 & 13 \\
\hline
\end{tabular}




\section{C.3 STAFFING}

Westinghouse Hanford Company Safeguards and Security

WBS 6.6
FY 1995

Site Support Program Plan August 31,1994

\begin{tabular}{|c|c|c|c|c|c|c|c|c|}
\hline \multicolumn{5}{|c|}{ Ful1-Time Equivalent Staff by Job Description } & \multicolumn{4}{|c|}{$\begin{array}{l}\text { NOTE: Job Family Only After } \\
1996\end{array}$} \\
\hline 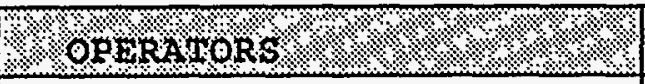 & $18+8$ & $1 \%+2$ & 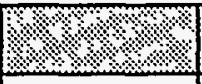 & ?. & 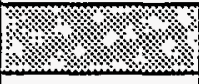 & 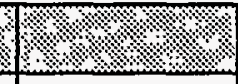 & $18+2$ & $18+2$ \\
\hline \multicolumn{9}{|l|}{ Chemical System } \\
\hline \multicolumn{9}{|l|}{ Drillers } \\
\hline \multicolumn{9}{|l|}{ Lt. Vehicle Drivers } \\
\hline \multicolumn{9}{|l|}{ Material Moving Equip } \\
\hline \multicolumn{9}{|l|}{ Nuclear Plant } \\
\hline \multicolumn{9}{|l|}{ Utilities Waste Proces } \\
\hline \multicolumn{9}{|l|}{ Other } \\
\hline r. & \%ै. & $12+\%$ & 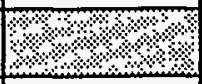 & 3 & (2. & 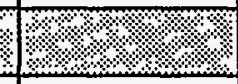 & 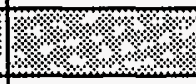 & 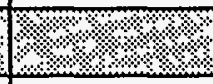 \\
\hline \multicolumn{9}{|l|}{ Firefighters } \\
\hline \multicolumn{9}{|l|}{ Food Service } \\
\hline \multicolumn{9}{|l|}{ Hand/Help Lab Gen } \\
\hline \multicolumn{9}{|l|}{ Hand/Help Lab Spec } \\
\hline \multicolumn{9}{|l|}{ Janitors/Cleaners } \\
\hline \multicolumn{9}{|l|}{ Laundry Workers } \\
\hline Security Guards & 146 & 146 & 146 & 146 & 146 & 146 & 146 & 146 \\
\hline \multicolumn{9}{|l|}{ Other } \\
\hline BARGAINING UNIT TOTAL & 165 & 165 & 165 & 165 & 165 & 165 & 165 & 165 \\
\hline SAS TOTAL & 385 & 375 & 375 & 375 & 375 & 375 & 375 & 375 \\
\hline
\end{tabular}


SAFEGUARDS AND SECURTY

FY 1995 BASEINE LOG

(Fonly Berdened sin 0006)

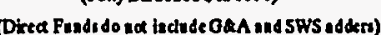

\begin{tabular}{|c|c|c|c|c|c|c|c|c|c|c|c|c|c|c|}
\hline FY 1995 & SWS & G\&A & PFP & $\begin{array}{c}\text { ADV } \\
\text { REACTOR }\end{array}$ & TWRS & SNF & $\begin{array}{l}\text { SNM } \\
\text { MNGMT }\end{array}$ & $300-A$ & PUREX & PNL & $\begin{array}{l}\text { LOCK } \\
\text { SMITHS }\end{array}$ & DEQLASS & $\begin{array}{l}\text { DOE } \\
\text { SUPPORT } \\
\text { SERVICES }\end{array}$ & TOTAL \\
\hline SSPP BASEINE & 11,549.8 & $3,703.0$ & $12,205.0$ & $2,344.0$ & 551.0 & $2,643.0$ & $1,165.0$ & 231.0 & 70.0 & 480.0 & 866.0 & 7220 & $2,452.0$ & $38,981.8$ \\
\hline NON SAS & $(1,466,8)$ & 0.0 & 0.0 & 0.0 & $(200.0)$ & 0.0 & 0.0 & 0.0 & 0.0 & $(480.0)$ & $(866.0)$ & $(7220)$ & $(1,364,3)$ & $(5,099.1)$ \\
\hline FY 1995 CAOSSCUT & $\begin{array}{c}10,083.0 \\
\text { 1) }\end{array}$ & $3,708.0$ & $12,205.0$ & $2,344.0$ & 2) 351.0 & $2,643.0$ & $1,165,0$ & 231.0 & 70.0 & 0.0 & 0.0 & 0.0 & $1,087.7$ & $33,882.7$ \\
\hline
\end{tabular}

NON SAS identified workscopo not included in SAS Crosscut. Specfically the following notes are provided.

1) $(1,000.0)$ - Yakima \& Wyo Barricado (10 FTEs)

$(466.8)$ - Vohicle Safoty
$(1,466.8)$ - Total NON SAS

2) (200.0) - Hand Geomotry

w3) DOE Support Senvices Baseline ls:

$1,820.0$ - Offiste Basoline (\$2221.0 - \$401.0 G\&AVWS

632.0 - BCSO WHC PORTION) after reduction for G\&A \& 20\% (PNL PORTION) - $(\$ 632.0$ WHC; $\$ 190.0$ PNL and $\$ 128.0$ G\&A $=\$ 950.0)$

DOE Support Sorvices NON SAS lo:

1,364.3 - Offilte Basollne loss DOE - RL Support CAP 1 TL420 (555.9 - G\&AVSS 100.2 = 455.7) $(1820$ - 455.7 = 1,364.3)

DOE Support Services FY95 Crosscut ls:

1,087.7 - RL Support CAP $17 L 420+$ BCSO (from above) $(455.7+632=1,087.7)$

4) The SWS Baseline is comprised of IMDBOA: $\$ 11083,0$ and Vehicle Sufety: $\$ 466.8$. 
WHC-SP-1123

WBS CODES FOR SSPP

SAFEGUARDS AND SECURITY FY 1995

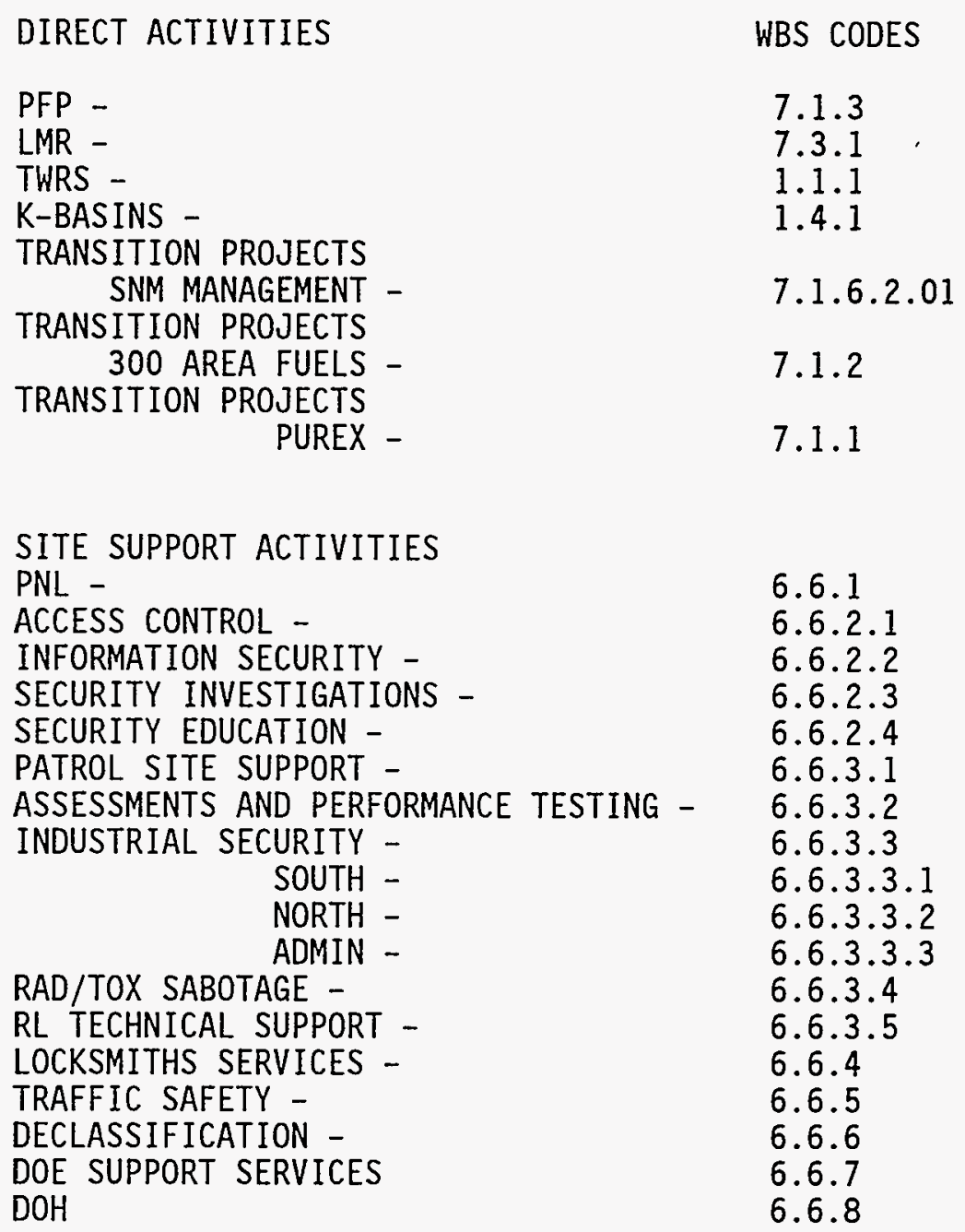


Work

Breakdown

Structure

Dictionary

Cost Account

$1 \mathrm{~K} 6 \mathrm{~F} \& 1 \mathrm{~K} 6 \mathrm{C}$

SMS WBS

7.1.3

CAM Review/Approval C.W. WALTON

SMS Program Manager Review/Approval C.W. WALTON

Financlal Manager Review/Approval L.C. BRANDT

Responsible Analyst L.V. JONES

OSBRB Review/Approval

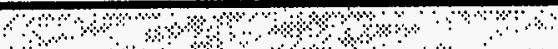

FULL-TIME EQUIVALENTS (FTES)

. Organizational - Exempt

- Organizational - Nonexempt

. Organizational - Bargaining

Total Organizational FTEs

Support FTEs

TOTALFTES

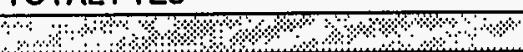

COST ELEMENTS

. Labor - Regular

. Labor - Overtime

0 Total Labor

1 Materials

2 Purchased Services

3 Other Hanford

4 Site Services

5 Internal Charges

6 IRM Support

7 Overheads

G\&A / SWS

TOTALDOLLARS

SMS Titlo

Budget
Westinghouse Hanford Company SAFEGUARDS AND SECURITY

Part I - Summary

(Dallars in 000's)

Cost Account Titlo

SAFEGUARDS AND SECURITY SUPPORT TO PFP

SAFEGUARDS AND SECURITY

\begin{tabular}{l|l}
\hline L.C. BRA \\
\hline \\
\hline \\
\hline \\
\hline \\
\hline \\
\hline \\
\hline
\end{tabular}

Fiscal Year Spending

Forecast (FYSF)

09

Dat
Dat
Dat
Dat
Dat

Date
Date
Date
Date
Date

FY 1995

FY 1995 SSPP

Rev. \# 0

G\&A

SWS

\begin{tabular}{ll}
\hline OST \\
\hline DOH
\end{tabular}

DOH

MGT PRO

POOL

24-Sep-94 DIRECT XX

Annualized Rate

(For Organizational Overhead and

Rated Service Pool Use Only) FY 1994 Rate

$50 \%$

FY 1995

Target

\begin{tabular}{|c|c|}
\hline Request & $\begin{array}{c}\text { Approved } \\
\text { Baseline }\end{array}$ \\
\hline 46.4 & \\
\hline 5.8 & \\
\hline 72.2 & \\
\hline 124.4 & \\
\hline 4.6 & \\
\hline 129 & \\
\hline
\end{tabular}
FY 1995 Rate Request

FY 1995 Approved Rate

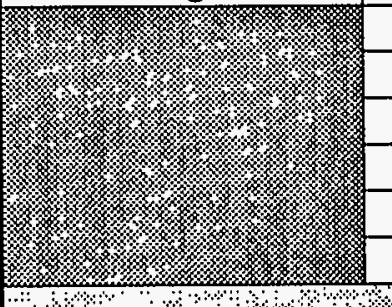

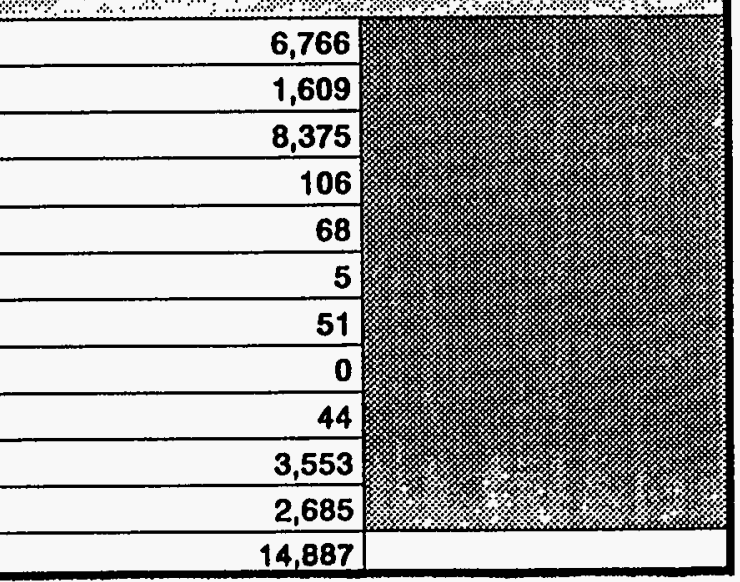




\begin{tabular}{|c|c|c|c|c|c|}
\hline \multirow{5}{*}{$\begin{array}{l}\text { Work } \\
\text { Breakdown } \\
\text { Structure } \\
\text { Dictionary }\end{array}$} & \multirow{5}{*}{\multicolumn{3}{|c|}{$\begin{array}{c}\text { Westinghouse Hanford Company } \\
\text { SAFEGUARDS \& SECURITY } \\
\text { Part I - Summary } \\
\text { (Dollars in 000's) }\end{array}$}} & \multirow{7}{*}{$\begin{array}{l}\text { FY } 1995 \text { SSPP } \\
\text { Rev. \# } 0\end{array}$} & \multirow{2}{*}{\begin{tabular}{|l|} 
Funding Source: \\
G\&A \\
\end{tabular}} \\
\hline & & & & & \\
\hline & & & & & sws \\
\hline & & & & & OST \\
\hline & & & & & $\mathrm{DOH}$ \\
\hline Cost Account & Cost Account Title & & & & $\mathrm{POOL}$ \\
\hline $1 K 6 F 3 / 4 / 5 \& 6$ & SAFEGUARDS AND SECU & URITY & & & DIRECT $X X$ \\
\hline $\begin{array}{l}\text { SMS WBS } \\
7.1 .3 \\
\end{array}$ & $\begin{array}{l}\text { SMS Titlo } \\
\text { NORTHERN SECURITY O }\end{array}$ & OPS SUPPORT - VAULT \& & \& BAL PLANT & $\begin{array}{r}\text { Annualiz } \\
\text { (For Organizatlona }\end{array}$ & $\begin{array}{l}\text { od Rate } \\
\text { l Overhead and }\end{array}$ \\
\hline CAM Review/Approval & C.W. WALTON & & Date & Rated Service Po & ol Use Only) \\
\hline SMS Program Manager Revlew/Approve & & C.W. WALTON & Date & FY 1994 Rate & FY 1995 Rate Request \\
\hline Financial Manager Review/Approval & & L.C. BRANDT & Date & $50 \%$ & $42 \%$ \\
\hline Responsible Analyst & & L.V. JONES & Date & FY 1995 Target Rate & FY 1995 Approved Rate \\
\hline OSBRB Review/Approval & & & Date & $42 \%$ & \\
\hline 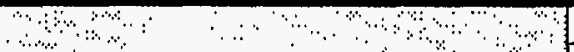 & FY19: & 994 & & FY 1995 & \\
\hline FULL-TIME EQUIVALENTS (FTES) & BUDGET & $\begin{array}{c}\text { Fiscal Year Spending } \\
\text { Forecast (FYSF) }\end{array}$ & Target & Request & $\begin{array}{l}\text { Approved } \\
\text { Baseline }\end{array}$ \\
\hline . Organizational - Exempt & 6.9 & & & 6.6 & \\
\hline . Organizational - Nonexempt & 1.5 & & & 1.5 & \\
\hline . Organizational - Bargaining & 6.3 & & & 6.5 & \\
\hline Total Organizational FTEs & 14.7 & & & 14.6 & \\
\hline Support FTEs & 1.3 & & & 1.3 & \\
\hline TOTALFTES & 16 & & & 15.9 & \\
\hline 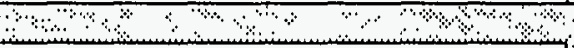 & िद & & & 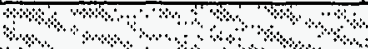 & \\
\hline COST ELEMENTS & 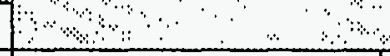 & & & ४ & \\
\hline . Labor - Regular & 1,072 & 860 & & 976 & \\
\hline . Labor - Overtime & & & & 75 & \\
\hline 0 Total Labor & 1,072 & 860 & & 1,051 & \\
\hline 1 Materials & 80 & 79 & & 80 & \\
\hline 2 Purchased Senvices & 15 & 20 & & 20 & \\
\hline 3 Other Hanford & 35 & 4 & & 5 & \\
\hline 4 Site Services & 20 & 40 & & 40 & \\
\hline 5 Internal Charges & & & & & \\
\hline 6 IRM Support & 10 & 15 & & 15 & \\
\hline 7 Overheads & 617 & 410 & & 441 & \\
\hline G\&ASWS & 401 & 372 & & 363 & \\
\hline TOTAL DOLLARS & 2,250 & 1,800 & & 2,015 & \\
\hline
\end{tabular}




\section{Work Breakdown Structure Dictionary}

Westinghouse Hanford Company Safeguards and Security Part II - Element Definition
FY 1995 SSSP

Revision \#0

WBS ELEMENT CODE: $\quad 7.1 .3$ TITLE: NORTHERN SECURITY OPERATIONS SUPPORT TO PFP (SUMMARY)

\section{ELEMENT TASK DESCRIPTION}

COST CONTENT - Develop and administer security support for the security systems, preventive maintenance and spare parts program, Projects coordination, physical security issues, key control, and security education.

TECHNICAL CONTENT - According to applicable DOE Orders and Company Directives, provide specialized physical security protection guidance, security educational training, security alarm systems maintenance and testing, software and hardware engineering, and key accountability control.

OBJECTIVES - Provide appropriate staffing to support PFP site security requirements; adjust organizational goals to meet mission changes; perform maintenance and engineering to retain safe and cost effective $a 7$ arm and assessment systems through remedial and preventive maintenance and system enhancement programs; provide specialized security engineering for project designs, planning, overview support and approvals for the security systems, major Projects and their related facilities; and direct or approve plant security policy changes.

ASSUMPTIONS / CONSTRAINTS - PFP will remain operational pending approval of PRF and RMC EIS documentation submittals. $\mathrm{Planning}$ and direction for conversion of vault-type storage rooms to vaults will proceed with a three-plus year completion deadline; minor but no further significant SNM storage relocations will occur. The existing Protected Area and interior sensor systems will be retained. Replacement of the operating alarm computer system will be planned and enacted by FY96. NSO will undertake to replace the Isolation Area's microwave sensor system. / Budget planning constraints and complexities will require greater staff support and documentation.

\section{MILESTONES - None}

DELIVERABLES - Greater than 98\% Alarm Monitoring Computer System uptime per month. Greater than 98\% completion of Plant Functional Sensor Testing per month. Greater than $98 \%$ completion of NSO Sensor Sensitivity Testing per six month period. Greater than $90 \%$ completion of required monthly security system PMs. Meet $100 \%$ of all RL audit ECDs. Support PFP mi iestone to complete Plant required VA driven security upgrades to reduce Patrol Posts by two by September 1995. Provide a comprehensive total physical security program to support the PFP Plant, including security maintenance, software support, engineering, systems testing, key control, and security education. 


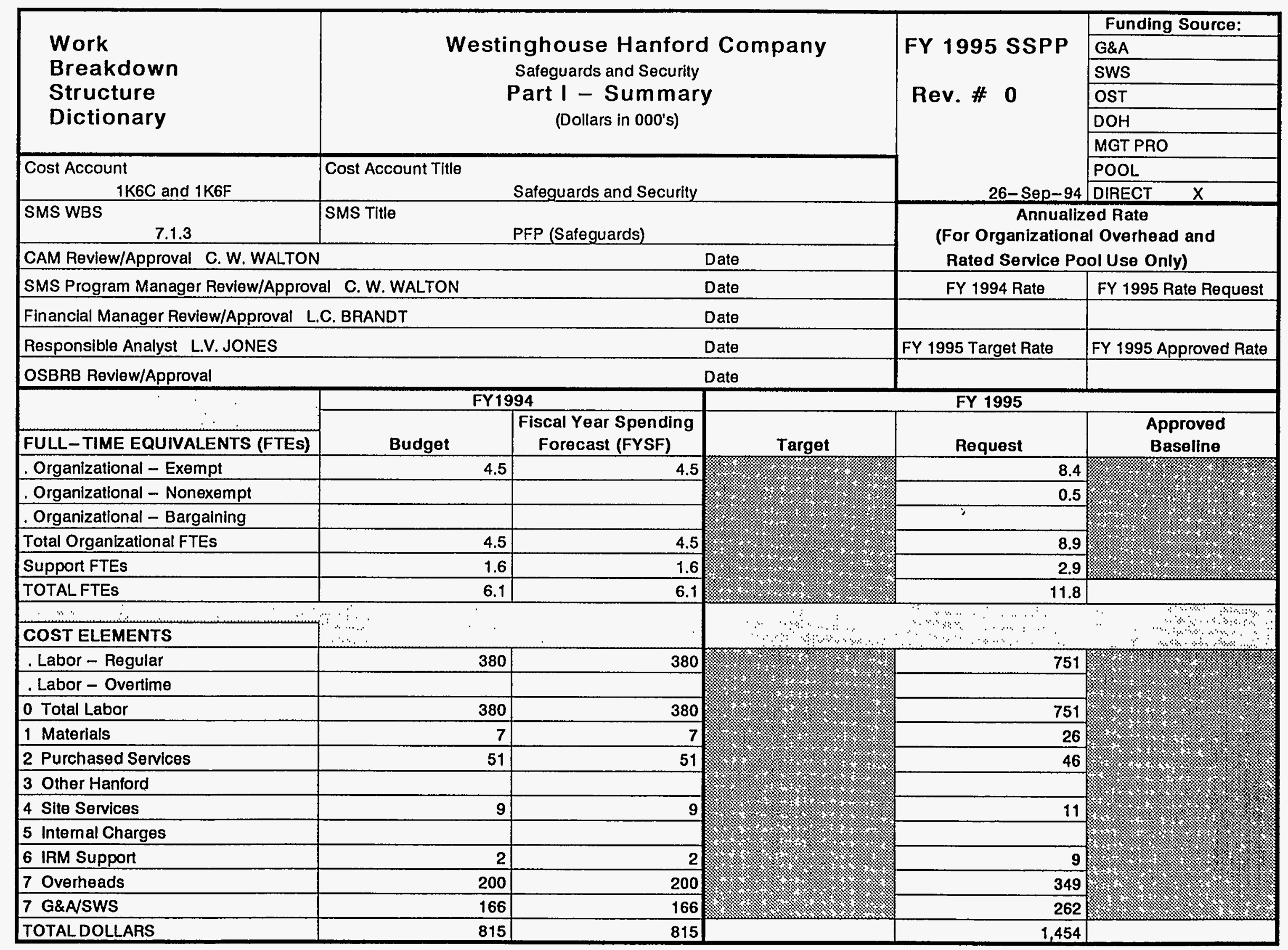




\begin{tabular}{|l|c|c|}
\hline \multicolumn{1}{|c|}{$\begin{array}{c}1 \mathrm{KGC} \text { and } 1 \mathrm{~K} 6 \mathrm{~F} \\
\text { cosT ACcouNT }\end{array}$} & Westinghouse Hanford Company & FY 1995 SSPP \\
\hline $\begin{array}{l}\text { Work Breakdown } \\
\text { Structure } \\
\text { Dictionary }\end{array}$ & Safeguards and Security & Revision \# 0 \\
\hline
\end{tabular}

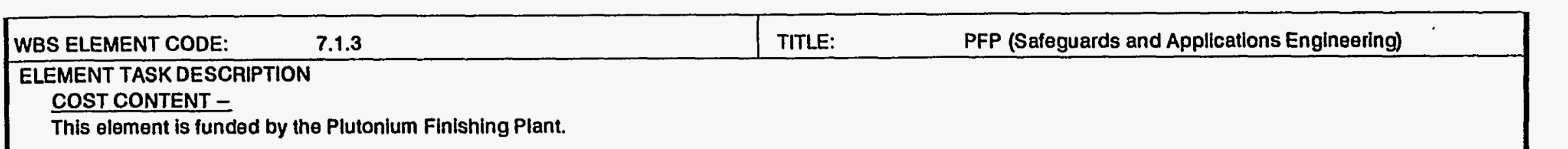

\section{TECHNICAL CONTENT -}

This element is responsible for developing, maintaining, and implementing policies and procedures governing the use, control and accountability of nuclear materials in conformance with DOE orders. Regulatory drivers that impact the element are DOE 5633.3A, "Control and Accountability of Nuclear Materials", DOE 5633.4, "Nuclear Materials Transactions: Documentation and Reporting", DOE 5633.5, "Nuclear Materlals Reponting and Data Submission Procedures", and RLID 5633.3A, "Control and Accountability of Nuclear Materials at Richland Operations Office". The ABC budget process will also be supported under this cost account.

\section{OBJECTIVES -}

The element will control and account for WHC nuclear materials in a manner that meets the requirements of federal and state regulatlons, DOE Orders, safety and environmental compliance requirements, and other WHC company policies. In addition, the element will proactively identify MC\&A Issues, develop workable solutions, and follow through on implementation of solutions.

\section{ASSUMPTIONS/CONSTRAINTS -}

SAS systems for nuclear material accounting at the PFP will have high operational risks by FY 1996. Compensatory measures will be developed and replacement planning will proceed consistent with available resources.

Some Hanford SNM will be intilally placed under IAEA inspection in FY 1995. Additional SNM will increasingly be placed under IAEA inspection through FY 2000

\section{MILESTONES -}

Provide support to "Replacement Analysis for Safeguards and Security Systems of Hanford Protected Areas" as negotlated with PFP project manager. Level of effort through September 1995.

Prepare and submit required IAEA Design Information Questlonnaire (DIQ) by January 15, 1995.

IAEA Initial inspection of PFP Vault Room 3 by February $1,1995$.

Respond to RL requests for support to future international programs; i.e., bllateral agreements and expansion of IAEA inspections as required. Level of effort through September 1995.

\section{DELIVERABLES -}

- Monthly and quarterly nuclear materlal reports for RL Safeguards and AL Programs

- MC\&A training records Including course completlon rosters, custodian authorizations, OJT checklists, and exams

- NMMSS transection and inventory data

- Physical inventory records including schedules, Inventory plans, releases to resume actlvities, signed PRE-416 reports, and RL-430 certificatlon forms

- RL Survey questionnaire

- Quarterly report from historical Inventory difference database

- TID records on applicatlons, removals, locations and inventory 


\section{Work \\ Breakdown \\ Structure \\ Dictionary}

\section{Cost Account}

$\mathrm{K} 6 \mathrm{C} 6$

SMS WBS

7.1.3

CAM Review/Approval

SMS Program Manager Review/Approval

Financial Manager Review/Approval

Responsible Analyst

OSBRB Review/Approval

\section{FULL-TIME EQUIVALENTS (FTES)}

Organizational - Exempt

Organizational - Nonexempt

Organizational - Bargaining

Total Organizational FTEs

Support FTEs

TOTALFTES

\section{COST ELEMENTS}

\section{. Labor - Regular}

. Labor - Overtime

0 Total Labor

1 Materials

2 Purchased Services

3 Other Hanford

4 Site Services

5 Internal Charges

6 IRM Support

7 Overheads

G\&ASWS

TOTAL DOLLARS
Westinghouse Hanford Company

SAFEGUARDS \& SECURITY

Part I - Summary

(Dollars in 000's)

Cost Account Title

SAS

SMS Title

PFP - SAS SUPPORT TO IAEA - APPLICATIONS ENGINEERING C.W. WALTON

IAEA - APPLICATIONS ENGINEE
Date

C.W. WALTON

L.C. BRANDT

L.V. JONES

Date

Date

Date

Date

\begin{tabular}{|r|r|}
\hline \multicolumn{3}{|c|}{ FY1994 } \\
\hline Budget & $\begin{array}{l}\text { Fiscal Year Spending } \\
\text { Forecast (FYSF) }\end{array}$ \\
\hline 0 & 0 \\
\hline 0 & 0 \\
\hline 0 & 0 \\
\hline 0 & 0 \\
\hline
\end{tabular}

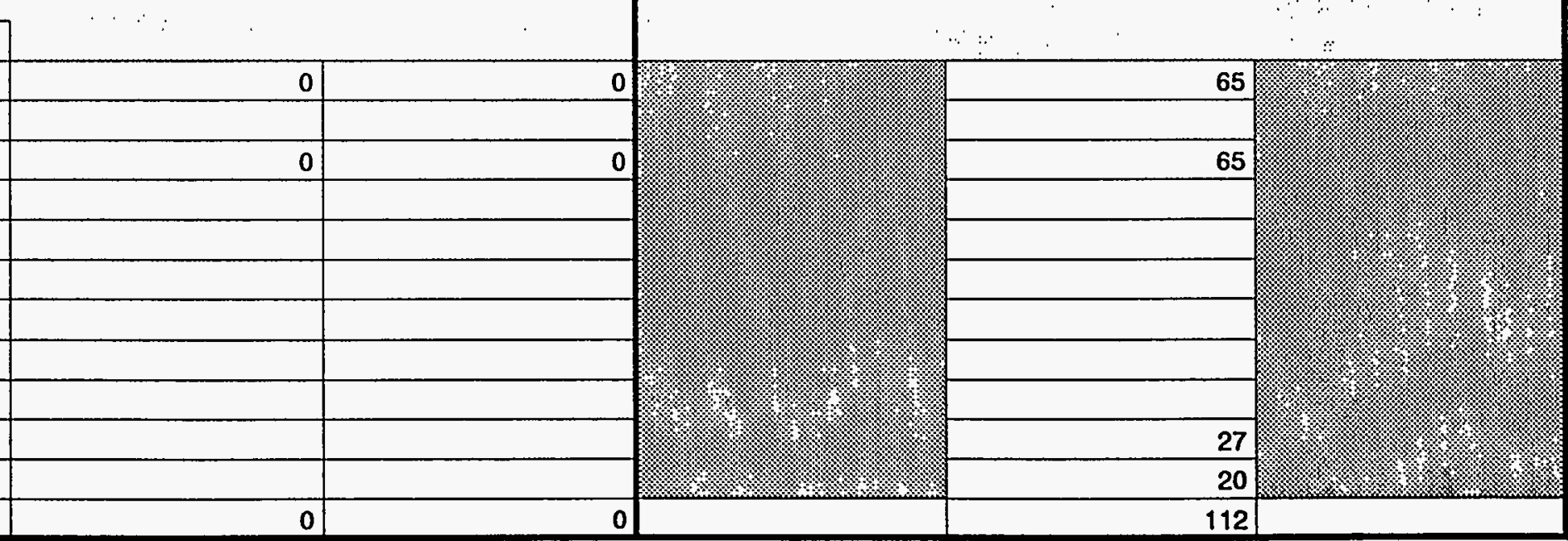

FY 1995 SSPP

Rev. \# 0

\section{G\&A}

SWS

OST

DOH

MGT PRO

POOL

26-Sep-94 DIRECT $X$

Annualized Rate

(For Organizational Overhead and

Rated Service Pool Use Only)

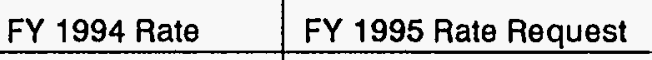

$50 \%$

FY 1995 Target Rate

FY 1995 Approved Rate

$42 \%$

FY 1995

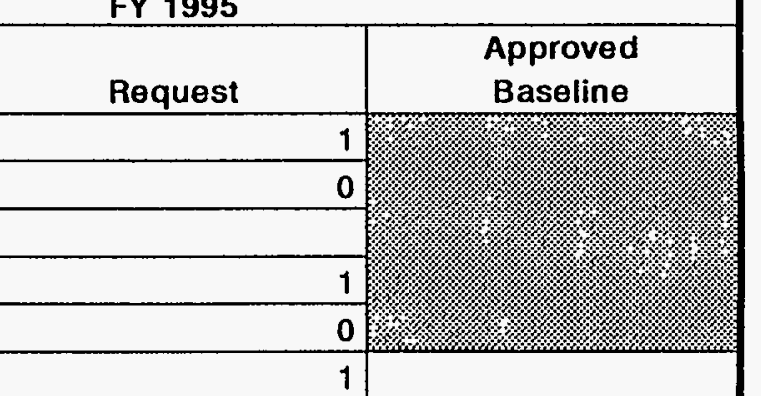




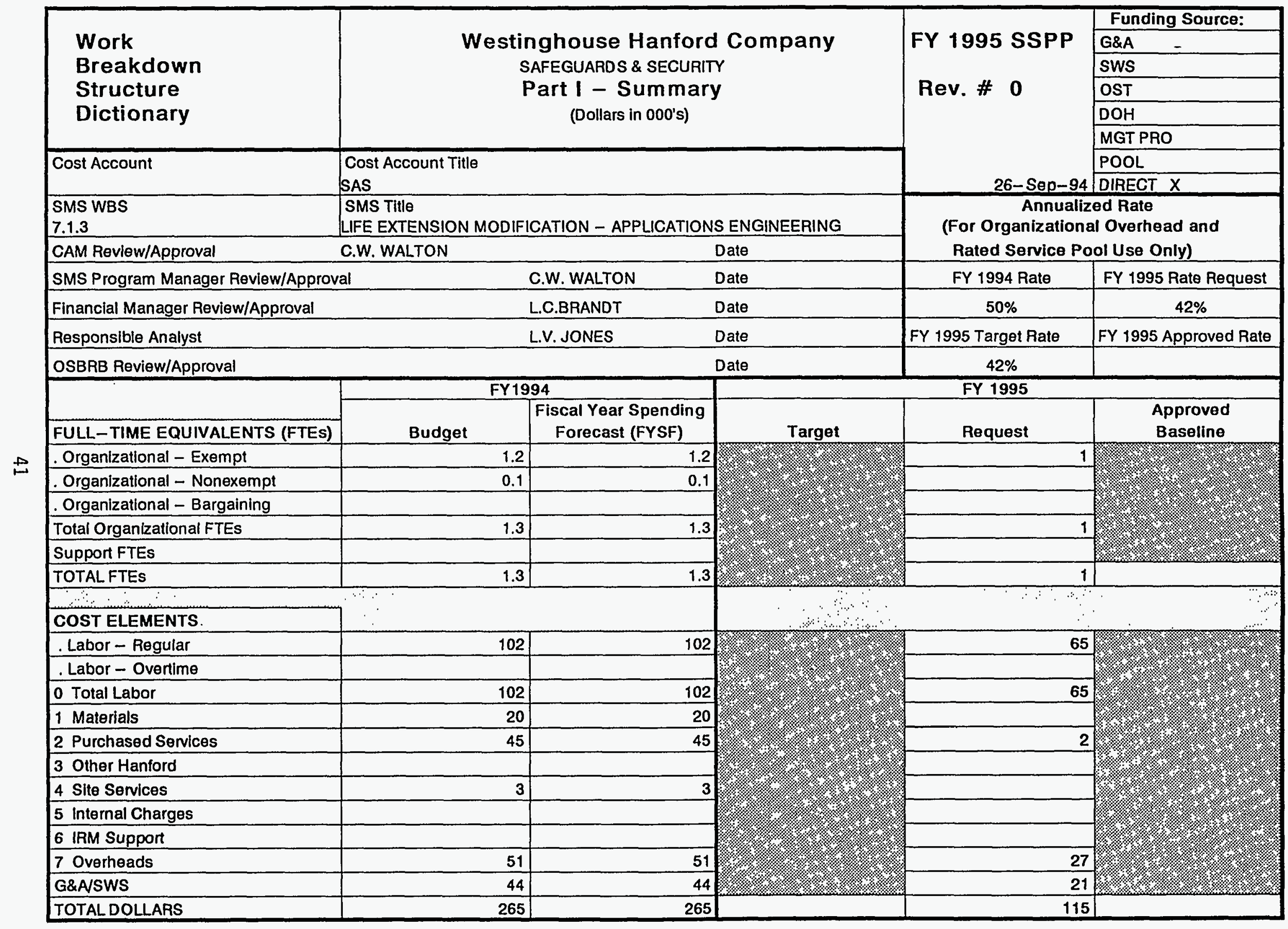




\section{Work Breakdown \\ Structure \\ Dictionary}

Westinghouse Hanford Company

Safeguards and Security

Part II - Element Definition

\section{FY 1995 SSSP}

Revision \#0

\begin{tabular}{|l|l|}
\hline WBS ELEMENT CODE: 7.1 .3 & TITLE: $\begin{array}{l}\text { Applications Engineering support to SAS physical } \\
\text { security system 7ife extension - PFP }\end{array}$ \\
\hline
\end{tabular}

ELEMENT TASK DESCRIPTION

\section{COST CONTENT -}

FY 95 - PFP direct funded program

FY 94 - STPO funded

IECHNICAL CONTENT - SAS Physical Security Protection System - Life Extension Modification

OBJECTIVES - Support the team established for replacement of the SAS Alarm Monitoring System. This support would include establishing performance requirements and performance testing.

Support the team established to assess and plan the replacement of the Safeguards accounting system at PFP. This support would include the preparation of minimum performance requirements of the software to perform this function.

\section{ASSUMPTIONS/CONSTRAINTS -}

\section{Assumptions}

PFP decides to pursue the option of SAS-AMS replacement with a PC based system.

A nuclear accounting system replacement will be required and a team will established to effect the timely implementation.

\section{MILESTONES -}

(support milestones established by the plant at a higher level)

\section{DELIVERABLES -}

Verify PFP AMS requirements through physical testing of the PC AMS test bed located at the FFTF.

(support other deliverables established by the plan) 


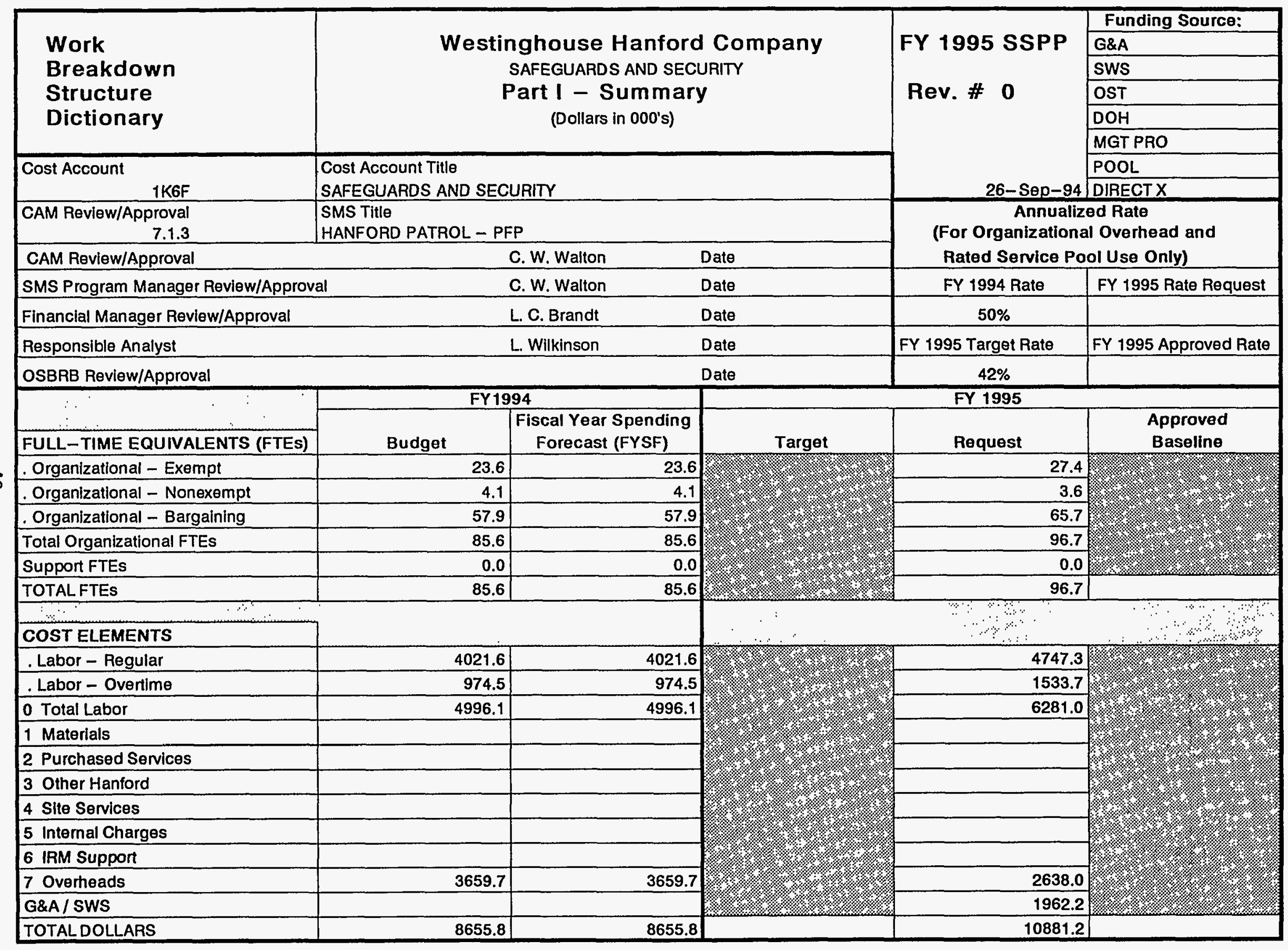


Work Breakdown

Structure

Dictionary
Westinghouse Hanford Company Safeguards and Security Part II - Element Definition
FY 1995 SSPP

Revision \#0

WBS ELEMENT CODE $\quad 7.1 .3$

TITLE: Hanford Patrol

ELEMENT TASK DESCRIPTION

COST CONTENT -

This cost account is funded by the 1K Facility Operations Program and covers Patrol support to PFP.

\section{TECHNICAL CONTENT -}

Provide a professional protective force that is highly trained and effective in techniques for physical protection, emergency response, and public service. Support for PFP includes a 24-hour operation for a central alarm monitoring station, access control for the material access area and protected area, and supervision by a shift lieutenant. The PFP is provided with 24-hour posts to support 4 protected area rovers, a roof-top observation post, and routine coverage by SRT members. Protective force members are supported by IDA sensors, cameras, X-Ray machines, and metal/SNM detectors. PFP is also allocated a portion of the PTA, Shift Commander, and POC support.

DOE Order 5632.7 - Protective Forces

DOE Order 5631.1A - Protection Program Operation

DOE Order 5632.1C - Protection and Control of Safeguards and Security Interests

\section{OBJECTIVES -}

Physically protect Special Nuclear Material, classified information, U.S. Government property, and personnel as a service to PFP.

\section{ASSUMPTIONS/CONSTRAINTS -}

The Patrol force will continue to be responsible to respond to and control any incident that threatens 1 ife or property on the Site until relieved by other authority.

\section{MILESTONES -}




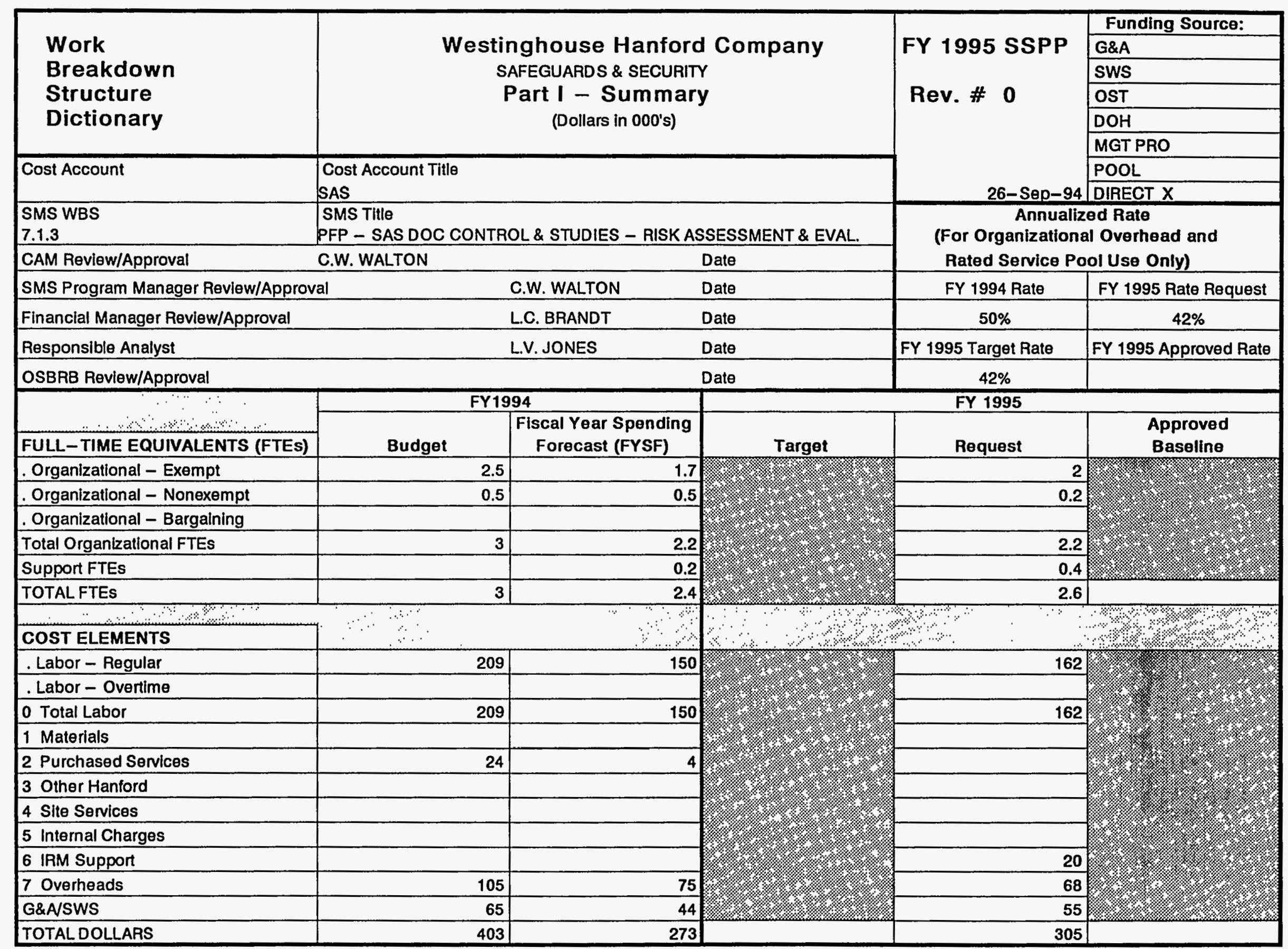




\section{Work Breakdown}

Structure

Dictionary

Westinghouse Hanford Company

Safeguards \& Security

Part II - Element Definition
FY 1995 SSSP

Revision \#0

\begin{tabular}{|c|c|}
\hline WBS ELEMENT CODE: 7.1 .3 & TITLE: PFP -SAS DOC CONTROL \& STUDIES \\
\hline \multicolumn{2}{|l|}{ ELEMENT TASK DESCRIPTION } \\
\hline \multicolumn{2}{|l|}{ COST CONTENT . } \\
\hline \multicolumn{2}{|l|}{ Direct funding from PFP. } \\
\hline \multicolumn{2}{|l|}{ TECHNICAL CONTENT - } \\
\hline \multicolumn{2}{|c|}{$\begin{array}{l}\text { Update and finalize the PFP Vulnerability Analysis Report (VAR) and Safeguards and Security Management Report (SSMR) for } \\
\text { inclusion into the Hanford Site SSSP. Complete the PFP upgrade evaluation. Conduct other studies/evaluations as } \\
\text { required. Conduct validation testing of upgrades. Regulatory drivers that impact the element are DOE } 5630.14 A \\
\text { "Safeguards and Security Program Planning," DOE 5630.13A "Master Safeguards and Security Agreements," and DOE N 5630.3A } \\
\text { "Protection of Departmental Facilities Against Radiological and Toxicological Sabotage." }\end{array}$} \\
\hline \multicolumn{2}{|l|}{ OBJECTIVES - } \\
\hline \multicolumn{2}{|c|}{$\begin{array}{l}\text { To complete the PFP VAReport for FY 1995. To complete the SSMR for FY } 1995 \text {. To complete special studies/evaluations to } \\
\text { support cost effective risk reduction (movement and storage for non-specific SNM). To conduct validation and } \\
\text { performance testing as required to validate protection effectiveniss and risk. }\end{array}$} \\
\hline \multicolumn{2}{|l|}{ ASSUMPTIONS/CONSTRAINTS - } \\
\hline \multicolumn{2}{|c|}{$\begin{array}{l}\text { FY } 1995 \text { VAR and SSMR as primary parts of the Hanford Site Safeguards and Security Plan will be updated based on } \\
\text { Category I and II SNM holdings and radiological/toxicological sabotage interests at the facility. }\end{array}$} \\
\hline \multicolumn{2}{|l|}{ MILESTONES - } \\
\hline \multicolumn{2}{|c|}{ PFP VAR and SSMR for FY 1995 are to be completed by September 1995.} \\
\hline \multicolumn{2}{|l|}{ DELIVERABLES - } \\
\hline $\begin{array}{l}\text { PFP VAR - September } 1995 \\
\text { PFP SSMR - September } 1995\end{array}$ & \\
\hline
\end{tabular}




\section{ELEMENT TASKDESCRIPTION}

WORK STATEMENT -

REQUESTS WITHIN TARGET:

Activity Detailed Description

Northem security operations support to PFP SAS Actlvity

Activity Detalled Descriptlon

Safeguards support to PFP SAS Activity

Activity Detalled Description

Safeguards support to PFP SNM Vault Activity

\section{Activity Detalled Description}

Application Engineering support to PFP SNM Vault Activity (IAEA)

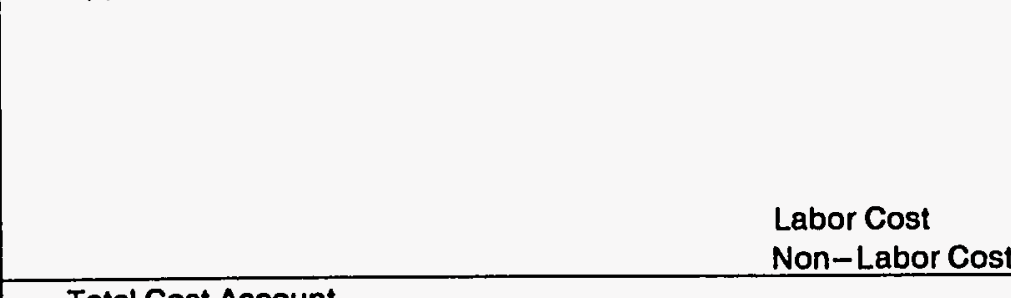

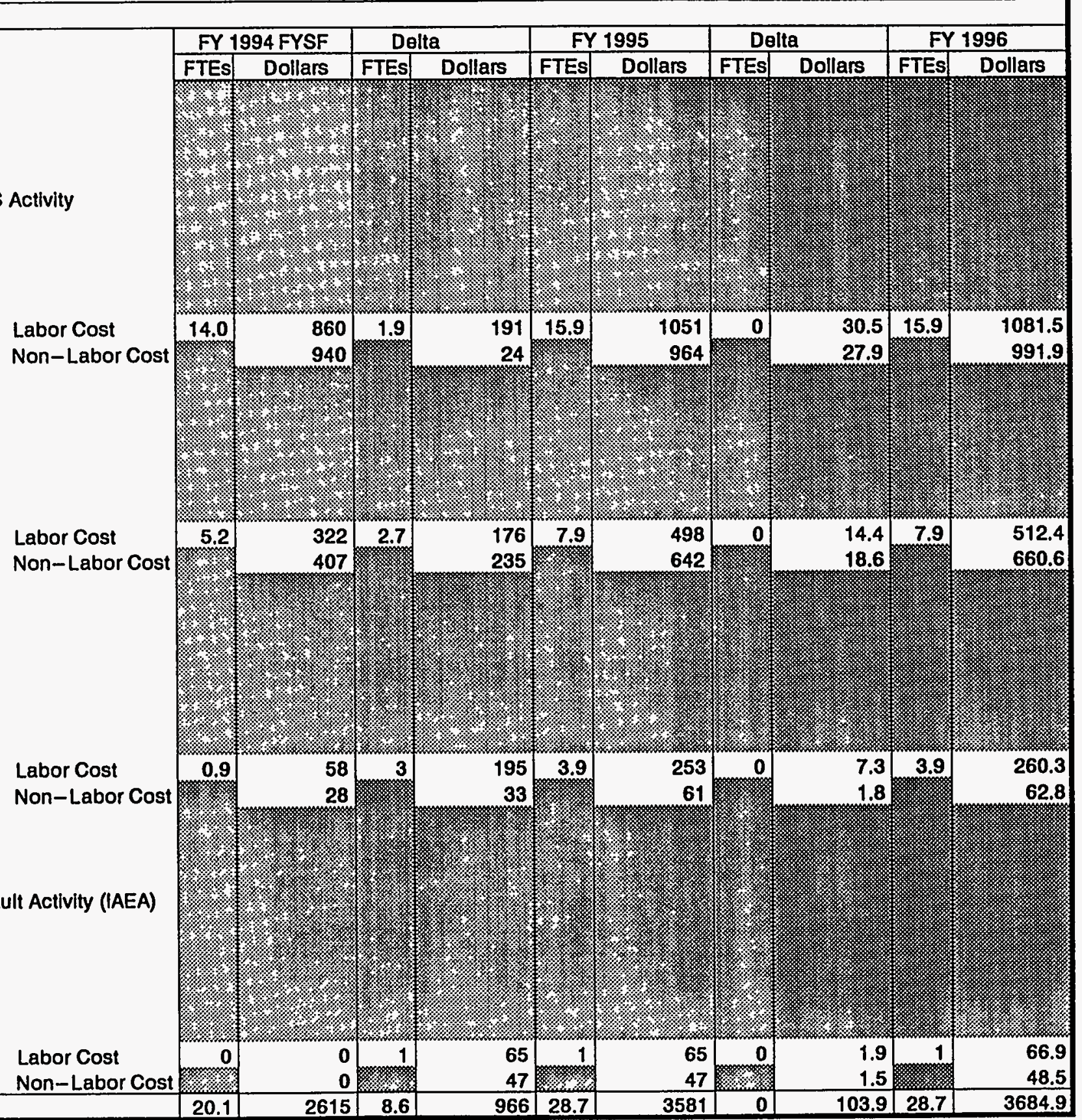

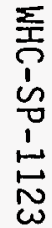




\section{WORK STATEMENT -}

REQUESTS WITHIN TARGET:

Activity Detalled Description

Applications Engineering support to PFP Life Extension Activity

Activity Detalled Description

Hanford Patrol support to PFP

Activity Detalled Description

Complete and update risk assessments for PFP

\section{Activity Detalled Description}

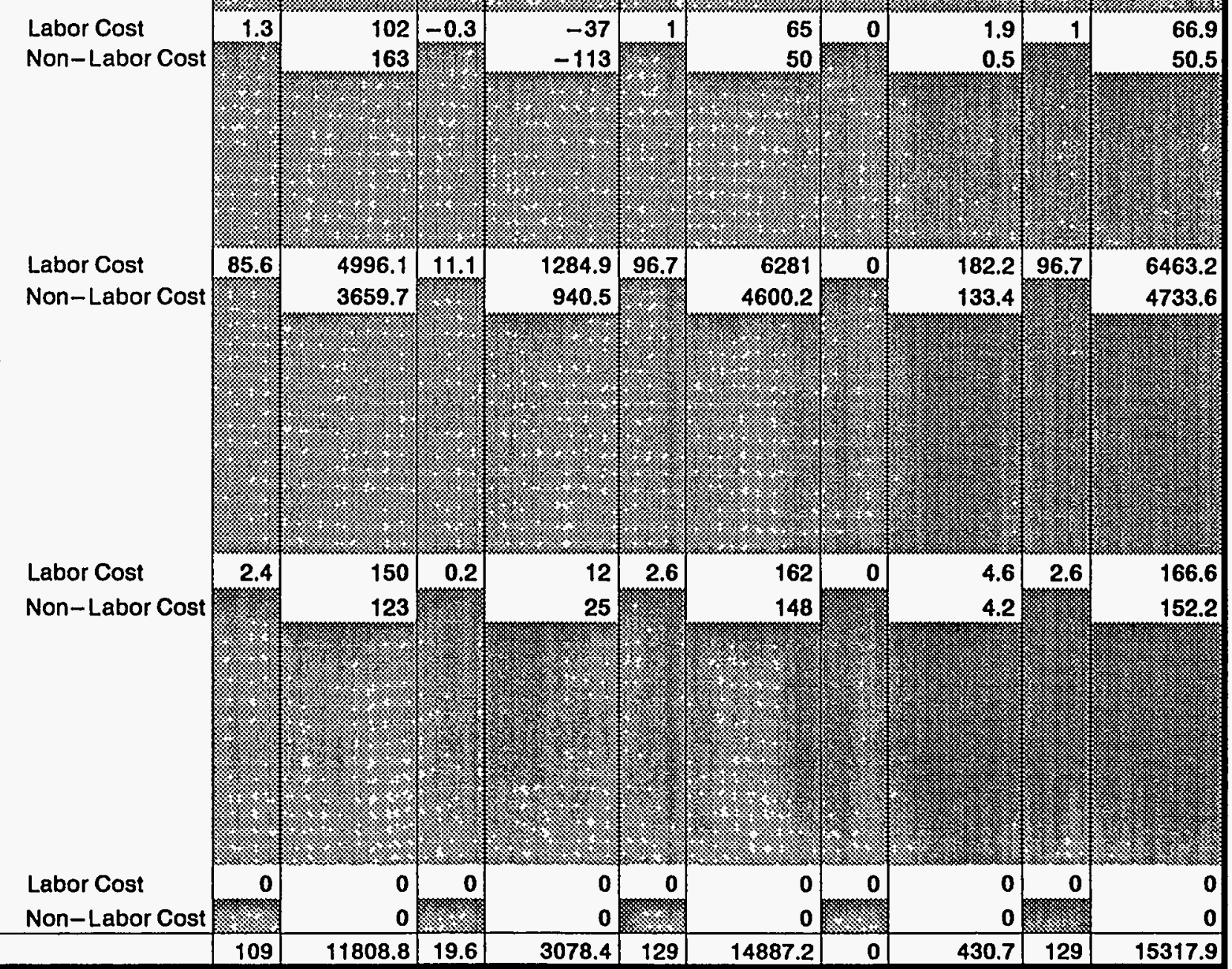

Delta

FY 1995

Delta

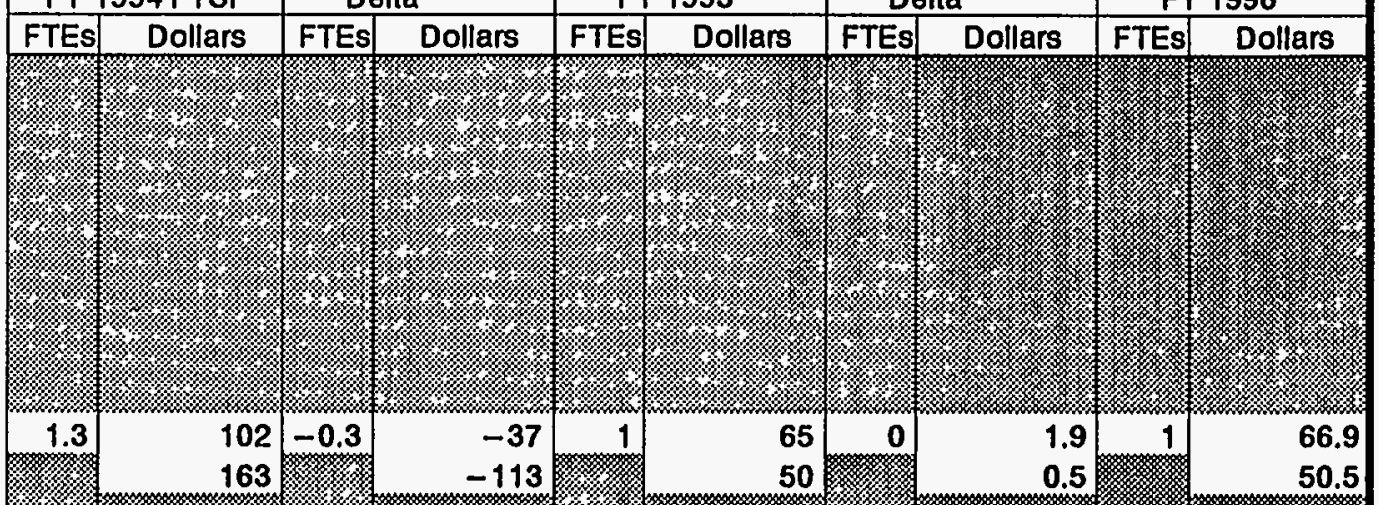




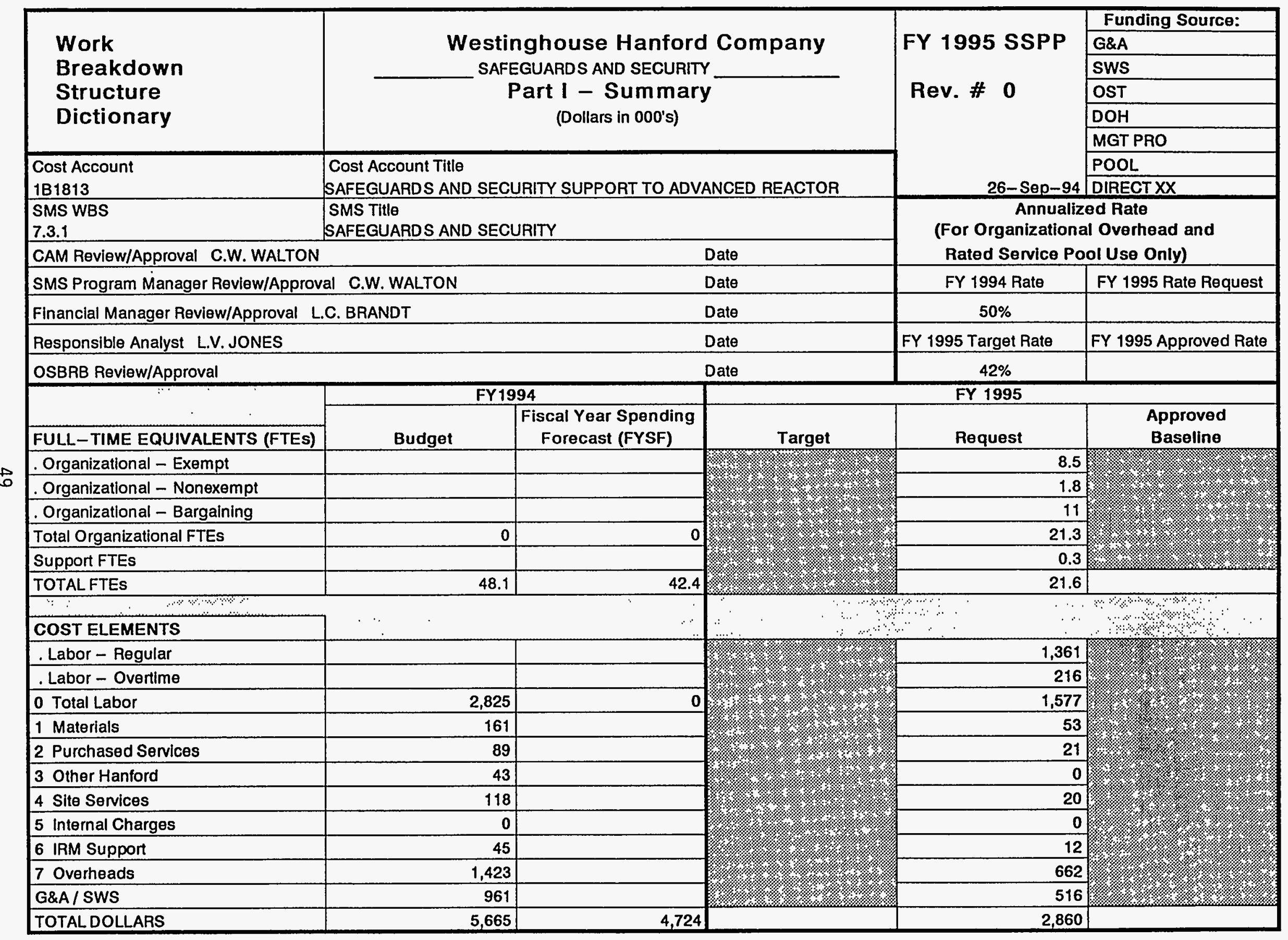




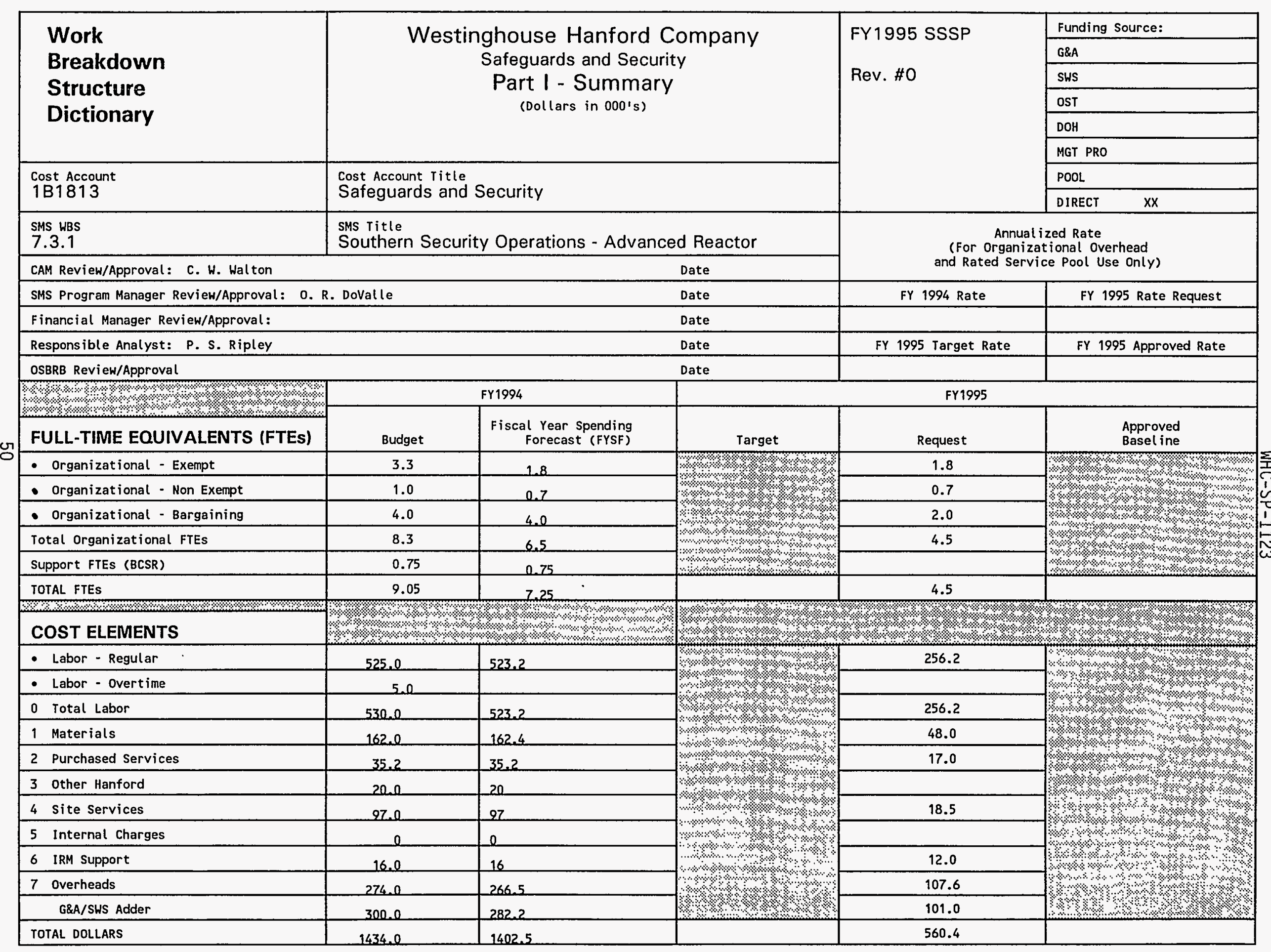




\begin{tabular}{|l|c|c|}
\hline \multicolumn{1}{|c|}{\begin{tabular}{|c}
\multicolumn{1}{|c|}{$1 \mathrm{~B} 1813$} \\
COST ACCOUNT
\end{tabular}} & Westinghouse Hanford Company \\
\hline $\begin{array}{l}\text { Work Breakdown } \\
\text { Structure } \\
\text { Dictionary }\end{array}$ & Safeguards and Security & FY 1995 SSSP \\
\hline
\end{tabular}

\begin{tabular}{|l|l|}
\hline WBS ELEMENT CODE: 7.3.1 & TITLE: Southern Security Operations - Advanced Reactor \\
\hline ELEMENT TASK DESCRIPTION \\
COST CONTENT - Direct - Advanced Reactor \\
TECHNICAL CONTENT - \\
Primary Mission \\
Maintain a standardized program for the FFTF (Advanced Reactor) site security functions consistent with the current DOE \\
Orders, RL Directives and company policies and procedures. Ensure safe, productive, compliant operations to assure \\
precise support in accordance with a changing site mission and vision, while attaining fully satisfactory audits. \\
Perform area 1iaison for the resolution of security discrepancies, concerns and emergencies. \\
- Provide a continued safe, more cost-effective Security Operations program in support of the FFTF. \\
Regulatory and relate organizational goals with site mission changes and effectively meet company and RL objectives. \\
All related activities have internal checks and balances to assure system readiness. Records are kept in compliance with \\
DOE-RL Directives, audit requirements and applicable WHC Policies and Procedures.
\end{tabular}

- Self Assessment.

- Award Fee Goals.

- Tracking and Charting of system performances .

- Programmatic Customer Satisfaction Surveys Completed.

- DOE Order 5000.3B, "Occurrence Reporting and Processing of Operations Information"

- DOE Order 5630.15, "DOE-SAS Training Certification Order"

- DOE Order 5631.1b, "Security Education Briefing and Awareness Program"

- DOE Order 5631.1A, "Security Education Program"

- DOE Order 6430.1A, "General Design Criteria"

- DOE-HQ/OSS, "Standards and Criteria"

- DOE-RL, "Performance Specification of Intrusion Detection Systems"

- WHC-CM-4-33, "WHC Security Manual"

- WHC-IP-0046," "Security Operations Instructional Procedure Manual"

- WHC-CM-6-1, "WHC Standard Engineering Practices" 


\begin{tabular}{|l|c|c|}
\hline \multicolumn{1}{|c|}{$\begin{array}{l}\text { 1B1813 } \\
\text { COST ACCOUNT }\end{array}$} & Westinghouse Hanford Company & FY 1995 SSSP \\
\hline $\begin{array}{l}\text { Work Breakdown } \\
\text { Structure } \\
\text { Dictionary }\end{array}$ & Safeguards and Security & Revision \#0 \\
\hline
\end{tabular}

\begin{tabular}{|l|l|}
\hline WBS ELEMENT CODE: 7.3.1 & TITLE: Southern Security Operations - Advanced Reactor \\
\hline
\end{tabular}

\section{ELEMENT TASK DESCRIPTION (cont'd)}

\section{OBJECTIVES -}

- Provide Security representation and education to maximize site security efficiency and minimize the generation of Incident Reports.

- Continue to provide specialized security engineering designs, planning and over-view support and approvals for area security systems, projects, facilities and security policy changes.

- Provide systems maintenance, informal status, upgrades QC/QA per DOE Order requirements for applicable security sensors. To include support for Audit issues.

- Coordinate WHC compliance with applicable DOE Orders, RLID's, policies and procedures.

- Assure compliance with all safety and environmental regulations as they apply to the physical security program.

- Safely maintain a fully compliant hazardous waste satellite retention center for system and organizational disposal.

\section{ASSUMPTIONS/CONSTRAINTS -}

- The FFTF Contain a Protected Area.

- Existing Limited Area Islands will be maintained.

- Continue to provide review and assure implementation of new orders, directives and RLID's.

- Continue to maintain a standardized Security Systems Testing program.

- Access control procedures will be revised to reflect changing mission and/or order requirements.

- All new or deleted work scope impacts not yet identified will be handled via change control.

- Property Protection Areas and Limited Areas will be maintained as required.

- Engineering and Crafts support to maintain and service automated entry systems.

- Maintain safeguards and security representation and complete Vulnerability Assessment (VA) for the FFTF.

- Sustain and maximize operational security systems performance including operation of a compliant, effective, preventive and remedial program.

\section{MILESTONES -}

The Program has not identified any milestones for this funding source. 


\begin{tabular}{|l|c|c|}
\hline \multicolumn{1}{|c|}{$\begin{array}{l}\text { 1B1813 } \\
\text { COST ACCOUNT }\end{array}$} & & FY 1995 SSSP \\
\hline $\begin{array}{l}\text { Work Breakdown } \\
\text { Structure } \\
\text { Dictionary }\end{array}$ & Westinghouse Hanford Company & Safeguards and Security \\
\hline
\end{tabular}

\begin{tabular}{|l|l|}
\hline WBS ELEMENT CODE: 7.3.1 & TITLE: Southern Security Operations - Advanced Reactor \\
\hline
\end{tabular}

ELEMENT TASK DESCRIPTION (cont'd)

\section{DELIVERABLES -}

- Provide timely response and completion of all Priority Work Requests.

- Develop, review and complete Preventive Maintenance (PM) routines per PM Procedures and frequencies.

- Provide specialized security technical guidance, engineering and maintenance to program departments in the southern area.

- Ensure systems and sensor performance are compliant and consistent with DOE Orders, WHC Policies and Procedures through Performance Review and configuration control.

- Provide Site facilities security evaluation reviews, reporting support and Asset protection checks.

- Support the development Hanford Security Interest Maps - Documents locations of security interests and 1imited areas.

- Award Fee Input - Provide input to RL in development of Contractor Award Fee.

- RL Survey Program support.

- WHC Site Selection Task Group - Support project reviews.

- WHC Controlled Manual Reviews.

- Performance Indicators - Deveiop program performance indicators.

- Program Organization - Develop plan to address physical security organization and workscope.

- Implement revised RLID 5632.1B, "Asset Protection Requirements."

- Provide support for Emergency Response Centers.

- Provide a sensor testing program that includes evaluation/validation of established security standards. 


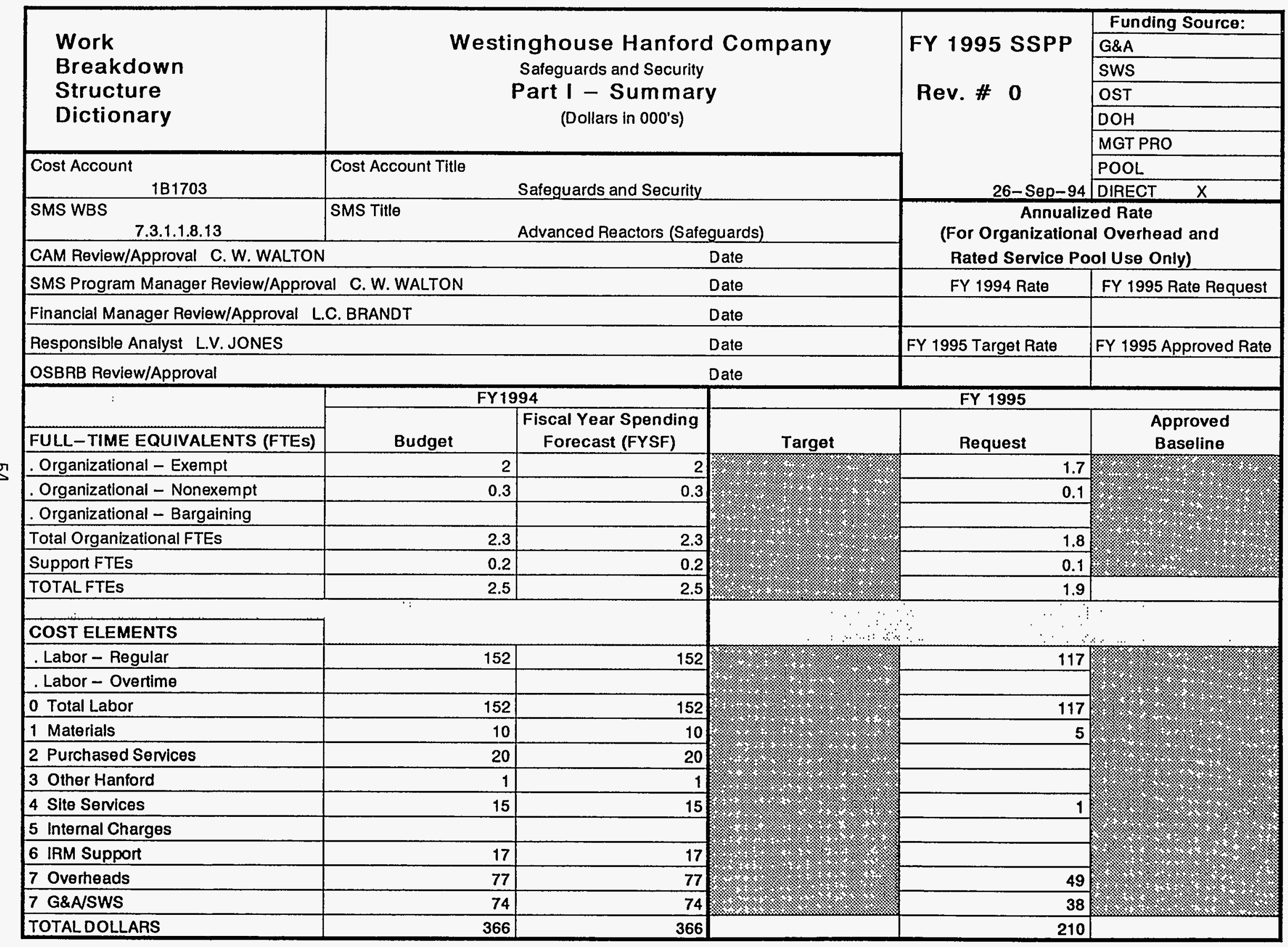




\begin{tabular}{|l|c|c|}
\hline \multicolumn{1}{|c|}{$1 \mathrm{1B1703}$} & & FY 1995 SSPP \\
\hline $\begin{array}{l}\text { CosT ACCOUNT } \\
\text { Structure } \\
\text { Dictionary }\end{array}$ & Westinghouse Hanford Company & Revision \# 0 \\
\hline
\end{tabular}

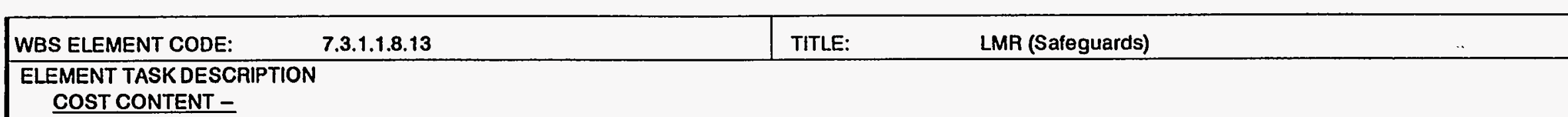

\section{COST CONTENT -}

This element is funded by the FFTF Plant.

\section{TECHNICAL CONTENT -}

This element is responsible for developing, maintaining, and implementing policies and procedures governing the use, control and accountability of nuclear materials in conformance with DOE orders. Regulatory drivers that impact the element are DOE 5633.3A, "Control and Accountability of Nuclear Materials", DOE 5633.4, "Nuclear Materials Transactions: Documentation and Reporting", DOE 5633.5, "Nuclear Materials Reporting and Data Submission Procedures", and RLID 5633.3A, "Control and Accountability of Nuclear Materials at Richland Operations Office".

\section{OBJECTIVES -}

The element will control and account for WHC nuclear materials in a manner that meets the requirements of federal and state regulations, DOE Orders, safety and environmental compliance requirements, and other WHC company policies. In addition, the element will proactively identify MC\&A issues, develop workable solutions, and follow through on implementation of solutions.

\section{ASSUMPTIONS/CONSTRAINTS -}

The Fast Flux Test Facility (FFTF) Category I material interests will remain a Protected Area (PA).

\section{MILESTONES -}

None

DELIVERABLES -

- Monthly and quarterly nuclear materlal reports for RL Safeguards and RL. Programs

- MC\&A training records including course completion rosters, custodian authorizations, OJT checklists, and exams

- NMMSS transaction and inventory data

- Physical inventory records including schedules, inventory plans, releases to resume activities, signed PRE- 416 reports, and RL-430 certiflcatlon forms

- RL Survey questionnalre

- Quarterly report from historical inventory difference database

- TID records on applications, removals, locations and inventory 


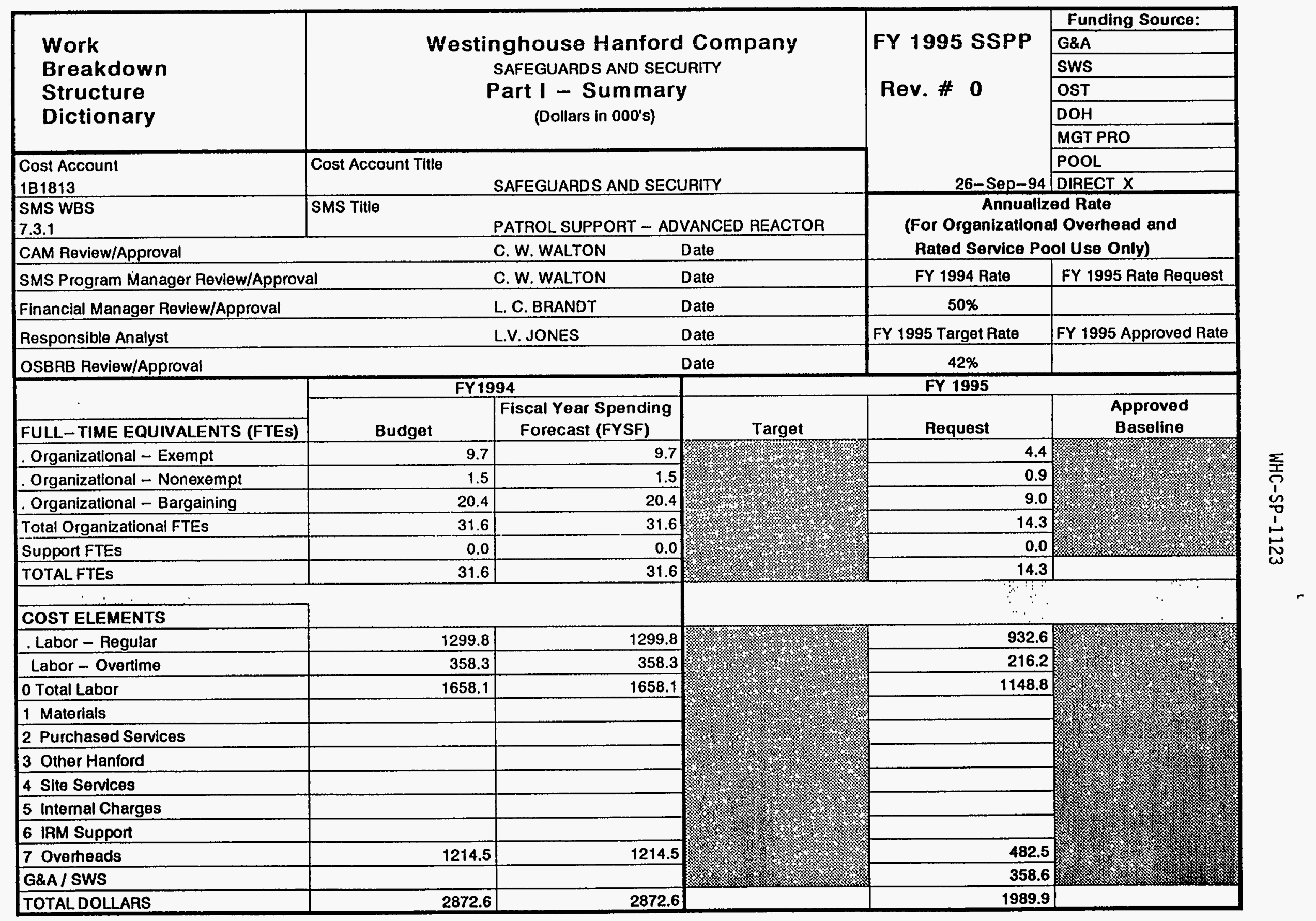




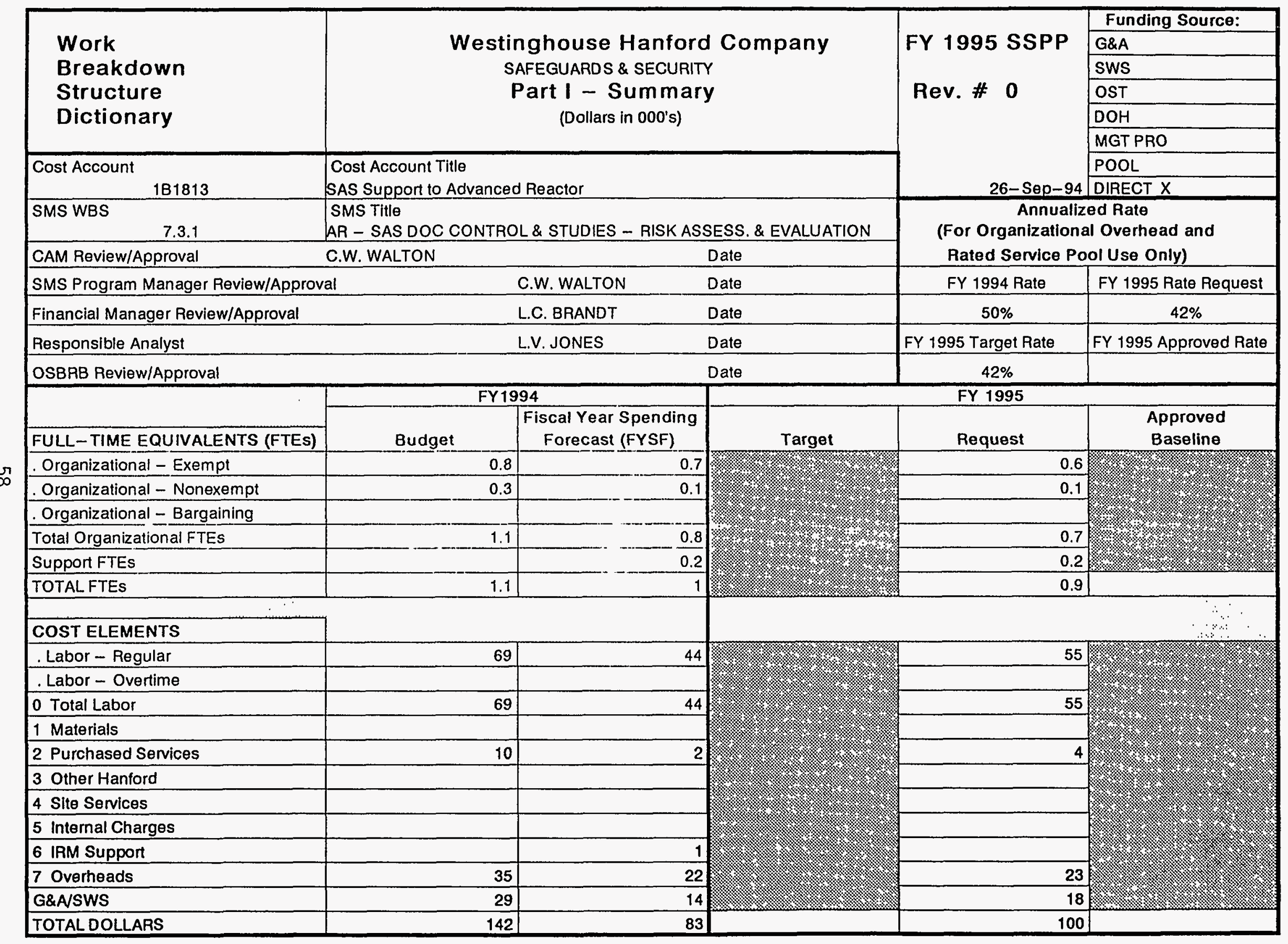


$n$

\begin{tabular}{|c|c|c|}
\hline COST ACCOUNT & & \\
\hline $\begin{array}{l}\text { Work Breakdown } \\
\text { Structure } \\
\text { Dictionary }\end{array}$ & $\begin{array}{c}\text { Westinghouse Hanford Company } \\
\text { Safeguards \& Security } \\
\text { Part II - Element Definition }\end{array}$ & $\begin{array}{c}\text { FY } 1995 \text { SSSP } \\
\text { Revision \#0 }\end{array}$ \\
\hline
\end{tabular}

\begin{tabular}{|l|l|}
\hline WBS ELEMENT CODE: 7.3 .1 & TITLE: FFTF - SAC DOC CONTROL \& STUDIES \\
\hline ELEMENT TASK DESCRIPTION \\
COST CONTENT - Direct funding from FFTF. \\
TECHNICAL CONTENT - \\
Conduct radiological sabotage validation and toxicological sabotage evaluation. Update the FFTF VAR and SSMR for \\
submittal into the FY 1995 Hanford Site Safeguards and Security Plan.
\end{tabular}

\section{OBJECTIVES -}

To complete radiological sabotage validation. To complete toxicological sabotage evaluation. To update and complete the FFTF VAR for FY 1995. To update and complete the FFTF SSMR for FY 1995.

\section{ASSUMPTIONS/CONSTRAINTS-}

VAR and SSMR as primary parts of the Hanford Site Safeguards and Security P1an will be updated based on Category I SNM and radiological/toxicological sabotage interests at the facility.

\section{MILESTONES -}

FFTF toxicological sabotage evaluation report, and the VAR and SSMR updates to be completed by September 1995.

\section{DELIVERABLES -}

Toxicological sabotage evaluation report - December 1995

VAR - September 1995

SSMR - September 1995 


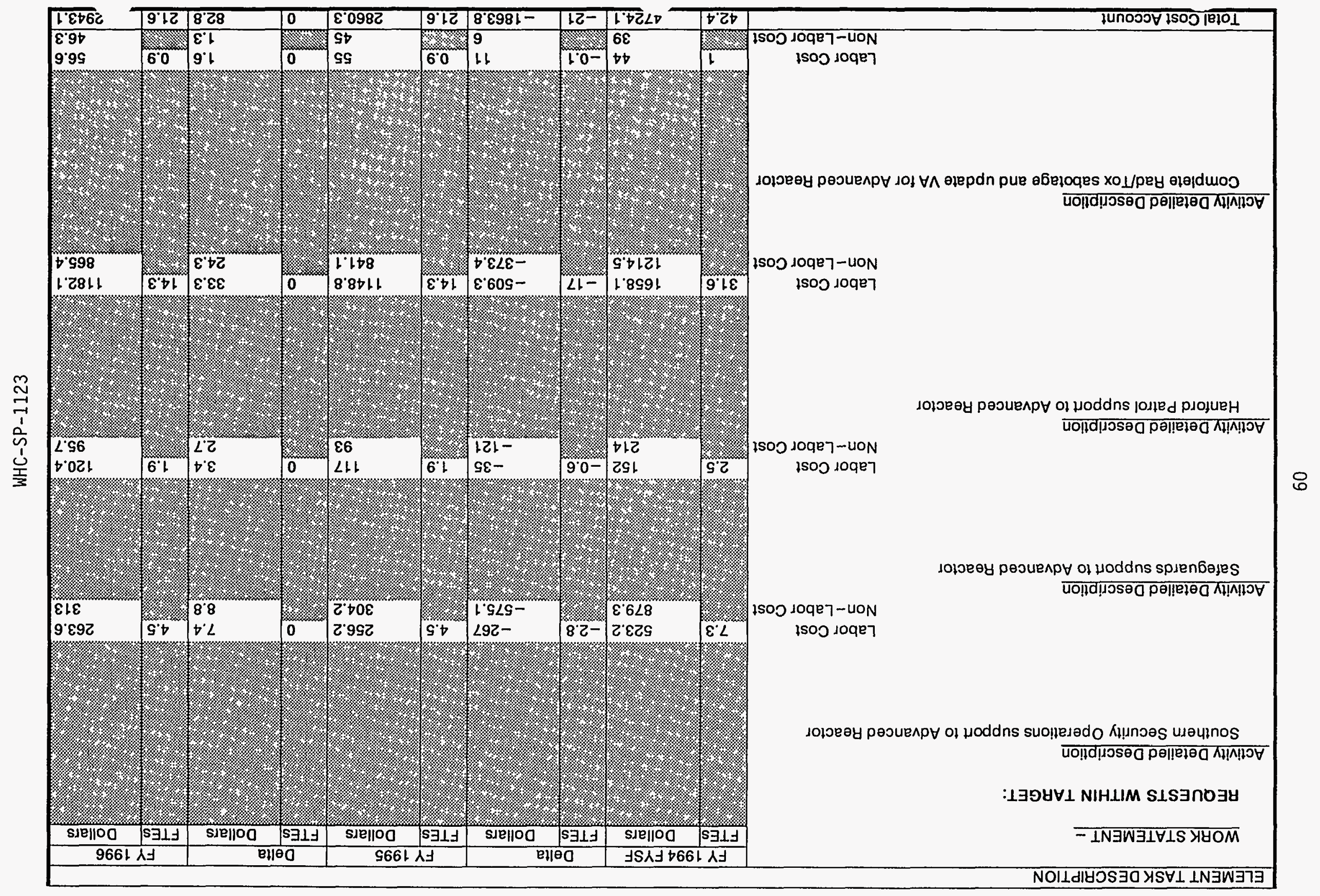




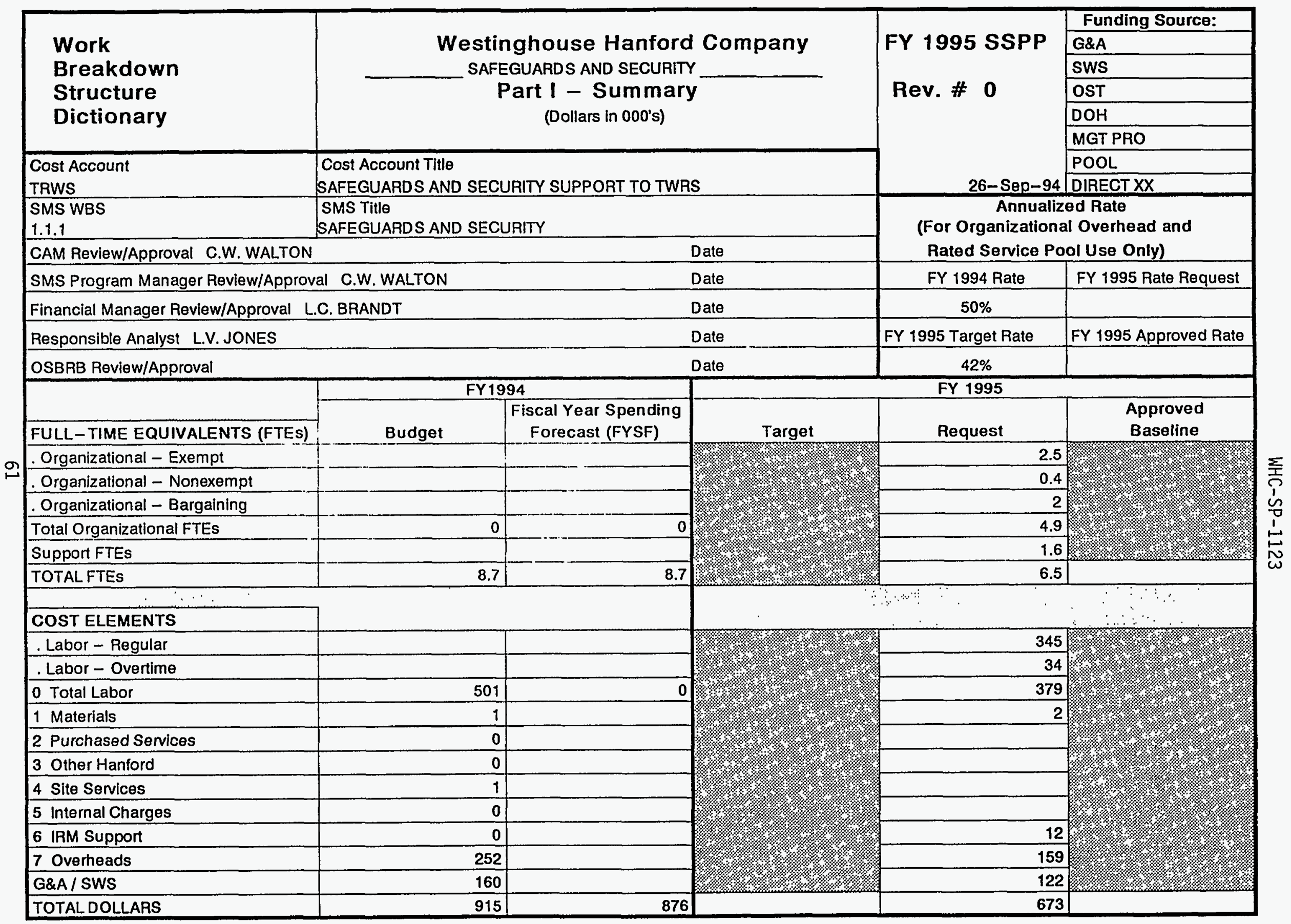




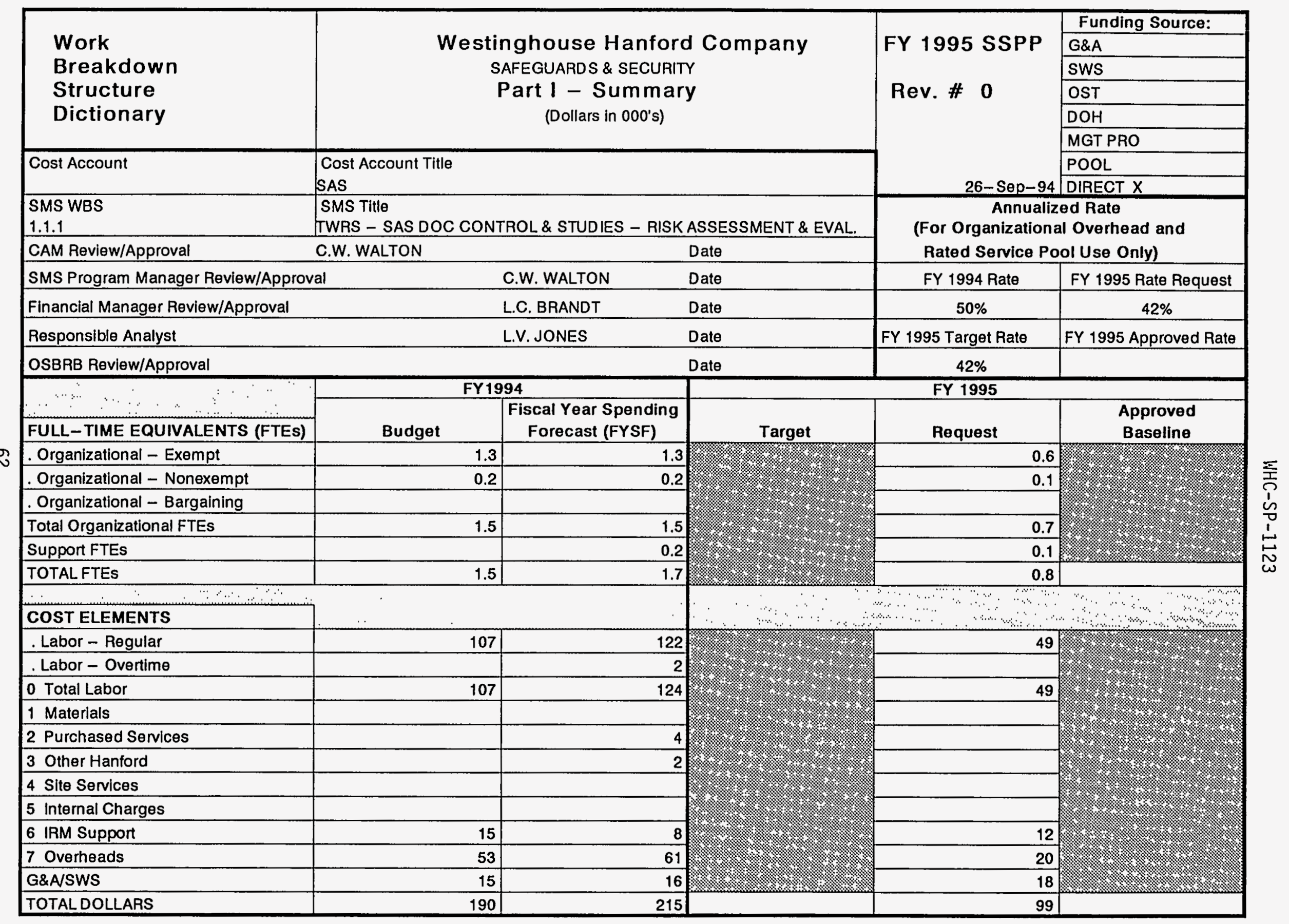




\begin{tabular}{|c|c|c|c|c|c|}
\hline \multirow{6}{*}{$\begin{array}{l}\text { Work } \\
\text { Breakdown } \\
\text { Structure } \\
\text { Dictionary }\end{array}$} & \multirow{6}{*}{\multicolumn{3}{|c|}{$\begin{array}{c}\text { Westinghouse Hanford Company } \\
\text { SAFEGUARDS \& SECURITY } \\
\text { Part I - Summary } \\
\text { (Dollars in } 000^{\prime} \text { 's) }\end{array}$}} & \multirow{8}{*}{$\begin{array}{l}\text { FY } 1995 \text { SSPP } \\
\text { Rev. \# } 0\end{array}$} & Funding Source: \\
\hline & & & & & G\&A \\
\hline & & & & & SWS \\
\hline & & & & & OST \\
\hline & & & & & $\mathrm{DOH}$ \\
\hline & & & & & MGT PRO \\
\hline Cost Account & \multirow{2}{*}{\multicolumn{3}{|c|}{$\begin{array}{l}\text { Cost Account Title } \\
\text { SAFEGUARDS AND SECURITY }\end{array}$}} & & $\mathrm{POOL}$ \\
\hline 1N1D47 (FY94) & & & & & 26-Sep-94 DIRECTXX \\
\hline $\begin{array}{l}\text { SMS WBS } \\
1.1 .1\end{array}$ & \multicolumn{3}{|c|}{$\begin{array}{l}\text { SMS Title } \\
\text { TANK FARM SECURITY OPERATIONS SUPPORT }\end{array}$} & \multirow{2}{*}{\multicolumn{2}{|c|}{$\begin{array}{c}\text { Annualized Rate } \\
\text { (For Organizational Overhead and } \\
\text { Rated Service Pool Use Only) }\end{array}$}} \\
\hline CAM Review/Approval & C.W. WALTON & \multicolumn{2}{|r|}{ Date } & & \\
\hline \multicolumn{2}{|l|}{ SMS Program Manager Review/Approval } & C.W. WALTON & Date & FY 1994 Rate & FY 1995 Rate Request \\
\hline \multicolumn{2}{|l|}{ Financial Manager Review/Approval } & L.C. BRANDT & Date & $50 \%$ & $42 \%$ \\
\hline \multicolumn{2}{|l|}{ Responsible Analyst } & L.V. JONES & Date & FY 1995 Target Rate & FY 1995 Approved Rate \\
\hline \multicolumn{3}{|l|}{ OSBRB Review/Approval } & Date & $42 \%$ & \\
\hline & \multicolumn{2}{|c|}{ FY1994 } & \multicolumn{3}{|c|}{ FY 1995} \\
\hline$\therefore \quad \therefore \quad: \quad \vdots$ & BUDGET & $\begin{array}{c}\text { Fiscal Year Spending } \\
\text { Forecast (FYSF) }\end{array}$ & Target & Request & $\begin{array}{c}\text { Approved } \\
\text { Baseline }\end{array}$ \\
\hline $\begin{array}{l}\text { FULL-TIME EQUIVALENTS (FTES) } \\
\text {. Organizational - Exempt }\end{array}$ & 1.3 & & 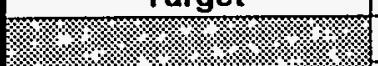 & 0.9 & (4) \\
\hline Organizational - Nonexempt & 0.4 & & & 0.3 & \\
\hline Organizational - Bargaining & 0 & & & 0 & \\
\hline Total Organizational FTEs & 1.7 & & : & 1.2 & \\
\hline Support FTES & 0 & & প।. & 0 & \% \\
\hline TOTAL FTES & 1.7 & & 1... & 1.2 & \\
\hline W & & 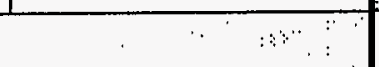 & $\because \quad \cdots$ & : : & अम \\
\hline COST ELEMENTS & $\therefore$ & & $\because \quad 3:$ & & . \\
\hline . Labor - Regular & 93 & 91 & & 68 & \\
\hline . Labor - Overtime & & & 1. & & \\
\hline 0 Total Labor & 93 & 91 & (1. & 68 & \% \\
\hline 1 Materials & 2 & 1 & 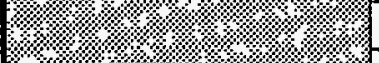 & 2 & 1: \\
\hline 2 Purchased Services & & & (19: & & (ষ. \\
\hline 3 Other Hanford & & & (1) & & \\
\hline 4 Site Services & & & 19 & & \\
\hline 5 Internal Charges & & & 4 & & \\
\hline 6 IRM Support & & & & & \\
\hline 7 Overheads & 46 & 45 & & 29 & \\
\hline G\&A/SWS & 35 & 35 & $1.2+2$ & 22 & $1 / 2 . \% .2 \%$ \\
\hline TOTAL DOLLARS & 176 & 173 & & 121 & \\
\hline
\end{tabular}




\begin{tabular}{|l|c|c|}
\hline \multicolumn{1}{|c|}{ COST ACCOUNT } & \multicolumn{2}{|c|}{ FY 1995 SSSP } \\
\hline $\begin{array}{l}\text { Work Breakdown } \\
\text { Structure } \\
\text { Dictionary }\end{array}$ & $\begin{array}{c}\text { Westinghouse Hanford Company } \\
\text { Safeguards and Security }\end{array}$ & Revision \#0 \\
\hline
\end{tabular}

\begin{tabular}{|c|c|}
\hline WBS ELEMENT CODE: 1.1 .1 & TITLE: NORTHERN SECURITY OPERATIONS SUPPORT TO TANK FARMS \\
\hline \multicolumn{2}{|l|}{ ELEMENT TASK DESCRIPTION } \\
\hline \multicolumn{2}{|c|}{$\begin{array}{l}\text { COST CONTENT - Develop and administer security support for all Tank Farms' facilities and provide coordination on al } \\
\text { physical security issues, key control, and security education. }\end{array}$} \\
\hline \multicolumn{2}{|c|}{$\begin{array}{l}\text { TECHNICAL CONTENT - According to applicable DOE Orders and Company Directives, provide specialized physical securits } \\
\text { protection guidance, security educational training, engineering, and key accountibility control. }\end{array}$} \\
\hline \multicolumn{2}{|c|}{$\begin{array}{l}\text { OBJECTIVES - Provide appropriate staffing to support the various Tank Farms' site security requirements. Adjust } \\
\text { organizational goals as needed to meet site mission changes. Provide specialized security representation and } \\
\text { engineering reviews for project designs and site planning as well as direct or approve facility security policy needs } \\
\text { and changes. }\end{array}$} \\
\hline \multicolumn{2}{|c|}{$\begin{array}{l}\text { ASSUMPTIONS/CONSTRAINTS - The RLID facility security requirements will continue to require consistant support. } \\
\text { Constant efforts will be directed towards ensuring that radiological sabotage risks are effectively mitigated. }\end{array}$} \\
\hline \multicolumn{2}{|l|}{ MILESTONES - None } \\
\hline $\begin{array}{l}\text { DELIVERABLES - Provide } \\
\text { Areas, including security }\end{array}$ & program support for all Tank Farm facilities within the 200 \\
\hline
\end{tabular}




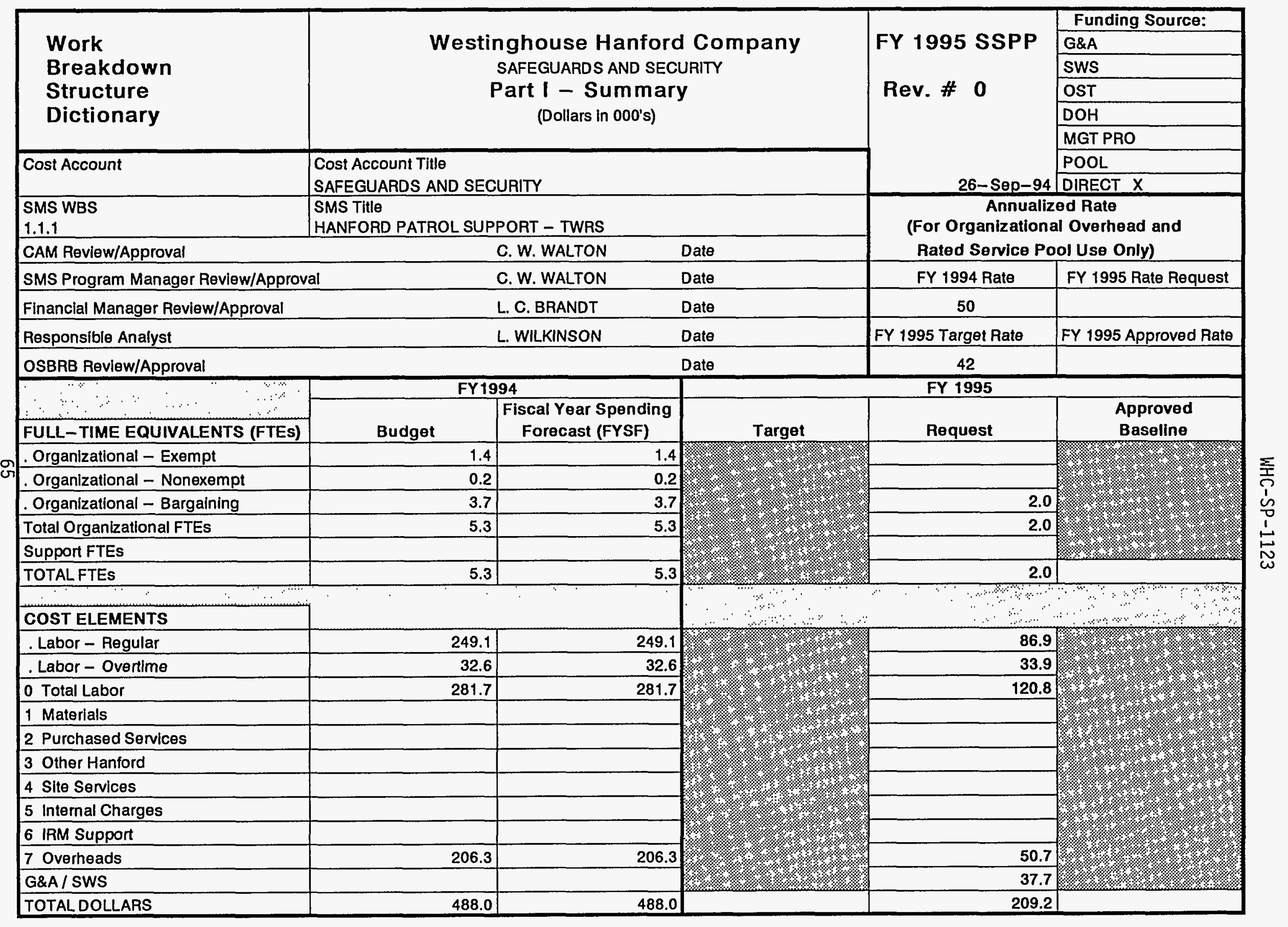




\begin{tabular}{|l|}
\hline \multicolumn{1}{|c}{ 1NID47 } \\
COST ACCOUNT \\
\hline $\begin{array}{l}\text { Work Breakdown } \\
\text { Structure } \\
\text { Dictionary }\end{array}$ \\
\hline
\end{tabular}

\section{Westinghouse Hanford Company}

FY 1995 SSPP

Dictionary

Safeguards and Security

Part II - Element Definition

Revision \#0

\begin{tabular}{|l|l|l|l|l}
\hline WBS ELEMENT CODE 1.1 .1 & TITLE: Hanford Patrol \\
\hline
\end{tabular}

ELEMENT TASK DESCRIPTION

COST CONTENT -

This cost account is funded by the IN Waste Tank Safety and Operations program and includes the Hanford Patrol support to Tank Farms.

\section{TECHNICAL CONTENT -}

Provide a professional protective force that is highly trained and effective in techniques for physical protection, emergency response, and public service. Tank Farms is provided 24-hour surveillance and periodic facility checks based on the Tank Farm VA. These checks are conducted by a SRT rover.

DOE Order 5632.7 - Protective Forces

DOE Order 5631.1A - Protection Program Operation

DOE Order 5632.1C - Protection and Control of Safeguards and Security Interests

\section{OBJECTIVES -}

Physically protect Special Nuclear Material, classified information, U.S. Government property, and personnel as a service to Tank Farms.

\section{ASSUMPTIONS/CONSTRAINTS -}

The Patrol force will continue to be responsible to respond to and control any incident that threatens 1 ife or property on the Site until relieved by other authority.

\section{MILESTONES -}

DELIVERABLES - 


\begin{tabular}{|c|c|c|c|c|c|}
\hline \multirow{6}{*}{$\begin{array}{l}\text { Work } \\
\text { Breakdown } \\
\text { Structure } \\
\text { Dictionary }\end{array}$} & \multirow{6}{*}{\multicolumn{3}{|c|}{$\begin{array}{c}\text { Westinghouse Hanford Company } \\
\text { SAFEGUARDS \& SECURITY } \\
\text { Part I - Summary } \\
\text { (Dollars in 000's) }\end{array}$}} & \multirow{8}{*}{$\begin{array}{l}\text { FY } 1995 \text { SSPP } \\
\text { Rev. \# } 0\end{array}$} & Funding Source: \\
\hline & & & & & G\&A \\
\hline & & & & & sws \\
\hline & & & & & OST \\
\hline & & & & & $\overline{\mathrm{DOH}}$ \\
\hline & & & & & MGT PRO \\
\hline \multirow{2}{*}{ Cost Account } & \multirow{2}{*}{\multicolumn{3}{|c|}{$\begin{array}{l}\text { Cost Account Title } \\
\text { SAS }\end{array}$}} & & POOL \\
\hline & & & & & DIRECT $X$ \\
\hline $\begin{array}{l}\text { SMS WBS } \\
1.1 .1\end{array}$ & \multicolumn{3}{|c|}{$\begin{array}{l}\text { SMS Title } \\
\text { NON SAS TANK FARM SUPPORT - APPLICATIONS ENGINEERING }\end{array}$} & \multirow{2}{*}{\multicolumn{2}{|c|}{$\begin{array}{c}\text { Annualized Rate } \\
\text { (For Organizational Overhead and } \\
\text { Rated Service Pool Use Only) } \\
\end{array}$}} \\
\hline CAM Review/Approval & \multicolumn{2}{|l|}{ C.W. WALTON } & DS ENGINEERING & & \\
\hline \multicolumn{2}{|c|}{ SMS Program Manager Review/Approval } & C.W. WALTON & Date & FY 1994 Rate & FY 1995 Rate Request \\
\hline \multicolumn{2}{|l|}{ Financial Manager Review/Approval } & L.C.BRANDT & Date & $50 \%$ & $42 \%$ \\
\hline \multicolumn{2}{|l|}{ Responsible Analyst } & L.V. JONES & Date & FY 1995 Target Rate & FY 1995 Approved Rate \\
\hline \multicolumn{2}{|l|}{ OSBAB Review/Approval } & & Date & $42 \%$ & \\
\hline \multirow{2}{*}{ FULL-TIME EQUIVALENTS (FTES) } & \multicolumn{2}{|c|}{ FY1994 } & \multicolumn{3}{|c|}{ FY 1995} \\
\hline & Budget & $\begin{array}{c}\text { Fiscal Year Spending } \\
\text { Forecast (FYSF) }\end{array}$ & Target & Request & $\begin{array}{l}\text { Approved } \\
\text { Baseline }\end{array}$ \\
\hline Organizational - Exempt & & & 4 & 18 & \\
\hline Organizational - Nonexempt & & & 1 & & \\
\hline Organizational - Bargaining & & & & & \\
\hline Total Organizational FTEs & 0 & 0 & 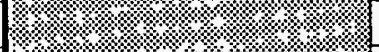 & 1. & \\
\hline Support FTEs & & & অ: & 1.5 & 8 \\
\hline TOTALFTES & 0 & 0 & 1 & 2.5 & \\
\hline COST ELEMENTS & & & :.. & 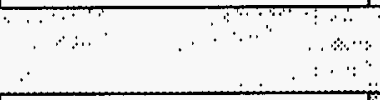 & क्ष \\
\hline . Labor - Regular & & & ) & 141 & \\
\hline . Labor - Overtime & & & (2) & & 4 \\
\hline 0 Total Labor & 0 & 0 & (1). & 141 & (1918. \\
\hline 1 Materials & & & (4) & & \\
\hline 2 Purchased Services & & & 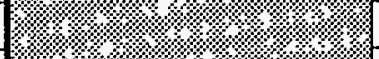 & & (1) \\
\hline 3 Other Hanford & & & (2) & & H) \\
\hline 4 Site Services & & & 1/: & & : \\
\hline 5 Internal Charges & & & & & (1: \\
\hline 6 IRM Support & & & & & \\
\hline 7 Overheads & & & & 59 & \% \\
\hline G\&ASWS & & & $4 \%$ & 44 & 18 \\
\hline TOTALDOLLARS & 0 & 0 & & 245 & \\
\hline
\end{tabular}




\begin{tabular}{|l|c|c|}
\hline \multicolumn{1}{|c|}{ COST ACcounT } & \multicolumn{2}{|c|}{ FY 1995 SSSP } \\
\hline $\begin{array}{l}\text { Work Breakdown } \\
\text { Structure } \\
\text { Dictionary }\end{array}$ & $\begin{array}{c}\text { Westinghouse Hanford Company } \\
\text { Security Operations Administration } \\
\text { Part II - Element Definition }\end{array}$ & Revision \#0 \\
\hline
\end{tabular}

\begin{tabular}{|l|l|}
\hline WBS ELEMENT CODE: 1.1 .1 & TITLE: NON SAS Tank Farm Support \\
\hline ELEMENT TASK DESCRIPTION
\end{tabular}

ELEMENT TASK DESCRIPTION

COST CONTENT -

TWRS direct funded - nonSAS work

TECHNICAL CONTENT -

Entry control enhancement - Smart Card system

@

OBJECTIVES -

Support the project team with system design and programming

ASSUMPTIONS/CONSTRAINTS :-

Full funding for the project will be received at the beginning of the fiscal year.

MILESTONES -

TBD - System design and programming

TBD - System operational

DELIVERABLES - 
WHC-SP-1123

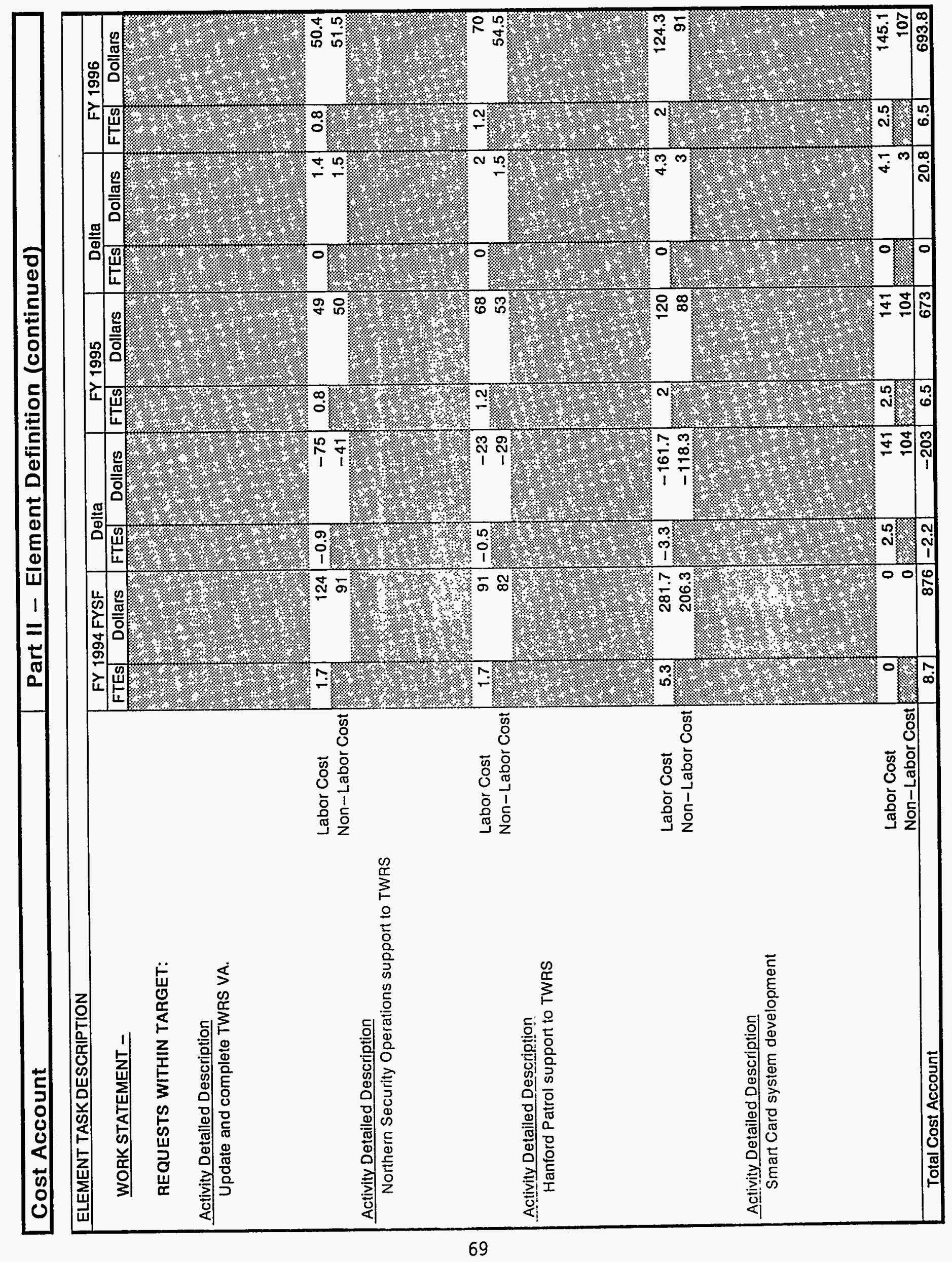




\begin{tabular}{|c|c|c|c|c|c|}
\hline \multirow{6}{*}{$\begin{array}{l}\text { Work } \\
\text { Breakdown } \\
\text { Structure } \\
\text { Dictionary }\end{array}$} & \multirow{6}{*}{\multicolumn{3}{|c|}{$\begin{array}{c}\text { Westinghouse Hanford Company } \\
\text { SAFEGUARDS AND SECURITY } \\
\text { Part I - Summary } \\
\text { (Dollars in 000's) }\end{array}$}} & \multirow{8}{*}{$\begin{array}{l}\text { FY } 1995 \text { SSPP } \\
\text { Rev. \# } 0\end{array}$} & Funding Source: \\
\hline & & & & & G\&A \\
\hline & & & & & SWS \\
\hline & & & & & OST \\
\hline & & & & & $\mathrm{DOH}$ \\
\hline & & & & & MGT PRO \\
\hline \multirow[t]{2}{*}{ Cost Account } & \multirow{2}{*}{\multicolumn{3}{|c|}{$\begin{array}{l}\text { Cost Account Titlo } \\
\text { SAFEGUARDS AND SECURITY SUPPORT TO SNF }\end{array}$}} & & POOL \\
\hline & & & & & DIRECT $X X$ \\
\hline \begin{tabular}{|l|} 
SMS WBS \\
1.4 .1 \\
\end{tabular} & \multicolumn{3}{|c|}{$\begin{array}{l}\text { SMS Titlo } \\
\text { SAFEGUARDS AND SECURITY }\end{array}$} & \multirow{2}{*}{\multicolumn{2}{|c|}{$\begin{array}{c}\text { Annualized Rate } \\
\text { (For Organizational Overhead and } \\
\text { Rated Service Pool Use Only) }\end{array}$}} \\
\hline \multicolumn{2}{|l|}{ CAM Review/Approval C.W. WALTON } & \multicolumn{2}{|r|}{ Date } & & \\
\hline \multicolumn{2}{|c|}{ SMS Program Manager Review/Approval $\quad$ C.W. WALTON } & \multicolumn{2}{|r|}{ Date } & FY 1994 Rate & FY 1995 Rate Request \\
\hline \multicolumn{2}{|c|}{ Financial Manager Review/Approval $\quad$ L.C. BRANDT } & \multicolumn{2}{|r|}{ Date } & $50 \%$ & \\
\hline \multicolumn{2}{|l|}{ Responsible Analyst L.V. JONES } & \multicolumn{2}{|r|}{ Date } & FY 1995 Target Rate & FY 1995 Approved Rate \\
\hline \multicolumn{2}{|l|}{ OSBRB Review/Approval } & \multicolumn{2}{|r|}{ Date } & $42 \%$ & \\
\hline \multirow[b]{2}{*}{$\begin{array}{ll}0 \\
\end{array}$} & \multicolumn{2}{|c|}{ FY1994 } & \multicolumn{3}{|c|}{ FY 1995} \\
\hline & Budget & $\begin{array}{l}\text { Fiscal Year Spending } \\
\text { Forecast (FYSF) }\end{array}$ & Target & Request & $\begin{array}{c}\text { Approved } \\
\text { Baseline }\end{array}$ \\
\hline \multicolumn{3}{|l|}{ Organizational - Exempt } & & 9.9 & \multirow{6}{*}{ 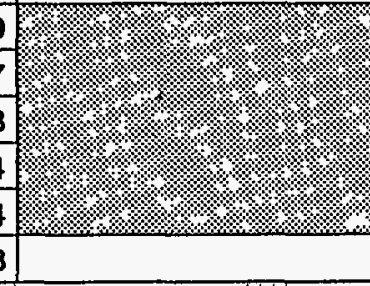 } \\
\hline Organizational - Nonexempt & & & & 1.7 & \\
\hline . Organizational - Bargaining & & & & 16.8 & \\
\hline Total Organizational FTEs & 0 & 의 & & 28.4 & \\
\hline Support FTES & & $\cdot$ & : & 0.4 & \\
\hline TOTAL FTES & 13.3 & 13 & (1.. & 28.8 & \\
\hline m. & $\therefore$ & & + & e. & \\
\hline COST ELEMENTS & & & 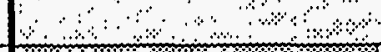 & 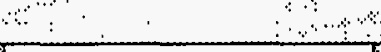 & s. \\
\hline . Labor - Regular & & & $4:$ & 1,497 & \%) \\
\hline . Labor - Overtime & & & 9.1 .1$. & 355 & \\
\hline 0 Total Labor & 821 & of & (4) & 1,851 & \\
\hline 1 Materials & 16 & & 1: & 10 & \\
\hline 2 Purchased Services & 0 & & (1) & 2 & \\
\hline 3 Other Hanford & 0 & & 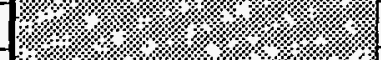 & & \\
\hline 4 Site Services & 3 & & (1) & 2 & \\
\hline 5 Internal Charges & 0 & & 4\%? & & \\
\hline 6 IRM Support & 0 & & & 0 & \\
\hline 7 Overheads & 410 & & 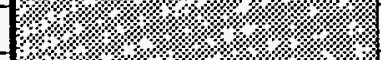 & 778 & \\
\hline G\&A / SWS & 242 & & & 581 & 1\%. \\
\hline TOTALDOLLARS & 1,491 & 1,415 & & 3,224 & \\
\hline
\end{tabular}




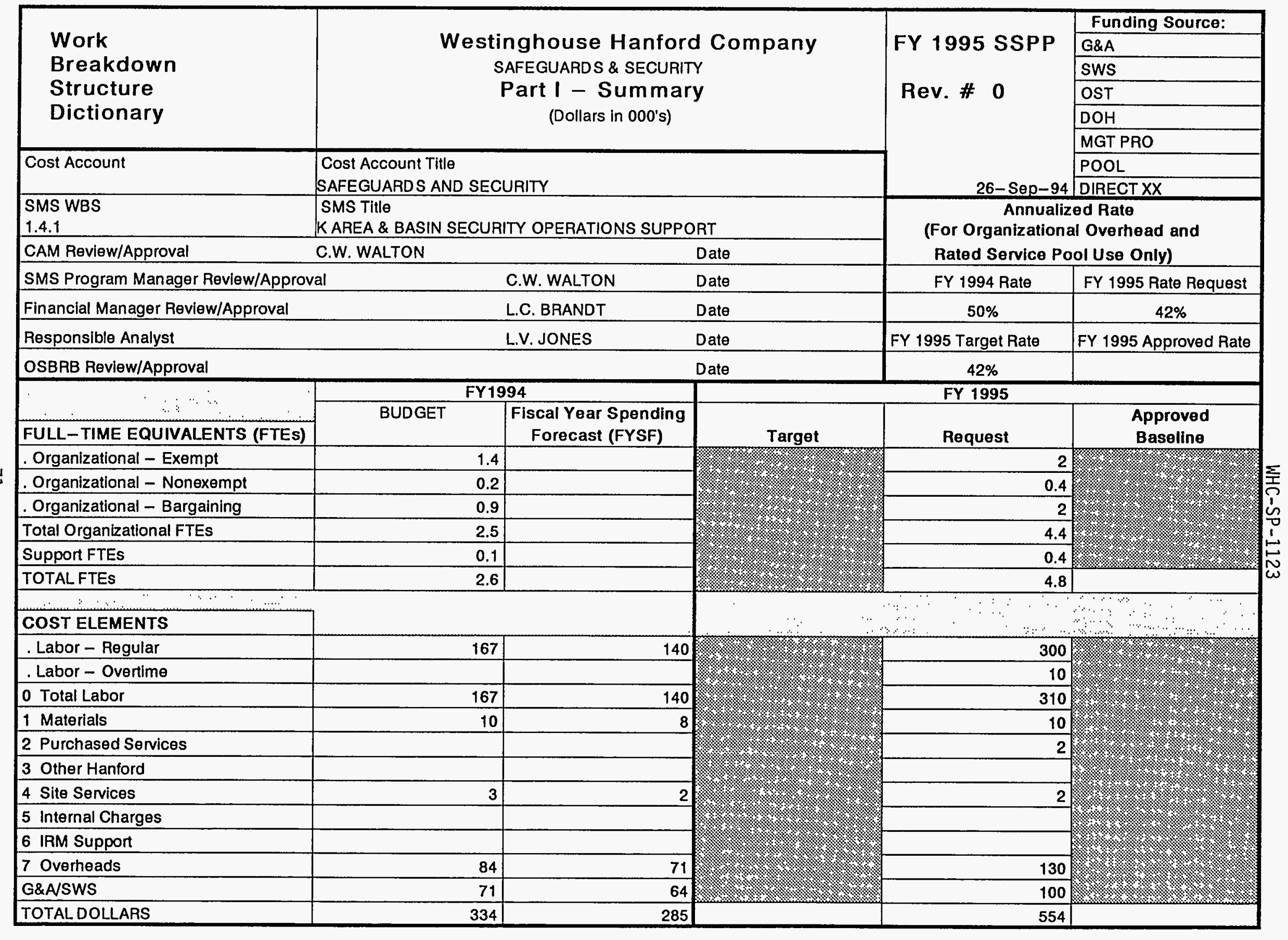




\section{Work Breakdown}

Structure

Dictionary
Westinghouse Hanford Company

Safeguards and Security

Part II - Element Definition
FY 1995 SSSP

Revision \#0

\section{WBS ELEMENT CODE: 1.4 .1}

TITLE: NORTHERN SECURITY OPERATIONS SUPPORT FOR K AREA BASINS

\section{ELEMENT TASK DESCRIPTION}

COST CONTENT - Develop and administer security support for the security systems, preventive maintenance and spare parts program, Projects coordination, physical security issues, key control, and security education.

TECHNICAL CONTENT - According to applicable DOE Orders and Company Directives, provide specialized physical security protection guidance, security educational training, security alarm systems maintenance and testing, software and hardware engineering, and key accountability control.

OBJECTIVES - Provide appropriate staffing levels to support planned K Area enhanced security requirements. Adjust organizational goals to meet site mission changes and to quickly and effectively mitigate radiological sabotage risk levels. Perform maintenance and engineering to retain a safe and cost effective alarm and assessment system through remedial/preventive/enhancement systems programs. Provide specialized security engineering for project designs, planning, and overview support. Coordinate and gain approvals for changes to the security systems, projects, and related facilities. Direct or approve Plant security policy and changes.

ASSUMPTIONS/CONSTRAINTS - K Basins will remain operational for the storage of spent CAT II nuclear fuel and, pending approval of State and EIS documentation submittals, planning and direction will continue for cask encapsulation. Planning and engineering will be directed towards major enhancements of the Basins' intrusion detection and denial systems. The existing Limited Areas and interior sensor systems will be retained, but must operate more effectively than in past years with minimal nuisance and false alarms. Budgeting complexities and documentation will required greater time and support. Mitigation of all security concerns must be enacted more promptly than in past years.

MILESTONES - Support the K Basins' milestone for development of a facility Life-extension upgrade plan during FY95 which will significantly reduce the Program's long term direct SAS costs. 


\begin{tabular}{|l|c|c|}
\hline \multicolumn{1}{|c|}{ COST ACCOUNT } & \multicolumn{2}{|c|}{ FY 1995 SSSP } \\
\hline $\begin{array}{l}\text { Work Breakdown } \\
\text { Structure }\end{array}$ & Westinghouse Hanford Company & Revision \#0 \\
Dictionary & Safeguards and Security & Part - Element Definition \\
\hline
\end{tabular}

\begin{tabular}{|l|l|}
\hline WBS ELEMENT CODE: 1.4 .1 & $\begin{array}{l}\text { TITLE: NORTHERN SECURITY OPERATIONS SUPPORT FOR K AREA } \\
\text { BASINS }\end{array}$ \\
\hline ELEMENT TASK DESCRIPTION \\
DELIVERABLES - Provide a comprehensive total physical security program to support the K Areas and Basin operations, \\
including security maintenance, software support, engineering, systems testing, key control, and security education. \\
Ten year Security Education Staff Meeting Assistance Briefing. \\
Zero percent backlog on PM's. \\
$100 \%$ accountability of keys for K-Basins. \\
Zero percent of backlog on priority II work requests. \\
\end{tabular}




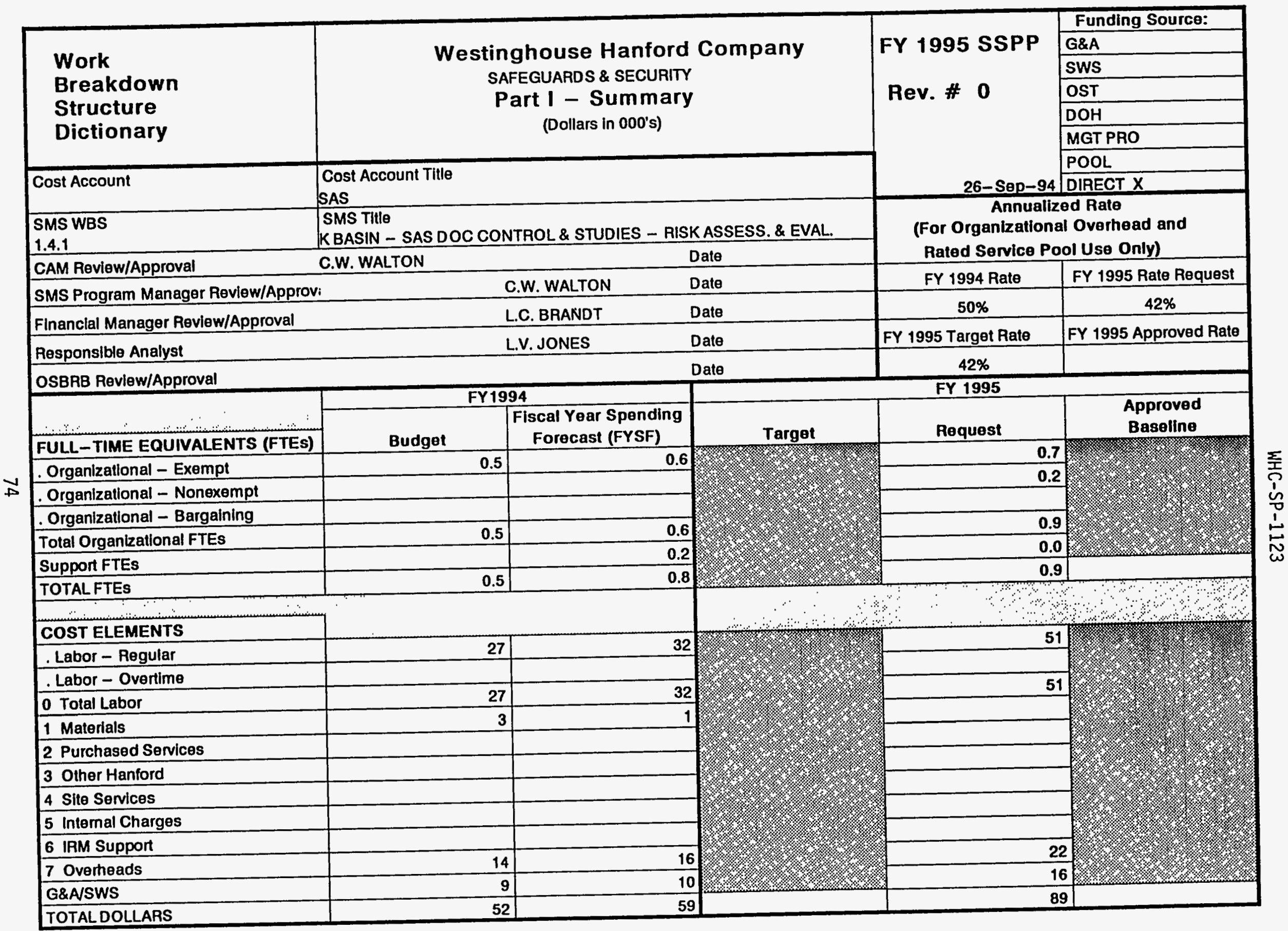




\begin{tabular}{|l|c|c|}
\hline \multicolumn{1}{|c|}{ COST ACCOUNT } & \multicolumn{2}{|c|}{ Westinghouse Hanford Company } \\
\hline $\begin{array}{l}\text { Work Breakdown } \\
\text { Structure } \\
\text { Dictionary }\end{array}$ & Safeguards \& Security & Revision \#0 \\
\hline
\end{tabular}

\begin{tabular}{|l|l|}
\hline WBS ELEMENT CODE: 1.4 .1 & TITLE: K BASINS - SAS DOC CONTROL \& STUDIES \\
\hline ELEMENT TASK DESCRIPTION &
\end{tabular}

ELEMENT TASK DESCRIPTION

COST CONTENT -

Direct funding from K-Basin.

\section{TECHNICAL CONTENT -}

Update and finalize the K-Bas in Vulnerability Analys is Report (VAR) and Safeguards and Security Management Report (SSMR) for inclusion into the Hanford Site SSSP. Complete the upgrade evaluation, validation testing and facility upgrade implementation. Regulatory drivers that impact the element are DOE 5630.14A "Safeguards and Security Program P1anning," DOE 5630.13A "Master Safeguards and Security Agreements," and DOE N 5630.3A "Protection of Departmental Facilities against Radiological and Toxicological Sabotage.

\section{OBJECTIVES -}

To update the K-Basin VAR report to include the upgrade evaluation for FY 1995 . To update and complete the SSMR for FY 1995. To conduct validation testing of detection, delay, and response elements. To update risk results and verify radiological consequence values.

\section{ASSUMPTIONS/CONSTRAINTS -}

VAR and SSMR as primary parts of the Hanford Site Safeguards and Security Plan will be updated based on Category II SNM holdings and radiological/toxicological sabotage interests at the facility.

\section{MILESTONES -}

Upgrade evaluation, implementation and validation testing to be completed by September 1994 . VAR and SSMR update for FY 1995 are to be completed by September 1995.

\section{DELIVERABLES -}

Upgrade Evaluation report - February 1995

FY 1995 VAR - September 1995

FY 1995 SSMR - September 1995 


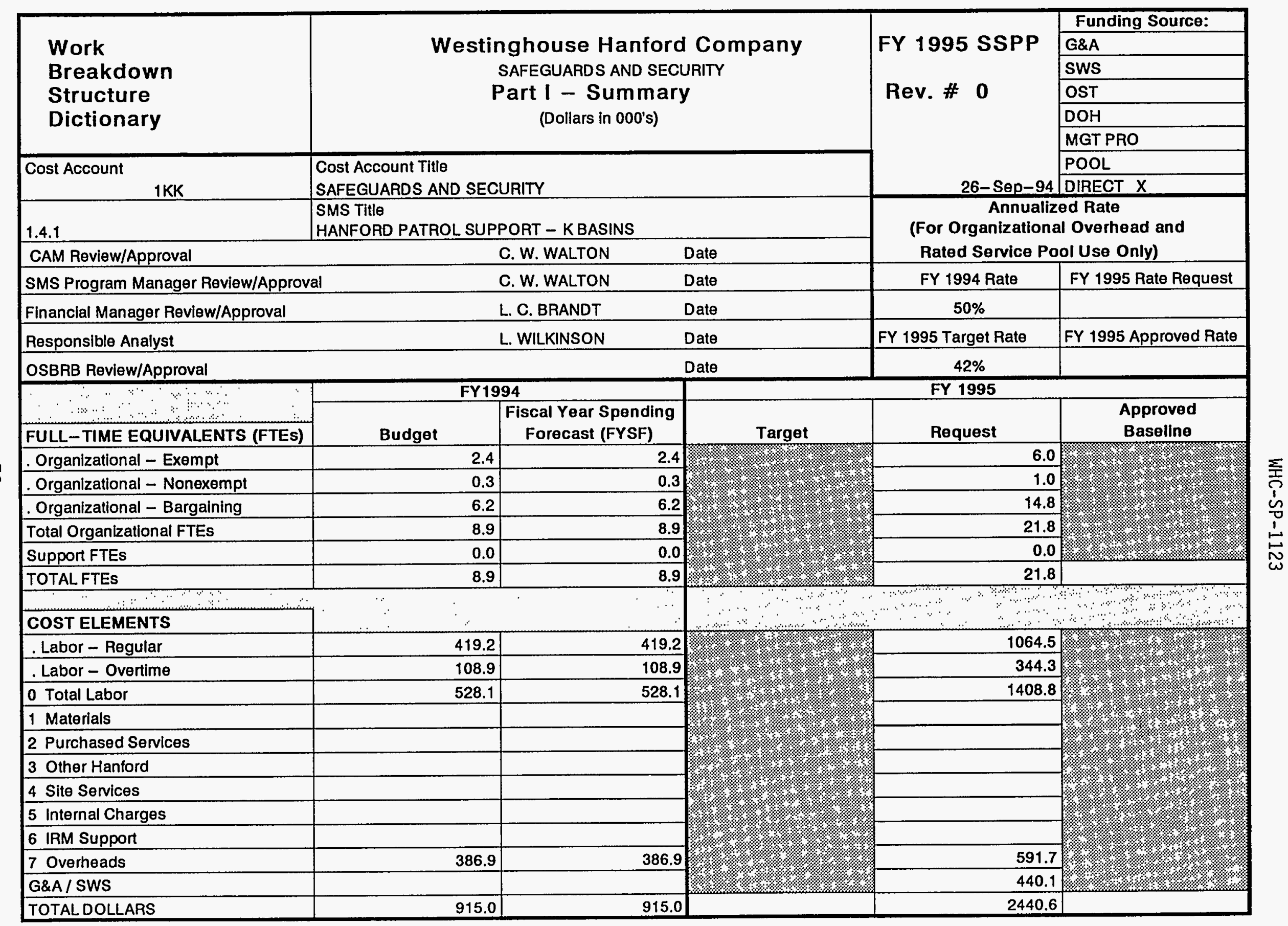


COST ACCOUNT

Work Breakdown

Structure

Dictionary

Westinghouse Hanford Company Safeguards and Security Part II - Element Definition
FY 1995 SSPP

Revision \#0

\begin{tabular}{|l|l|l}
\hline WBS ELEMENT CODE & 1.4 .1 & TITLE: Hanford Patrol \\
\hline
\end{tabular}

ELEMENT TASK DESCRIPTION

COST CONTENT -

This activity is funded by the Spent Nuclear Fuels Program.

TECHNICAL CONTENT -

Provide a professional protective force that is highly trained and effective in techniques for physical protection, emergency response, and public service. Support for K-Basins includes 24-hour surveillance and response by 2 protective force rovers. Support and provide 24 hour access control for six months by Protective Force. Secondary response is provided by the SRT. The Program is also allocated a portion of Shift Commander, Shift Lieutenant, PTA, and POC

support.

DOE Order 5632.7 - Protective Forces

D0E Order 5631.1A - Protection Program Operation

DOE Order 5632.1C - Protection and Control of Safeguards and Security Interests

\section{OBJECTIVES -}

Physically protect Special Nuclear Material, classified information, U.S. Government property, and personnel as a service to $K$ Basins.

\section{ASSUMPTIONS/CONSTRAINTS -}

The Patrol force will continue to be responsible to respond to and control any incident that threatens 1 ife or property on the Site until relieved by other authority.

\section{MILESTONES -}




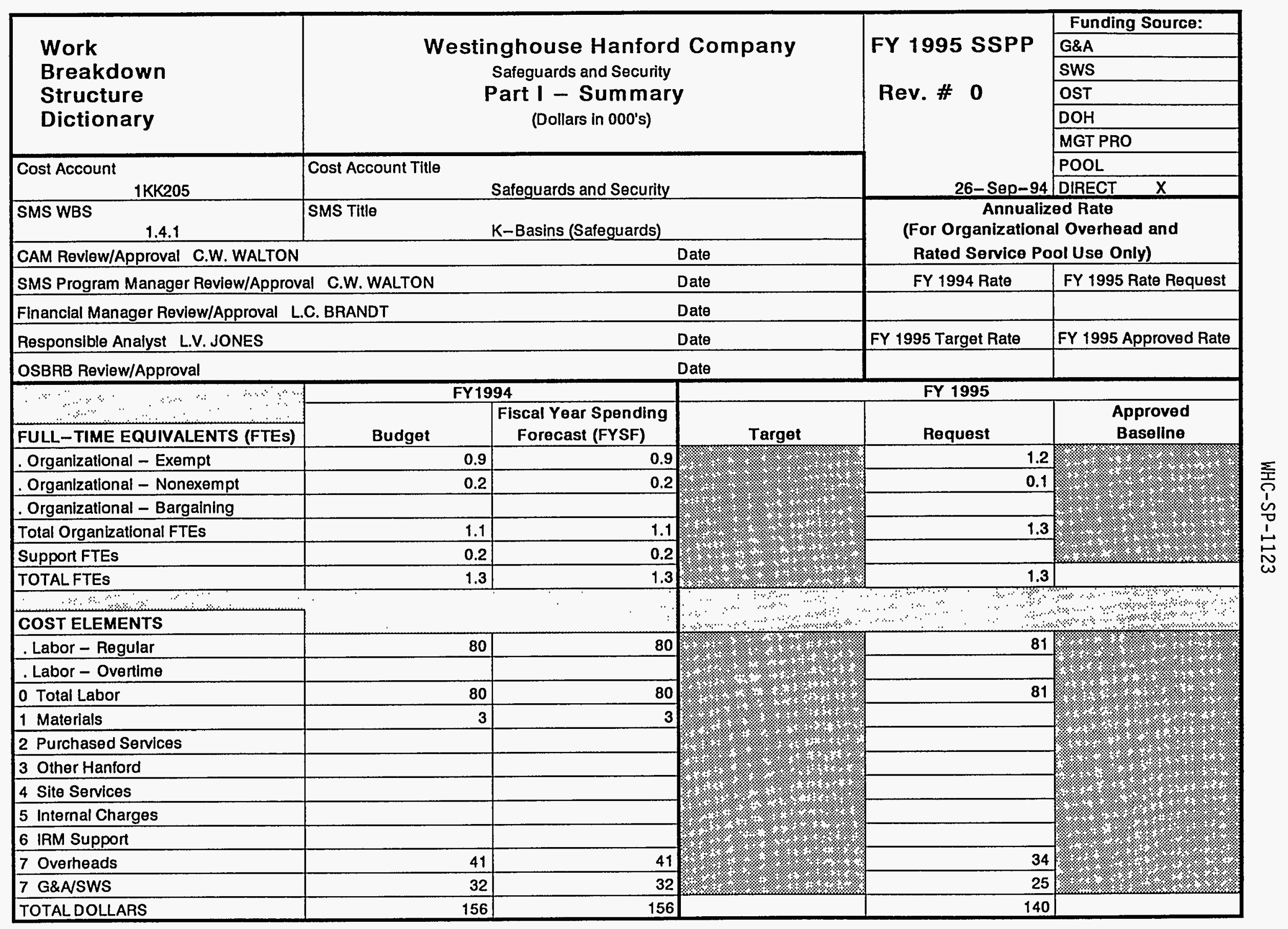




\begin{tabular}{|l|c|c|}
\hline \multicolumn{1}{|c|}{ 1KK205 } & & FY 1995 SSPP \\
\hline $\begin{array}{l}\text { Wost ACCOUNT } \\
\text { Structure } \\
\text { Dictionary }\end{array}$ & Westinghouse Hanford Company & Revision \# 0 \\
\hline
\end{tabular}

\begin{tabular}{|l|l|}
\hline WBS ELEMENT CODE: $\quad 1.4 .1$ & TITLE: $\quad$ K-Basins (Safeguards) \\
\hline ELEMENT TASK DESCRIPTION
\end{tabular}

ELEMENT TASK DESCRIPTION

\section{COST CONTENT -}

This element is funded by the $\mathrm{K}-\mathrm{Basin}$ project.

\section{TECHNICAL CONTENT -}

This element is responsible for developing, maintaining, and implementing policies and procedures governing the use, control and accountability of nuclear materials in confomance with DOE orders. Regulatory drivers that impact the element are DOE 5633.3A, "Control and Accountability of Nuclear Materials", DOE 5633.4, "Nuclear Materials Transactions: Documentation and Reporting", DOE 5633.5, "Nuclear Materials Reporting and Data Submission Procedures", and RLID 5633.3A, "Control and Accountability of Nuclear Materials at Richland Operations Office".

\section{OBJECTIVES -}

The element will control and account for WHC nuclear materials in a manner that meets the requirements of federal and state regulations, DOE Orders, safety and environmental compliance requirements, and other WHC company policies. In addition, the element will proactively identify MC\&A issues, develop workable solutions, and follow through on implementation of solutions.

\section{ASSUMPTIONS/CONSTRAINTS -}

None

\section{MILESTONES -}

None

\section{DELIVERABLES -}

- Monthly and quarterly nuclear material reports for RL Safeguards and RL Programs

- MC\&A training records including course completion rosters, custodian authorizations, OJT checklists, and exams

- NMMSS transaction and inventory data

- Physical inventory records including schedules, inventory plans, releases to resume activities, signed PRE-416 reports, and RL-430 certification forms

- RL Survey questionnaire

- Quarterly report from historical inventory difference database 


\section{Part II - Element Definition (continued)}

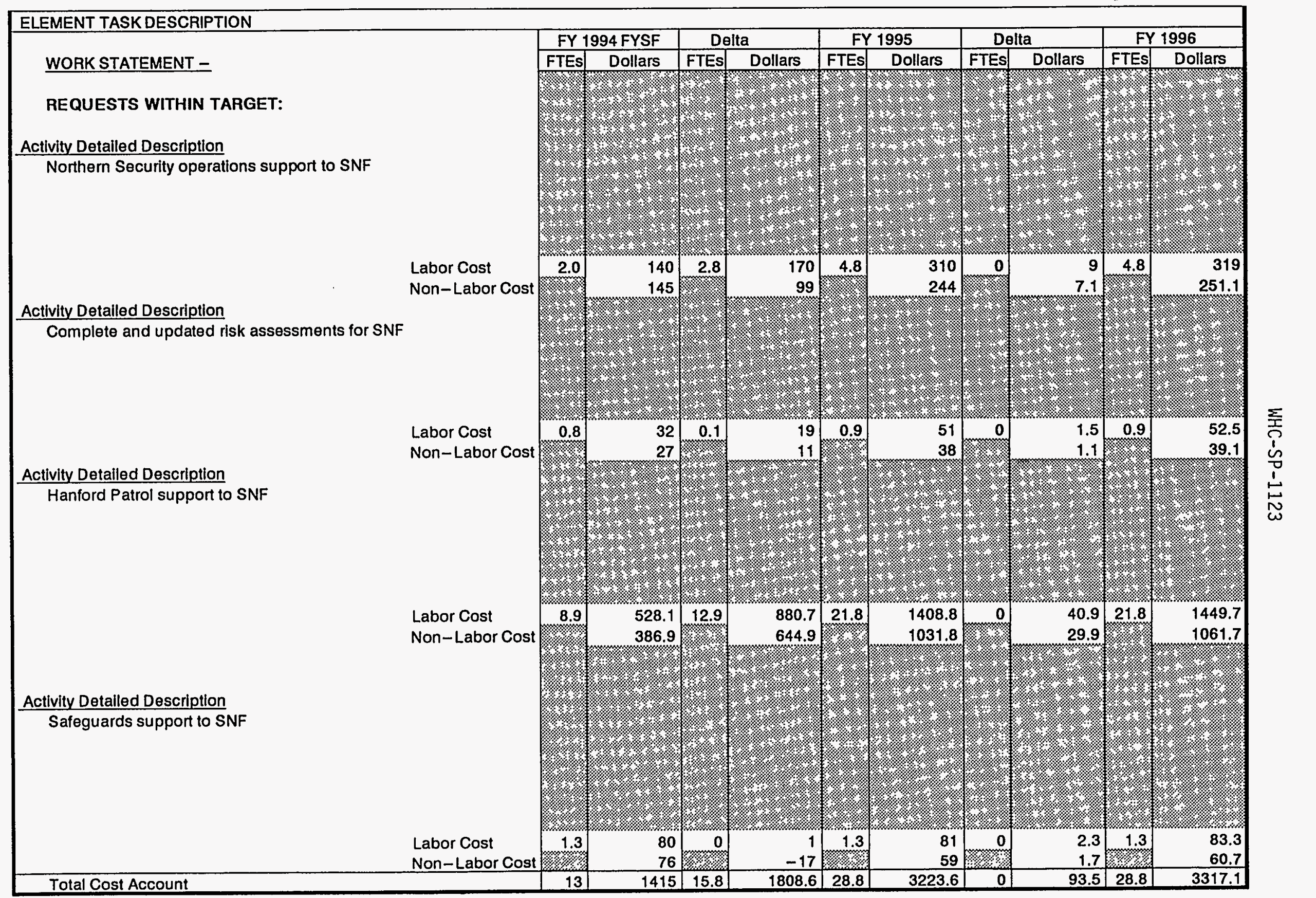




\begin{tabular}{|c|c|c|c|c|c|}
\hline \multirow{5}{*}{$\begin{array}{l}\text { Work } \\
\text { Breakdown } \\
\text { Structure } \\
\text { Dictionary }\end{array}$} & \multirow{4}{*}{\multicolumn{3}{|c|}{$\begin{array}{l}\text { Westinghouse Hanford Company } \\
\text { SAFEGUARDS AND SECURITY } \\
\text { Part I - Summary }\end{array}$}} & \multirow{7}{*}{$\begin{array}{l}\text { FY } 1995 \text { SSPP } \\
\text { Rev. \# } 0\end{array}$} & Funding Source: \\
\hline & & & & & G\&A \\
\hline & & & & & SWS \\
\hline & & & & & OST \\
\hline & \multicolumn{3}{|c|}{$\begin{array}{c}\text { Part I - Summary } \\
\text { (Dollars in 000's) }\end{array}$} & & $\mathrm{DOH}$ \\
\hline Cost Account & \multirow{2}{*}{\multicolumn{3}{|c|}{$\begin{array}{l}\text { Cost Account Title } \\
\text { SAFEGUARDS AND SECURITY SUPPORT TRANSITION PROJECTS }\end{array}$}} & & \begin{tabular}{|l|} 
MGT PRO \\
POOL
\end{tabular} \\
\hline & & & & & DIRECT $X X$ \\
\hline \begin{tabular}{|r|} 
SMS WBS \\
7.1.6.2.01 \\
\end{tabular} & \multicolumn{3}{|c|}{$\begin{array}{l}\text { SMS Title } \\
\text { SAFEGUARDS AND SECURITY }\end{array}$} & \multirow{2}{*}{\multicolumn{2}{|c|}{$\begin{array}{l}\text { Annualized Rate } \\
\text { (For Organizational Overhead and } \\
\text { Rated Service Pool Use Oniy) }\end{array}$}} \\
\hline \multicolumn{2}{|l|}{ CAM Revlew/Approval C.W. WALTON } & \multirow{2}{*}{\multicolumn{2}{|c|}{$\frac{\text { Date }}{\text { Date }}$}} & & \\
\hline \multicolumn{2}{|c|}{ SMS Program Manager Review/Approval $\quad$ C.W. WALTON } & Date & & FY 1994 Rate & FY 1995 Rate Request \\
\hline \multicolumn{2}{|c|}{ Financial Manager Review/Approval $\quad$ L.C. BRANDT } & \multicolumn{2}{|r|}{ Date } & $50 \%$ & \\
\hline \multicolumn{2}{|l|}{ Responsible Analyst L.V. JONES } & \multicolumn{2}{|r|}{ Date } & FY 1995 Target Rate & FY 1995 Approved Rate \\
\hline \multicolumn{2}{|l|}{ OSBRB Review/Approval } & \multicolumn{2}{|c|}{ Date } & $42 \%$ & \\
\hline$\therefore \quad \ldots \ldots$ & \multicolumn{2}{|c|}{ FY1994 } & \multicolumn{3}{|c|}{ FY 1995} \\
\hline \begin{tabular}{|l|} 
FULL-TIME EQUIVALENTS (FTES) \\
\end{tabular} & Budget & \begin{tabular}{|c|}
$\begin{array}{c}\text { Fiscal Year Spending } \\
\text { Forecast (FYSF) }\end{array}$ \\
\end{tabular} & Target & Request & $\begin{array}{l}\text { Approved } \\
\text { Baseline }\end{array}$ \\
\hline \multicolumn{6}{|l|}{. Organizational - Exempt } \\
\hline \multicolumn{6}{|l|}{. Organizational - Nonexempt } \\
\hline \multicolumn{6}{|l|}{. Organizational - Bargaining } \\
\hline \multicolumn{6}{|l|}{ Total Organizational FTEs } \\
\hline \multicolumn{6}{|l|}{ Support FTEs } \\
\hline TOTALFTES & 18.1 & 13.2 & ২: & 11.9 & \\
\hline Bum & & $\therefore$ & $\therefore \quad \therefore \quad \cdots$ & $\therefore$ & on \\
\hline COST ELEMENTS & & & 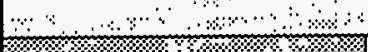 & $\therefore \quad-1$ & m: \\
\hline Labor - Regular & & & 16: & 722 & $1 \%$ \\
\hline Labor - Overtime & & & & 10 & \\
\hline 0 Total Labor & 873 & 으 & \% & 732 & \\
\hline 1 Materials & 50 & & 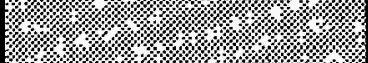 & 35 & \\
\hline 2 Purchased Senvices & 66 & & (1) & 56 & \\
\hline 3 Other Hanford & 0 & & 1/1: & 5 & \\
\hline 4 Site Services & 19 & & (1) & 13 & \\
\hline 5 Internal Charges & 0 & & (1) & & \\
\hline 6 IRM Support & 24 & & 14: & 10 & \\
\hline 7 Overheads & 465 & & ' & 313 & \\
\hline G\&A/SWS & 397 & & 1.:. & 256 & \\
\hline TOTALDOLLARS & 1,893 & 1,563 & & 1,420 & \\
\hline
\end{tabular}




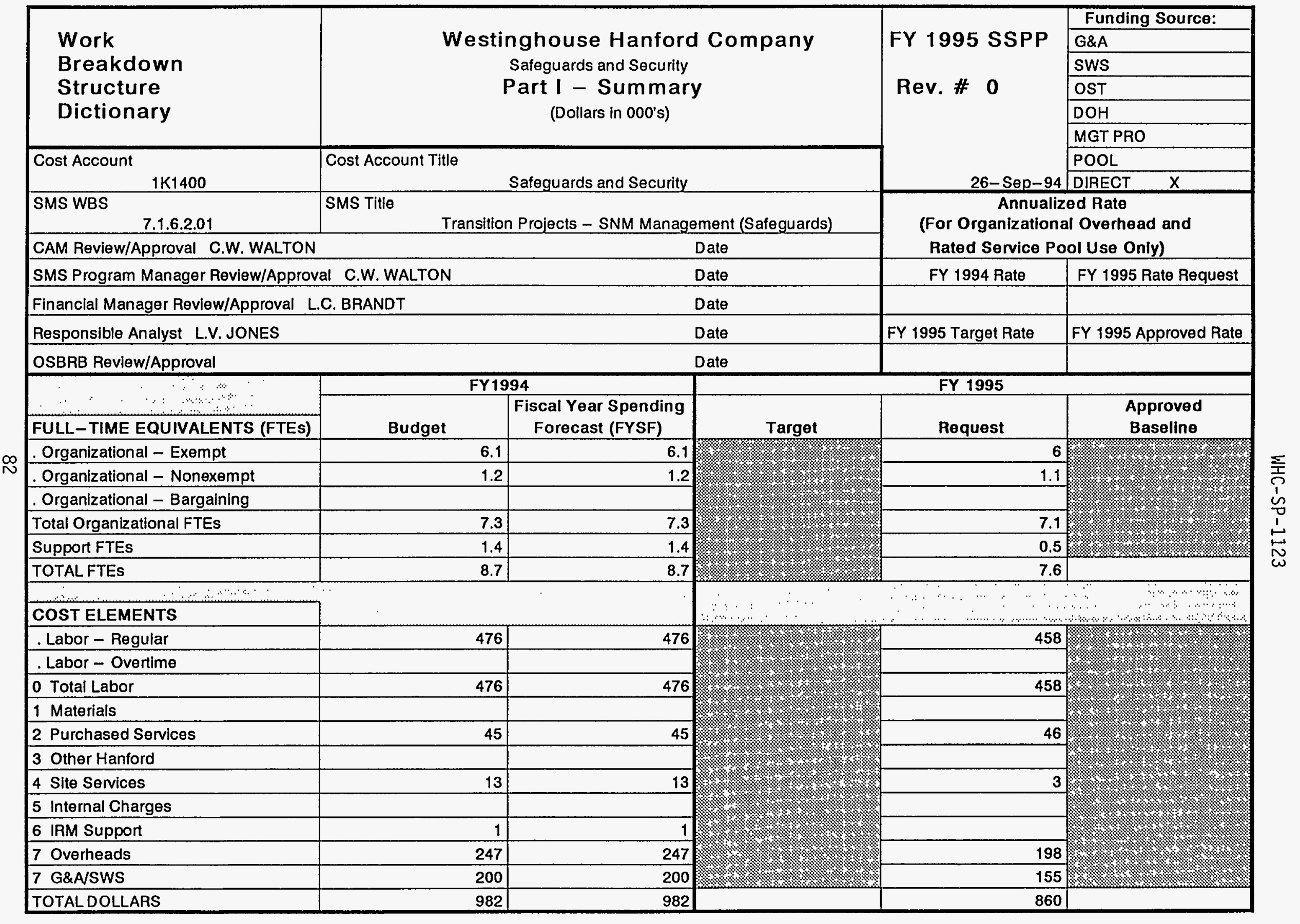




\begin{tabular}{|l|c|c|}
\hline \multicolumn{1}{|c|}{\begin{tabular}{|c|} 
1K1400 \\
Cost ACcouNT
\end{tabular}} & FY 1995 SSPP \\
\hline $\begin{array}{l}\text { Work Breakdown } \\
\begin{array}{l}\text { Structure } \\
\text { Dictionary }\end{array}\end{array}$ & Westinghouse Hanford Company \\
\hline
\end{tabular}

\begin{tabular}{|c|c|c|c|}
\hline WBS ELEMENT CODE: & 7.1.6.2.01 & TITLE: & Transition Projects - SNM Management (Safeguards) \\
\hline
\end{tabular}

\section{TECHNICAL CONTENT -}

This element is responsible for developing, maintaining, and implementing policies and procedures governing the use, control and accountability of nuclear materials in confomance with DOE orders. Regulatory drivers that impact the element are DOE 5633.3A, "Control and Accountability of Nuclear Materials", DOE 5633.4, "Nuclear Materials Transactions: Documentation and Reporting", DOE 5633.5, "Nuclear Materials Reporting and Data Submission Procedures", and RLID 5633.3A, "Control and Accountability of Nuclear Materials at Richland Operations Office".

\section{OBJECTIVES -}

The element will control and account for WHC nuclear materials in a manner that meets the requirements of federal and state regulations, DOE Orders, safety and environmental compliance requirements, and other WHC company policies. In addition, the element will proactively identify MC\&A issues, develop workable solutions, and follow through on implementation of solutions.

\section{ASSUMPTIONS/CONSTRAINTS -}

The current NM accounting system will be maintained until a replacement system is avallable.

There will be no significant additions or reductions to special nuclear material inventories due to recelpts or removals.

\section{MILESTONES -}

Implement Safeguards training program fully compliant to DOE Order 5630.15 requirement by August 22, 1995. (Stretch Goal - May 22, 1995)

Participate in revlews of LANMAS core design efforts under way at Los Alamos by reviewing documents produced and attending quarterly review meetings. Level of effort through September 1995.

Complete study and document contingency plan(s) for Nuclear Materials Accounting System by January 31, 1995.

As requested by RL, prepare comprehensive, accurate and timely responses to new/revised DOE Orders. Level of effort through September 1995.

Semiannual audits of TID program completed and documented on schedule throughout the fiscal year. (Due 3/31/95 and 9/30/95)

Prepare and submit schedule for 1995 MBA audits by October 15, 1994.

\section{DELIVERABLES -}

- Classified computer system audits

- Material Control and Accountability Plan updates

- Updates to classified computer security plan

- Safeguards deviations to DOE orders

- Monthly Plutonium Discard Limit report

- Materials management infomation as requested

- Material balance area audits 
Work Breakdown

Structure

Dictionary
Westinghouse Hanford Company

Safeguards and Security

Part II - Element Definition
FY 1995 SSSP

Revision \#0

WBS ELEMENT CODE: $\quad 7 \cdot 1 \cdot 6.2 .01$

TITLE: NSO SECURITY OPERATIONS SUPPORT TO TRANSITION FACILITIES AND SNM MANAGEMENT

\section{ELEMENT TASK DESCRIPTION}

COST CONTENT - Develop and administer security support for the Patrol Headquarters security systems and Transition Facilities. This includes maintenance and spare parts programs, engineering, Projects coordination, physical security issues, security key control and educational assistance.

TECHNICAL CONTENT - According to applicable DOE Orders and Company Directives, provide specialized physical security protection guidance, security educational training, security alarm systems maintenance and testing, software and hardware engineering, and key accountability control.

OBJECTIVES - Provide appropriate staffing to support the facilities' security requirements. Adjust organizational goals to meet site mission changes. Perform maintenance and engineering to retain a safe and cost effective alarm monitoring system through remedial/preventive/enhancement security systems programs. Provide specialized security engineering project designs, planning, and overview support. Coordinate approvals for the security system changes, projects and their related facilities, and direct or approve facility RLID access and security policy changes.

ASSUMPTIONS/CONSTRAINTS- The existing Patrol Operations Center will undergo extensive review and testing towards system replacement planning.

MILESTONES - Maintain greater than 98\% security alarm computer system uptime for the Patrol Operations Center (POC).

DELIVERABLES - Provide a cost effective, comprehensive total physical security program support for all Transition Facilities within the 200 Areas and the Patrol Operations Center, including security maintenance, software support, engineering, systems testing, security key control and education. 
WHC-SP-1123

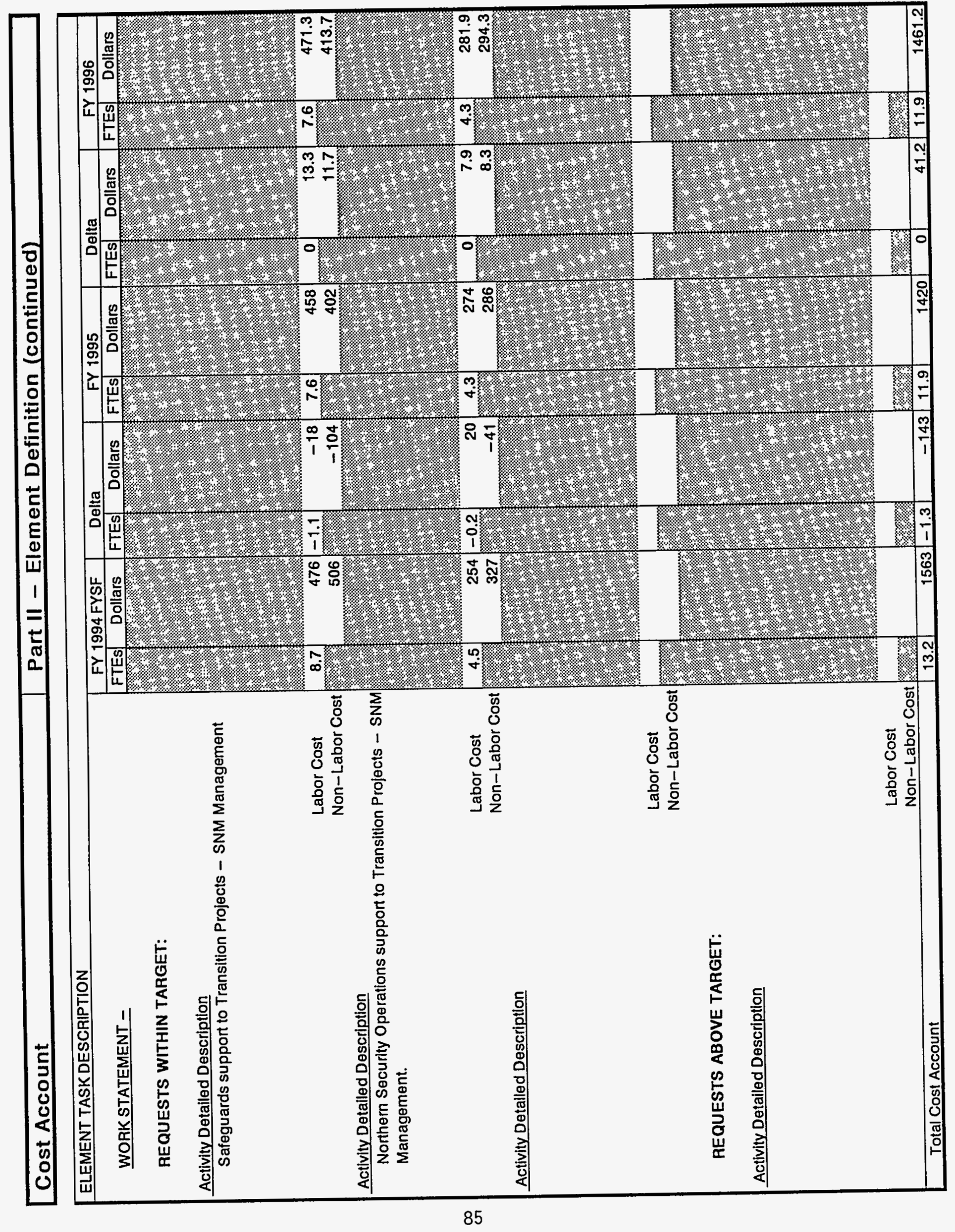




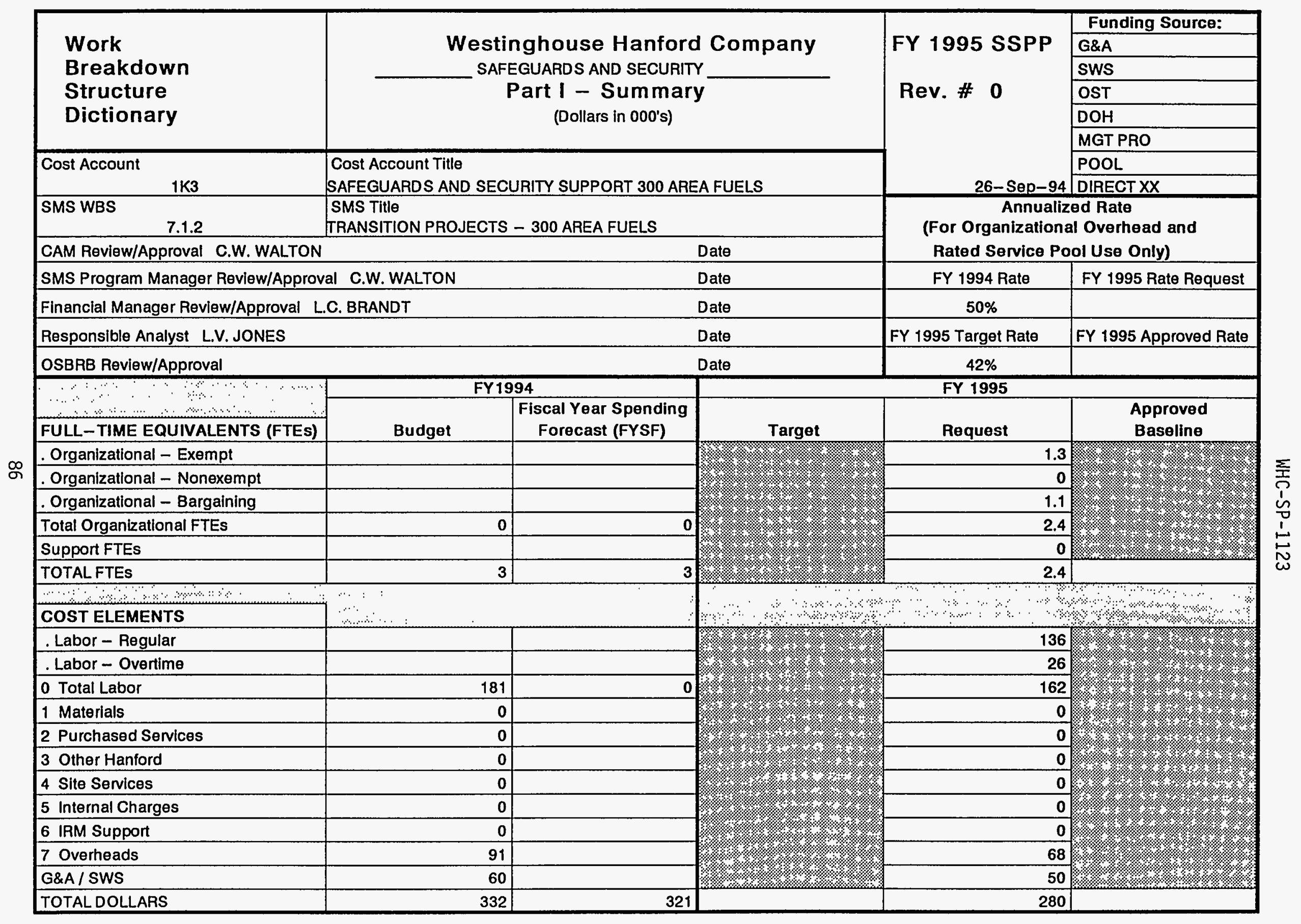




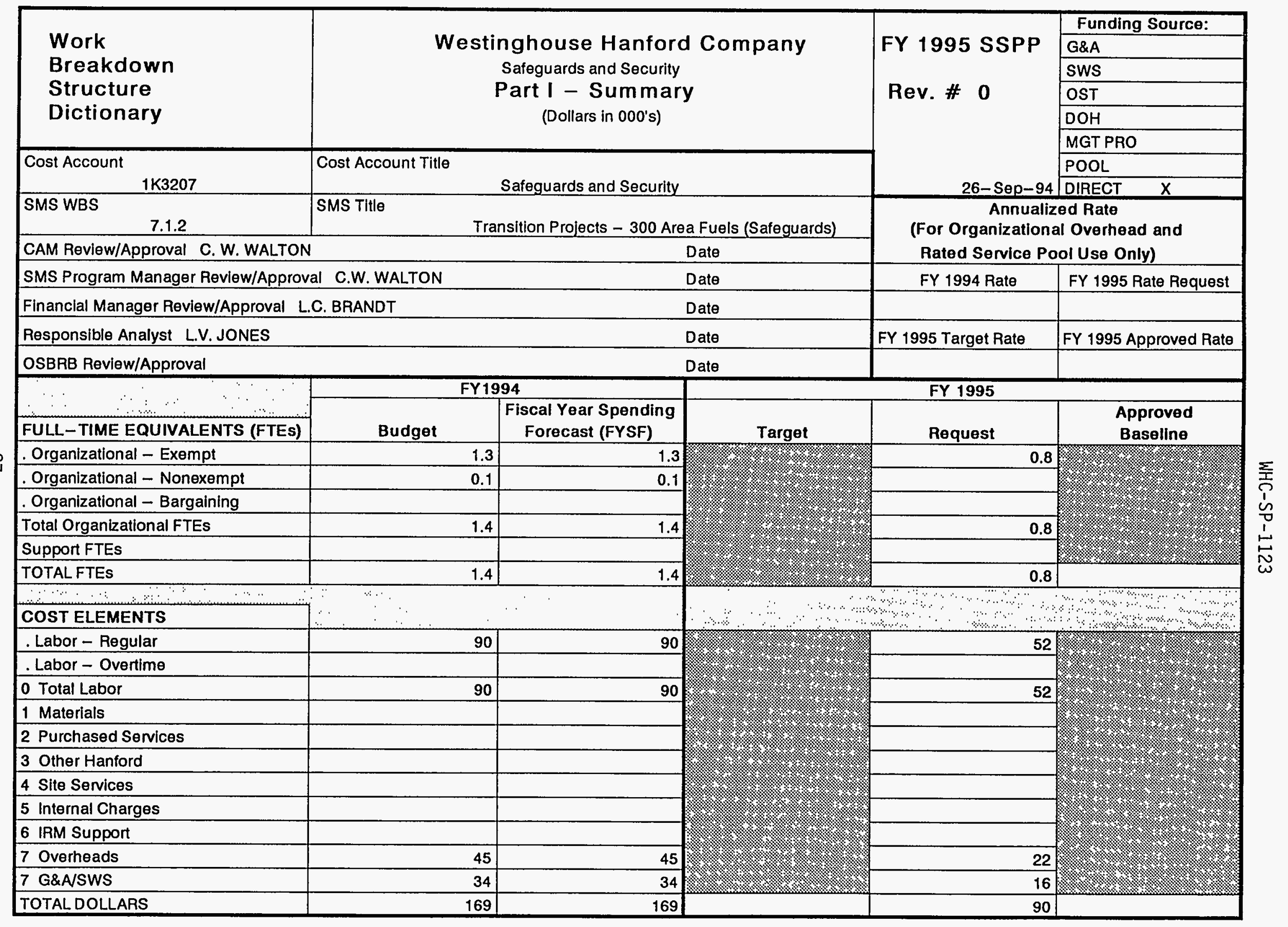




\begin{tabular}{|l|c|c|}
\hline \multicolumn{1}{|c|}{ 1K3207 } & & FY \\
\hline $\begin{array}{l}\text { Work BCcounT } \\
\text { Structure } \\
\text { Dictionary }\end{array}$ & Westinghouse Hanford Company & Safeguards and Security \\
\hline
\end{tabular}

\begin{tabular}{|l|ll}
\hline WBS ELEMENT CODE: $\quad 7.1 .2$ & TITLE: & Transition Projects - 300 Area Fuels (Safeguards) \\
\hline
\end{tabular}

\section{ELEMENT TASK DESCRIPTION} COST CONTENT -

This element is funded by 300 Area Operations. Material control and accountability for the remaining $\mathbf{N}$ Reactor fabrication process fuel is covered by this account.

\section{TECHNICAL CONTENT -}

This element is responsible for developing, maintaining, and implementing policies and procedures governing the use, control and accountability of nuclear materials in conformance with DOE orders. Regulatory drivers that impact the element are DOE 5633.3A, "Control and Accountability of Nuclear Materials", DOE 5633.4, "Nuclear Materials Transactions: Documentation and Reporting", DOE 5633.5, "Nuclear Materials Reporting and Data Submission Procedures", and RLID 5633.3A, "Control and Accountability of Nuclear Materials at Richland Operations Office".

\section{OBJECTIVES -}

The element will control and account for WHC nuclear materials in a manner that meets the requirements of federal and state regulations, DOE Orders, safety and environmental compliance requirements, and ather WHC company policies. In addition, the element will proactively identify MC\&A Issues, develop workable solutions, and follow through on implementation of solutions.

\section{ASSUMPTIONS/CONSTRAINTS -}

Safeguards (MC\&A) will participate, as required, toward a site goal to remove and consolldate excess nuclear materials to the 200 Areas (remove from 300 Area).

\section{MILESTONES -}

\section{None}

\section{DELIVERABLES -}

- Monthly and quarterly nuclear material reports for RL Safeguards and RL Programs

- MC\&A training records including course completion rosters, custodian authorizations, OJT checklists, and exams

- NMMSS transaction and inventory data

- Physical inventory records including schedules, inventory plans, releases to resume activities, signed PRE-416 reports, and RL-430 certification forms

- RL Survey questionnalre

- Quarterly report from historical inventory difference database

- TID records on applications, removals, locations and inventory 


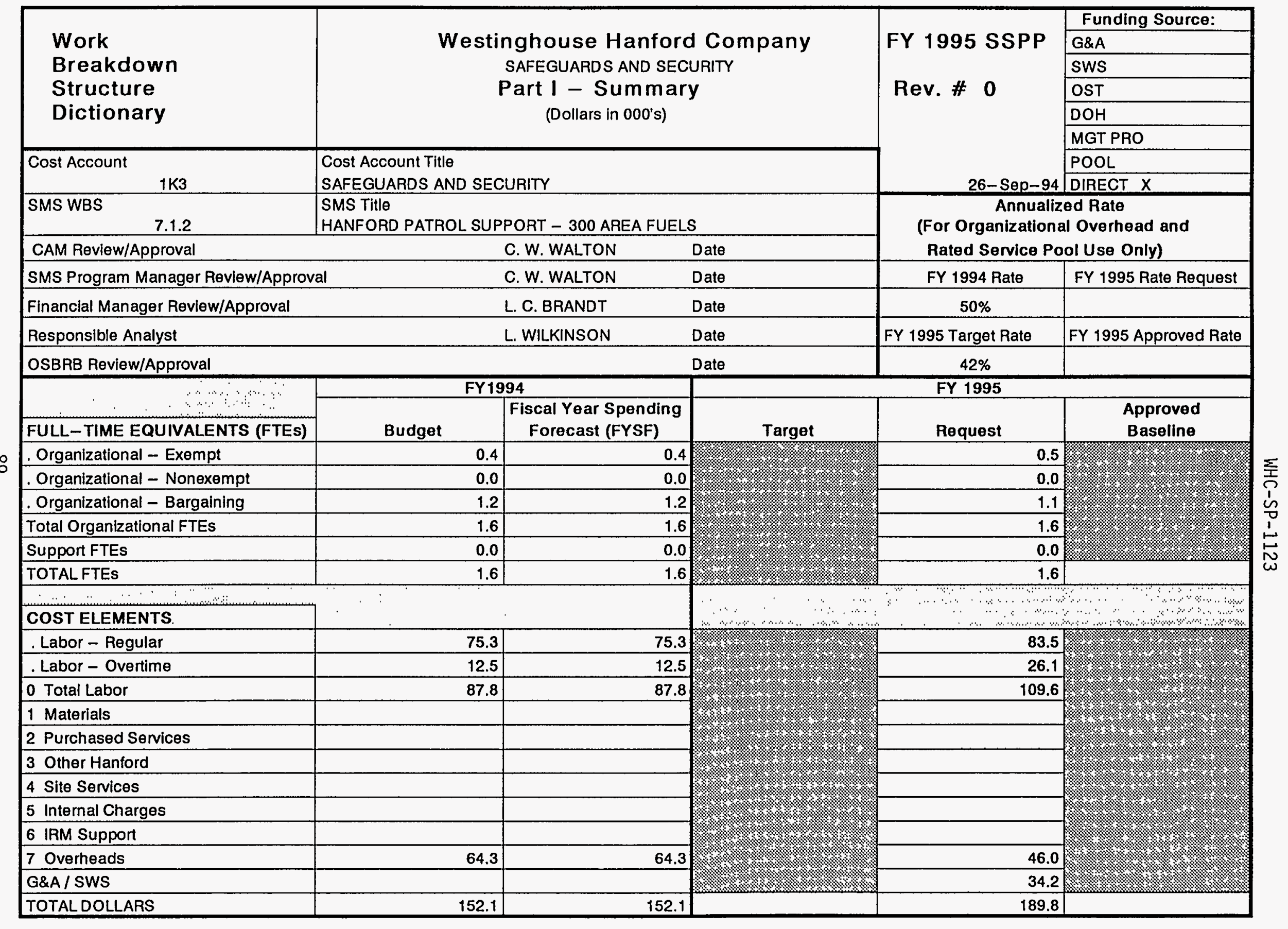


COST ACCOUNT

Work Breakdown

Structure

Dictionary

Westinghouse Hanford Company Safeguards and Security

Part II - Element Definition
FY 1995 SSPP

Revision \#0

\begin{tabular}{|l|l|l}
\hline WBS ELEMENT CODE & 7.1 .2 & TITLE: Hanford Patrol \\
\hline
\end{tabular}

ELEMENT TASK DESCRIPTION

COST CONTENT -

This cost account is funded by the 1K Facility Operations Program and inciudes the 300 Area Fuels.

IECHNICAL CONTENT -

Provide a professional protective force that is highly trained and effective in techniques for physical protection, emergency response, and public service. The support for the Fuels program includes surveillance provided by southern rovers and the Program's allocated portion of the Shift Lieutenant and PTA support.

DOE Order 5632.7 - Protective Forces

DOE Order 5631.1A - Protection Program Operation

DOE Order 5632.1C - Protection and Control of Safeguards and Security Interests

\section{OBJECTIVES -}

Physically protect Special Nuclear Material, classified information, U.S. Government property, and personnel as a service to 300 Area Fuels.

\section{ASSUMPTIONS/CONSTRAINTS -}

The Patrol force will continue to be responsible to respond to and control any incident that threatens 1 ife or property on the Site until relieved by other authority.

\section{MILESTONES -}

DELIVERABLES - 


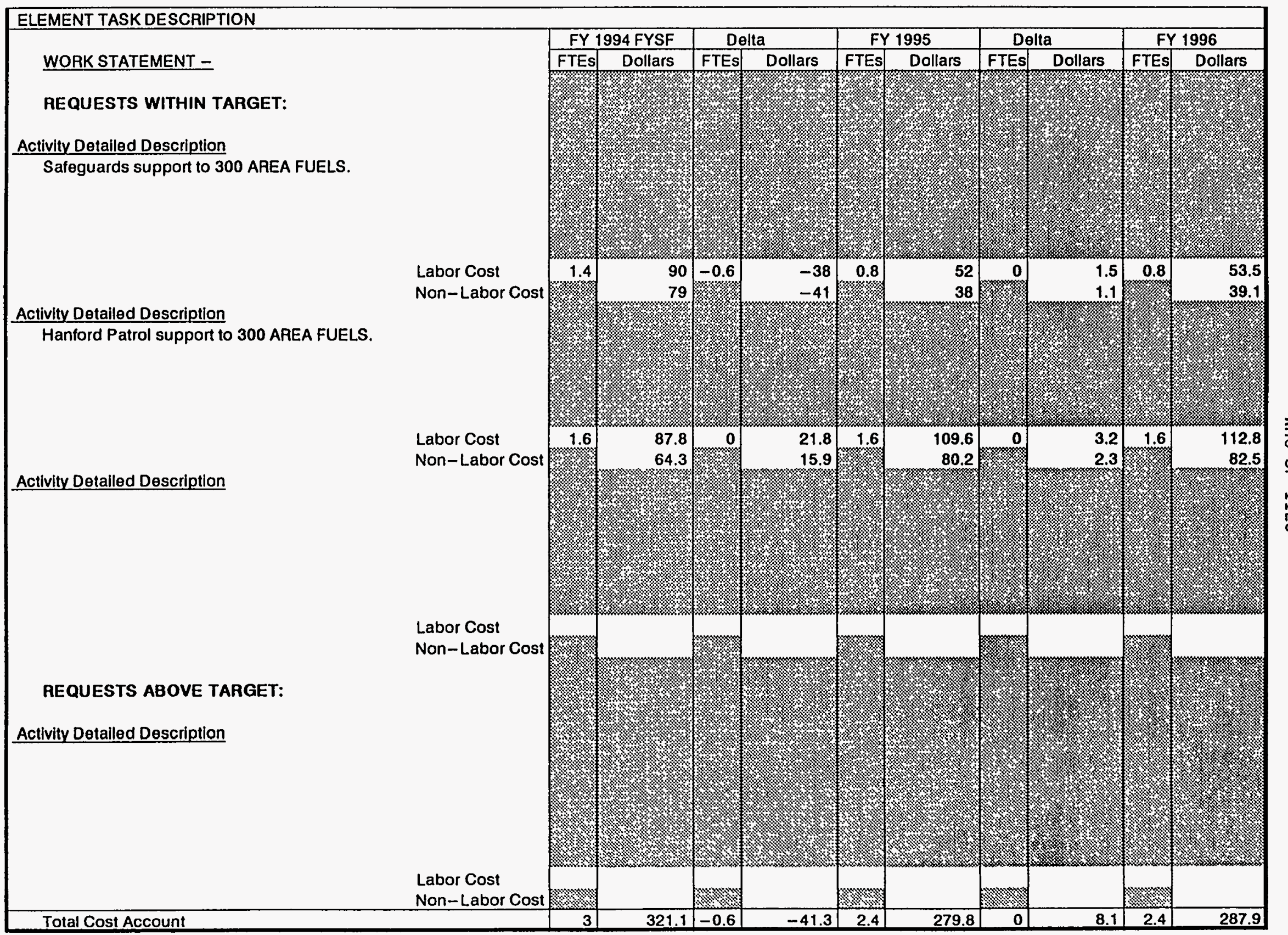




\section{Work \\ Breakdown \\ Structure \\ Dictionary}

\begin{tabular}{|lc|c|}
\hline Cost Account & & \\
& 1KP105 & \\
\hline SMS WBS $\quad 7.1 .1$ & SMS \\
&
\end{tabular}

CAM Review/Approval C.W. WALTON

SMS Program Manager Review/Approval C.W. WALTON

Financial Manager Review/Approval L.C. BRANDT

Responsible Analyst L.V. JONES

OSBRB Review/Approval

N

FULL-TIME EQUIVALENTS (FTES)

. Organizational - Exempt

Organizational - Nonexempt

Organizational - Bargaining

Total Organizational FTEs

Support FTEs

TOTALFTES

Cost Account Title

COST ELEMENTS

. Labor - Regular

- Labor - Overtime

0 Total Labor

1 Materials

2 Purchased Services

3 Other Hanford

4 Site Services

5 internal Charges

6 IRM Support

7 Overheads

7 G\&AVWS

TOTAL DOLLARS
SMS Title

PUREX Support

Transition Projects - PUREX (Safeguards)

Westinghouse Hanford Company

Safeguards and Security

Part I - Summary

(Dollars in 000's) Date

Date

Date

Date

Date

\begin{tabular}{|r|r|}
\hline \multicolumn{3}{|c|}{ FY1994 } \\
\hline Budget & $\begin{array}{l}\text { Fiscal Year Spending } \\
\text { Forecast (FYSF) }\end{array}$ \\
\hline 1.2 & 1.2 \\
\hline & \\
\hline 1.2 & 1.2 \\
\hline 1.2 & 1.2 \\
\hline
\end{tabular}

.2

\begin{tabular}{|r|r|}
\hline 78 & 78 \\
\hline 78 & 78 \\
\hline 5 & 16 \\
\hline 16 & 5 \\
\hline 5 & \\
\hline & 39 \\
\hline 39 & 36 \\
\hline 179 & 179 \\
\hline
\end{tabular}

FY 1995 SSPP

Rev. \# 0

$\frac{10}{P}$

26-Sep-94 DOOL

Annualized Rate

(For Organizational Overhead and Rated Service Pool Use Only)

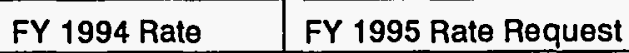

FY 1995 Target Rate FY 1995 Approved Rate

FY 1995

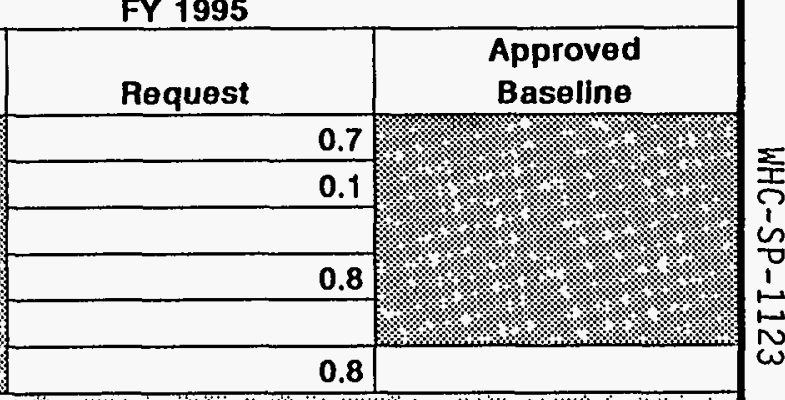

49

49

20

15 


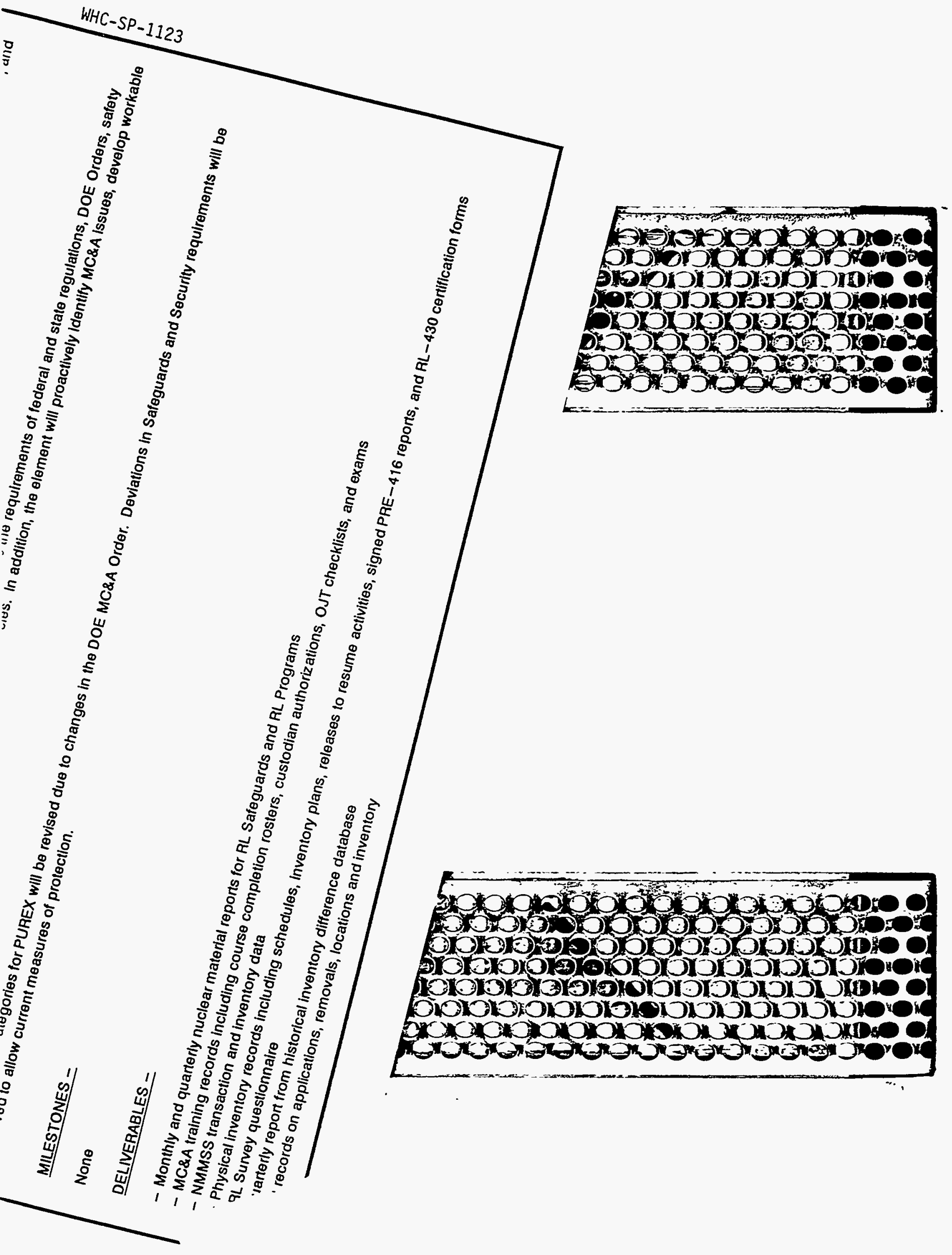




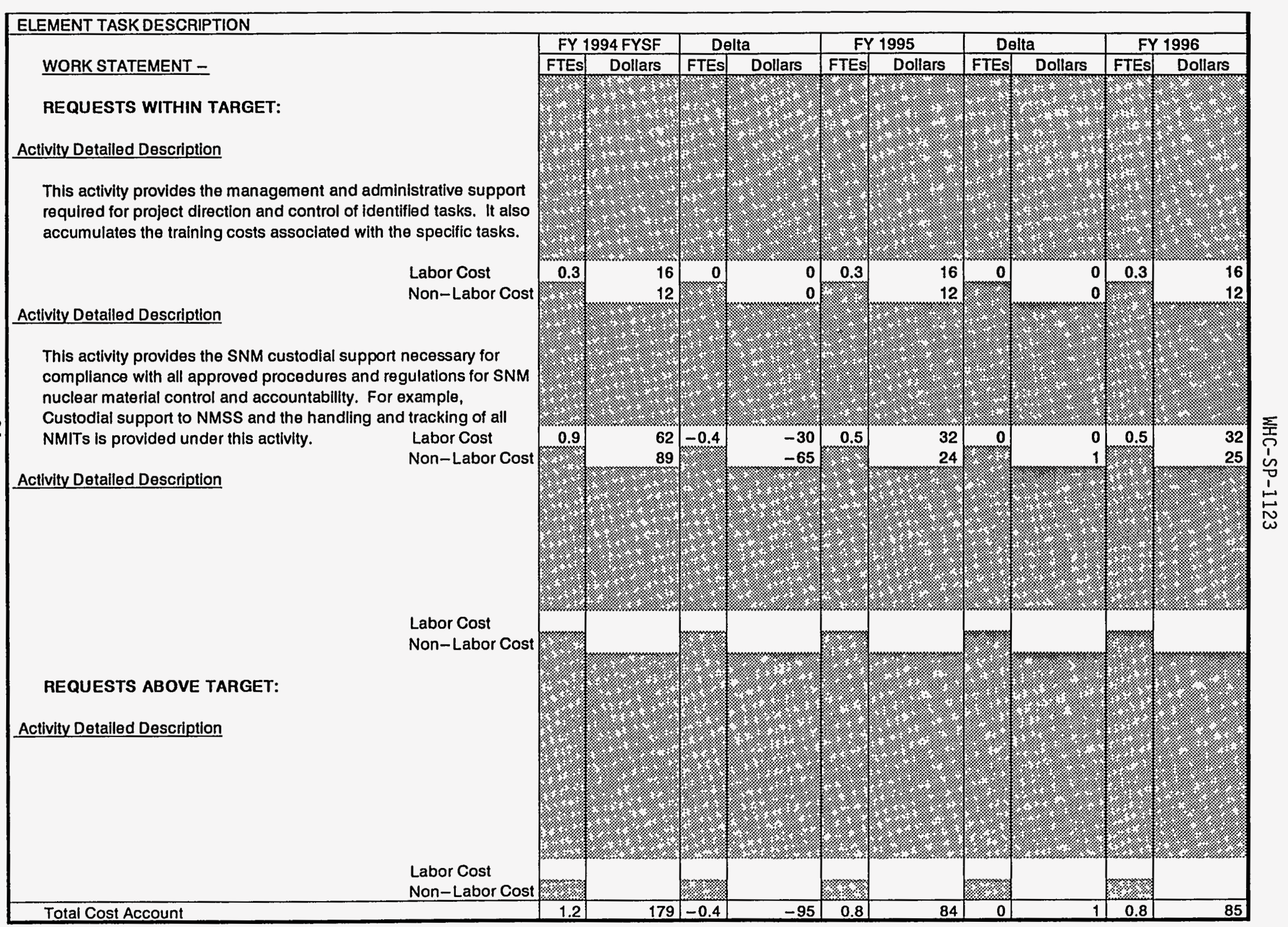




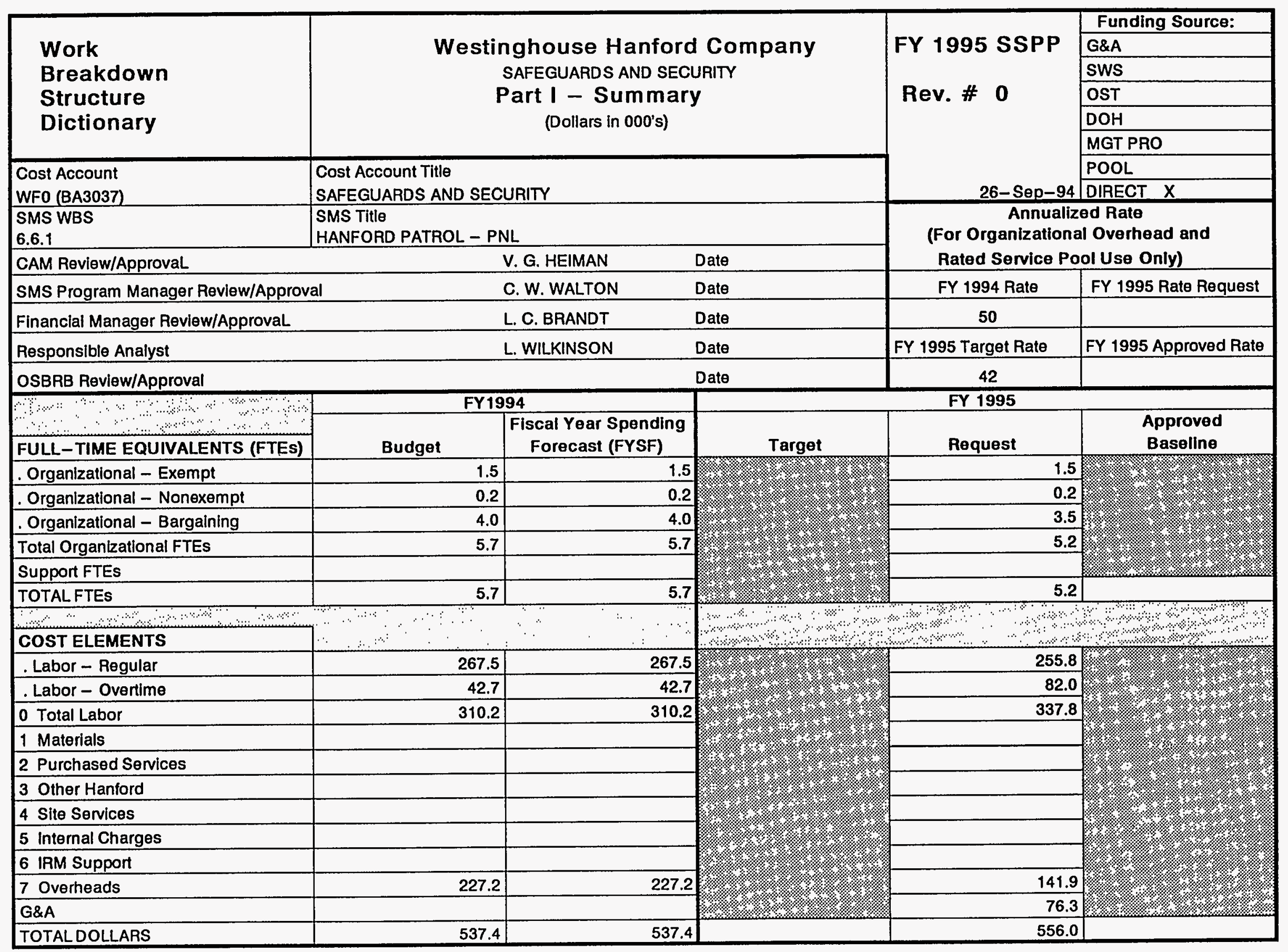


WFO (3037)

COST ACCOUNT

Work Breakdown

Structure

Westinghouse Hanford Company

FY 1995 SSPP

Dictionary Hanford Patrol Part II - Element Definition

\section{Revision \#0}

\begin{tabular}{|l|l|l}
\hline WBS ELEMENT CODE & 6.6 .1 & TITLE: Safeguards and Security
\end{tabular}

ELEMENT TASK DESCRIPTION

COST CONTENT -

Work For Others (WFO) is funded by Pacific Northwest Laboratories (PNL) via work order for Hanford Patrol services. TECHNICAL CONTENT -

Provide a professional protective force that is highly trained and effective in techniques for physical protection, emergency response, and public service. PNL facilities are supported by the southern area rovers and provide 24-hour surveillance along with designated facility checks. PNL is also allocated a portion of the Shift Commander, Shift Lieutenant, PTA, and POC support.

DOE Order 5632.7 - Protective Forces

DOE Order 5631.1A - Protection Program Operation

DOE Order 5632.1C - Protection and Control of Safeguards and Security Interests

\section{OBJECTIVES -}

Physically protect Special Nuclear Material, classified information, U.S. Government property, and personnel as a service to PNL.

\section{ASSUMPTIONS/CONSTRAINTS -}

The Patrol force will continue to be responsible to respond to and control any incident that threatens 1 ife or property on the Site until relieved by other authority.

MILESTONES -

DELIVERABLES - 
Cost Account WFO (BA3037)

Part II - Element Definition (continued)

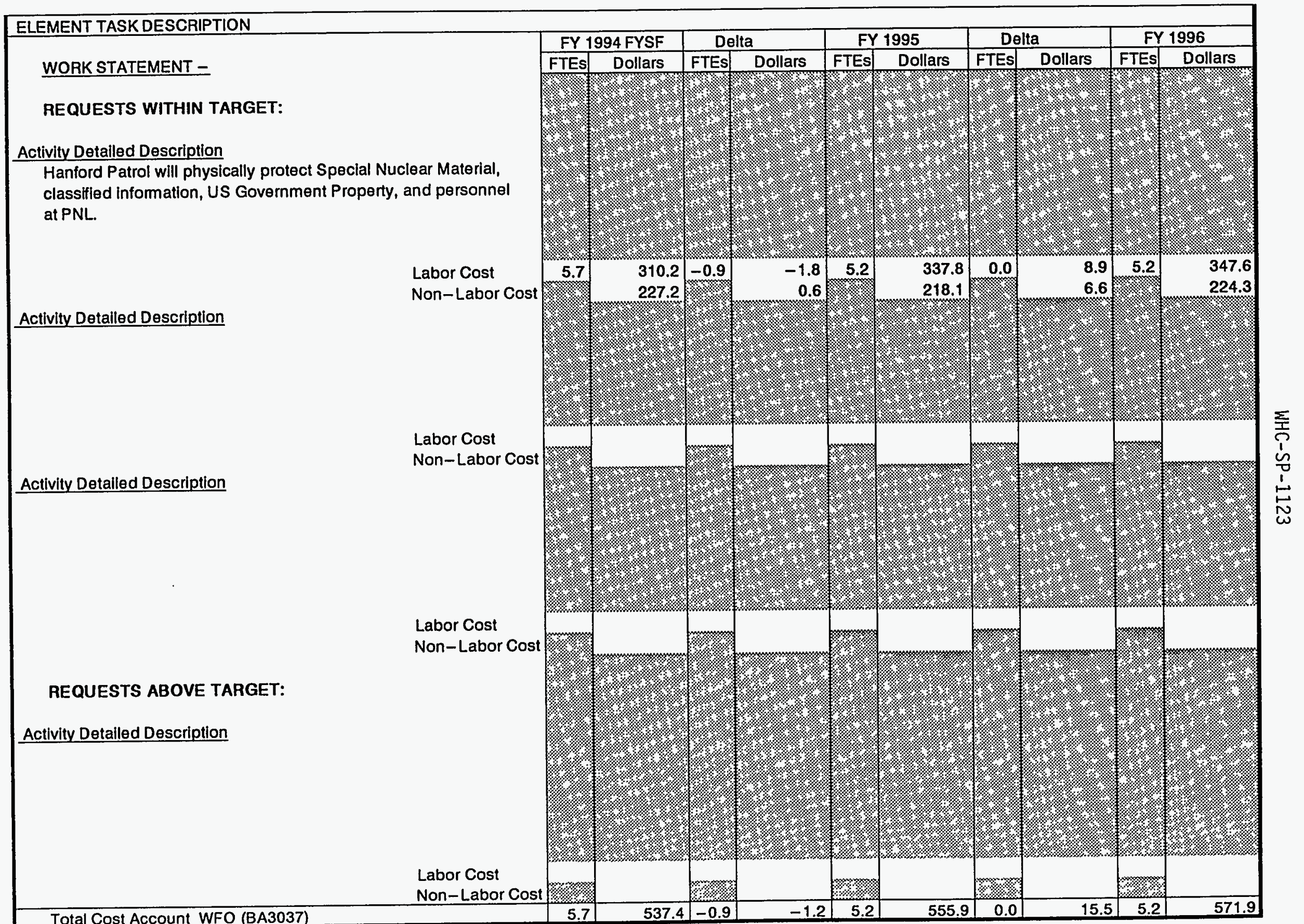




\begin{tabular}{|c|c|c|c|c|c|}
\hline \multirow{6}{*}{$\begin{array}{l}\text { Work } \\
\text { Breakdown } \\
\text { Structure } \\
\text { Dictionary }\end{array}$} & \multirow{6}{*}{\multicolumn{3}{|c|}{$\begin{array}{c}\text { Westinghouse Hanford Company } \\
\text { SAFEGUARDS AND SECURITY } \\
\text { Part I - Summary } \\
\text { (Dollars in 000's) }\end{array}$}} & \multirow{8}{*}{$\begin{array}{r}\text { FY } 1995 \text { SSPP } \\
\text { Rev. \# } 0 \\
26-\text { Sep-94 }\end{array}$} & Funding Source: \\
\hline & & & & & $G \& A \quad X X$ \\
\hline & & & & & \begin{tabular}{|l|} 
SWS \\
\end{tabular} \\
\hline & & & & & \begin{tabular}{|l} 
OST \\
\end{tabular} \\
\hline & & & & & DOH \\
\hline & & & & & MGT PRO \\
\hline \multirow{2}{*}{$\begin{array}{r}\text { Cost Account } \\
\text { 1MDD3X }\end{array}$} & \multirow{2}{*}{\multicolumn{3}{|c|}{$\begin{array}{l}\text { Cost Account Title } \\
\text { SAFEGUARDS AND SECURITY - G\&A }\end{array}$}} & & POOL \\
\hline & & & & & DIRECT \\
\hline $\begin{array}{l}\text { SMS WBS } \\
6.6 .2\end{array}$ & \multicolumn{3}{|c|}{$\begin{array}{l}\text { SMS Title } \\
\text { SAFEGUARDS AND SECURITY }\end{array}$} & \multirow{2}{*}{\multicolumn{2}{|c|}{$\begin{array}{c}\text { Annualized Rate } \\
\text { (For Organizational Overhead and } \\
\text { Rated Service Pool Use Only) } \\
\end{array}$}} \\
\hline \multicolumn{2}{|l|}{ CAM Review/Approval C.W. WALTON } & \multirow{2}{*}{\multicolumn{2}{|c|}{$\begin{array}{l}\text { Date } \\
\text { Date }\end{array}$}} & & \\
\hline \multicolumn{2}{|c|}{ SMS Program Manager Review/Approval $\quad$ C.W. WALTON } & & & FY 1994 Rate & FY 1995 Rate Request \\
\hline \multicolumn{2}{|c|}{ Financial Manager Review/Approval $\quad$ L.C. BAANDT } & \multicolumn{2}{|r|}{ Date } & & \\
\hline \multicolumn{2}{|l|}{ Responsible Analyst L.V.JONES } & \multicolumn{2}{|r|}{ Date } & FY 1995 Target Rate & FY 1995 Approved Rate \\
\hline \multicolumn{2}{|l|}{ OSBRB Review/Approval B.R. THOMAS } & \multicolumn{2}{|r|}{ Date } & & \\
\hline$\therefore \ldots, \cdots, \cdots, \cdots, \cdots \infty \%$ & FY19 & & & FY 1995 & 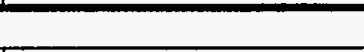 \\
\hline FULL-TIME EQUIVALENTS (FTES) & Budget & $\begin{array}{c}\text { Fiscal Year Spending } \\
\text { Forecast (FYSF) }\end{array}$ & Target & Request & $\begin{array}{l}\text { Approved } \\
\text { Baseline }\end{array}$ \\
\hline . Organizational - Exempt & & & (1/, & 24.1 & (1., \\
\hline . Organizational - Nonexempt & & & 1\%: & 12.3 & \\
\hline Organizational - Bargaining & & & (1. & & 8 \\
\hline Total Organizational FTEs & & & & 36.4 & \\
\hline Support FTEs & & & : & 1.0 & (1) \\
\hline TOTALFTES & 47.9 & 44.1 & - & 37.4 & \\
\hline - & $\frac{1}{2}$ & (1) & 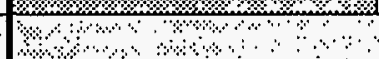 & 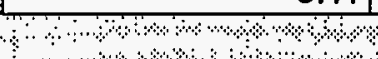 & ए। \\
\hline COST ELEMENTS & 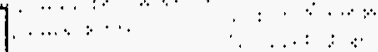 & & \%ल+ & ब्मा & ০০০ \%০০ \\
\hline . Labor - Regular & & & ২০। & 2,044 & া' \\
\hline . Labor - Overtime & & & (1., & 6 & \\
\hline 0 Total Labor & 2,395 & $\overline{0}$ & 3 & 2,050 & \\
\hline 1 Materials & 76 & & 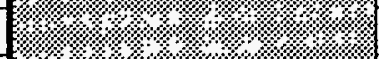 & 40 & 14 \\
\hline 2 Purchased Services & 407 & & \% & 71 & \% \\
\hline 3 Other Hanford & 16 & & \% & 66 & \\
\hline 4 Site Services & 375 & & (:) & 25 & \\
\hline 5 Internal Charges & 0 & & 19 & 0 & \\
\hline 6 IRM Support & 165 & & (2) & 578 & 19 \\
\hline 7 Overheads & 49 & & (4) & 873 & \\
\hline G\&A / SWS & 0 & & & & 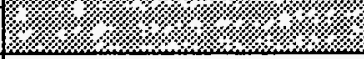 \\
\hline TOTALDOLLARS & 3,483 & 2,878 & & 3.703 & \\
\hline
\end{tabular}




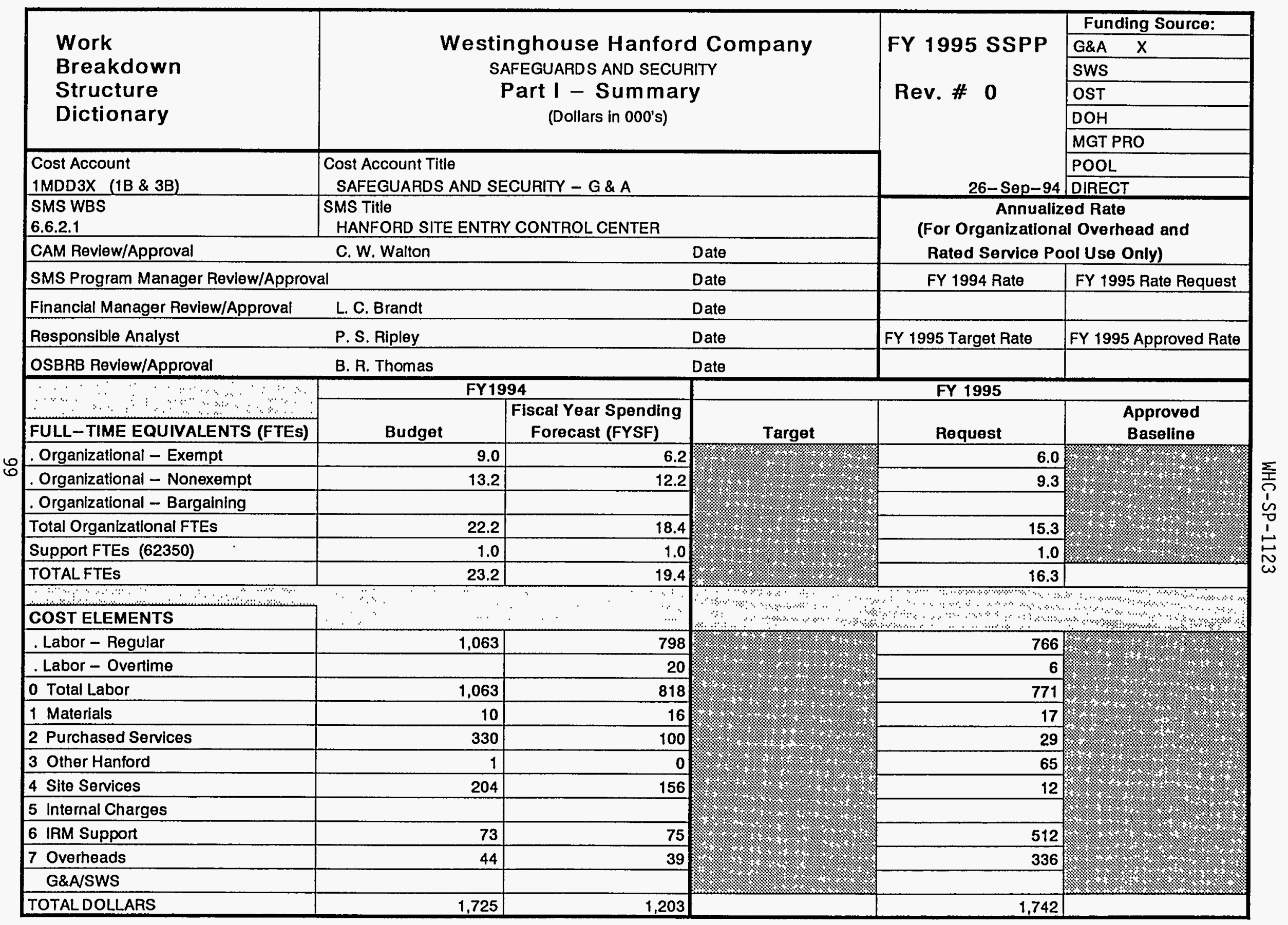




\begin{tabular}{|l|c|c|}
\hline $\begin{array}{l}\text { IMDD3X }(1 \mathrm{~B}, 2 \mathrm{~B}, 3 \mathrm{~B}) \\
\text { COST ACCOUNT }\end{array}$ & Westinghouse Hanford Company & FY95 SSSP \\
\hline $\begin{array}{l}\text { Work Breakdown } \\
\text { Structure }\end{array}$ & Safeguards and Security \\
Dictionary & Part II - Element Definition & Revision \#0 \\
\hline
\end{tabular}

\begin{tabular}{|l|l|}
\hline WBS ELEMENT CODE: 6.6 .2 .1 & TITLE: Access Control \\
\hline ELEMENT TASK DESCRIPTION \\
COST CONTENT - \\
G \& A \\
TECHNICAL CONTENT- \\
DOE $5631.2 C$ Personnel Security Program \\
OBJECTIVES - \\
Process and maintain security clearances and speciat accesses \\
Administer and maintain the Site's Access Control data base (Personnel Security Clearance Record [PSCR]) \\
ASSUMPTIONS/CONSTRAINTS- \\
Clearance processing activities will begin to be consolidated during FY95 \\
Staffing levels will decrease as work is reduced or transferred out of SAS \\
MILESTONES - \\
Complete development and installation of the PSCR+ system by February 1995 \\
DELIVERABLES - \\
Excellent service for customers requesting or requiring security clearances and special access. \\
\hline
\end{tabular}




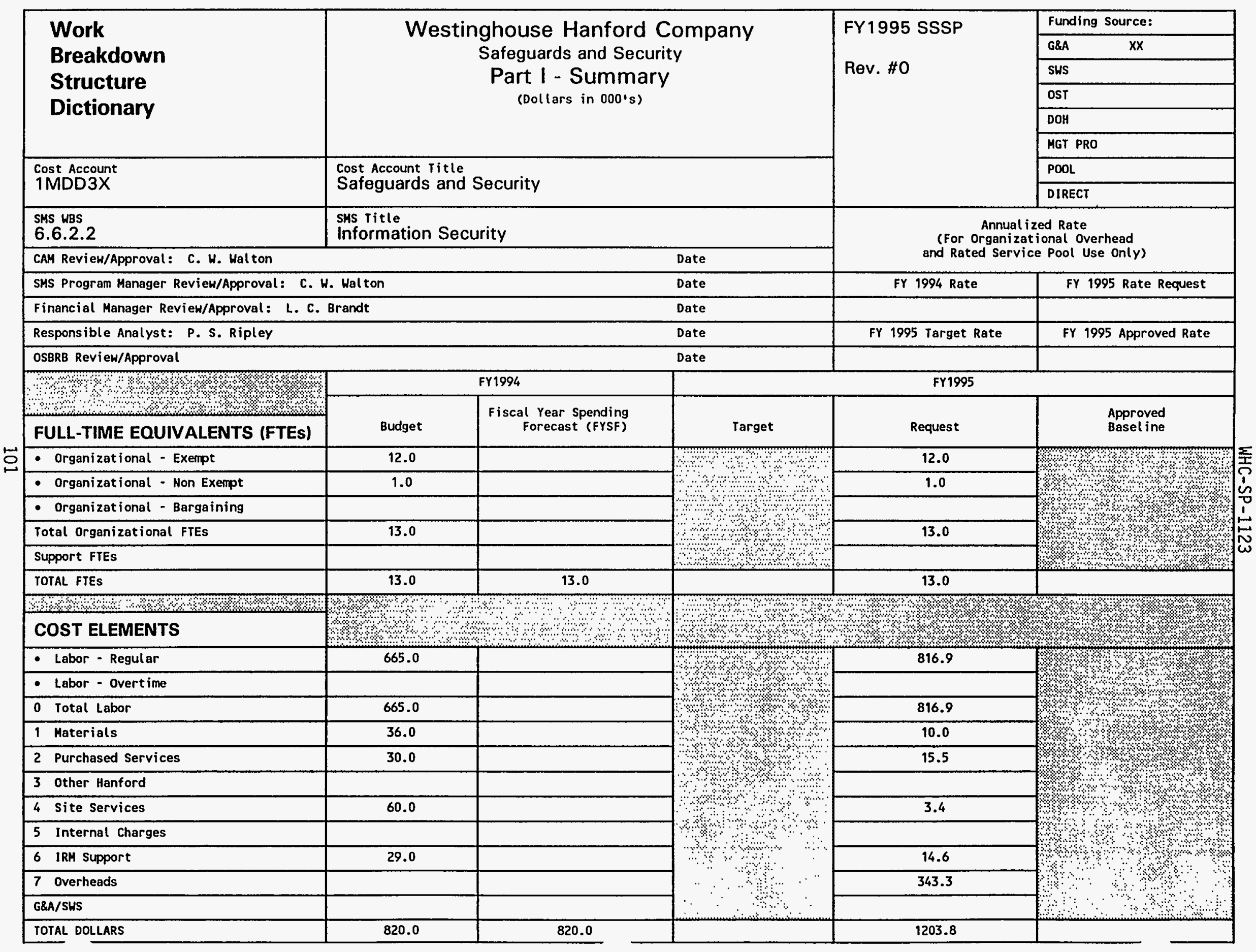




\begin{tabular}{|c|c|c|}
\hline $\begin{array}{c}\text { 1MDD3X } \\
\text { COST ACCOUNT }\end{array}$ & & - \\
\hline $\begin{array}{l}\text { Work Breakdown } \\
\text { Structure } \\
\text { Dictionary }\end{array}$ & $\begin{array}{c}\text { Westinghouse Hanford Company } \\
\text { Safeguards and Security } \\
\text { Part II - Element Definition }\end{array}$ & $\begin{array}{c}\text { FY } 1995 \text { SSSP } \\
\text { Revision \#0 }\end{array}$ \\
\hline
\end{tabular}

\begin{tabular}{|l|l|}
\hline WBS ELEMENT CODE: 6.6 .2 .2 & TITLE: Information Security \\
\hline ELEMENT TASK DESCRIPTION & \\
COST CONTENT - G\&A \\
TECHNICAL CONTENT -
\end{tabular}

\section{TECHNICAL CONTENT .}

Unclassified Computer Security: Oversee the operation of more than 17,000 computers, many of which are used to process sensitive and mission essential applications, to prevent unauthorized access to, or alteration of WHC hardware, software and data.

Classified Computer Security: Administer a program that can assure classified information is processed only on computers that have been formally approved and accredited for this purpose.

Counterintelligence: This program is designed to deter and neutralize foreign industrial or intelligence activities in the United States directed at or involving DOE programs, facilities, technology, personnel, unclassified sensitive information, and classified matter.

Operations Security: This program identifies information and processes that can be considered to be targets of interest by foreign intelligence interests. This program is structured to assure that information generated in support of mission areas is made available to the public through authorized release channels.

Classification: Provides classification and declassification support to all WHC organizations involved with classified or potentially classified subject areas. Oversees the conduct of the planned large-scale declassification review in support of the Secretary's Openness Initiative.

General: Oversees the conduct of telecommunications security, classified work for others (non-DOE funded) and Technical surveiliance Countermeasures. These programs are all designed to protect classified and sensitive unclassified information from unauthorized access.

OBJECTIVES - Unclassified Computer Security: Assure WHC compliance with DOE Orders governing unclassified computer processing. Assure that remote access to WHC and RL data bases by Tri-Party Agreement and other agencies does not jeopardize the integrity of Hanford networks and computer systems. Improve the process for the early identification and subsequent certification of sensitive applications. 


\begin{tabular}{|l|c|c|}
\hline \multicolumn{1}{|c|}{\begin{tabular}{|} 
1MDD3X \\
COST ACCOUNT
\end{tabular}} & FY 1995 SSSP \\
\hline $\begin{array}{l}\text { Work Breakdown } \\
\text { Structure } \\
\text { Dictionary }\end{array}$ & Westinghouse Hanford Company & Revision \#0 \\
\hline
\end{tabular}

\begin{tabular}{|l|l|}
\hline WBS ELEMENT CODE: $\mathbf{6 . 6 . 2 . 2}$ & TITLE: Information Security \\
\hline
\end{tabular}

\section{ELEMENT TASK DESCRIPTION}

OBJECTIVES (cont'd) - Classified Computer Security: Assure WHC compliance with DOE Orders governing classified computers and telecommunications. Assure that all classified computers are operated in accordance with approved ADP Security plans. Continue to reduce the number of classified computers used in WHC.

Counterintelligence: Assure WHC compliance with DOE Orders governing counterintelligence and foreign travel. Assure that all personnel traveling to sensitive foreign countries are given CI briefings prior to and upon completion of trave1. Assure CI briefings are given to Hosts and Escorts of sensitive country visitors to WHC. Assure CI briefings are given to Hosts and Escorts for non-sensitive country visitors when sensitive subjects are to be discussed. Assure CI Reports are completed for these activities.

Operations Security: Assure WHC compliance with DOE Orders governing Operations Security. Assure that WHC organizations establish the necessary Working Groups or Awareness Groups to fulfill the program requirements. Develop a concept of operations for "Risk Management" to reflect a migration from the traditional OPSEC approach for information protection.

Classification: Assure WHC compliance with DOE Orders governing classification and declassification. Improve the WHC declassification review process. Assure that personnel with adequate technical capabilities are available to support the newly authorized large-scale declassification review of Hanford historical classified documents.

ASSUMPTIONS/CONSTRAINTS - Unclassified Computer Security: The requirement to provide computer and telecommunication support to both non-DOE and non-WHC entities will continue to increase. The site's computer security environment will be subjected to increasing demands placed by other entities requiring remote access to Hanford systems and data bases. These demands will require increased coordination and training and will have to be met with no increase in staff.

Classified Computer Security: This program will continue to be used to support both WHC and RL classified processing requirements. Telecommunications Security (COMSEC, TEMPEST, and Protected Distribution Systems) will be conducted as part of the UHC Classified Computer Security Program. Staffing for this program will not be increased.

Counterintelligence: This newest Information Security program will continue to grow in FY95. Travel to foreign countries requiring special CI pre and post travel briefings will increase to require more than double the number of briefings conducted in FY 94 . Special visits by foreigners form sensitive countries and from non-sensitive countries involving sensitive subjects will continue to increase, requiring CI briefings prior to and following the visits. This increased workload will be absorbed by existing staff. 


\begin{tabular}{|c|c|c|}
\hline $\begin{array}{c}\text { 1MDD3X } \\
\text { COST ACCOUNT }\end{array}$ & & \\
\hline $\begin{array}{l}\text { Work Breakdown } \\
\text { Structure } \\
\text { Dictionary }\end{array}$ & $\begin{array}{c}\text { Westinghouse Hanford Company } \\
\text { Safeguards and Security } \\
\text { Part II - Element Definition }\end{array}$ & $\begin{array}{l}\text { FY } 1995 \text { SSSP } \\
\text { Revision \#0 }\end{array}$ \\
\hline
\end{tabular}

\begin{tabular}{|l|l|}
\hline WBS ELEMENT CODE: 6.6 .2 .2 & TITLE: Information Security \\
\hline ELEMENT TASK DESCRIPTION \\
$\cdot$ \\
ASSUMPTIONS/CONSTRAINTS (cont'd) -
\end{tabular}

Operations Security: The need to continually evaluate and assess operations in WHC facilities will increase as the number of foreign visits and assignments increase. Special consideration will have to be given to controlling computer access by foreign nationals supporting both WHC and RL contract efforts. Implementing cost-effective OPSEC countermeasures will become increasingly important as access to the Hanford site continues to be less restrictive.

Classification: The Classification Office will continue to identify and train technically qualified Authorized Classifiers and Declassifiers. Major emphasis will be placed on identifying personnel qual ified to support the recently authorized large-scale declassification review required by the Secretary's openness initiative. Permanent staff increases will not be authorized for the Classification office.

\section{MILESTONES -}

Unclassified Computer Security:

A11 (approximately 300) sensitive applications will be reviewed and certified by the WHC Computer Protection Program Manager in FY 95 . (4QFY 95)

A new Computer Security Awareness and Training program will be implemented for use on the Hanford Local Area Network. (2QFY94)

Update the WHC Computer Protection PIan required by DOE Order 1360.2B (3QFY95)

Classified Computer Security:

An updated training package will be implemented for users of classified computers (3QFY95)

Unannounced file content reviews of all WHC classified computers will be conducted (4QFY95).

Operations Security:

WHC FY94 OPSEC PIan - submitted to RL $4 Q \mathrm{fY} 95$. 


\begin{tabular}{|c|c|c|}
\hline $\begin{array}{c}1 \text { MDD3X } \\
\text { COST ACCOUNT }\end{array}$ & & \\
\hline $\begin{array}{l}\text { Work Breakdown } \\
\text { Structure } \\
\text { Dictionary }\end{array}$ & $\begin{array}{c}\text { Westinghouse Hanford Company } \\
\text { Safeguards and Security } \\
\text { Part II - Element Definition }\end{array}$ & $\begin{array}{l}\text { FY } 1995 \text { SSSP } \\
\text { Revision \#0 }\end{array}$ \\
\hline
\end{tabular}

\begin{tabular}{|c|c|}
\hline WBS ELEMENT CODE: 6.6 .2 .2 & TITLE: Information Security \\
\hline \multicolumn{2}{|l|}{ ELEMENT TASK DESCRIPTION } \\
\hline \multicolumn{2}{|l|}{ MILESTONES (cont'd) - } \\
\hline \multicolumn{2}{|c|}{$\begin{array}{l}\text { OPSEC Goals and Objectives - 1QFY95 (The goals and objectives each have their own milestone completion date spread } \\
\text { throughout the FY). }\end{array}$} \\
\hline \multicolumn{2}{|l|}{ Classification: } \\
\hline \multicolumn{2}{|c|}{ Identify the support staff necessary to conduct the WHC portion of the large scale declassification review. (1QFY95) } \\
\hline \multicolumn{2}{|c|}{ DELIVERABLES - } \\
\hline \multicolumn{2}{|c|}{ Unclassified Computer Security: } \\
\hline \multicolumn{2}{|c|}{ Provide updated WHC Computer Protection Plan to RL review - (June 30, 1995). } \\
\hline \multicolumn{2}{|c|}{ Status of unannounced random file content review to RL - Quarterly. } \\
\hline \multicolumn{2}{|c|}{$\begin{array}{l}\text { Provide RL with a copy of the questions used in the new computer security awareness and training program. } \\
\text { (Sept. } 30,1994 \text { ) }\end{array}$} \\
\hline \multicolumn{2}{|c|}{ Report on the results of the certification process for all WHC sensitive applications and essential systems. } \\
\hline \multicolumn{2}{|c|}{ Unclassified Computer Security Incident Reports - on occurrence. } \\
\hline \multicolumn{2}{|c|}{$\begin{array}{l}\text { Provide RL with a copy of the questions used in the updated classified computer security training package. (June } 30 \text {, } \\
\text { 1995) }\end{array}$} \\
\hline \multicolumn{2}{|c|}{ Provide RL with a report of the results file content reviews (Sept. 30,1995 ) } \\
\hline $\begin{array}{l}\text { Quarterly report on the } \\
\text { workstations. }\end{array}$ & at address security concerns on WHC computers and \\
\hline
\end{tabular}




\begin{tabular}{|l|c|c|}
\hline \multicolumn{1}{|c|}{\begin{tabular}{|c|} 
1MDD3X \\
COST ACCOUNT
\end{tabular}} & Westinghouse Hanford Company & FY 1995 SSSP \\
\hline $\begin{array}{l}\text { Work Breakdown } \\
\text { Structure } \\
\text { Dictionary }\end{array}$ & Safeguards and Security & Revision \#0 \\
\hline
\end{tabular}

\begin{tabular}{|c|c|}
\hline WBS ELEMENT CODE: 6.6 .2 .2 & TITLE: Information Security \\
\hline \multicolumn{2}{|l|}{$\begin{array}{l}\text { ELEMENT TASK DESCRIPTION } \\
\text { DELIVERABLES - (continued) }\end{array}$} \\
\hline \multicolumn{2}{|c|}{ Classified Computer Security: } \\
\hline \multicolumn{2}{|c|}{$\begin{array}{l}\text { Provide RL with a copy of the questions and the supporting training aids used in the updated classified computer } \\
\text { security training package. (June } 30,1995 \text { ) }\end{array}$} \\
\hline \multicolumn{2}{|c|}{ Provide RL with a report of the results file content reviews. (Sept. 30,1995 ) } \\
\hline \multicolumn{2}{|c|}{ Submit new or significantly changed ADP security plans for classified computers to RL for review. (On-going) } \\
\hline \multicolumn{2}{|c|}{$\begin{array}{l}\text { Counterintelligence: } \\
\text { CI Contact/Incident Reports to RL of which WHC employee travel to foreign countries (80-100) - on going }\end{array}$} \\
\hline \multicolumn{2}{|c|}{$\begin{array}{l}\text { CI Contact/Incident Reports to RL of host/escorts of foreign visitors from sensitive countries }(100-120)-\text { on going } \\
\text { CI Administration Inquiries in response to RL or RL/FBI requests - as requested }\end{array}$} \\
\hline \multicolumn{2}{|c|}{$\begin{array}{l}\text { Operations Security: } \\
\text { Maintain listings of sensitive and security facilities for RL - quarterly }\end{array}$} \\
\hline \multicolumn{2}{|c|}{$\begin{array}{l}\text { Review foreign visit/assignment specific security plans for OPSEC interests and program approval prior to wHC submitted } \\
\text { to RL - on going }\end{array}$} \\
\hline \multicolumn{2}{|c|}{ Submit WHC FY95 OPSEC Plan to RL - October 1, 1994} \\
\hline \multicolumn{2}{|c|}{$\begin{array}{l}\text { Submit WHC Critical Sensitive Information List and Essential and Essential Elements of Friendly Information List to RL - } \\
\text { January } 1,1994\end{array}$} \\
\hline $\begin{array}{l}\text { Submit minutes of WHC } 0 \& E \\
\text { Submit results of OPSEC A }\end{array}$ & RL - quarterly \\
\hline
\end{tabular}




\begin{tabular}{|l|c|c|}
\hline \multicolumn{1}{|c|}{\begin{tabular}{|c}
\multicolumn{2}{|c|}{$1 \mathrm{MDD} 3 \mathrm{X}$} \\
COST ACCOUNT
\end{tabular}} & Westinghouse Hanford Company & FY 1995 SSSP \\
\hline $\begin{array}{l}\text { Work Breakdown } \\
\text { Structure } \\
\text { Dictionary }\end{array}$ & Part II - Elements Definition & Revision \#0 \\
\hline
\end{tabular}

\begin{tabular}{|l|l|}
\hline WBS ELEMENT CODE: 6.6 .2 .2 & TITLE: Information Security \\
\hline ELEMENT TASK DESCRIPTION & DELIVERABLES - (continued) \\
Classification: \\
Provide classification/declassification support to WHC and RL as requested - on going \\
Conduct Authorized Derivative Classifier training for WHC authorized classifiers - on going \\
Provide support to RL for Headquarters Classification office Appraisal - on request \\
Initiate the WHC portion of the RL large scale declassification review - 1QFY95 \\
\end{tabular}




\begin{tabular}{|c|c|c|c|c|c|}
\hline \multirow{6}{*}{$\begin{array}{l}\text { Work } \\
\text { Breakdown } \\
\text { Structure } \\
\text { Dictionary }\end{array}$} & \multirow{6}{*}{\multicolumn{3}{|c|}{$\begin{array}{c}\text { Westinghouse Hanford Company } \\
\text { Safeguards and Security } \\
\text { Part I - Summary } \\
\text { (Dollars in } 000^{\prime} \text { ) }\end{array}$}} & \multirow{8}{*}{$\begin{array}{r}\text { FY } 1995 \text { SSPP } \\
\text { Rev. \# } 0 \\
26-\text { Sep-94 }\end{array}$} & Funding Source: \\
\hline & & & & & \begin{tabular}{|l|} 
G\&A \\
CWIC
\end{tabular} \\
\hline & & & & & sWS \\
\hline & & & & & OST \\
\hline & & & & & \multirow{2}{*}{\begin{tabular}{|l|} 
DOH \\
MGT PRO \\
\end{tabular}} \\
\hline & & & & & \\
\hline Cost Account & Cost Account Title & \multirow{2}{*}{\multicolumn{2}{|c|}{ Safequards and Security }} & & POOL \\
\hline $1 M D D 3 X$ & & & & & \begin{tabular}{|l} 
DIRECT \\
\end{tabular} \\
\hline 6.6 .2 .3 & SMS Title & \multicolumn{2}{|l|}{ Security Investigations } & \multirow{2}{*}{\multicolumn{2}{|c|}{\begin{tabular}{|c|} 
Annualized Rate \\
$\begin{array}{c}\text { (For Organizational Overhead and } \\
\text { Rated Service Pool Use Only) }\end{array}$ \\
\end{tabular}}} \\
\hline \multicolumn{2}{|l|}{ CAM Review/Approval C.W. WALTON } & \multicolumn{2}{|r|}{ Date } & & \\
\hline \multicolumn{2}{|c|}{ SMS Program Manager Review/Approval $\quad$ C.W. WALTON } & \multicolumn{2}{|r|}{ Date } & FY 1994 Rate & FY 1995 Rate Request \\
\hline \multicolumn{2}{|c|}{ Financial Manager Review/Approval L.C. BRANDT } & \multicolumn{2}{|r|}{ Date } & & \multirow[b]{2}{*}{ FY 1995 Approved Rate } \\
\hline \multicolumn{2}{|l|}{ Responsible Analyst L.V. JONES } & \multicolumn{2}{|r|}{ Date } & FY 1995 Target Rate & \\
\hline \multicolumn{2}{|l|}{ OSBRB Revlew/Approval } & \multicolumn{2}{|r|}{ Date } & & \multirow{2}{*}{ L } \\
\hline \multirow{2}{*}{ 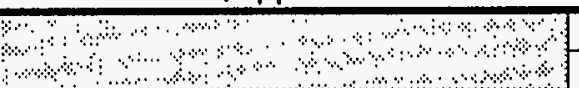 } & \multicolumn{2}{|c|}{ FY1994 } & & FY 1995 & \\
\hline & & $\begin{array}{c}\text { Fiscal Year Spending } \\
\text { Forecast (FYSF) }\end{array}$ & & Request & $\begin{array}{c}\text { Approved } \\
\text { Baseline }\end{array}$ \\
\hline FULL-TIME EQUIVALENTS (FTES) & Budget & & Target & & \\
\hline Organizational - Exempt & 6 & 6 & 1 & 3.1 & (1) \\
\hline . Organizational - Nonexempt & 1 & 1 & ।. & 0.5 & + \\
\hline . Organizational - Bargaining & & & & & 1. \\
\hline Total Organizational FTEs & 7 & 7 & : & 3.6 & (1) \\
\hline Support FTES & & & & & (1):- \\
\hline TOTALFTES & 7 & 7 & 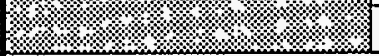 & 3.6 & \\
\hline U⿴囗十 $\quad$ in & a. & 28 & +० & अे ४ & ২ै ২ ২े \\
\hline COST ELEMENTS & & & 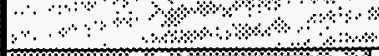 & 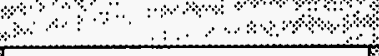 & 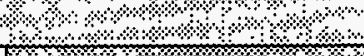 \\
\hline . Labor - Regular & 447 & 447 & $19.1 \%$ (1.।. & 217 & \\
\hline . Labor - Overtime & & & 1\%: & & 19: \\
\hline 0 Total Labor & 447 & 447 & (4).। & 217 & $(1818.2 .4$. \\
\hline 1 Materials & 13 & 13 & (4) & 8 & ; \\
\hline 2 Purchased Services & (28) & (28) & (4. & 15 & 18 \\
\hline 3 Other Hanford & 0 & 0 & (1\% & 0 & $1 \%$ \\
\hline 4 Site Services & 46 & 46 & \% & 6 & \% \\
\hline 5 Internal Charges & 0 & 0 & \%। & 0 & \\
\hline 6 IRM Support & 23 & 23 & & 13 & \\
\hline 7 Overheads & & & 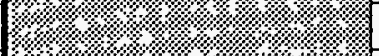 & 91 & \\
\hline 7 G\&AVSWS & & & 18 (1) & & 1.:\% \\
\hline TOTAL DOLLARS & 501 & 501 & & 350 & \\
\hline
\end{tabular}




\begin{tabular}{|l|c|c|}
\hline \multicolumn{1}{|c|}{\begin{tabular}{|c|}
$|c|$ \\
COST ACCOUNT
\end{tabular}} & FY 1995 SSPP \\
\hline $\begin{array}{l}\text { Work Breakdown } \\
\text { Structure } \\
\text { Dictionary }\end{array}$ & Westinghouse Hanford Company \\
\end{tabular}

\begin{tabular}{|c|c|c|c|}
\hline WBS ELEMENT COOE: & 6.6.2.3 & TITLE: & Security Investigations \\
\hline
\end{tabular}

ELEMENT TASKDESCRIPTION

\section{COST CONTENT -}

This element is G\&A funded.

\section{TECHNICAL CONTENT -}

The element is responsible for planning, executing and documenting formal, comprehensive, timely and objective investigations into incidents of a security concern as mandated by DOE Order and other applicable directives, and at the request of WHC senior management and RL. Regulatory drivers that impact the element are DOE 5632.1C, "Protection and Control of Safeguards and Security Interests", DOE5639.3, Violation of Laws, Losses, and incidents of Security Concerns", RLID 5632.PA, "Prohibited Articles Policy", and RL 5635.2, "Control of Classified Documents and Information".

The element will provide investigative services for security related incidents in a manner that meets the requirements of federal and state regulations, DOE Orders, safety and environmental compliance requirements, and other WHC company policies.

\section{ASSUMPTIONS/CONSTRAINTS -}

Security investigations will be conducted only for incidents defined as significant by RL and event tracking and analysis will be perfomed to identify significant events/trends.

\section{MILESTONES -}

The Security Analysis Office Workscope Realignment/Reduction Plan, as approved by RL on 8/15/94, will be fully implemented by 3/1/95.

\section{DELIVERABLES -}

- Investigations of reported/alleged non-compliance to DOE/WHC security directives.

- Investigations of non-compliance to DOE mandates for the protection of classified information and sensitive/high-value property.

- Reports regarding alleged/suspected criminal waste/fraud/abuse, violations of law, or incidents of security concern requested by DOE-RL after deferral from DOE-IG or BCSO.

- Investigations by special request into internal/external matters of a security interest not specifically delineated within DOE order or company policy.

- Trending of significant security incidents having relevance to the security posture of the site.

- Analysis of Hanford Site occurrence reports to assess disposition of SAS interests. 


\begin{tabular}{|c|c|c|c|c|c|}
\hline \multirow{6}{*}{$\begin{array}{l}\text { Work } \\
\text { Breakdown } \\
\text { Structure } \\
\text { Dictionary }\end{array}$} & \multirow{6}{*}{\multicolumn{3}{|c|}{$\begin{array}{c}\text { Westinghouse Hanford Company } \\
\text { Safeguards and Security } \\
\text { Part I - Summary } \\
\text { (Dollars in } 000^{\prime} \text { s) }\end{array}$}} & \multirow{8}{*}{$\begin{array}{l}\text { FY1995 SSSP } \\
\text { Rev. \#0 }\end{array}$} & Funding Source: \\
\hline & & & & & G\&A $\quad X X$ \\
\hline & & & & & SWS \\
\hline & & & & & OST \\
\hline & & & & & DOH \\
\hline & & & & & MGT PRO \\
\hline \multirow{2}{*}{$\begin{array}{l}\text { Cost Account } \\
1 \mathrm{MDD} 3 X\end{array}$} & \multirow{2}{*}{\multicolumn{3}{|c|}{$\begin{array}{l}\text { Cost Account Title } \\
\text { Safeguards and Security }\end{array}$}} & & POOL \\
\hline & & & & & DIRECT \\
\hline $\begin{array}{l}\text { SMS WBS } \\
6.6 .2 .4\end{array}$ & \multicolumn{3}{|c|}{$\begin{array}{l}\text { SMS ritle } \\
\text { Security Education }\end{array}$} & \multirow{2}{*}{\multicolumn{2}{|c|}{$\begin{array}{l}\text { Annualized Rate } \\
\text { (For Organizational overhead } \\
\text { and Rated Service Pool Use Only) }\end{array}$}} \\
\hline \multicolumn{3}{|l|}{ CAM Review/Approval: C. W. Halton } & Date & & \\
\hline SMS Program Manager Review/Approval: $0 . J$ & . Haskins & & Date & FY 1994 Rate & FY 1995 Rate Request \\
\hline \multicolumn{3}{|c|}{ Financial Manager Review/Approval: L. C. Brandt } & Date & & \multirow[b]{2}{*}{ FY 1995 Approved Rate } \\
\hline Responsible Analyst: P. S. Ripley & & & Date & FY 1995 Target Rate & \\
\hline OSBRB Review/Approval & & & Date & & \\
\hline । ২ & \multicolumn{2}{|r|}{ FY1994 } & \multicolumn{3}{|c|}{ FY1995 } \\
\hline 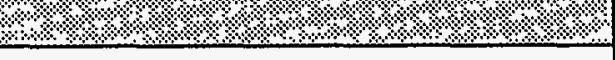 & & & & & \multirow{2}{*}{$\begin{array}{l}\text { Approved } \\
\text { Basel ine }\end{array}$} \\
\hline FULL-TIME EQUIVALENTS (FTES) & Budget & Forecast (FYSF) & Target & Request & \\
\hline - Organizational - Exempt & 3.0 & & \multirow{5}{*}{$\left(\begin{array}{l}1+1 \\
+ \\
+\end{array}\right.$} & 3.0 & \multirow{5}{*}{ 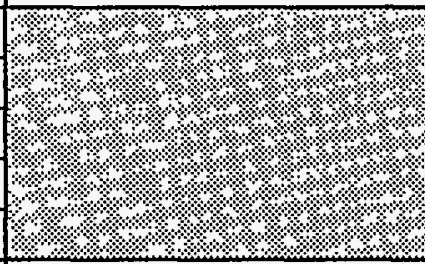 } \\
\hline - Organizational - Non Exempt & 1.7 & & & 1.5 & \\
\hline \multicolumn{4}{|l|}{ - Organizational - Bargaining } & & \\
\hline Total Organizational FTEs & 4.7 & & & 4.5 & \\
\hline Support FTES & & & & & \\
\hline TOTAL FTES & 4.7 & & & 4.5 & \\
\hline COST FI FMFNTS & $1 \%$ & ४ै. & $(1+)+.\%$ & (4.) & \% \\
\hline COST ELEMENTS & & & 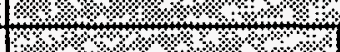 & $\frac{2.18}{244.3}$ & $14 .+2.4 .4 \%$ \\
\hline - Labor - Regular & 244.1 & & $1 \%$ (.) & 244.3 & 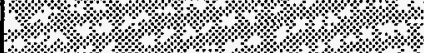 \\
\hline - Labor - Overtime & & & $\%$ & & ४ै। \\
\hline 0 Total Labor & 244.1 & & ২ ২ \% & 244.3 & ২ং. \\
\hline 1 Materials & 6.9 & & $1 \% .+2.4$. & 5.0 & 1. \\
\hline 2 Purchased Services & 15.0 & & (2. & 11.0 & ४ै \\
\hline 3 Other Hanford & & & $\%$ & 1.0 & \% \\
\hline 4 site Services & 55.0 & & ४ै. & 4.0 & \\
\hline 5 Internal Charges & & & e & & \%ै। \\
\hline 6 IRM Support & 33.0 & & $\%$ & 38.5 & ॥ \\
\hline 7 Overheads & & & ি। ২ ২ ০ & 102.6 & \\
\hline G\&A/SHS Adders & & & 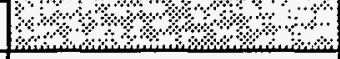 & & 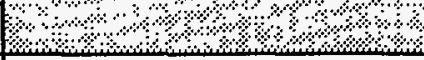 \\
\hline TOTAL DOLLARS & 354.0 & & & 406.4 & \\
\hline
\end{tabular}




\begin{tabular}{|c|c|c|}
\hline $\begin{array}{c}1 \text { MDD } 3 X \\
\text { COST ACCOUNT } \\
\end{array}$ & & \\
\hline $\begin{array}{l}\text { Work Breakdown } \\
\text { Structure } \\
\text { Dictionary }\end{array}$ & $\begin{array}{c}\text { Westinghouse Hanford Company } \\
\text { Safeguards and Security } \\
\text { Part II - Element Definition }\end{array}$ & $\begin{array}{l}\text { FY } 1995 \text { SSSP } \\
\text { Revision \#0 }\end{array}$ \\
\hline
\end{tabular}

\begin{tabular}{|l|l|}
\hline WBS ELEMENT CODE: 6.6 .2 .4 & TITLE: Security Education \\
\hline ELEMENT TASK DESCRIPTION &
\end{tabular}

COST CONTENT - Security Education - General and Administration (G\&A)

TECHNICAL CONTENT -

Primary Mission

- Develop and implement a standardize Security Education program for the Hanford Site.

Regulatory Drivers

Regulatory Drivers to support this funding source are as follows:

- DOE Order 5631.1c, "Safeguards and Security Awareness Program"

- RLID 5631.2A, "Safeguards and Security Awareness Program at the Richland Field office"

OBJECTIVES -

- Develop and implement a Security Education program that assures basic security awareness training of all employees, visitors/vendors, contractors, and foreign nationals.

- Assure compliance with all safety regulations.

- Provide support for implementation of DOE Order 5630.15, "SAS Training Program."

- Develop a Computer Based Training (CBT) module for the Comprehensive Security Briefing.

- Provide review and assure implementation of new orders, directives, and RLIDs.

ASSUMPTIONS/CONSTRAINTS -

- The Hanford General Employee Training (HGET) programs will be revised to reflect current security criteria.

- Provide assistance to RL SAS as requested.

MILESTONES -

- Ensure all cleared active WHC/BCSR/ICF KH employees attend the Security Refresher briefing in compliance with DOE Order 5631.1B, by March 31, 1995.

- Develop the 1995 Security Refresher briefing for presentation on the Hanford General Employee Training (HGET) program and submit to Advanced Training Technologies for implementation by January 1, 1995. 


\begin{tabular}{|l|c|c|}
\hline \multicolumn{1}{|c|}{\begin{tabular}{|c|}
\multicolumn{1}{c|}{ 1MDD3X } \\
COST ACCOUNT
\end{tabular}} & Westinghouse Hanford Company & FY 1995 SSSP \\
\hline $\begin{array}{l}\text { Work Breakdown } \\
\text { Structure } \\
\text { Dictionary }\end{array}$ & $\begin{array}{c}\text { Safeguards and Security } \\
\text { Revision \#0 }\end{array}$ \\
\hline
\end{tabular}

\begin{tabular}{|l|l}
\hline WBS ELEMENT CODE: 6.6 .2 .4 & TITLE: Security Education \\
\hline
\end{tabular}

ELEMENT TASK DESCRIPTION (cont'd)

\section{DELIVERABLES -}

- Review the current termination process for non-cleared employees and contractors and determine the most cost effective method, e.g., retain within Security Education or transfer responsibility to Human Resources and Procurement by December 1, 1994.

- Review security awareness program for business practice improvements by March 31, 1995.

In compliance with DOE Order 5631.1B and RLID 5631.2A the following briefings will be provided:

- Initial Security Briefing - Computer Based Training

- Comprehensive Security Briefing

- Security Refresher Briefing - Computer Based Training

- Visitor/Vendor Orientations - Video

- Contractor Termination Briefing

- Clearance Termination Briefing 


\section{ELEMENT TASKDESCRIPTION}

\section{WORK STATEMENT -}

\section{Activity Detailed Description - ACCESS CONTROL}

Process and maintain security clearances and special accesses Authorize site access for WHC, ICF KH.

Administer and maintain the Site's Access Control data base.

\section{Activity Detalled Description - INFORMATION SECURITY}

Labor Cost

Assure WHC compliance with DOE Orders governing unclassified computer processing, classified computers and tele-

communications, counterintelligence and foreign travel, Operations Security, and classification and declassification.

Activity Detailed Description - SECURITY INVESTIGATIONS Labor Cost Provide investigative services for security related incidents in a manner that meets the requirements of federal and state regulations, DOE Orders, safety and environmental compliance requirements, and other WHC company policies.

Labor Cost Non-Labor Cost

\section{Activity Detailed Description - SECURITY EDUCATION}

Develop and implement a Security Education Program that assures security awareness training of all employees, visitors/vendors, contractors, and foreign nationals. Provide support for implementation of DOE Order 5630.15, "SAS Training Program." Develop a computer based training module for the Comprehensive Security Briefing.

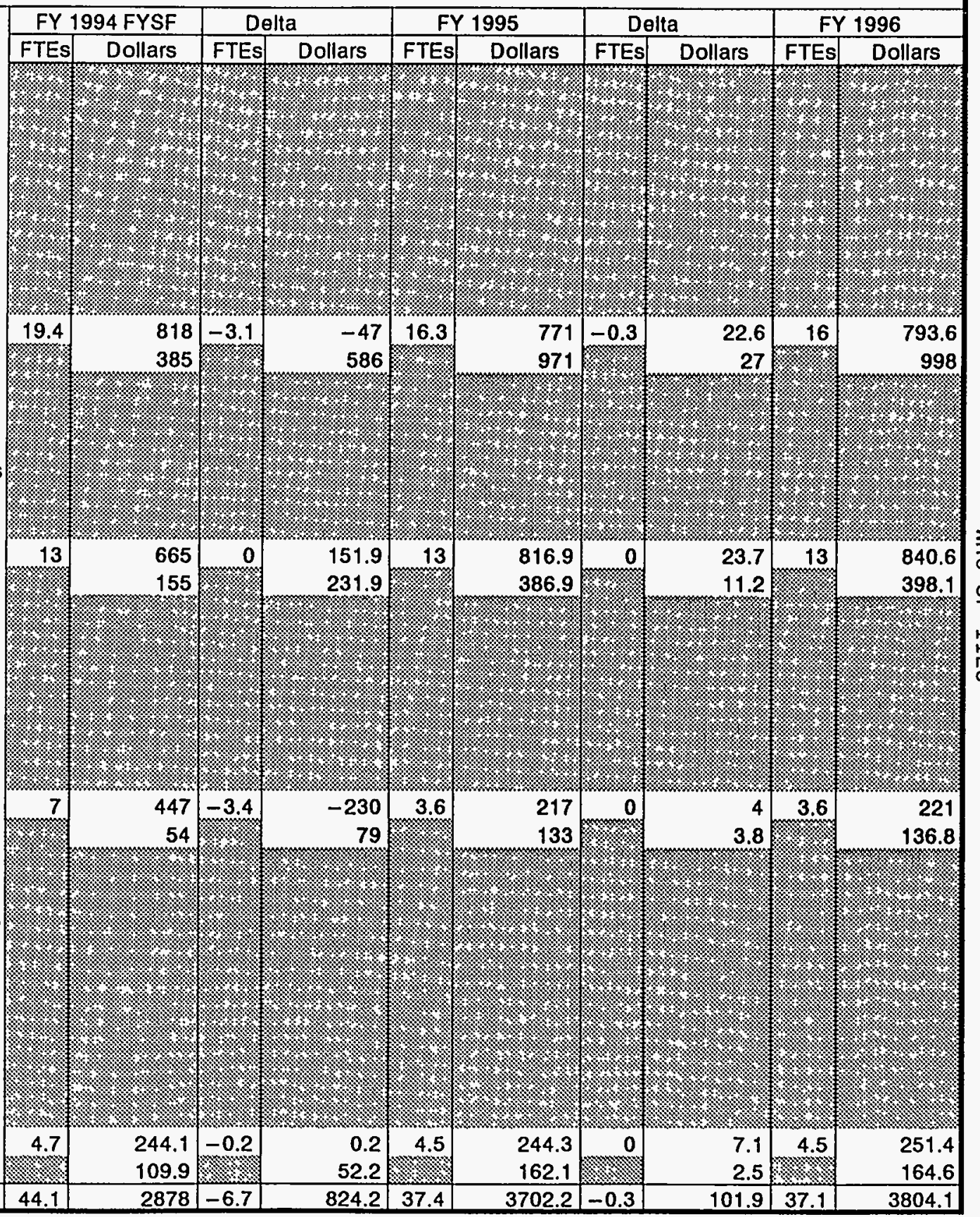




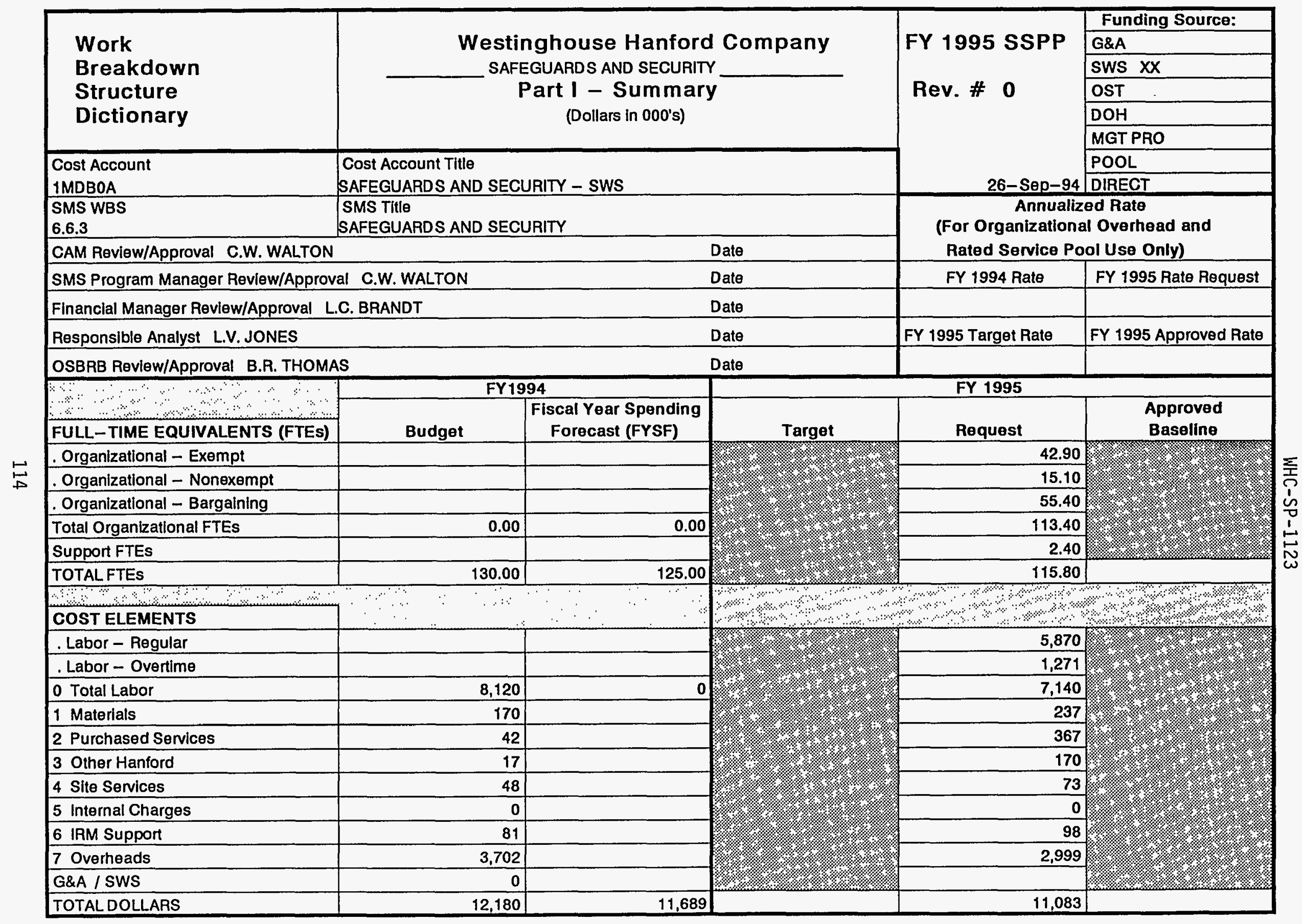




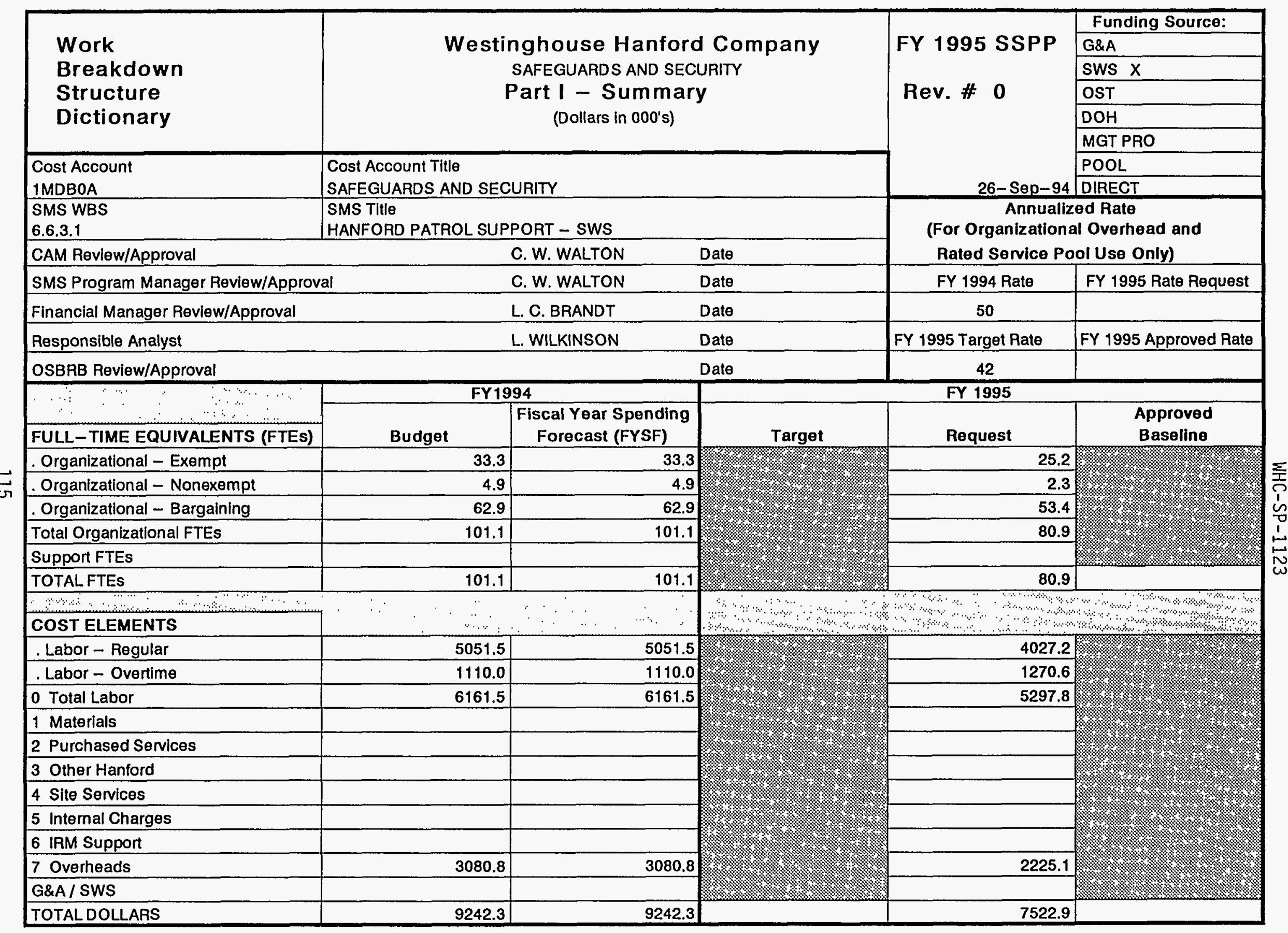


IMDBOA

COST ACCOUNT

Work Breakdown

Structure

Dictionary

Westinghouse Hanford Company Safeguards and Security

Part II - Element Definition
FY 1995 SSPP

Revision \#0

\begin{tabular}{|c|c|c|}
\hline WBS ELEMENT CODE & 6.6 .3 .1 & TITLE: HANFORD PATROL \\
\hline
\end{tabular}

ELEMENT TASK DESCRIPTION

COST CONTENT -

This activity is funded by the Site Wide Support Pool (SWS).

\section{TECHNICAL CONTENT -}

Provide a professional protective force that is highly trained and effective in techniques for physical protection, emergency response, and public service. The Hanford Site is supported on a 24-hour basis by 4 site rovers, 2 site barricades, and the SRT. The SWS is also allocated a portion of the Shift Commander, Shift Lieutenants, PTA, and POC support.

DOE Order 5632.7 - Protective Forces

DOE Order 5631.1A - Protection Program Operation

DOE Order 5632.1C - Protection and Control of Safeguards and Security Interests

\section{OBJECTIVES -}

Physically protect Special Nuclear Material, classified information, U.S. Government property, and personnel as a service to SWS.

\section{ASSUMPTIONS/CONSTRAINTS -}

The Patrol force will continue to be responsible to respond to and control any incident that threatens 1 ife or property on the Site until relieved by other authority.

\section{MILESTONES -}

DELIVERABLES - 


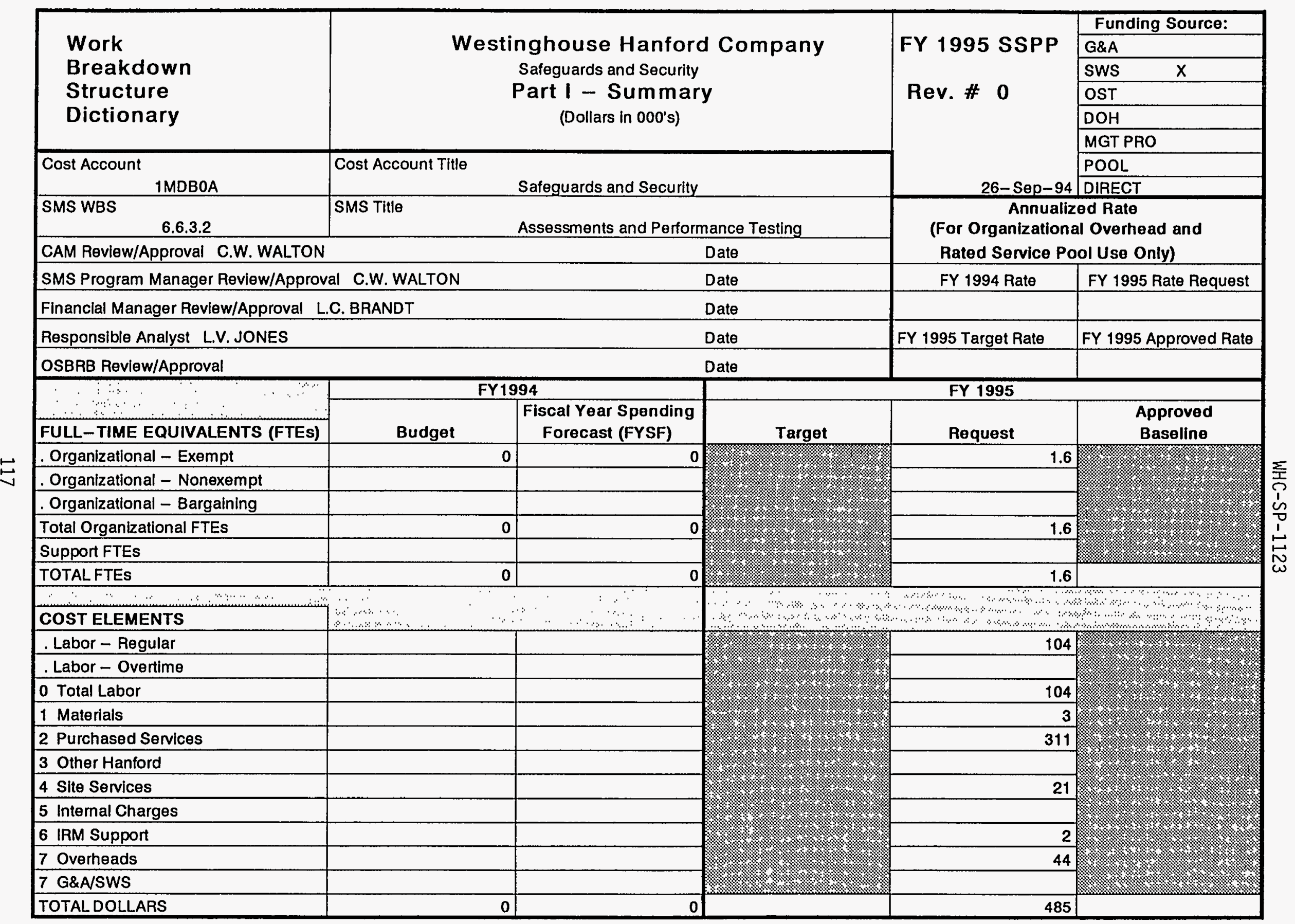




\begin{tabular}{|l|c|c|}
\hline \multicolumn{1}{|c|}{ 1MDBOA } & & \\
\hline COST ACCOUNT & Westinghouse Hanford Company & FY 1995 SSPP \\
Work Breakdown & Safeguards and Security & Revision \# 0 \\
Dictionary & Part II - Element Definition & Rre \\
\hline
\end{tabular}

\begin{tabular}{|c|c|}
\hline WBS ELEMENT CODE: & Assessments and Performance Testing \\
\hline
\end{tabular}

COST CONTENT -

This element is funded by Site Wide Support.

\section{TECHNICAL CONTENT -}

This element is responsible for developing, maintaining, and implementing policies and procedures governing internal surveys and testing of Safeguards and Security systems in conformance with DOE orders. The regulatory drivers that impact the element are DOE 5630.16A, DOE 5633.3A and DOE 5634.1B.

\section{OBJECTIVES -}

The element will test Safeguards and Security systems in a manner that meets the requirements of federal and state regulations, DOE Orders, safety and environmental compliance requirements, and other WHC company policies. In addition, the element will proactively identify SAS Issues, develop workable solutions, and follow through on implementation of solutions.

\section{ASSUMPTIONS/CONSTRAINTS -}

SAS will implement a program to outsource internal surveys of SAS major program elements.

\section{MILESTONES -}

Outsource WHC SAS internal survey program by February 28, 1995.

Study and document proposal for outsourcing MBA audits by December 15, 1994.

Full implementation of DOE Order 5630.16A requirements by August 25, 1995. (Stretch Goal - June 30,1995)

Complete all internal surveys required by DOE 5634.1B and/or an alternative set of internal surveys approved by RL by August 31, 1995. (Stretch Goal -

June 30, 1995)

\section{DELIVERABLES -}

- Safeguards and Security topical area internal surveys required by DOE Order 5634.18 .

- Material balance area internal surveys

- Performance tests as required by DOE 5630.16A.

- Participation in site-wide exercises which include testing of Safeguards and Security systems

- Validation of corrective actions to internal and RL survey findings. 


\begin{tabular}{|c|c|c|c|c|c|}
\hline \multirow{6}{*}{$\begin{array}{l}\text { Work } \\
\text { Breakdown } \\
\text { Structure } \\
\text { Dictionary }\end{array}$} & \multirow{6}{*}{\multicolumn{3}{|c|}{$\begin{array}{c}\text { Westinghouse Hanford Company } \\
\text { Safeguards and Security } \\
\text { Part I - Summary } \\
\text { (Dollars in 000's) }\end{array}$}} & \multirow{8}{*}{$\begin{array}{l}\text { FY1995 SSSP } \\
\text { Rev. \#0 }\end{array}$} & Funding Source: \\
\hline & & & & & G\&A \\
\hline & & & & & SHS \\
\hline & & & & & OST \\
\hline & & & & & DOH \\
\hline & & & & & MGT PRO \\
\hline \multirow{2}{*}{$\begin{array}{l}\text { Cost Account } \\
1 \mathrm{MDBOA}\end{array}$} & \multirow{2}{*}{\multicolumn{3}{|c|}{\begin{tabular}{|l|} 
Cost Account ritle \\
Safeguards and Security
\end{tabular}}} & & POOL \\
\hline & & & & & DIRECT \\
\hline $\begin{array}{l}\text { SMS WBS } \\
\text { 6.6.3.3.1 }\end{array}$ & \multicolumn{3}{|c|}{$\begin{array}{l}\text { SMS Title } \\
\text { Industrial Security South }\end{array}$} & \multirow{2}{*}{\multicolumn{2}{|c|}{$\begin{array}{c}\text { Annualized Rate } \\
\text { (For Organizational overhead } \\
\text { and Rated Service Pool Use Only) }\end{array}$}} \\
\hline \multicolumn{3}{|l|}{ CAM Review/Approval: C. W. Walton } & Date & & \\
\hline \multicolumn{3}{|c|}{ SMS Program Manager Review/Approval: 0. R. Dovalle } & Date & FY 1994 Rate & FY 1995 Rate Request \\
\hline \multicolumn{3}{|c|}{ Financial Manager Review/Approval: $\quad$ L. C. Brandt } & Date & & \\
\hline \multicolumn{3}{|l|}{ Responsible Analyst: P. S. Ripley } & Date & FY 1995 Target Rate & FY 1995 Approved Rate \\
\hline \multicolumn{3}{|l|}{ OSBRB Review/Approval } & Date & & \\
\hline \multicolumn{3}{|l|}{ ४ } & \multicolumn{3}{|c|}{ FY1995 } \\
\hline ২ै. & \multirow[b]{2}{*}{ Budget } & \multirow{2}{*}{$\begin{array}{l}\text { Fiscal Year Spending } \\
\text { Forecast (FYSF) }\end{array}$} & \multirow[b]{2}{*}{ Target } & \multirow[b]{2}{*}{ Request } & \multirow{2}{*}{$\begin{array}{l}\text { Approved } \\
\text { Basel ine }\end{array}$} \\
\hline FULL-TIME EQUIVALENTS (FTES) & & & & & \\
\hline - Organizational - Exempt & 2.6 & 2.6 & \multirow{5}{*}{$\begin{array}{ll}+1 \\
+ \\
+\end{array}$} & 3.8 & \multirow{5}{*}{ 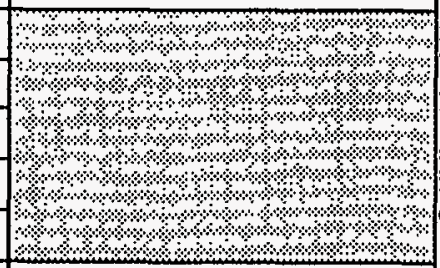 } \\
\hline - Organizational - Non Exempt & 1.5 & 1.5 & & 1.3 & \\
\hline - Organizational - Bargaining & 2.0 & 2.0 & & 2.0 & \\
\hline Total Organizational FTEs & 6.15 & 6.15 & & 72 & \\
\hline Support FTES (BCSR) & 0.25 & 0.25 & & & \\
\hline TOTAL FTES & 6.35 & 6,35 & & 7.1 & \\
\hline COST ELEMENTS & \multicolumn{4}{|c|}{ 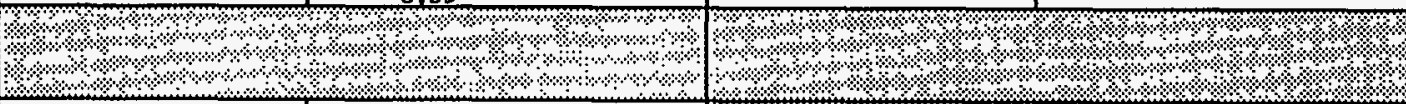 } & (4.) \\
\hline - Labor - Regular & 372.6 & & $4+1$ & 405.6 & ২০০\% \\
\hline - Labor - Overtime & & & +ै. & & (4. \\
\hline 0 Total Labor & 372.6 & & $1 \%+\%+\%$ & 405.6 & ४ै. \\
\hline 1 Materials & 27.0 & & \%. & 27.0 & \% \\
\hline 2 Purchased Services & 5.1 & & \%. & 7.0 & (४⿻े \\
\hline 3 Other Hanford & 15.0 & & ४ै. & & \% \\
\hline 4 Site Services & 19.7 & & 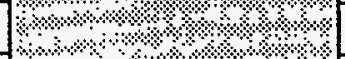 & 16.5 & 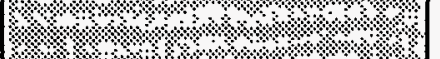 \\
\hline 5 Internal Charges & .0 & & ४ै। & & ४ै। \\
\hline 6 IRM Support & 51.1 & & 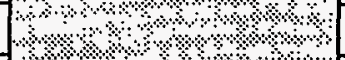 & 31.0 & 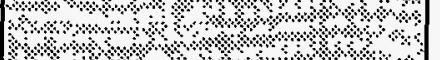 \\
\hline 7 Overheads & 185.6 & & \%ै। & 202.8 & ४ै४ \\
\hline G\&A/SWS Adders & & & ४४४ & & : \\
\hline TOTAL DOLLARS & 675.6 & & & 689.9 & \\
\hline
\end{tabular}


$1 \mathrm{MDBOA}$

COST ACCOUNT

\section{Work Breakdown}

Structure

Dictionary
Westinghouse Hanford Company

Safeguards and Security

Part II - Element Definition
FY 1995 SSO

Revision \#0

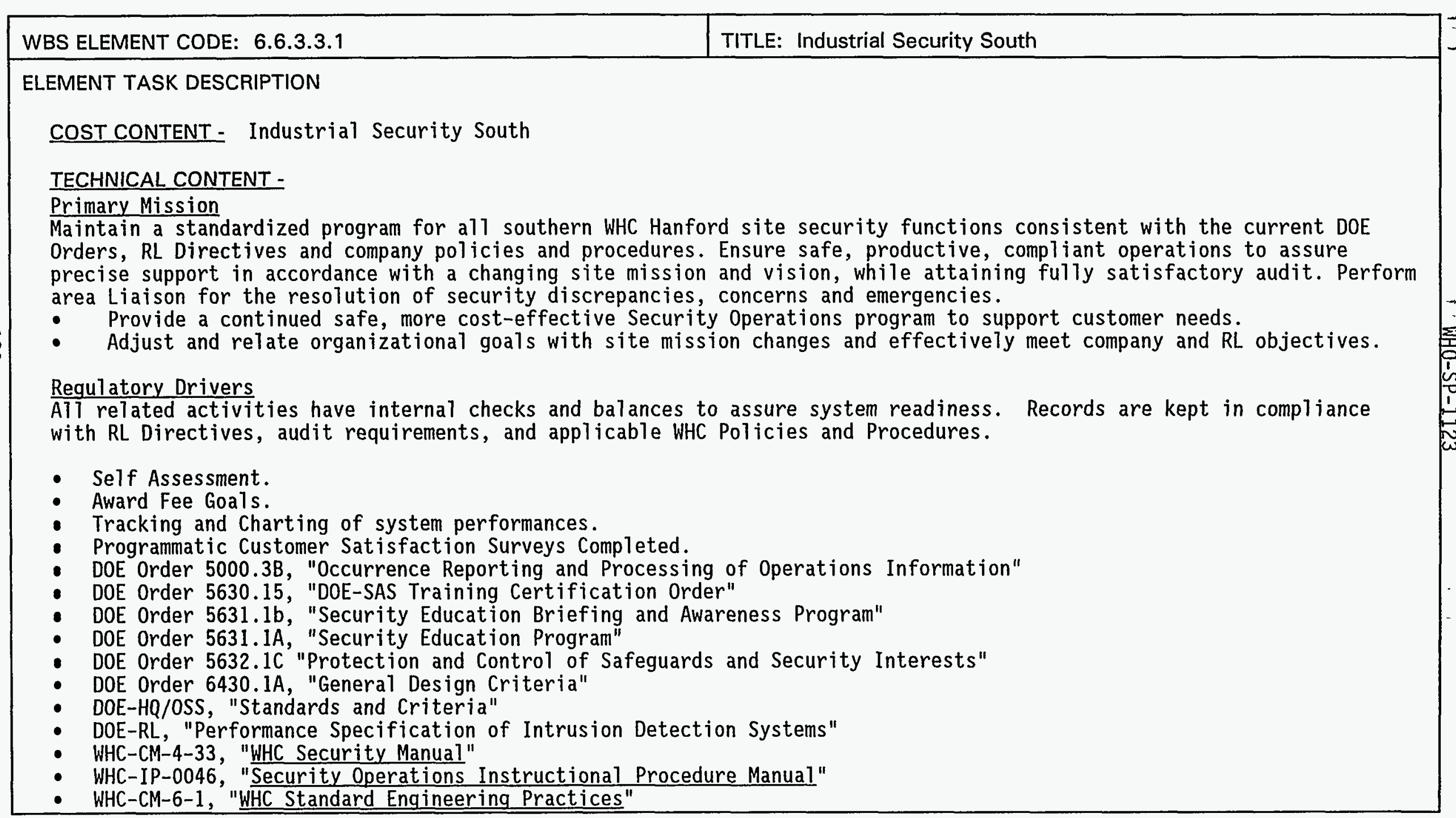


$1 \mathrm{MDBOA}$

\begin{tabular}{|l|l|}
\hline WBS ELEMENT CODE: 6.6 .3 .3 .1 & TITLE: Industrial Security South \\
\hline
\end{tabular}

\section{ELEMENT TASK DESCRIPTION (cont'd)}

\section{OBJECTIVES -}

- Provide Security representation and education to maximize site security efficiency and minimize the generation of Incident Reports.

- Continue to provide specialized security engineering designs, planning and over-view support and approvals for area security systems, projects, facilities and security policy changes.

- Provide systems maintenance, informal status, upgrades and QC/QA per DOE Order requirements for applicable security sensors, systems supporting equipment and facilities. This includes support and response to any needed corrective action for related audits.

- Ensure reasonable employee service access and total accountability of all security Locks and keys for each facility.

- Coordinate WHC compliance with applicable DOE Orders, RLIDs, policies, and procedures.

- Assure compliance with all safety and environmental regulations as they apply to the physical security program.

- Provide support to the Federal Office Building Upgrade Project.

- Provide support to the WHC Outleasing Program.

- Develop and streamline innovative security operations to increase effective teamwork and build a greater level of inter-operational and customer rapport.

- Safely maintain a fully compliant hazardous waste satellite retention center for system and organizational disposal.

- Continue monitoring and reduction of False and Nuisance alarm rates.

\section{ASSUMPTIONS/CONSTRAINTS -}

- Sustain and maximize operational security performance, including the operation of a compliant, effective, preventive and remedial program.

- Continue to review and assure implementation of new orders, directives, and RLIDs.

- Continue to maintain a standardized Security Systems Testing program.

- Access control procedures will be revised to reflect changing mission and/or order requirements.

- All new and deleted work scope impacts not yet identified will be handled via change control.

- Property Protection Areas and Limited Areas will be maintained as required.

- The computer based random search policy will be maintained to support the Patrol random search team.

- Administrative and Craft work space will become more restrictive and geographically less functional.

- Extensive Engineering and Crafts support to implement and service automated entry systems.

- Forced Conversion to the WHC work control and tracking program could result in productivity disruptions and interim work back-logs. 


\begin{tabular}{|c|c|c|}
\hline $\begin{array}{c}1 \mathrm{MDBOA} \\
\text { COST ACCOUNT }\end{array}$ & & \\
\hline $\begin{array}{l}\text { Work Breakdown } \\
\text { Structure } \\
\text { Dictionary }\end{array}$ & $\begin{array}{l}\text { Westinghouse Hanford Company } \\
\text { Safeguards and Security } \\
\text { Part II - Element Definition (continued) }\end{array}$ & $\begin{array}{l}\text { FY } 1995 \text { SSSP } \\
\text { Revision \#0 }\end{array}$ \\
\hline
\end{tabular}

\begin{tabular}{|l|l}
\hline WBS ELEMENT CODE: 6.6 .3 .3 .1 & TITLE: Industrial Security South
\end{tabular}

\section{ELEMENT TASK DESCRIPTION (cont'd)}

\section{MILESTONES -}

The Program has not identified specific milestones for this funding source.

\section{DELIVERABLES -}

- Provide timely response and completion of all Priority Work Requests.

- Develop, review and complete Preventive Maintenance (PM) routines per PM Procedures and frequencies.

- Provide specialized security technical guidance, engineering and maintenance to program departments in the southern area.

- Ensure systems and sensor performance are compliant and consistent with DOE Orders, WHC Policies and Procedures through Performance Review and configuration control.

- Provide; Site facilities security evaluation reviews, reporting support and Asset protection checks.

- Support the development Hanford Security Interest Maps - Documents locations of security interests and limited areas.

- Award Fee Input - Provide input to RL in development of Contractor Award Fee.

- RL Survey Program support.

- WHC Site Selection Task Group - Support project reviews.

- WHC Controlled Manual Reviews.

- Performance Indicators - Develop program performance indicators.

- Program Organization - Develop plan to address physical security organization and workscope.

- Implement revised RLID 5632.1B, "Asset Protection Requirements."

- Provide support for Emergency Response Centers.

- Provide a sensor testing program that includes evaluation/validation of established security standards. 


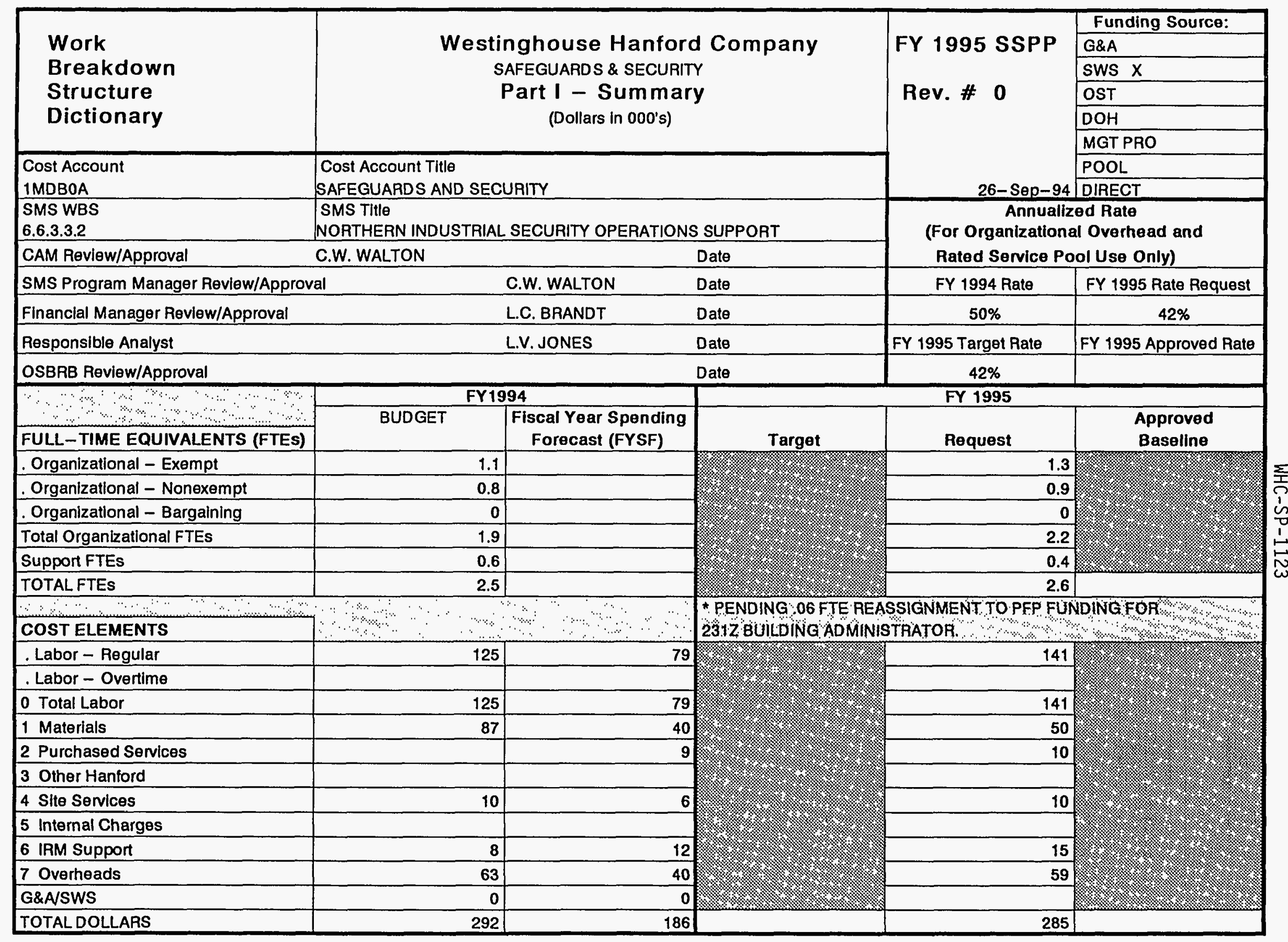




\begin{tabular}{|l|c|c|}
\hline $\begin{array}{l}\text { IMDBOA } \\
\text { COST ACCOUNT }\end{array}$ & \multicolumn{2}{|c|}{ FY 1995 SSSP } \\
\hline $\begin{array}{l}\text { Work Breakdown } \\
\text { Structure } \\
\text { Dictionary }\end{array}$ & Westinghouse Hanford Company & Revision \#0 \\
\hline
\end{tabular}

\begin{tabular}{|l|l|}
\hline WBS ELEMENT CODE: 6.6 .3 .3 .2 & TITLE: NORTHERN SECURITY OPERATIONS SUPPORT FOR INDUSTRIAL \\
SECURITY OPERATIONS
\end{tabular}

\section{ELEMENT TASK DESCRIPTION}

COST CONTENT - Develop and administer security support for all 600-N and Industrial Security facility needs, including the coordination of all physical security issues, key control, and security education.

TECHNICAL CONTENT - According to applicable DOE Orders and Company Directives, provide specialized physical security protection guidance, security educational training, engineering, and key accountability control.

OBJECTIVES - Provide appropriate specialized staffing to support site facilities' security requirements. Adjust organizational goals as needed to meet site mission changes. Provide security representation and engineering reviews for project designs, as well as overview and approvals for facility sitings and projects. Direct or approve facility security policy needs and changes.

ASSUMPTIONS/CONSTRAINTS - Continued RLID facility security check-list implementation will require consistent support to ensure applicable facility protection is arranged and maintained.

MILESTONES - None

DELIVERABLES - Provide a comprehensive physical security program support for al1 600 North Area WHC facilities and Industrial Security needs, inciuding security engineering, security key control program and educational support. 


\begin{tabular}{|c|c|c|c|c|c|}
\hline \multirow{6}{*}{$\begin{array}{l}\text { Work } \\
\text { Breakdown } \\
\text { Structure } \\
\text { Dictionary }\end{array}$} & \multirow{6}{*}{\multicolumn{3}{|c|}{$\begin{array}{c}\text { Westinghouse Hanford Company } \\
\text { Safeguards and Security } \\
\text { Part I - Summary } \\
\text { (Dollars in } 000^{\prime} \text { s) }\end{array}$}} & \multirow{8}{*}{$\begin{array}{l}\text { FY1995 SSSP } \\
\text { Rev. \#0 }\end{array}$} & Funding Source: \\
\hline & & & & & G\&A \\
\hline & & & & & sws \\
\hline & & & & & OST \\
\hline & & & & & DOH \\
\hline & & & & & MGT PRO \\
\hline \multirow{2}{*}{$\begin{array}{l}\text { Cost Account } \\
1 \mathrm{MDBOA}\end{array}$} & \multirow{2}{*}{\multicolumn{3}{|c|}{$\begin{array}{l}\text { Cost Account Title } \\
\text { Safeguards and Security }\end{array}$}} & & POOL \\
\hline & & & & & DIRECT \\
\hline $\begin{array}{l}\text { SMS WBS } \\
6.6 .3 .3 .3\end{array}$ & \multicolumn{3}{|c|}{$\begin{array}{l}\text { SMS ritle } \\
\text { Industrial Security Administration }\end{array}$} & \multirow{2}{*}{\multicolumn{2}{|c|}{$\begin{array}{c}\text { Annual ized Rate } \\
\text { (For Organizational Overhead } \\
\text { and Rated Service Pool Use Only) }\end{array}$}} \\
\hline \multicolumn{3}{|l|}{ CAM Review/Approval: C. H. Walton } & Date & & \\
\hline \multicolumn{3}{|c|}{ SMS Program Manager Review/Approval: D. J. Haskins } & Date & FY 1994 Rate & FY 1995 Rate Request \\
\hline \multicolumn{3}{|c|}{ Financial Manager Review/Approval: L. C. Brandt } & Date & & \\
\hline \multicolumn{3}{|c|}{ Responsible Analyst: P. S. Ripley } & Date & FY 1995 Target Rate & FY 1995 Approved Rate \\
\hline \multicolumn{3}{|l|}{ OSBRB Review/Approval } & Date & & \\
\hline \multirow{2}{*}{ (ै) } & \multicolumn{2}{|r|}{ FY1994 } & \multicolumn{3}{|c|}{ FY1995 } \\
\hline & \multirow[b]{2}{*}{ Budget } & \multirow{2}{*}{$\begin{array}{c}\text { Fiscal Year Spending } \\
\text { Forecast (FYSF) }\end{array}$} & \multirow[b]{2}{*}{ Target } & \multirow[b]{2}{*}{ Request } & \multirow{2}{*}{$\begin{array}{l}\text { Approved } \\
\text { Basel ine }\end{array}$} \\
\hline FULL-TIME EQUIVALENTS (FTES) & & & & & \\
\hline - Organizat ional - Exempt & $4.5^{*}$ & & \multirow{5}{*}{ 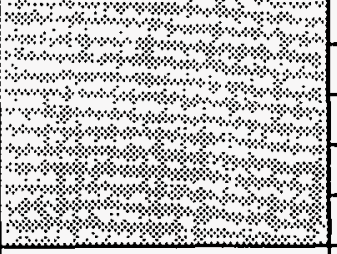 } & 3.7 & \multirow{5}{*}{ 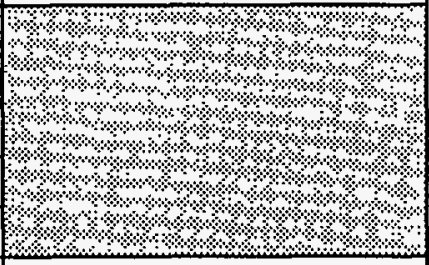 } \\
\hline - Organizational - Non Exempt & 1.0 & & & 1.0 & \\
\hline \multicolumn{3}{|l|}{ - Organizational - Bargaining } & & \multirow{3}{*}{4.7} & \\
\hline Total Organizational FTEs & \multirow[t]{2}{*}{5.5} & & & & \\
\hline Support FTEs & & & & & \\
\hline TOTAL FTES & 5.5 & & & 4.7 & \\
\hline COST ELEMENTS & \% & 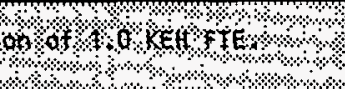 & $18+2 .+\%$ & 1. & \%ै. \\
\hline - Labor - Regular & 250.4 & & $1 \%$ (2. & 272.9 & ४ै। \\
\hline - Labor - Overtime & & & $1 \%+\%$ & & ?. \\
\hline 0 Total Labor & 250.4 & & \% & 272.9 & \\
\hline 1 Materials & 19.4 & & $19+\%$ & 10.0 & \\
\hline 2 Purchased Services & 10.0 & & 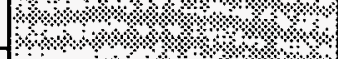 & 10.0 & \% \\
\hline 3 other Hanford & & & \% & & $12 \%$ \\
\hline 4 site Services & 4.0 & & $1+\%$ & 4.0 & 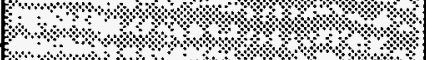 \\
\hline 5 Internal charges & & & $1 \%+2$ & & ॰ \\
\hline $6 \quad$ IRM Support & 18.0 & & $\mathrm{H}+{ }^{\circ}+{ }^{\circ}$ & 8.5 & $\%$ \\
\hline 7 Overheads & & & $13+$ & 114.6 & \\
\hline GBA/SWS Adders & & & $1 \%$ & & 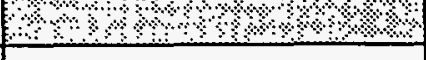 \\
\hline TOTAL DOLLARS & 301.8 & & & 420.0 & \\
\hline
\end{tabular}




\begin{tabular}{|c|c|c|}
\hline $\begin{array}{c}1 \mathrm{MDBOA} \\
\text { COST ACCOUNT }\end{array}$ & & \\
\hline $\begin{array}{l}\text { Work Breakdown } \\
\text { Structure } \\
\text { Dictionary }\end{array}$ & $\begin{array}{c}\text { Westinghouse Hanford Company } \\
\text { Safeguards and Security } \\
\text { Part II - Element Definition }\end{array}$ & $\begin{array}{l}\text { FY } 1995 \text { SSSP } \\
\text { Revision \#0 }\end{array}$ \\
\hline
\end{tabular}

\begin{tabular}{|l|l|}
\hline WBS ELEMENT CODE: 6.6 .3 .3 .3 & TITLE: Industrial Security Administration \\
\hline
\end{tabular}

ELEMENT TASK DESCRIPTION

COST CONTENT - Industrial Security Administration

TECHNICAL CONTENT -

\section{Primary Mission}

- Develop and implement an industrial security program for all property protection areas and limited areas on the Hanford Site.

- Coordinate like tasks and standardize, where appropriate, physical security programs for the Hanford Site.

- Provide administrative support as required, for the protection of SNM at PFP, FFTF, and 100-K Basins.

\section{Regulatory Drivers}

Regulatory drivers to support this funding source are as follows:

- DOE Order 5632.1C, "Protection and Control of Safeguards and Security Interests"

- DOE Order 5632.1C-1, "Manual for the Protection and Control of Safeguards and Security Interests"

- DOE Order 5639.6, "Classified computer Security Program"

- DOE Order 6430,1A, "General Design Criteria"

- DOE-HQ/OSS Standards and Criteria

- RLID 5632.1A, "Asset Protection Requirements"

- RL N 5632. IMA, "Design, Installation and Evaluation of Interior Motion Alarm Systems"

- RL N 5632.LK, "Lock and Key Control"

- SAS-92-02, "Hanford Site Safeguards and Security Performance Specification: Field Testing Criteria for Entry/Exit Control Screening Devices"

- WHC-CM-4-33, "WHC Security Manual"

- WHC-CM-6-2, "Project Management"

- WHC-CM-6-12, "Project Department Procedures"

- WHC-IP-0046, "Safequards and Security Systems Manual" 
$1 \mathrm{MDBOA}$

COST ACCOUNT

Work Breakdown
Structure
Dictionary
Westinghouse Hanford Company
Safeguards and Security
Part II - Element Definition (continued)

FY 1995 SSSP

Revision \#0

\begin{tabular}{|l|l|}
\hline WBS ELEMENT CODE: 6.6 .3 .3 .3 & TITLE: Industrial Security Administration \\
\hline ELEMENT TASK DESCRIPTION (cont'd) \\
OBJECTIVES - \\
- Maintain a standardized Physical Security, Security Systems Testing, Project reviews, and Security Systems \\
- Maintenance and Engineering Programs on the Hanford Site. \\
- Provide physical security interface with RL Safeguards and Security. \\
- Coordinate WHC compliance with applicable DOE Orders, RLIDs, policies, and procedures. \\
- Assure compliance with all safety and environmental regulations as they apply to the physical security program. \\
- Provide Task Team support for the PFP VSIS, NMSS, and AMS Replacement Study. \\
- Provide oversight to resolution of Tank Farm conduct of operations issues. \\
- Provide support to the SAS/PPG Committee. \\
- Provide support to the Federal Office Building Upgrade Project. \\
- Provide support as necessary to resolve outstanding STPO initiatives. \\
Provide review and assure implementation of new orders, directives, and RLIDs.
\end{tabular}

\section{ASSUMPTIONS/CONSTRAINTS -}

- Access control procedures will be revised to reflect changing mission and/or order requirements.

- Al1 new and deleted work scope impacts not yet identified will be handled via change control.

- Property Protection Areas and Limited Areas will be maintained as required.

- The computer based random search policy will be maintained to support the Patrol random search team.

- Staff support will be provided for an Security Evaluation review of the Hanford Site in FY 1995.

- Implementation of DOE Order 5632.1C-1. This Order will require changes to the physical security program.

- There will be RL visits that will require staff support.

\section{MILESTONES -}

None 


\begin{tabular}{|l|c|c|}
\hline \multicolumn{1}{|c|}{$\begin{array}{l}\text { 1MDBOA } \\
\text { COST ACCOUNT }\end{array}$} & Westinghouse Hanford Company & FY 1995 SSSP \\
\hline $\begin{array}{l}\text { Work Breakdown } \\
\text { Structure } \\
\text { Dictionary }\end{array}$ & Safeguards and Security & Revision \#0 \\
\hline
\end{tabular}

\begin{tabular}{|l|l|}
\hline WBS ELEMENT CODE: 6.6 .3 .3 .3 & TITLE: Industrial Security Administration \\
\hline ELEMENT TASK DESCRIPTION (cont'd) \\
DELIVERABLES -
\end{tabular}

- Maintain the multi-contractor Hanford Security Interest Maps to document locations of security interests and 1 imited areas. Submit to RL every 6 months (January and July).

- DOE Order and RLID reviews.

- RL Survey Program support.

- WHC Site Selection Task Group - Coordinate project reviews.

- WHC Controlled Manual Reviews.

- Performance Indicators - Develop program performance indicators.

- Program Organization - Develop plan to address physical security organization and workscope.

- Maintain Asset Protection Requirements Program. 


\section{Work \\ Breakdown \\ Structure \\ Dictionary}

\section{Cost Account}

$1 M D B 0 A$

SMS WBS

6.6.3.4

CAM Review/Approval

SMS Program Manager Revlew/Approval

Financlal Manager Review/Approval

Responsible Analyst

OSBRB Review/Approval

FULL-TIME EQUIVALENTS (FTES)

Organizational - Exempt

. Organizational - Nonexempt

. Organizational - Bargaining

Total Organizational FTEs

Support FTEs

TOTAL FTES

TOTALFTES . . . . . . . .

COST ELEMENTS

. Labor - Regular

. Labor - Overtime

o Total Labor

1 Materials

2 Purchased Services

3 Other Hanford

4 Site Services

5 Internal Charges

6 IRM Support

7 Overheads

TOTAL DOLLARS
Westinghouse Hanford Company

SAFEGUARDS \& SECURITY

Part I - Summary

(Dollars in 000's)

Cost Account Title

SAS

SMS Title

RAD/TOX SAB ASSESSMENT - RISK ASSESSMENT \& EVALUATION C.W. WALTON

\section{val}

Date

L.C. BRANDT

L.V. JONES

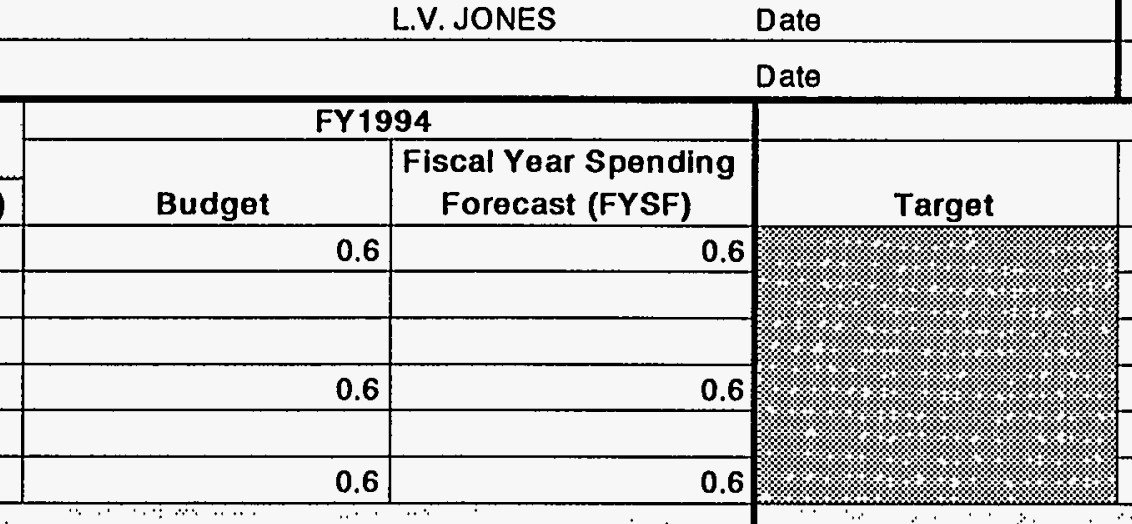

FY 1995 SSPP

Rev. \# 0

G\&A

SWS $x$

OST

DOH

MGT PRO

POOL

26-Sep-94 DIRECT

Annualized Rate

(For Organizational Overhead and Rated Service Pool Use Only) FY 1994 Rate FY 1995 Rate Request FY 1995 Target Rate FY 1995 Approved Rate $42 \%$

FY 1995

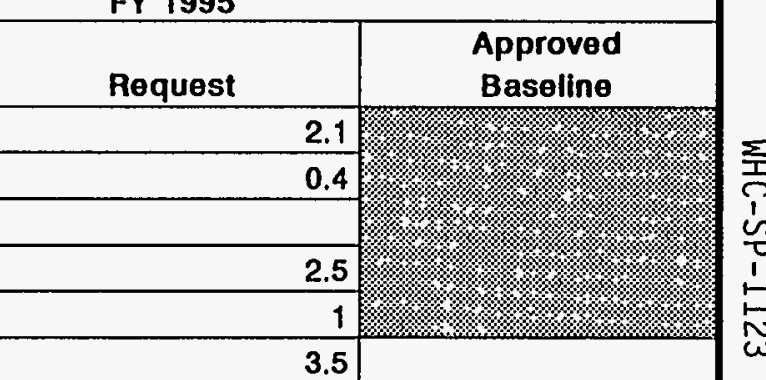


COST ACCOUNT

\begin{tabular}{l|c} 
Work Breakdown & Westinghouse Hanford Company \\
Structure & Safeguards \& Security \\
Dictionary & Part II - Element Definition
\end{tabular}

FY 1995 SSSP

Dictionary

TITLE: RAD/TOX SABOTAGE

WBS ELEMENT CODE: 6.6.3.4

Revision \#0

\section{ELEMENT TASK DESCRIPTION}

\section{COST CONTENT -}

Funding from SWS. In FY 1994, one assessment was initiated with the bulk of the assessments to be completed in FY 1995 and FY 1996. The expected number of assessments to be completed in FY 1995 are six. This is the major driver behind the increase of cost for this activity in FY 1995.

\section{TECHNICAL CONTENT -}

Complete six facility radiological/toxicological sabotage assessments during $F Y 1995$ to meet the requirements of DOE N 5630.3A, "Protection of Departmental Facilities Against Radiological and Toxicological Sabotage," and D0E Order 5630.14A, "Safeguards and Security Program Planning."

\section{OBJECTIVES -}

Complete the sabotage assessments to determine the risk to the health and safety of the public and plant employees. If risk is not low and acceptable, determine mitigating actions required to achieve low and acceptable risks.

Vu7lnerability Analysius Reports (VAR) will be included as supplements to the Hanford Site Hazard Assessments. Conduct validation testing as required if upgrades are implemented to reduice risk to acceptable 13evels. Input results in the Hanford Site Safeguard and Security Plan if required.

\section{ASSUMPTIONS/CONSTRAINTS -}

Sabotage assessments are to be based on priority radiological and toxicological interests at Hanford. The milestone schedule includes the priority of worst case facilities and locations.

\section{MILESTONES -}

Complete the six assessments by September 30, 1995 .

\section{DELIVERABLES -}

1. B-P1 ant/WESF report-12/94

2. Lampre Solid Waste report-2/95

3. 327 Facility report-4/95 


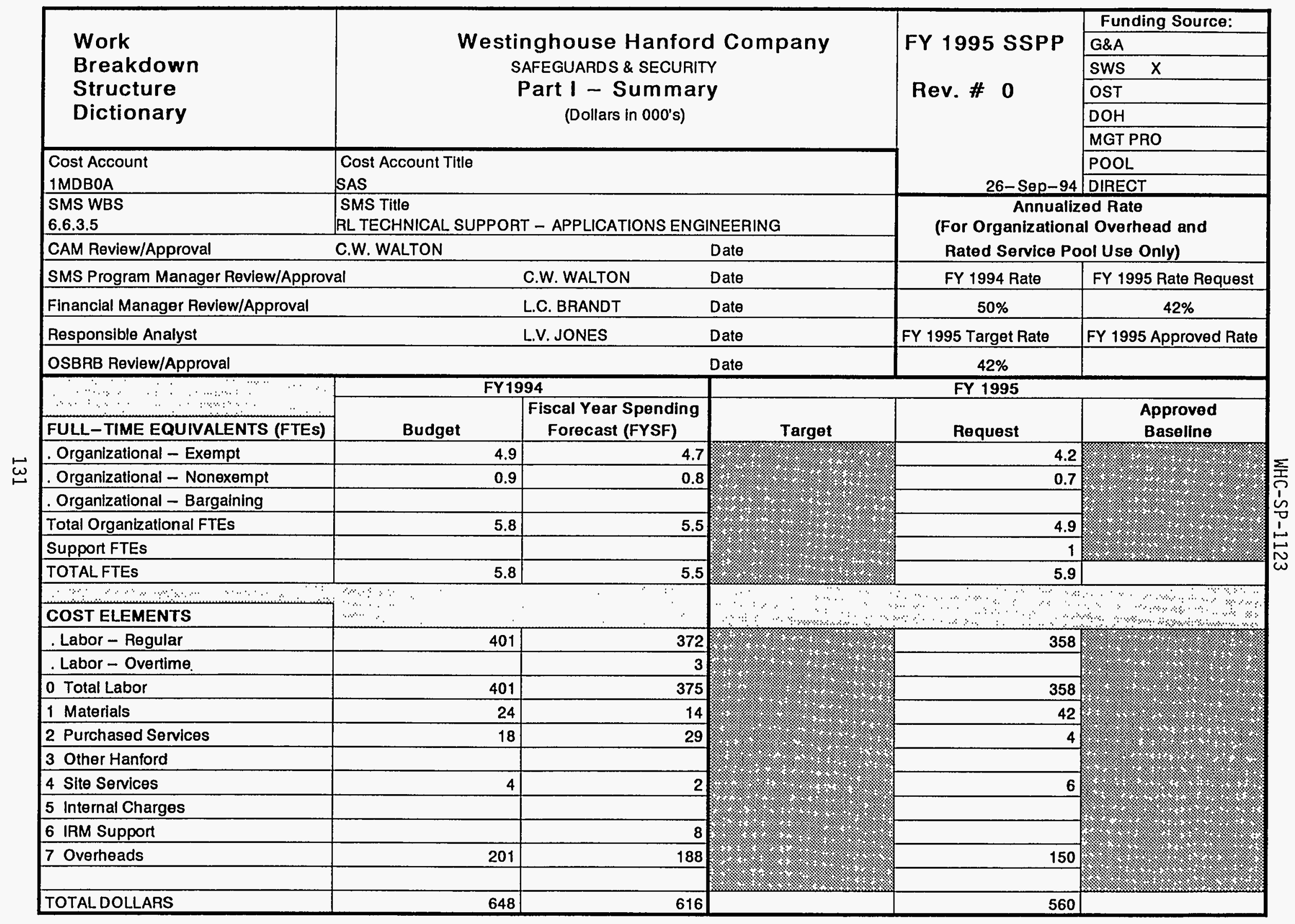


COST ACCOUNT

\section{Work Breakdown}

Structure

Dictionary
Westinghouse Hanford Company

Security Operations Administration

Part II - Element Definition
FY 1995 SSSP

Revision \#0

WBS ELEMENT CODE: $6 \cdot 6.3 .5$

TITLE: RL Technical Support

ELEMENT TASK DESCRIPTION

COST CONTENT - CSP Funded Sitewide Support

TECHNICAL CONTENT - Technical and administrative support to the DOE-RL SAS staff. This element provides the qualified staff to help evaluate and implement the evolving SAS requirements.

OBJECTIVES - Assist RL in planning the Hanford Site implementation of DOE Order 5630.15 for SAS training. Coordinate the update of Hanford Site SAS Training Program Implementation PIan.

Provide technical review of changing DOE Orders and assess the cost and procedural impact to DOE-RL SAS.

Update the Hanford SSSP and provide the necessary review cycle to ensure DOE approval.

Evaluate cost effective SAS technologies and provide guidance on their implementation.

Prepare a Hanford process to compare Risk Management with DOE Order compliance.

ASSUMPTIONS/CONSTRAINTS - Assumptions

As the fiscal year progresses, there will be various changes to DOE Orders that RL will be asked to review and comment on. The diverse subject matter will require review by various experts. Direct support to RL is necessary to ensure that critical needs are continually met while changes are made in the process.

MILESTONES - Complete SSSP which includes SSMR and VAR for facilities with CAT I and II SNM and radiological/toxicological interests. The draft report will be submitted to DOE-RL September 30 , 1995 for review and comment.

DELIVERABLES - Test $\mathrm{plans}$ and test reports for work in the area of cost effective technology. White paper on the subject to Risk Management versus DOE Order compliance. 


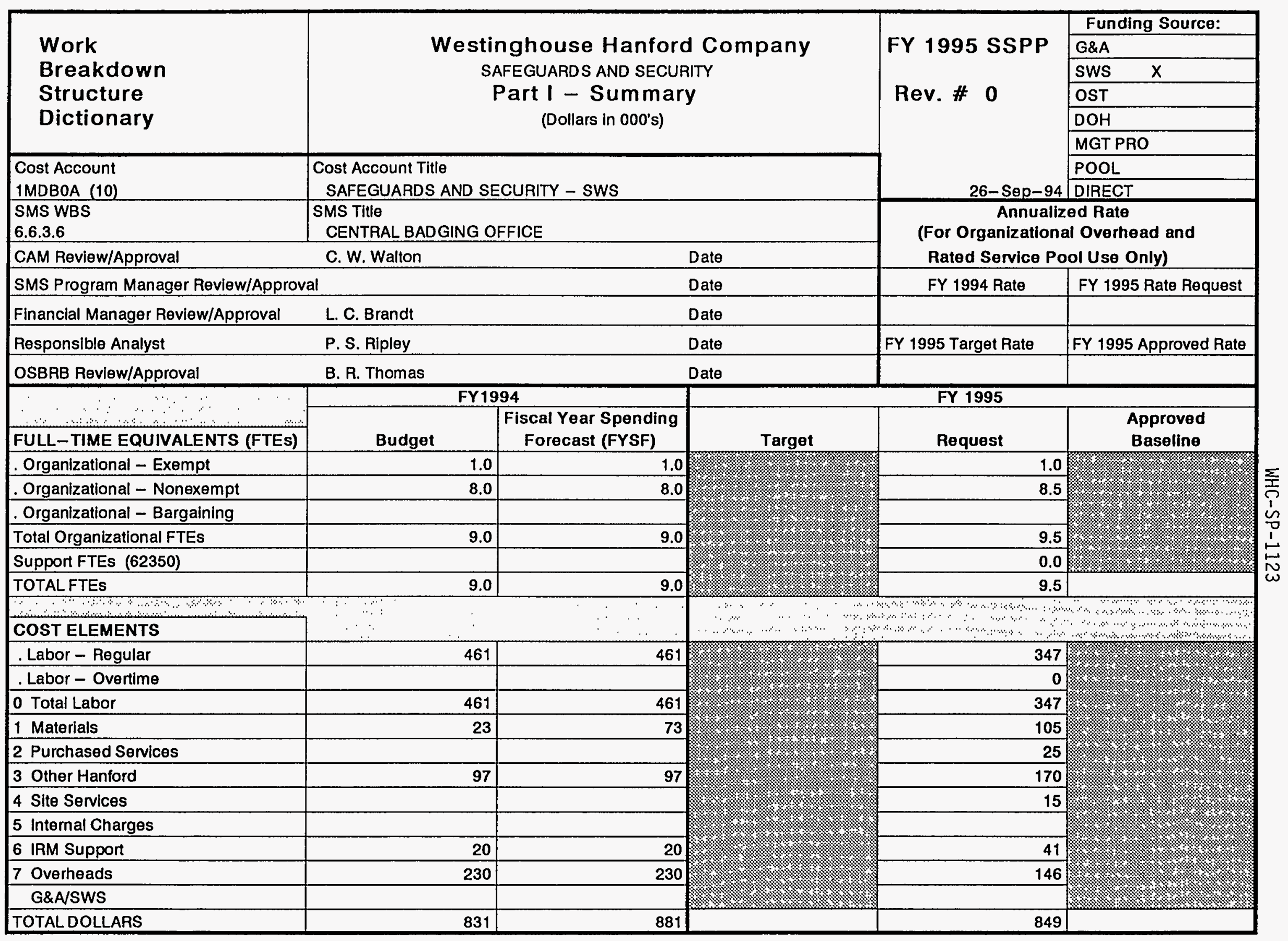




\begin{tabular}{|c|c|c|}
\hline $\begin{array}{l}\text { 1MDBOA } \\
\text { COST ACCOUNT }\end{array}$ & & \\
\hline $\begin{array}{l}\text { Work Breakdown } \\
\text { Structure } \\
\text { Dictionary }\end{array}$ & $\begin{array}{c}\text { Westinghouse Hanford Company } \\
\text { Safeguards and Security } \\
\text { Part II - Element Definition }\end{array}$ & $\begin{array}{l}\text { FY95 SSSP } \\
\text { Revision \#C }\end{array}$ \\
\hline
\end{tabular}

\begin{tabular}{|l|l|}
\hline WBS ELEMENT CODE: $\quad 6.6 .3 .6$ & TITLE: Central Badging \\
\hline ELEMENT TASK DESCRIPTION &
\end{tabular}

ELEMENT TASK DESCRIPTION

COST CONTENT -

SWS

TECHNICAL CONTENT -

DOE 5632.1C Protection and Control of Safeguards and Security Interests

Staffing levels will decrease as work is reduced or transferred out of SAS

MILESTONES -

Complete Sitewide rebadging project by January 31, 1995

DELIVERABLES -

Excellent service for customers requesting badges and special access. 
ELEMENT TASK DESCRIPTION

\section{WORK STATEMENT -}

Activity Detalled Description - HANFORD PATROL

Physically protect Special Nuclear Material, classified information,

U.S. Government property, and personnel as a service to SWS.

$\vec{\omega}$

Activity Detalled Description - INDUSTRIAL SECURITY

Provide security representation, engineering reviews, perform systems engineering and maintenance, direct and approve facility security policy needs and changes for all Hanford Site common areas.

Tests SAS Systems in a manner that meets DOE Orders, federal and state regulations, and WHC Company policies. This activity identifies and develops workable solutions to SAS issues.

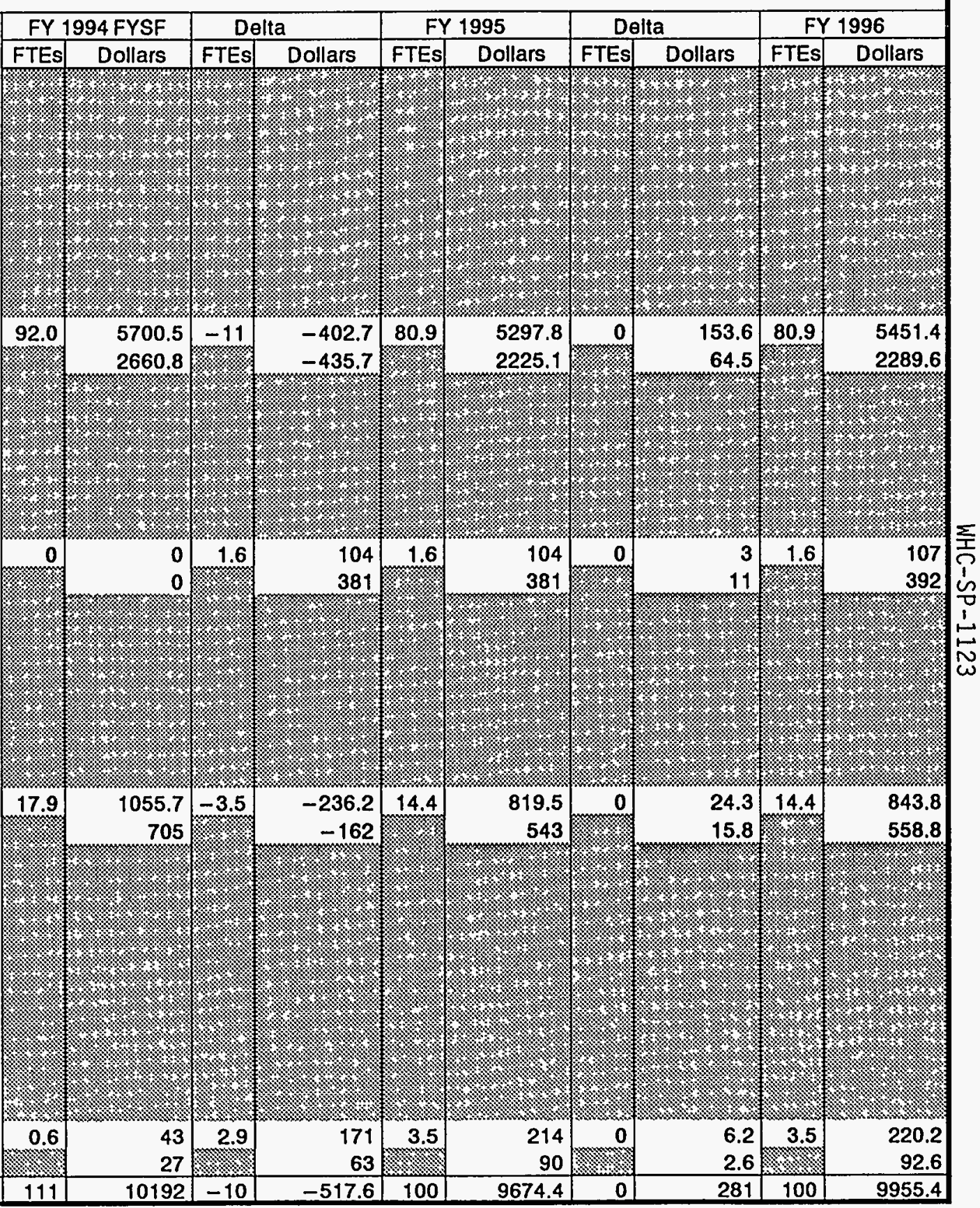

Activity Detailed Description - RAD/TOX SABOTAGE

Complete the sabotage assessments to determine the risk to the health and safety of the public and Hanford Site employees.

Determine mitigating actions required to achieve low and acceptable risks. 


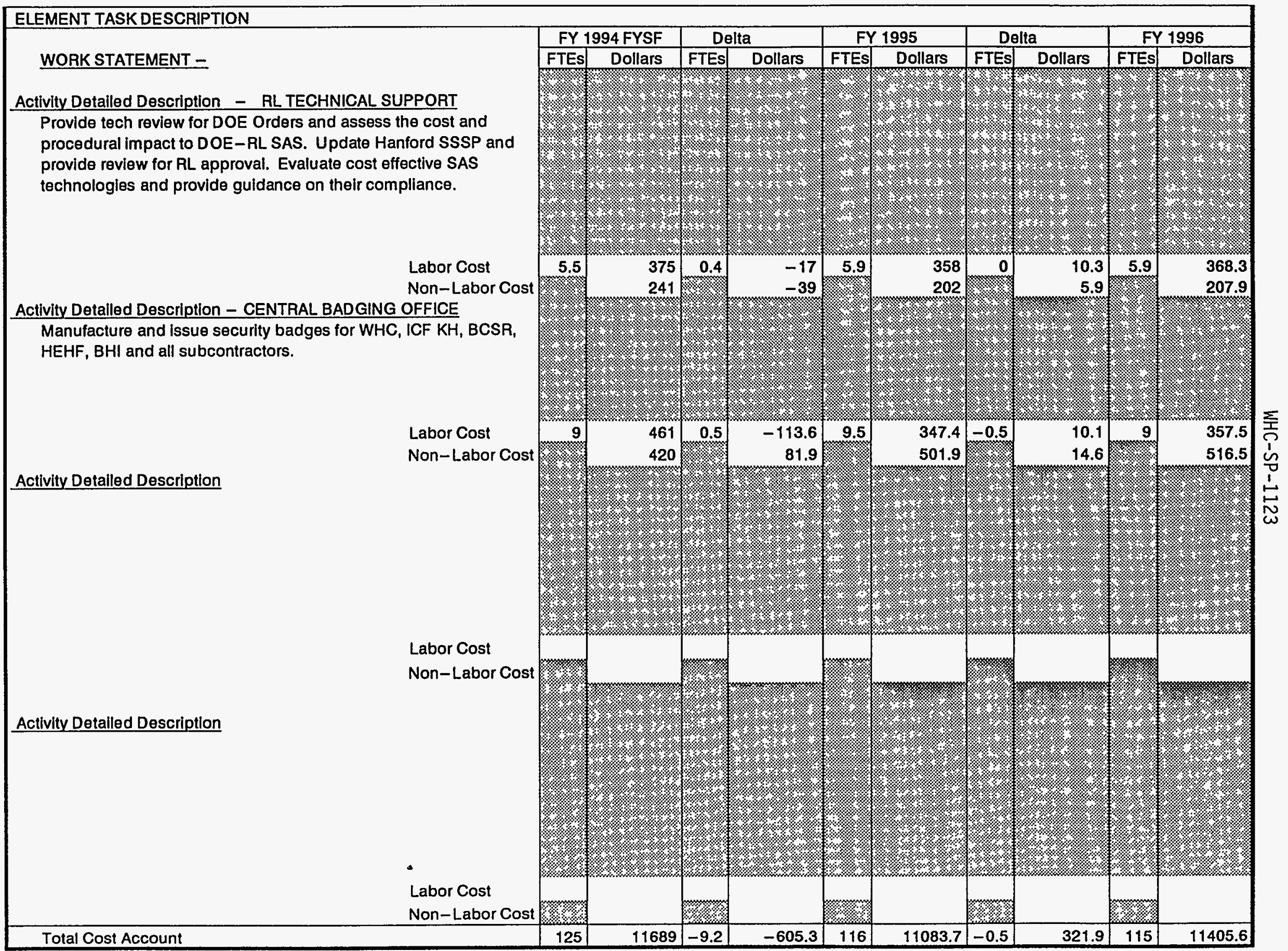




\begin{tabular}{|c|c|c|c|c|c|}
\hline \multirow{6}{*}{$\begin{array}{l}\text { Work } \\
\text { Breakdown } \\
\text { Structure } \\
\text { Dictionary }\end{array}$} & \multirow{6}{*}{\multicolumn{3}{|c|}{$\begin{array}{c}\text { Westinghouse Hanford Company } \\
\text { Safeguards and Security } \\
\text { Part I - Summary } \\
\text { (Dollars in 000's) }\end{array}$}} & \multirow{8}{*}{$\begin{array}{l}\text { FY1995 SSSP } \\
\text { Rev. \#0 }\end{array}$} & Funding Source: \\
\hline & & & & & G\&A \\
\hline & & & & & SWS \\
\hline & & & & & OST \\
\hline & & & & & DOH \\
\hline & & & & & MGT PRO \\
\hline \multirow{2}{*}{$\begin{array}{l}\text { Cost Account } \\
\text { 1MDAOV }\end{array}$} & \multirow{2}{*}{\multicolumn{3}{|c|}{$\begin{array}{l}\text { Cost Account Title } \\
\text { Safeguards and Security }\end{array}$}} & & POOL \\
\hline & & & & & DIRECT \\
\hline $\begin{array}{l}\text { SMS HBS } \\
6.6 .4\end{array}$ & \multicolumn{3}{|c|}{$\begin{array}{l}\text { SMS ritle } \\
\text { Locksmith Services }\end{array}$} & \multirow{2}{*}{\multicolumn{2}{|c|}{$\begin{array}{l}\text { Annual ized Rate } \\
\text { (For Organizational Overhead } \\
\text { and Rated Service Pool Use Only) }\end{array}$}} \\
\hline \multicolumn{3}{|l|}{ CAM Review/Approval: C. W. Walton } & $\overline{\text { Date }}$ & & \\
\hline \multicolumn{2}{|c|}{ SMS Program Manager Review/Approval: D. J. Haskins } & & Date & FY 1994 Rate & FY 1995 Rate Request \\
\hline \multicolumn{2}{|c|}{ Financial Manager Review/Approval: L. C. Brandt } & & Date & & \\
\hline \multicolumn{2}{|l|}{ Responsible Analyst: P. S. Ripley } & & Date & FY 1995 Target Rate & FY 1995 Approved Rate \\
\hline \multicolumn{2}{|l|}{ OSBRB Review/Approval } & & Date & & \\
\hline \multirow{2}{*}{ \% } & \multicolumn{2}{|c|}{ FY1994 } & \multicolumn{3}{|c|}{ FY1995 } \\
\hline & & Fiscal Year Spending & \multirow[b]{2}{*}{ Target } & \multirow[b]{2}{*}{ Request } & \multirow{2}{*}{$\begin{array}{l}\text { Approved } \\
\text { Baseline }\end{array}$} \\
\hline FULL-TIME EQUIVALENTS (FTES) & Budget & Forecast (FYSF) & & & \\
\hline - Organizational - Exempt & 1.5 & & \multirow{5}{*}{ 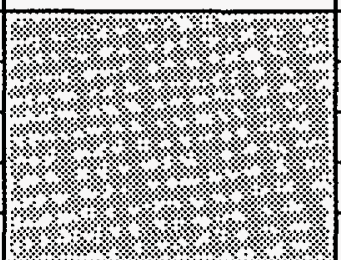 } & 1.3 & \multirow{5}{*}{ 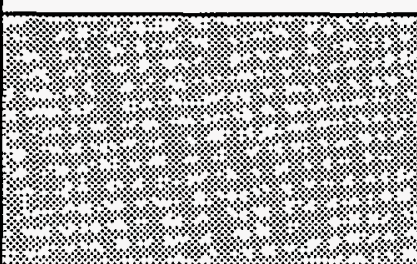 } \\
\hline - Organizational - Non Exempt & & & & & \\
\hline - Organizational - Bargaining & 5.0 & & & 5.0 & \\
\hline Total Organizational FTEs & 6.5 & & & 6.3 & \\
\hline Support FTES & 0.6 & & & 0.4 & \\
\hline TOTAL FTES & 7.1 & & & 6.7 & \\
\hline COST ELEMENTS & $1 \%$ & ४ & $14 \%$ & (1.1. & $4+\%+\%+\%$ \\
\hline $\begin{array}{l}\text { COST ELEMENTS } \\
\text { Labor - Regular }\end{array}$ & $\frac{28.28}{447.5}$ & & $14 \%$ & $\frac{4.8}{410.6}$ & H) \\
\hline - Labor - Overtime & 10.0 & & (।. & 410.0 & \%. \\
\hline 0 Total Labor & 457.5 & & 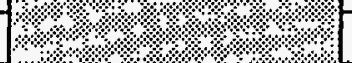 & 420.6 & \% \\
\hline 1 Materials & 171.5 & & 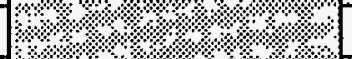 & 214.0 & \%. . \\
\hline 2 Purchased Services & 6.2 & & ?. & 8.0 & ४ै. \\
\hline 3 other Hanford & & & 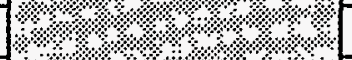 & & ४ै. \\
\hline 4 Site Services & 84.5 & & (.) & 43.5 & \\
\hline 5 Internal Charges & 32.0 & & \% & & \\
\hline 6 IRM Support & 3.0 & & ४् & 3.0 & \\
\hline 7 Ovorhoads & 16.3 & & & 176.8 & \\
\hline GRA/SWS Adders & & & 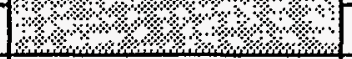 & & 2 \\
\hline TOTAL DOLLARS & 771.0 & & & 866.0 & \\
\hline
\end{tabular}




\begin{tabular}{|c|c|c|}
\hline $\begin{array}{c}1 \text { MDAOV } \\
\text { COST ACCOUNT }\end{array}$ & & \\
\hline $\begin{array}{l}\text { Work Breakdown } \\
\text { Structure } \\
\text { Dictionary }\end{array}$ & $\begin{array}{c}\text { Westinghouse Hanford Company } \\
\text { Safeguards and Security } \\
\text { Part II - Element Definition }\end{array}$ & $\begin{array}{l}\text { FY } 1995 \text { SSSP } \\
\text { Revision \#0 }\end{array}$ \\
\hline
\end{tabular}

\begin{tabular}{|l|l|}
\hline WBS ELEMENT CODE: 6.6 .4 & TITLE: Locksmith Services \\
\hline ELEMENT TASK DESCRIPTION \\
COST CONTENT - Locksmith Services - Self Liquidating Pool (SLP) \\
Cost Distribution Method--Locksmith services are distributed by a predetermined hourly rate, based on actual expended \\
hours, plus appl icable direct material costs. The rate is determined by dividing the locksmith operations budget by the \\
estimated annual billable hours of the locksmiths.
\end{tabular}

\section{TECHNICAL CONTENT -}

\section{Primary Mission}

- Coordinate Site Locksmith services, ensuring its operations are conducted in accordance with DOE and WHC policies and applicable bargaining unit agreements.

\section{Regulatory Drivers}

Regulatory drivers to support this funding source are as follows:

- DOE Order 5632.1C, "Physical Protection of Safeguards and Security Interests"

- DOE Order 6430.1A, "General Design Criteria"

- DOE M 5632.1C-1, "Manual for Physical Protection of Safeguards and Security Interests"

- RLID 5632.1A, "Asset Protection Requirements"

- RLID 5632.5, "Physical Protection of Classified Matter"

- RLID 5632.6, "Physical Protection of DOE Property and Unclassified Facilities"

\section{OBJECTIVES -}

- Assure Locksmith Services are provided to all Hanford Site and WHC leased facilities.

- Assure Locksmith work is performed in compliance with all safety, environmental, and OSHA regulations.

- Assure all security keys are issued and accounted for in accordance with WHC-IP-0908, "Key Control Clerk Procedure." 
$1 \mathrm{MDAOV}$

COST ACCOUNT

Work Breakdown

Structure

Dictionary
Westinghouse Hanford Company

Safeguards and Security

Part II - Element Definition
FY 1995 SSSP

Revision \#0

\begin{tabular}{|l|l|}
\hline WBS ELEMENT CODE: 6.6 .4 & TITLE: Locksmith Services \\
\hline
\end{tabular}

ELEMENT TASK DESCRIPTION

\section{ASSUMPTIONS/CONSTRAINTS -}

- Provide reviews of new orders, directives, and RLIDs.

- Locksmith work wil1 increase to support comp1 iance with RLID 5632.1B, "Asset Protection Requirements."

- Safely maintain a fully compliant hazardous waste satellite retention center for system and organizational disposal.

MILESTONES -

No milestones are established for this funding source.

\section{DELIVERABLES -}

- Locksmith Services Program - Maintain in FY1995 to support compliance with DOE Order 5632.6 and RLID 5632.1A to install and maintain locks, keys, and access control systems as requested by RL, WHC, KEH, and HEHF. 


\section{ELEMENT TASK DESCRIPTION}

\section{WORK STATEMENT -}

\section{REQUESTS WITHIN TARGET:}

This funding source supports the identified FTEs who are tasked with program management clerical support for the issuance and accountability of security keys as well as the installation and maintenance of locks, keys, and access control systems on the Hanford Site.

Activity Detailed Description

Matrix Support - Material Coordinator

Provide procurement support for Locksmi th materials.

\section{Activity Detailed Description}

Matrix Support - Hazardous Material Coordinator

Assume compliance with laws and regulations applicable to hazardous materials.

\section{REQUESTS ABOVE TARGET}

Activity Detailed Description

\begin{tabular}{|c|c|c|c|c|c|c|c|c|c|c|}
\hline & \multicolumn{2}{|c|}{ FY 1994 FYSF } & \multicolumn{2}{|r|}{ Delta } & \multicolumn{2}{|r|}{ FY 1995} & \multicolumn{2}{|r|}{ Delta } & \multicolumn{2}{|r|}{ FY 1996} \\
\hline & FTES & Dollars & FTES & Dollars & FTES & Dollars & FTES & Dollars & FTES & Dollars \\
\hline & $\left|\begin{array}{r}\cdots \\
\cdots \\
\cdots \\
\cdots \\
\cdots \\
\cdots\end{array}\right|$ & 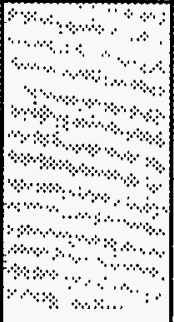 & कि & \% & के & Pro & \%ै. & Pि. & ?. & Pon \\
\hline Labor Cost & 7.0 & & -0.7 & -17.0 & 6.3 & 401.6 & 0.0 & 0.0 & 6.3 & 401.6 \\
\hline Non-Labor Cost & (3) & 297.2 & of & +140.2 & ?. & 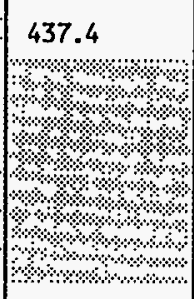 & मै. & 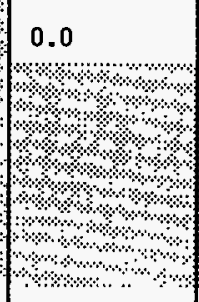 & मै. & 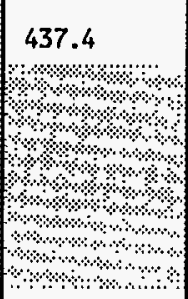 \\
\hline Labor Cost & 0.2 & 10.5 & 0.0 & -1.0 & 0.2 & 9.5 & 0.0 & 0.0 & 0.2 & 9.5 \\
\hline Non-Labor Cost & मे & म.3 & मै. & - & 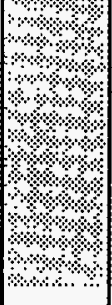 & 4.0 & 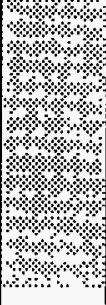 & 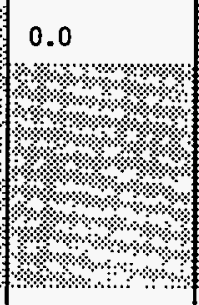 & 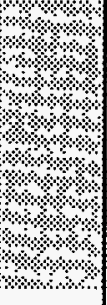 & 4.0 \\
\hline Labor cost & 0.4 & 28.4 & -0.2 & -18.9 & 0.2 & 9.5 & 0.0 & 0.0 & 0.2 & 9.5 \\
\hline Non-Labor Cost & खे & 12.0 & अे & -8.0 & ڤै. & 4.0 & २े.े & 0.0 & २ै. & 4.0 \\
\hline & 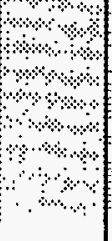 & क. & \%ै। & 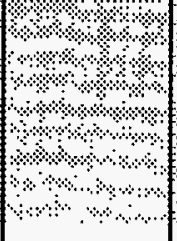 & & Pैo & $\begin{array}{l}\text { } \\
\% \\
\%\end{array}$ & 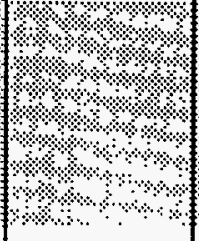 & \%ै. & moln \\
\hline $\begin{array}{l}\text { Labor Cost } \\
\text { Non-Labor Cost }\end{array}$ & क्ष & & $\$$ & & के & & & & & \\
\hline & 7.6 & 771.0 & -0.9 & +95.0 & 6.7 & 866.0 & 0.0 & 0.0 & 6.7 & 866.0 \\
\hline
\end{tabular}




\title{
LOCKSMITH: FY1995 RATE CALCULATION
}

\author{
FY1994 FY1995 \\ $771000 \quad 866000$ BUDGET \\ 175286 227294 LESS DIR MAT'L (\$200000 + MPR 11.3\% = \$222600)/PREMIUM LABOR (200 HRS @ $\$ 23.47=\$ 4694)$ \\ 595714 638706 REMAINING BUDGET • \\ $7161 \quad 7448$ EST DIRECT HOURS \\ $83 \% 19$ \\ 23.95 \\ अ85.76 EST RATE/DIRECT HOURS (HUB PROCESS CODE - LLR - LOCKSMITH LABOR) \\ 23.47 PREMIUM ADD: $\$ 23.47$ (FY1995 RATE $\$ 31.29 \times 1.75=\$ 54.76 . \$ 54.76-\$ 31.29=\$ 23.47$.) \\ 109.23 EST RATE/OVERTIME HOURS (HUB PROCESS CODE - LLJ - LOCKSMITH LABOR 1.5X)
}

5.0

1827

9135

$76.20 \%$

$\underline{6961}$

$\underline{200}$

7161

\author{
5.0 EST EFFICIENCY FACTOR - LOCKSMITH SERVICES \\ 1812 DIRECT CHARGING LABOR \\ 9060 AVG AVAILABLE REG HOURS/PERSON \\ 80.00\% EFFICIENCY FACTOR \\ 7248 EST DIRECT CHARGING REG HRS \\ $\underline{200}$ EST DIRECT CHARGING OVERTIME HOURS \\ 7448 TOTAL EST DIRECT CHARGING HOURS
}

NOTE: Department Overhead Rate applied in FY1995 is $42.0 \%$ of direct labor $(\$ 401.5 \bullet 42.0 \%=\$ 168.6)$.

The FY1994 budget contained a passback of $\$ 32.0$ and an Occupancy budget of $\$ 45.0$.

*The $\$ 42,992$ growth in budget (non - material) to be liquidated results in an increase of $\$ 2.57$ per hour to the liquidation rate. An increase in efficiency is expected - - (Budget request for training .2 FTE; misc meetings .2 FTE; inventory control .5 FTE; and stocking/cleaning Locksmith vehicles .1 FTE) - $1.0 \mathrm{FTE}=20.0 \%--$ Efficiency Factor $=80.0 \%$.

APPROVALS:

D. J. Haskins, Manager, Locksmith Services

C. W. Walton, Manager, Safeguards \& Security

L. C. Brandt, Manager, Program Support - Safeguards \& Security 


\begin{tabular}{|c|c|c|c|c|c|}
\hline \multirow{6}{*}{$\begin{array}{l}\text { Work } \\
\text { Breakdown } \\
\text { Structure } \\
\text { Dictionary }\end{array}$} & \multirow{6}{*}{\multicolumn{3}{|c|}{$\begin{array}{c}\text { Westinghouse Hanford Company } \\
\text { SAFEGUARDS AND SECURITY } \\
\text { Part I - Summary } \\
\text { (Dollars in } 000 \text { 's) }\end{array}$}} & \multirow{8}{*}{$\begin{array}{l}\text { FY1995 SSSP } \\
\text { Rev. \#0 }\end{array}$} & Funding Source: \\
\hline & & & & & G\&A \\
\hline & & & & & SHS \\
\hline & & & & & OST \\
\hline & & & & & DOH \\
\hline & & & & & MGT PRO \\
\hline \multirow{2}{*}{$\begin{array}{l}\text { Cost Account } \\
\text { IMDBON }\end{array}$} & \multirow{2}{*}{\multicolumn{3}{|c|}{$\begin{array}{l}\text { Cost Account Title: } \\
\text { VEHICLE SAFETY }\end{array}$}} & & POOL \\
\hline & & & & & DIRECT \\
\hline SMS WBS 6.6 .5 & \multirow{2}{*}{\multicolumn{3}{|c|}{ SMS Title: VEHICLE SAFETY }} & \multirow{2}{*}{\multicolumn{2}{|c|}{$\begin{array}{l}\text { Annualized Rate } \\
\text { (For Organizational Overhead } \\
\text { and Rated Service Pool Use Only) }\end{array}$}} \\
\hline CAM Revi ew/Approval M. B. JAEGER/376-3955 & & & & & \\
\hline \multicolumn{2}{|c|}{ SMS Program Manager Review/Approval C. W. WALTON/376-9927 } & & $\begin{array}{l}\text { Date } \\
\text { Date }\end{array}$ & FY 1994 Rate & FY 1995 Rate Request \\
\hline \multicolumn{2}{|c|}{ Financial Manager Review/Approval L. L. BRANDT/376-1756 } & & & & \\
\hline Responsible Analyst & RIPLEY/376-4015 & & $\frac{\text { Date }}{\text { Date }}$ & FY 1995 Target Rate & FY 1995 Approved Rate \\
\hline OSBRB Review/Approval & THOMAS/376-1730 & & Date & & \\
\hline (ా. & \multicolumn{2}{|c|}{ FY1994 } & \multicolumn{3}{|c|}{ FY1995 } \\
\hline FULL-TIME EQUIVALENTS (FTES) & Budget & $\begin{array}{r}\text { Fiscal Year Spending } \\
\text { Forecast (FYSF) } \\
\end{array}$ & Target & Request & $\begin{array}{l}\text { Approved } \\
\text { Basel ine }\end{array}$ \\
\hline - Organizational - Exempt & 4.0 & 4.0 & \multirow{5}{*}{ 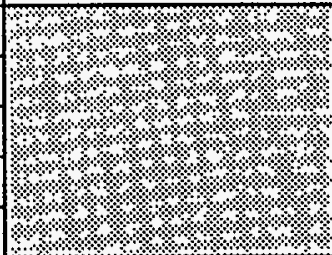 } & 4.0 & \multirow{5}{*}{ 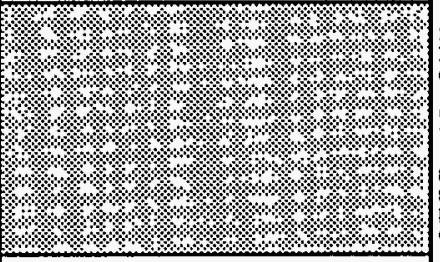 } \\
\hline - Organizational - Non Exempt & 0.5 & 0.5 & & 1.0 & \\
\hline \multicolumn{4}{|l|}{ - Organizational - Bargaining } & & \\
\hline Total Organizational FTEs & 4.5 & 4.5 & & 5.0 & \\
\hline Support FTEs & & & & & \\
\hline TOTAL FTES & 4.5 & 4.5 & & 5.0 & \\
\hline COST ELEMENTS & $1.1 .1 . \%$ & \% & 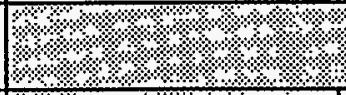 & \%. & (1.. \\
\hline - Labor - Regular & 343.4 & 250.0 & ४ & 292.3 & 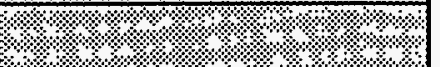 \\
\hline - Labor - Overtime & & & & & \% \\
\hline 0 Total Labor & 343.4 & 250.0 & $7 \%$ & 292.3 & \% \\
\hline 1 Materials & 25.0 & 10.0 & 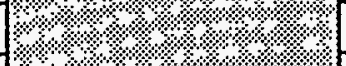 & 15.0 & \% \\
\hline 2 Purchased Services & 20.0 & 2.0 & 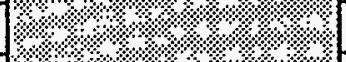 & 25.0 & 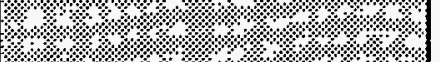 \\
\hline 3 other Hanford & 20.0 & 10.0 & +\%. & & \%... \\
\hline 4 Site Services & 30.0 & 7.0 & \%.$\% \% *$. & 1.7 & \% \%. \\
\hline 5 Internal Charges & & & ४ै * & & ४ै। \\
\hline 6 IRM Support & 22.0 & 1.0 & & 10.0 & ২ ২.। \\
\hline 7 overheads & & 3.0 & ४ै। & 122.8 & मे \\
\hline 8 Revenue & & & ४ै ४४ै। & & 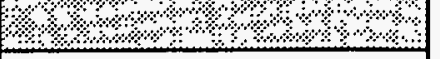 \\
\hline TOTAL DOLLARS & 460.4 & 283.0 & & 466.8 & \\
\hline
\end{tabular}




\begin{tabular}{|l|c|c|}
\hline Work Breakdown & Westinghouse Hanford Company & FY 1995 SSSP \\
Structure & Safeguards and security & Revision \#0 \\
Dictionary & Part II - Element Definition & \\
\hline
\end{tabular}

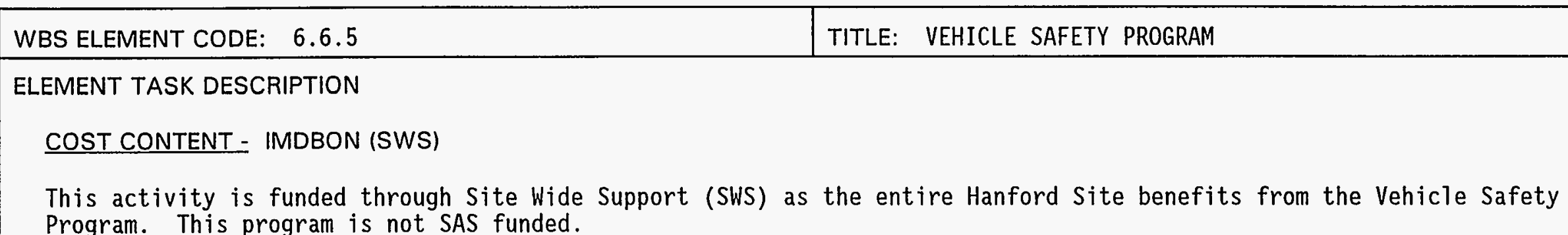

\section{TECHNICAL CONTENT -}

This program supports accident reduction and compliance requirements defined by DOE Order 3791.2A "Motor Vehicle Safety Program", DOE-RLIP 3791.2 "Motor Vehicle Safety Program", 29 CFR 1910.139 "Occupational Protection in Motor Vehicles", 49 CFR Chapter III, "Federal Highway Administration, Department of Transportation, and Title 46, Revised Code of Washington (RCW), "Motor Vehicles".

\section{OBJECTIVES -}

Development and implement a comprehensive site-wide motor vehicle/pedestrian safety program. The program will assign responsibility and accountability for all Westhinghouse Hanford Company (WHC) and sub-contractor motor

vehicle/pedestrian activities. It will encompass the use and operation of government vehicles and the use of roadways and pedestrian walkways on the Hanford Site.

\section{ASSUMPTIONS/CONSTRAINTS -}

None

\section{MILESTONES -}

None

\section{DELIVERABLES -}

Safety procedures and training programs to meet the intent of DOE Orders, Federal, State and 1ocal laws.

DOE Quarterly Government Vehicle Mileage Statistics.

DOE Monthly Government Vehicle Accident Satistics. 


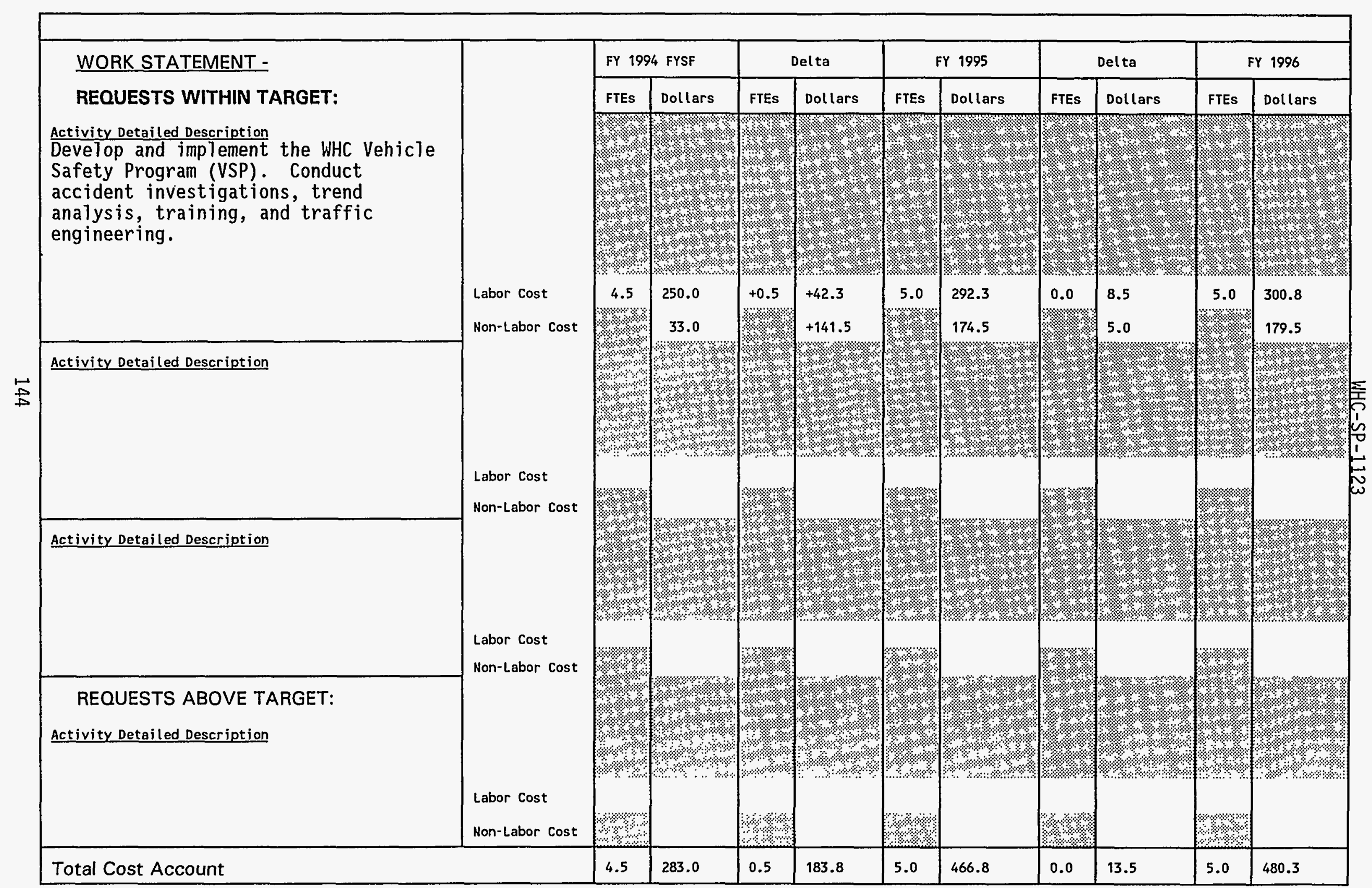




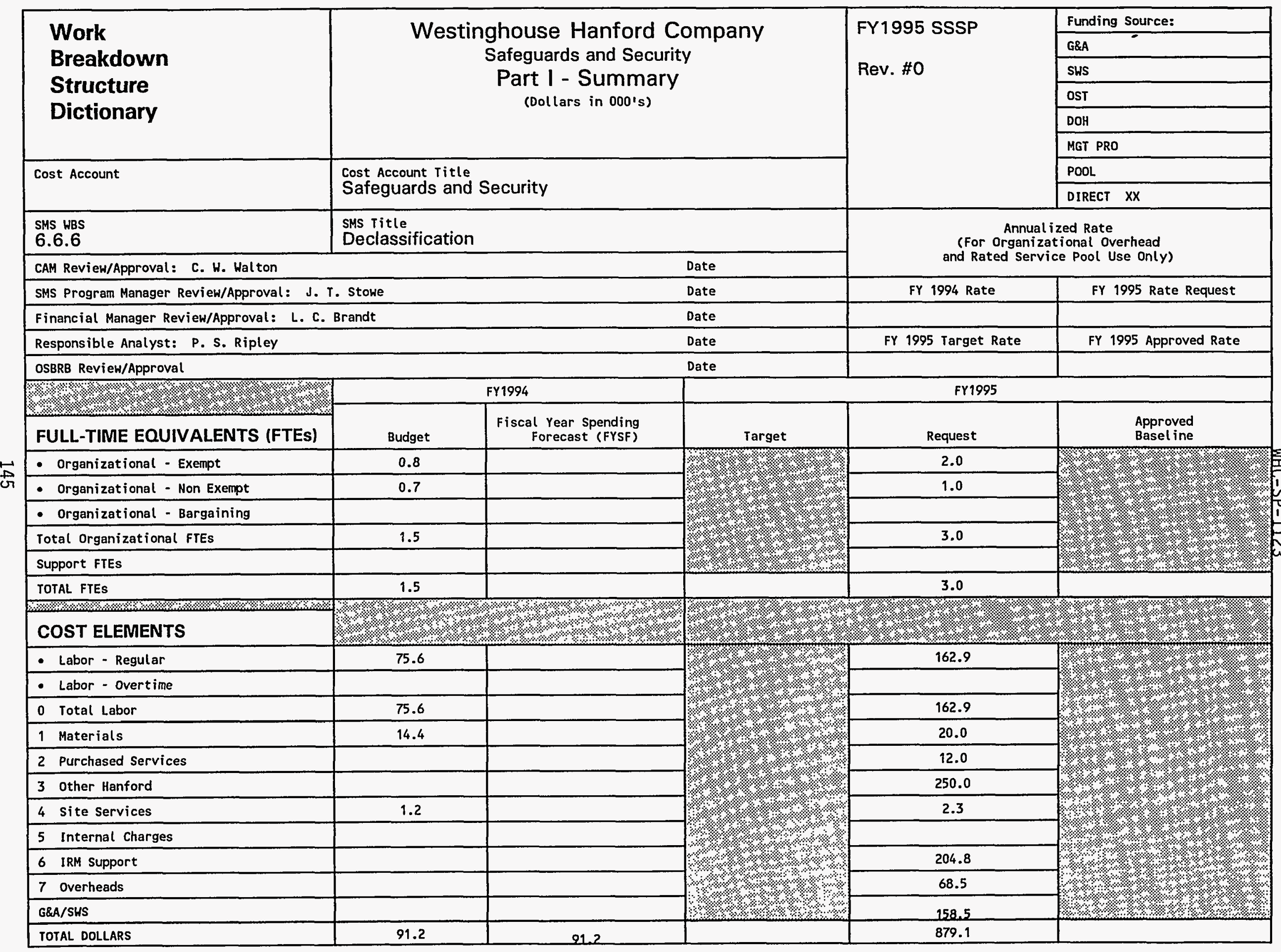




\section{Work Breakdown}

Structure

Dictionary

\section{Westinghouse Hanford Company}

Safeguards and Security

Part II - Element Definition
FY 1995 SSSP

Revision \#0

\begin{tabular}{|l|l|}
\hline WBS ELEMENT CODE: 6.6 .6 & TITLE: Declassification \\
\hline
\end{tabular}

ELEMENT TASK DESCRIPTION

COST CONTENT - EM-60 Facility Transition

TECHNICAL CONTENT -

Implement the provisions of the RL Plan for Declassification of Hanford Documents. This 1arge scale declassification review is in support of the Secretary's Openness Initiative.

\section{OBJECTIVES -}

Inventory and categorize approximately 60-65,000 classified documents controlled by WHC. Declassification will be conducted on a category priority established by RL and stakeholders. The goal is to prepare formerly classified documents for public release.

\section{ASSUMPTIONS/CONSTRAINTS -}

Funding for only 3.0 FTEs has been tentatively programmed. The number of FTEs is not sufficient to meet the milestone. The release of documents is contingent upon sufficient funding to inventory all historical documents and to fund a sufficient number of Authorized Derivative Declassifiers to complete this mission in five years.

\section{MILESTONES -}

Complete the inventory and develop a document data base that can be used to track documents through the declassification process. (4QFY95)

\section{DELIVERABLES :}

Computerized data base using the PNL developed system. Inventory of WHC controlled documents. 


\section{WORK STATEMENT -}

\section{REOUESTS WITHIN TARGET:}

Activity Detailed Description

Declassification Review of Hanford Classified Historical Documents

Activity Detailed Description

\section{Activity Detailed Description}

Activity Detailed Description

.

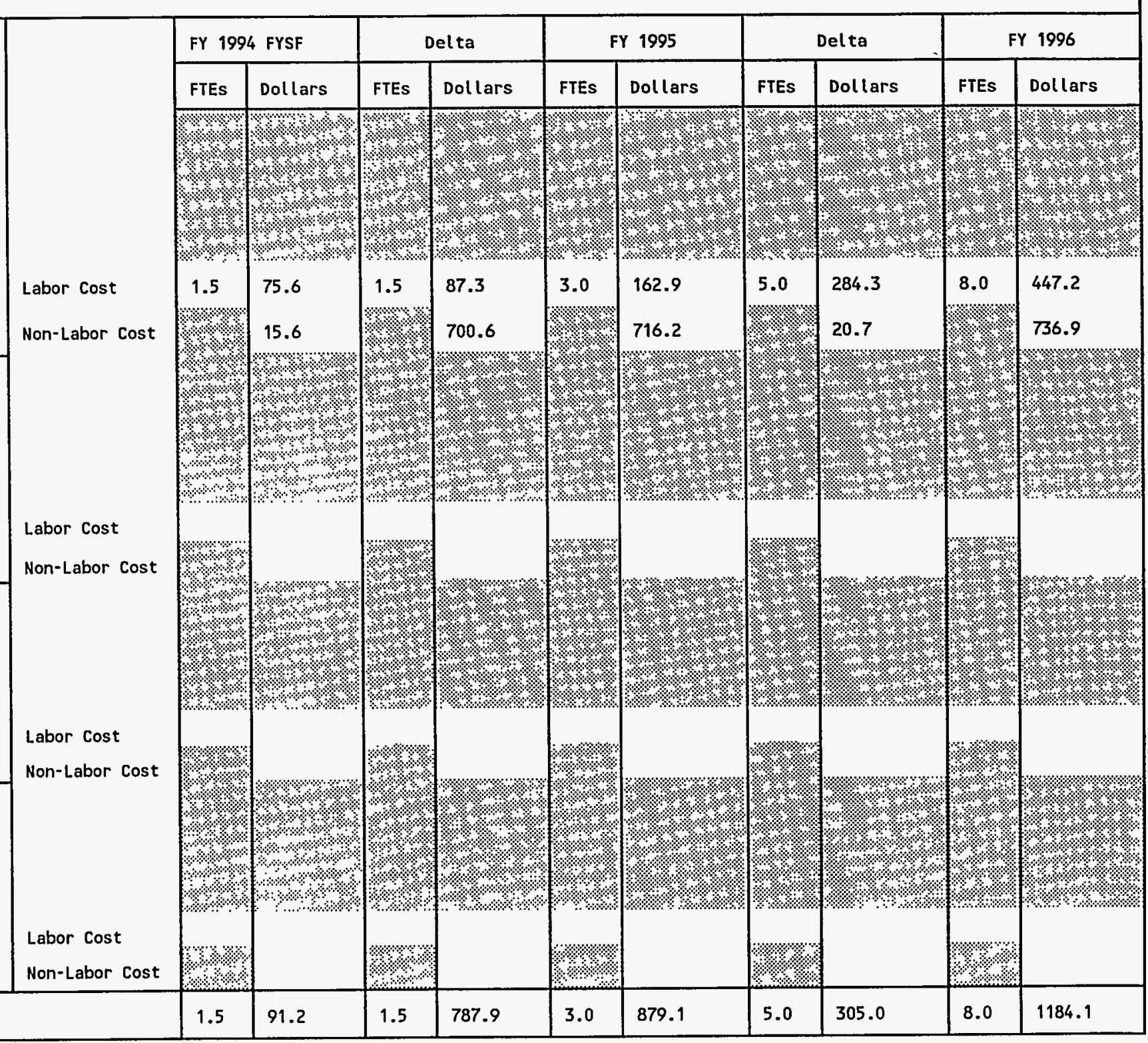




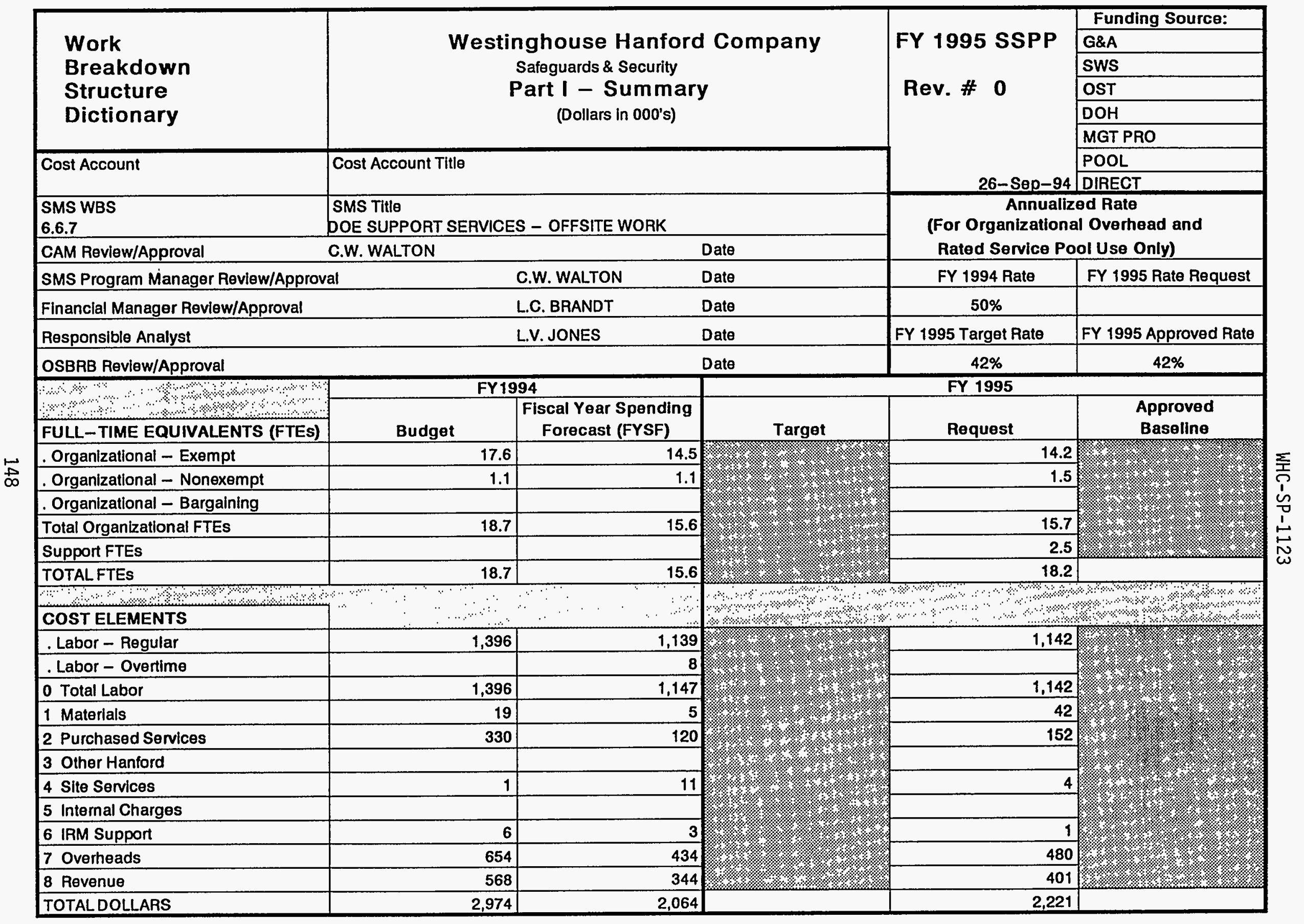




\begin{tabular}{|l|c|c|}
\hline \multicolumn{2}{|c|}{ CosT ACCOUNT } & \multicolumn{2}{|c|}{} \\
\hline $\begin{array}{l}\text { Work Breakdown } \\
\text { Structure }\end{array}$ & Westinghouse Hanford Company \\
Dictionary & Safeguards \& Securty & FY 1995 SSPP \\
\hline
\end{tabular}

\begin{tabular}{|l|l|}
\hline WBS ELEMENT CODE: 6.6 .7 & TITLE: OFF - SITE \\
\hline ELEMENT TASKDESCRIPTION &
\end{tabular}

COST CONTENT -

FUNDING IS PROVIDED BY OTHER DOE SITES (FIELD WORK PROPOSALS) AND COMMERICAL CONTRACTS (SPECIAL REQUEST AUTHORIZATIONS).

\section{TECHNICAL CONTENT -}

PROVIDES BOTH NONRESIDENT PERSONNEL SUPPORT AND HANFORD BASED SUPPORT TO OFFSITE CUSTOMERS. THIS SUPPORT COVERS VARIOUS VARIOUS SUBJECTS IN THE FIELD OF SAFEGUARDS IN THE FIELD OF SAFEGUARDS AND SECURITY.

OBJECTIVES -

ASSIST GOVERNMENT AGENCIES AND CONTRACTING ORGANIZATIONS, AS APPROVED BY DOE-RL, IN ESTABLISHING UNIFORM, COST EFFECTIVE SAFEGUARDS AND SECURITY PROGRAMS.

\section{ASSUMPTIONS/CONSTRAINTS -}

WORKSCOPE FOR THE FIELD WORK PROPOSALS ARE DETERMINED BY DOE-HQ. THE WORK STATEMENT DETAILS THE WORK BEING PROPOSED. ASSUMING NO CHANGE FROM FY 93 WORK SCOPE FOR OTHER OFFSITE WORK.

MILESTONES -

DELIVERABLES - 


\section{\begin{tabular}{|l|l}
\hline Cost Account & Part II - Element Definition (continued) \\
\hline
\end{tabular}}

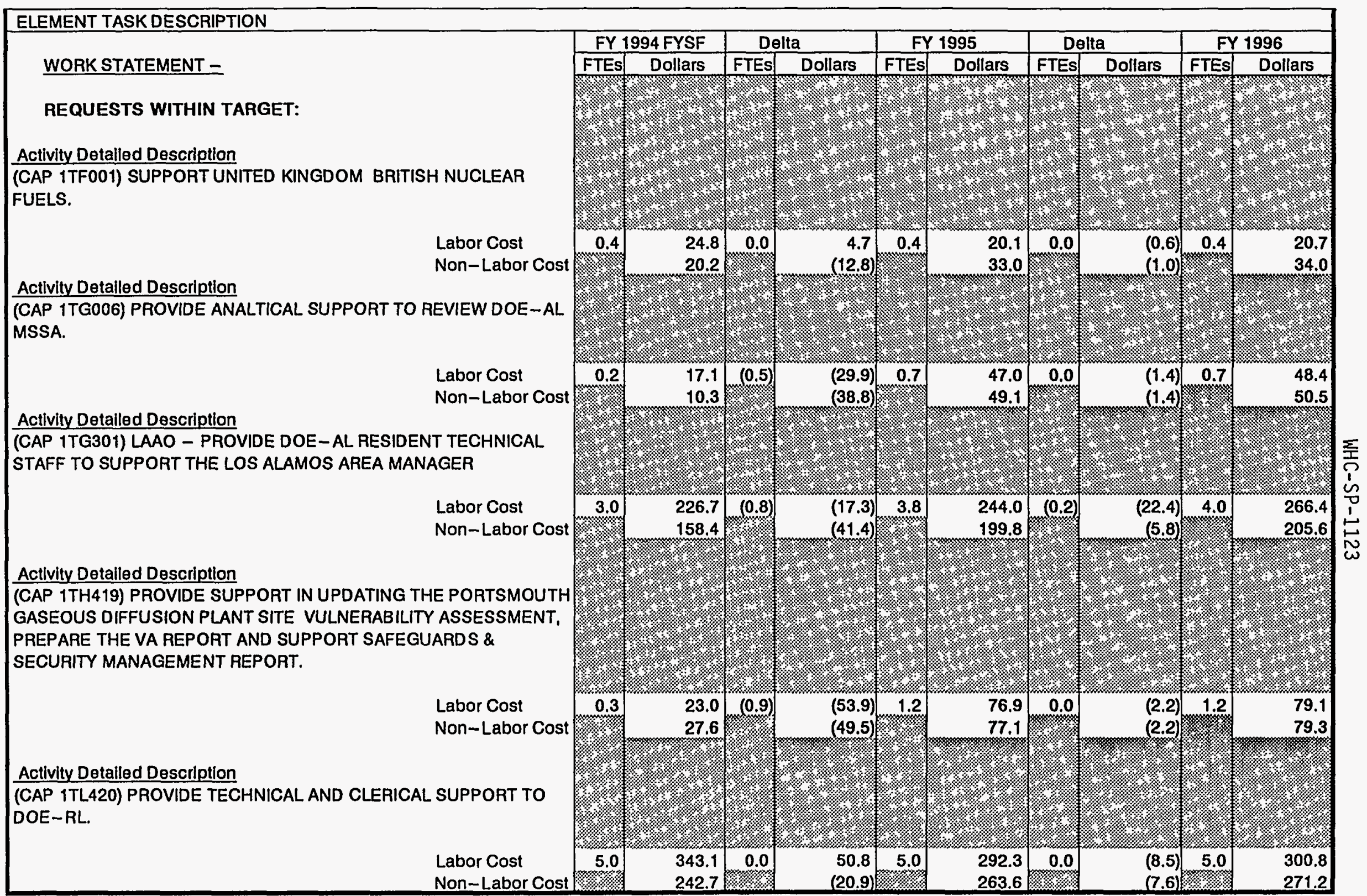




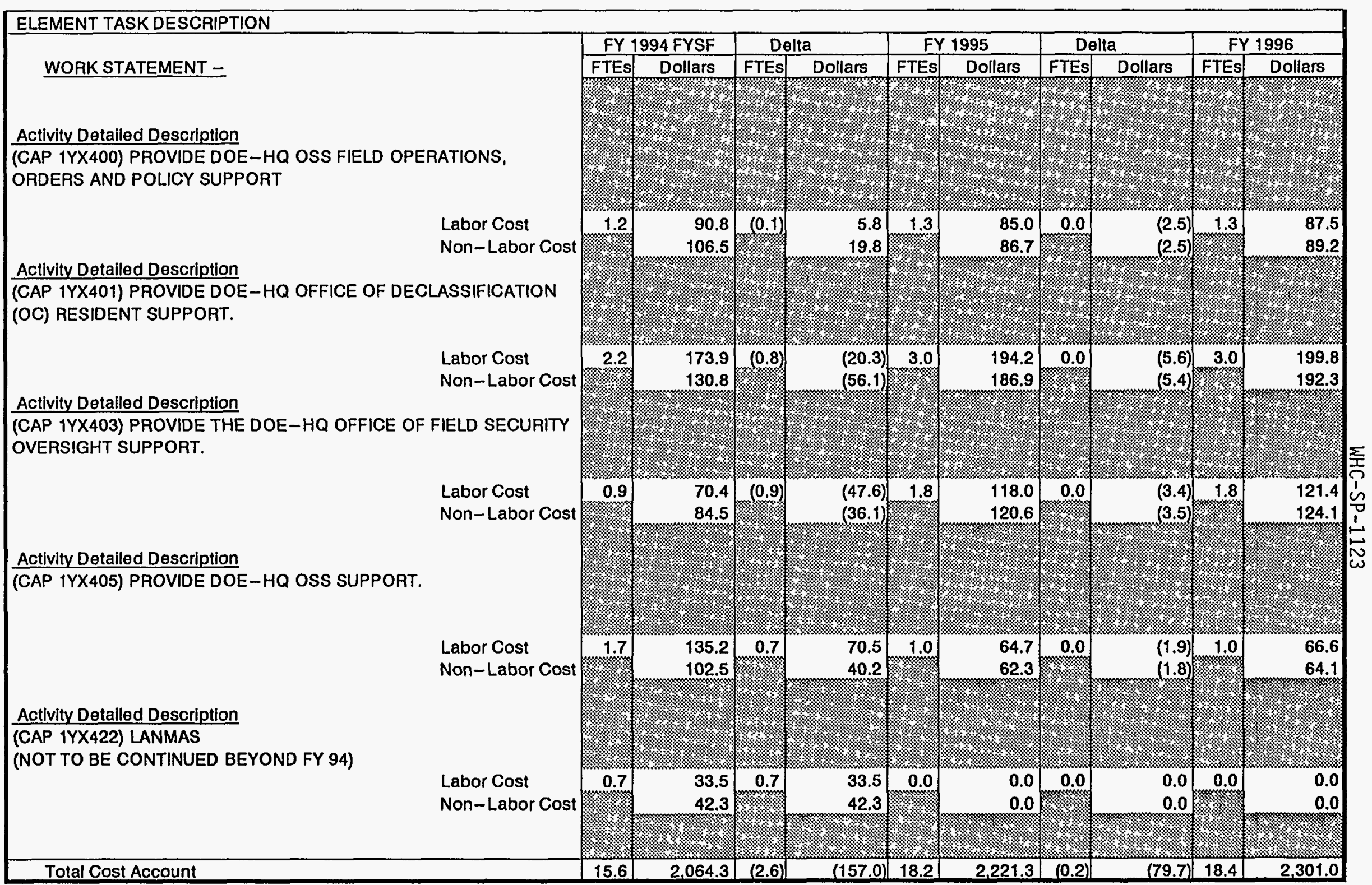




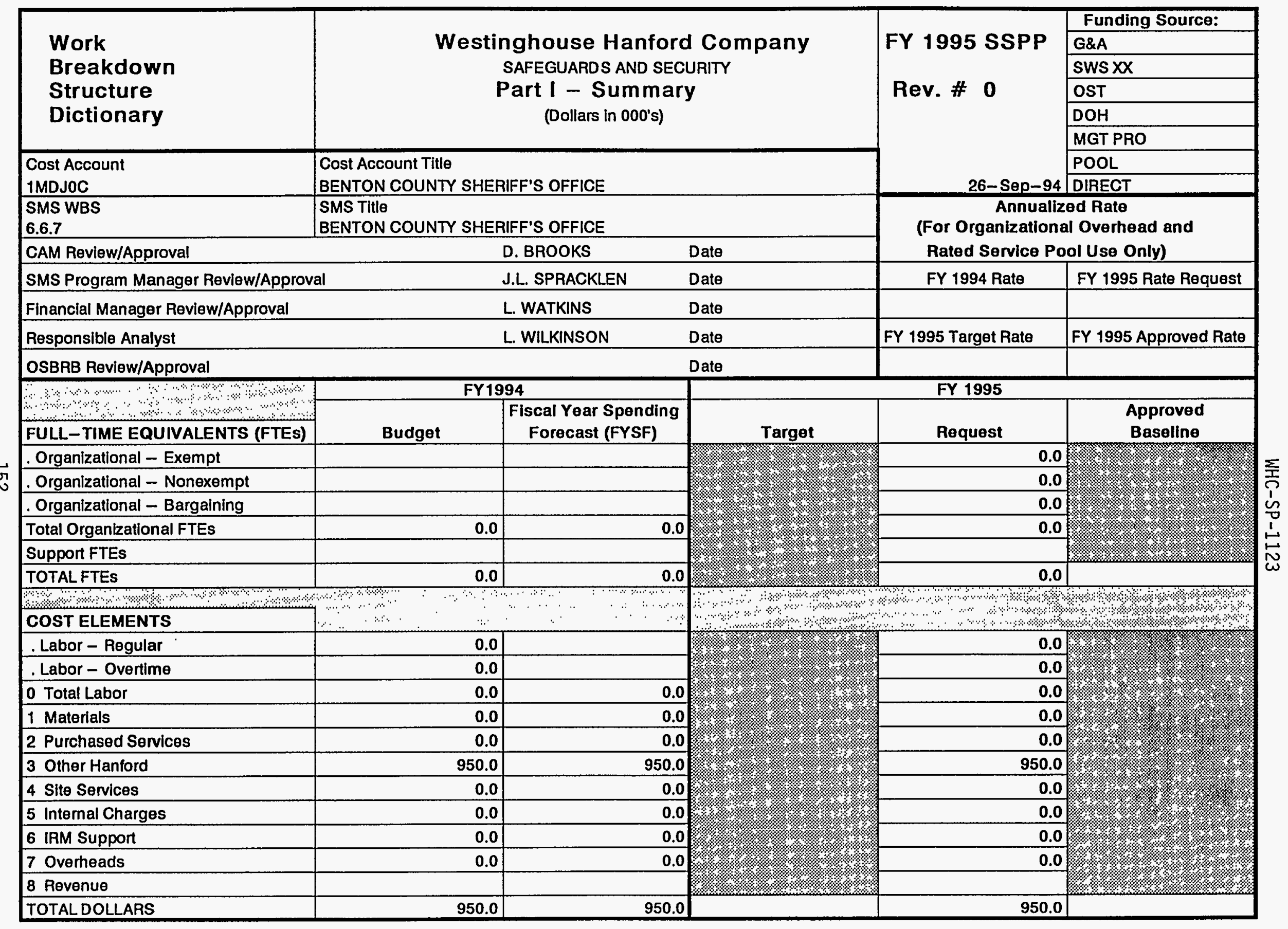




\begin{tabular}{|c|c|c|c|c|c|}
\hline \multirow{6}{*}{$\begin{array}{l}\text { Work } \\
\text { Breakdown } \\
\text { Structure } \\
\text { Dictionary }\end{array}$} & \multirow{6}{*}{\multicolumn{3}{|c|}{$\begin{array}{c}\text { Westinghouse Hanford Company } \\
\text { Safeguards \& Security } \\
\text { Part I - Summary } \\
\text { (Dollars in 000's) }\end{array}$}} & \multirow{8}{*}{$\begin{array}{l}\text { FY } 1995 \text { SSPP } \\
\text { Rev. \# } 0\end{array}$} & \multirow{3}{*}{\begin{tabular}{|l}
\multicolumn{2}{|c}{ Funding Source: } \\
G\&A \\
SWS \\
\end{tabular}} \\
\hline & & & & & \\
\hline & & & & & \\
\hline & & & & & OST \\
\hline & & & & & DOH $\quad X$ \\
\hline & & & & & MGT PRO \\
\hline Cost Account & Cost Account Title & & & & $\mathrm{POOL}$ \\
\hline 1J3B & Safeguards \& Securlty De & epartment Overhead & & & $\longdiv { D I R E C T }$ \\
\hline $\begin{array}{l}\text { SMS WBS } \\
6.6 .8\end{array}$ & $\begin{array}{l}\text { SMS Titlo } \\
\text { SAFEGUARD \& SECURIT }\end{array}$ & TY DEPARTMENT OVERHE & $E A D$ & $\begin{array}{r}\text { Annualize } \\
\text { (For Organizational }\end{array}$ & $\begin{array}{l}\text { al Rate } \\
\text { al Overhead and }\end{array}$ \\
\hline CAM Review/Approval & & C.W. WALTON & Date & Rated Service Poc & ol Use Only) \\
\hline SMS Program Manager Reviow/Approva & & C.W. WALTON & Date & FY 1994 Rate & FY 1995 Rate Request \\
\hline Financial Manager Review/Approval & & L.C. BRANDT & Date & $50 \%$ & $42 \%$ \\
\hline Responsible Analyst & & L.V. JONES & Date & FY 1995 Target Rate & FY 1995 Approved Rate \\
\hline OSBRB Review/Approval & & & Date & $42 \%$ & \\
\hline 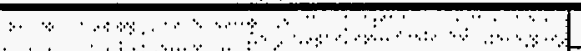 & FY19 & 994 & & FY 1995 & \\
\hline 更 & & Fiscal Year Spending & & & Approved \\
\hline FULL-TIME EQUIVALENTS (FTES) & Budget & Forecast (FYSF) & Target & Request & Baseline \\
\hline . Organizational - Exempt & 20.3 & 19.8 & \% & 12 & \\
\hline . Organizational - Nonexempt & 9 & 8.8 & & 5.5 & \\
\hline . Organlzational - Bargaining & 0 & 0.5 & & 0 & 8 \\
\hline Total Organizational FTEs & 29.3 & 29.1 & & 17.5 & (4) \\
\hline Support FTEs & 1.8 & 2.1 & 1 & 1.6 & (1. \\
\hline TOTAL FTES & 31.1 & 31.2 & 1 & 19.1 & \\
\hline व $\cdots \cdots$ & $\cdots \cdots$ & $\cdots \quad \cdots$ & 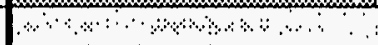 & ? & 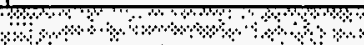 \\
\hline COST ELEMENTS & & & « - & 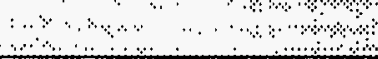 & ४४ \\
\hline . Labor - Regular & 1,861 & 1,789 & \% & 1,068 & ২ি. \\
\hline Labor - Overtime & 1 & 26 & H. & 0 & : \\
\hline 0 Total Labor & 1,862 & 1,815 & (4). & 1,068 & \\
\hline 1 Materials & 662 & 533 & H4\% & 517 & \\
\hline 2 Purchased Services & 1,047 & 402 & 1: & 879 & s s \\
\hline 3 Other Hanford & 230 & 221 & 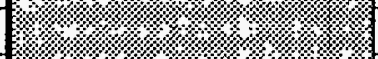 & 443 & \\
\hline 4 Site Services & 3,330 & 3,411 & \% & 3,587 & \\
\hline 5 Internal Charges & 1,750 & 1,606 & & 1,636 & \\
\hline 6 IRM Support & 948 & 961 & $1 \%$ & 980 & \\
\hline 7 Overheads & 65 & 33 & 14: & 59 & 18 \\
\hline 8 Revenue & & & 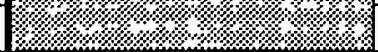 & & $1 \%$ \\
\hline TOTALDOLLARS & 9,894 & 8,982 & & 9,169 & \\
\hline
\end{tabular}




\begin{tabular}{|c|c|}
\hline WBS ELEMENT CODE: $\quad \mathbf{6 . 6 . 8}$ & TITLE: Safeguards \& Security Department Overhead \\
\hline
\end{tabular}

COST CONTENT -

Department overhead.

TECHNICAL CONTENT -

Manage the Safeguards and Security organization, meet all administrative requests necessary to function as a Westinghouse Hanford department.

Ensure the Safeguards and Security is operating in a safe, cost effective environmentally sound manner.

ASSUMPTIONS/CONSTRAINTS -

Assuming 17.5 SAS and 1.6 support FTEs are required to support overhead activities.

MILESTONES -

DELIVERABLES - 


\section{ELEMENT TASKDESCRIPTION}

WORK STATEMENT -

REQUESTS WITHIN TARGET:

Activity Detailed Description

EXEMPT MANAGEMENT \& ADMINISTRATIVE STAFF SUPPORT INCLUDES: STAFFING MEETINGS, BUILDING MAINTENANCE, TOTAL QUALITY, SAFETY COUNCIL, ECCEL, COMPUTER SECURITY AND INVENTORY.

Activity Detailed Description NON-EXEMPT ADMINISTRATIVE STAFF SUPPORT AND BARGIANING UNIT

Activity Detalled Description

SUPPORT LABOR FROM OTHER ORGANIZATIONS

Labor Cost Non-Labor Cost

Activity Detalled Description

OVERTIME

Activity Detailed Description MATERIAL

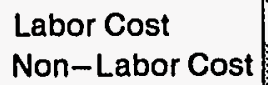

\begin{tabular}{|c|c|c|c|c|c|c|c|c|c|}
\hline FY 1 & 94 FYSF & De & & $F Y$ & 1995 & $\mathrm{De}$ & & FY & 1996 \\
\hline FTES & Dollars & FTES & Dollars & FTES & Dollars & FTES & Dollars & FTES & Dollars \\
\hline 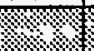 & ২. & \% & ₹. & 2 & & & ४ః & & \\
\hline
\end{tabular}
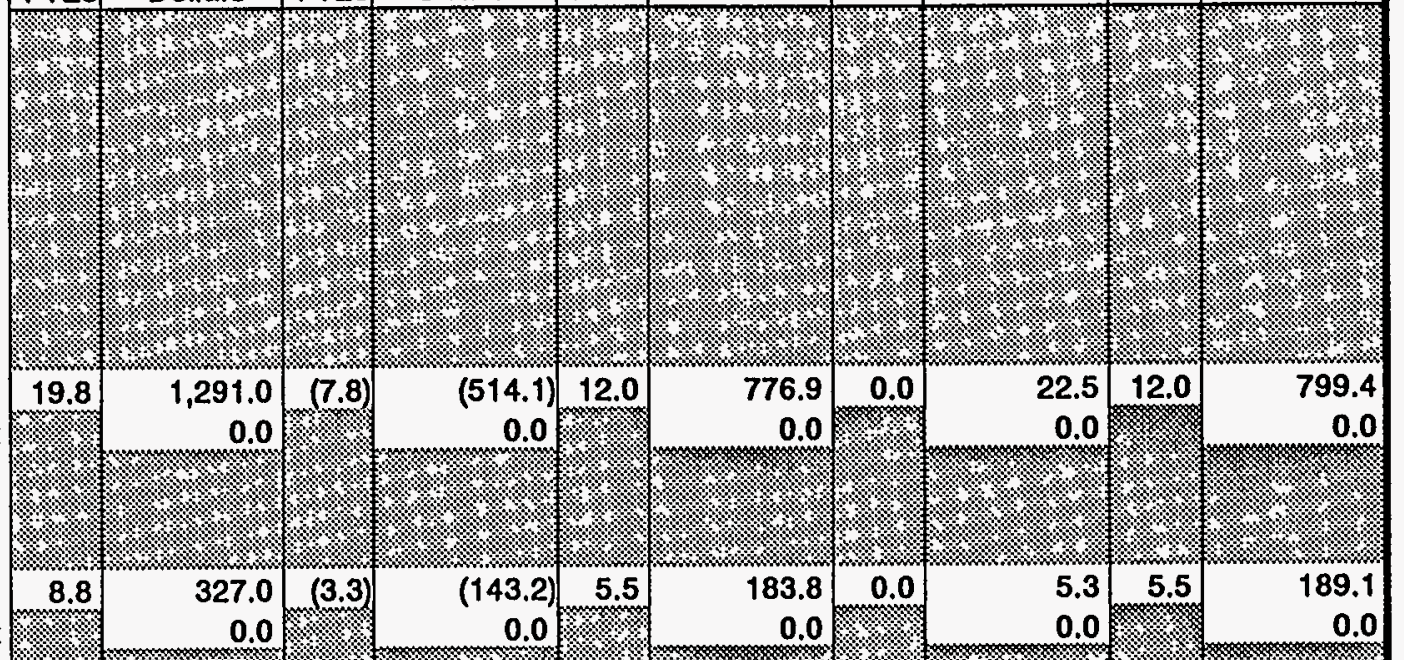

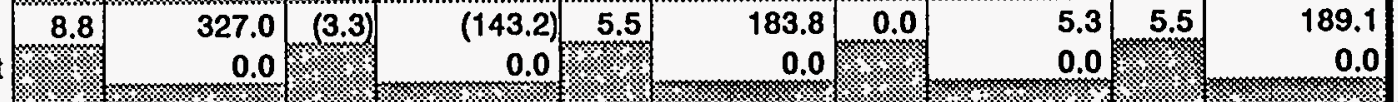

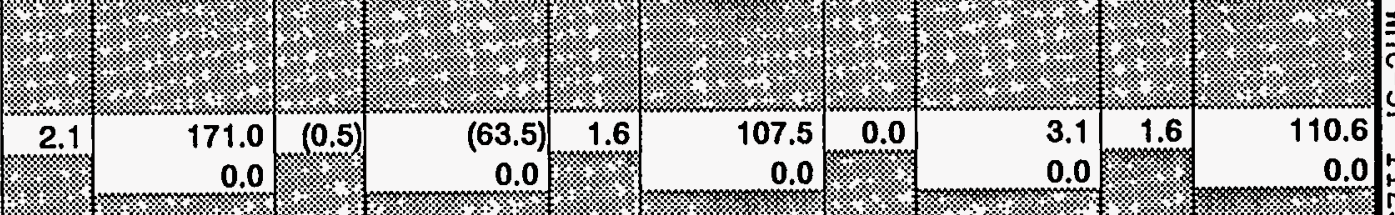

Labor Cost Non-Labor Cost Labor Cost
Non-Labor Cost . $.1 .1 .1 .1 .1 \%$.

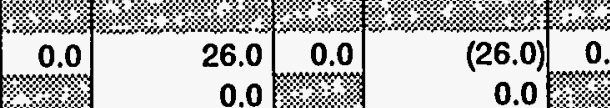
0.0 0.0 .

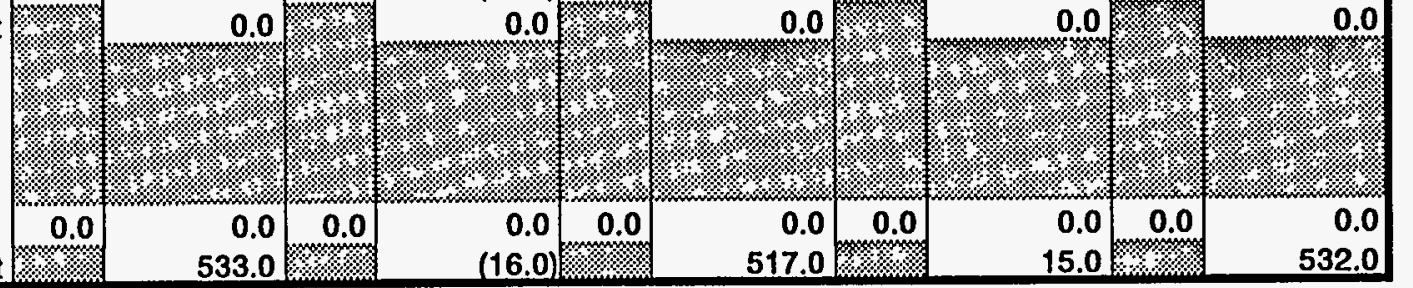

Labor Cost Non-Labor Cost 
Activity Detalled Description

PUACHASE SERVICES

THE INCREASE IS DUE TO TRAINING (CTA), SAC MOVE.

TRAINING INCLUDES; SAFETY, CRITICALITY, BLOOD BORNE

PATHOGEN, HAZMAT, ECT...

Activity Detalled Description

OTHER CONTRACTORS

PNL 116K, HEHF 16K, AND KAISER 301K

ALL OF THE INCREASE IS IN KAISER AND DUE TO UPGRADES OF EXISTING FACILITIES TO CONSOLIDATE SAS PERSONNEL

Actlvity Detailed Description

Labor Cost

SITE SERVICES

THE INCREASE IS DUE TO CONSOLIDATION OF SAS SITE

SERVICES COST (FLEET, BUS OPS, OCCUPANCY), WHICH WERE PREVIOUSLY PAID FROM DIRECT, CSP AND G\&A.

Labor Cost

\begin{tabular}{|c|c|c|c|c|c|c|c|c|c|}
\hline \multicolumn{2}{|c|}{ FY 1994 FYSF } & \multicolumn{2}{|c|}{ Delta } & \multicolumn{2}{|c|}{ FY 1995} & \multicolumn{2}{|c|}{ Delta } & \multicolumn{2}{|c|}{ FY 1996} \\
\hline FTES & Dollars & FTEs & Dollars & FTES & Dollars & FTEs & Dollars & FTES & Dollars \\
\hline
\end{tabular}

Non-Labor Cost

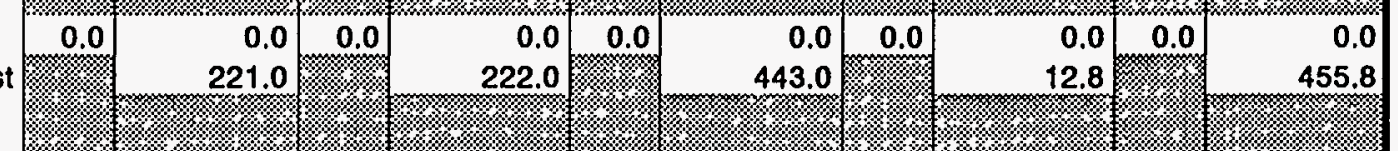

INTERNAL CHARGES

MANGEMENT PRORATION AND DOSIMETRY.

Activity Detailed Description

IRM SUPPORT

EUC NTA AND TELEPHONE BUDGET

Activity Detailed Description

OVERHEAD

$$
\begin{aligned}
& \text { Labor Cost } \\
& \text { Non-Labor Cost }
\end{aligned}
$$

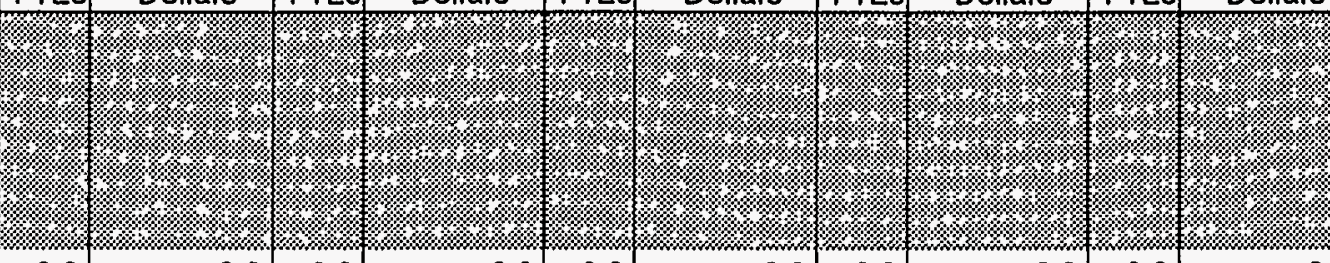

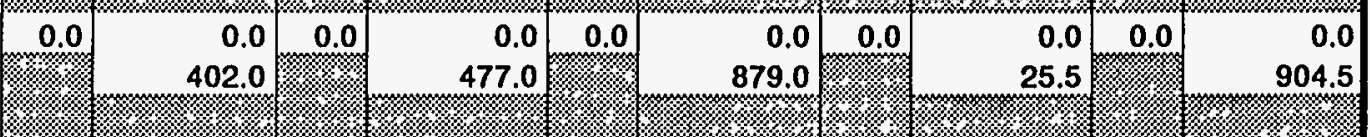

Labor Cost

Non-Labor Cost

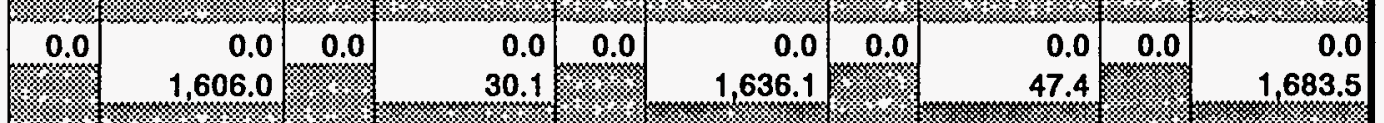

Labor Cost

Non-Labor Cost

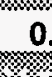

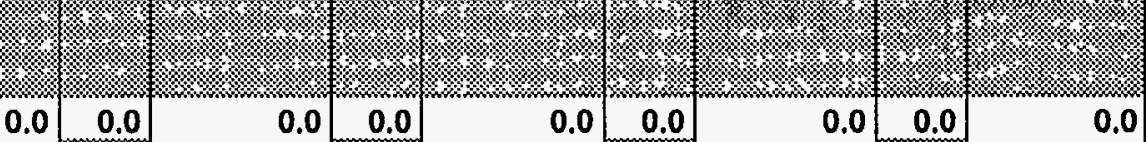

$\begin{array}{rr}961.0 & 0.0 \\ 19.0 & 0.0\end{array} \quad \begin{array}{r}0.0 \\ 980.0\end{array} \quad \begin{aligned} & 0.0 \\ & 28.4\end{aligned}$

Total Cost Account

Labor Cost

Non-Labor Cost 


\begin{tabular}{|c|c|c|c|c|c|c|c|c|c|c|c|c|c|c|c|c|c|c|}
\hline $\begin{array}{l}\text { Work } \\
\text { Breakdown } \\
\text { Structure } \\
\text { Dictionary }\end{array}$ & & \multicolumn{14}{|c|}{$\begin{array}{c}\text { Westinghouse Hanford Company } \\
\text { (insert responsible organization title here) } \\
\text { Part III - Liquidation Base Analysis } \\
\text { OR ORGANIZATIONAL OVERHEAD ONLY }\end{array}$} & \multicolumn{3}{|c|}{ Revision \# 0} \\
\hline $\begin{array}{l}\text { Cost Account } \\
1 \mathrm{~J} 3 \mathrm{~B} 00\end{array}$ & & \multicolumn{17}{|c|}{$\begin{array}{l}\text { Cost Account Title } \\
\text { SAS DEPARTMENT OVERHEAD }\end{array}$} \\
\hline & & $1 \% 1 \% 109 \%$ & 18 & & 8 & 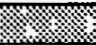 & $5 \times$ & 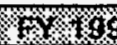 & (f) & 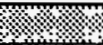 & 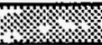 & & 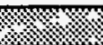 & $0 \%$ & (1) (15) & $x(6)$ & (c) & (8) \\
\hline DIRECT STAFF* & & $\frac{10070 \%}{4}$ & OCT & Nov & DEC & JAN & FEB & MAA & APR & MAY & JUN & JUL & AUG & SEP & $\begin{array}{l}\text { AVG. } \\
\text { DIRECT } \\
\text { STAFF }\end{array}$ & $\begin{array}{c}\text { AVG. } \\
\text { LABOR } \\
\text { RATE } \\
\end{array}$ & $\begin{array}{c}\text { REALIZATION } \\
\text { HOURS }\end{array}$ & $\begin{array}{l}\text { DIRECT } \\
\text { LABOR } \\
(\$ 000)\end{array}$ \\
\hline EXEMPT & & । & 159.0 & 159.0 & 159.0 & 159.0 & 159.0 & 159.0 & 155.0 & 155.0 & 155.0 & 155.0 & 155.0 & 155.0 & 157.0 & 35.72 & 1812 & 10,162 \\
\hline NONEX / PT / TEMP & & & 43.5 & 43.5 & 43.5 & 43.5 & 43.5 & 43.5 & 42.5 & 42.5 & 42.5 & 42.5 & 42.5 & 42.5 & 43.0 & 18.44 & 1812 & 1,437 \\
\hline BU PATROL & & & 145.0 & 145.0 & 145.0 & 145.0 & 145.0 & 145.0 & 145.0 & 145.0 & 145.0 & 145.0 & 145.0 & 145.0 & 145.0 & 23.97 & 1812 & 6,298 \\
\hline BU MAINT. & & & 18.0 & 18.0 & 18.0 & 18.0 & 18.0 & 18.0 & 18.0 & 18.0 & 18.0 & 18.0 & 18.0 & 18.0 & 18.0 & 32.06 & 1812 & 1,046 \\
\hline OVERTIME FACTOR & $\%$ & & & (2) & 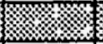 & (1) & 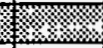 & r) & 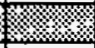 & 1 & & 18: & + & 18 & & 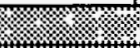 & 18 & 3,446 \\
\hline DIRECT LABOR BASE & & 1; & 365.5 & 365.5 & 365.5 & 365.5 & 365.5 & 365.5 & 360.5 & 360.5 & 360.5 & 360.5 & 360.5 & 360.5 & 363.0 & & 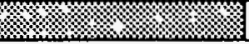 & 22,388 \\
\hline
\end{tabular}

\begin{tabular}{|c|c|}
\hline ORG OVHD COST & 8,982 \\
\hline DIRECT LABOA BASE & 18,850 \\
\hline RATE (COST/BASE) & $47.6 \%$
\end{tabular}
@ 7 Exempt liquidate at $41 \%$ no matter what rate the rest of SAS liqiudate.
*Direct staff is staff that charges labor to charge codes on which organizational overhead is applied.




\begin{tabular}{|c|c|c|}
\hline \multicolumn{3}{|c|}{$\begin{array}{l}\text { West inghouse Hanford Company } \\
\text { MILESTONE DESCRIPTION SHEET }\end{array}$} \\
\hline \multicolumn{2}{|l|}{$\begin{array}{l}\text { Title: } \\
\text { FY } 1995 \text { Hanford SSSP }\end{array}$} & $\begin{array}{l}\text { Date Prepared: } \\
08 / 09 / 94\end{array}$ \\
\hline \multicolumn{2}{|l|}{ Assigned To: C. J. Ude11 } & CIN: \\
\hline \multicolumn{2}{|l|}{ WBS Designator: $6 \cdot 6 \cdot 3.4$} & Due Date: $9 / 30 / 95$ \\
\hline \multicolumn{2}{|l|}{ Control Number: SSP-95-01 } & Revision: \\
\hline \begin{tabular}{l|l} 
Milestone Type: & \multicolumn{1}{c}{ Division: } \\
$\square$ DOE-HQ & $\square$ State \\
DOE-RL & $\square$ Federal \\
$\square$ CNTR & DOE \\
& $\square$ RCRA \\
& $\square$ TPA\# \\
\end{tabular} & $\begin{array}{l}\text { DELIVERABLE: } \\
\text { Report } \\
\square \text { Letter } \\
\square \text { Drawings } \\
\square \text { Other } \\
\text { (specify) }\end{array}$ & $\begin{array}{ll} & \text { ADDRESS TO: } \\
\square & \text { DOE-HQ } \\
\text { DOE-RL } \\
\square \text { Other } \\
\text { (specify) }\end{array}$ \\
\hline \multicolumn{3}{|l|}{ Milestone Description } \\
\hline \multicolumn{3}{|c|}{$\begin{array}{l}\text { Submit a draft update of the } 1995 \text { Hanford SSSP to DOE-RL for review and } \\
\text { comment. }\end{array}$} \\
\hline \multicolumn{3}{|c|}{ Description of what constitutes completion of this milestone: } \\
\hline \multicolumn{3}{|l|}{ Provide draft report to DOE-RL. } \\
\hline $\begin{array}{l}\text { Cost Account Manager } \\
\text { C. W. Walton }\end{array}$ & $\begin{array}{l}\text { Program/Project } \\
\text { C. W. Walton }\end{array}$ & nager \\
\hline $\begin{array}{l}\text { Program Element Manager } \\
\text { C. J. Udell }\end{array}$ & $\begin{array}{l}\text { DOE Monitor } \\
\text { J.L. Spracklen }\end{array}$ & Date \\
\hline
\end{tabular}




\begin{tabular}{|c|c|c|}
\hline \multicolumn{2}{|l|}{$\begin{array}{l}\text { Title: } \\
\text { Reduce Overtime Training by } 15 \%\end{array}$} & $\begin{array}{l}\text { Date Prepared: } \\
\text { July 28, } 1994\end{array}$ \\
\hline \multicolumn{2}{|l|}{ Assigned To: B. W. Cameron } & CIN: \\
\hline \multicolumn{2}{|l|}{ WBS Designator: 6.6 .3 .1} & Due Date: $9 / 30 / 95$ \\
\hline \multicolumn{2}{|l|}{ Control Number: SSP-95-02 } & Revision: \\
\hline 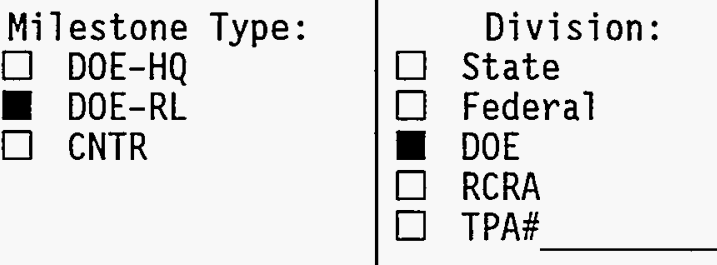 & $\begin{array}{l}\text { DELIVERABLE: } \\
\text { Report } \\
\square \text { Letter } \\
\square \text { Drawings } \\
\square \text { Other } \\
\text { (specify) }\end{array}$ & $\begin{array}{l}\text { ADDRESS TO: } \\
\square \text { DOE-HQ } \\
\text { DOE-RL } \\
\square \text { Other } \\
\text { (specify) }\end{array}$ \\
\hline \multicolumn{3}{|l|}{ Milestone Description } \\
\hline \multicolumn{3}{|c|}{$\begin{array}{l}\text { Through computer based training and field training officers, reduce the } \\
\text { budgeted overtime training/contingency exercise hours by } 15 \% \text {. }\end{array}$} \\
\hline \multicolumn{3}{|c|}{ Description of what constitutes completion of this milestone: } \\
\hline \multicolumn{3}{|l|}{ Quarterly Total Quality Reports. } \\
\hline $\begin{array}{l}\text { Cost Account Manager } \\
\text { C. W. Walton }\end{array}$ & $\begin{array}{l}\text { Program/Project } \\
\text { C. W. Walton }\end{array}$ & lager \\
\hline $\begin{array}{l}\text { Program Element Manager } \\
\text { V. G. Heiman }\end{array}$ & $\begin{array}{l}\text { DOE Monitor } \\
\text { J. L. Spracklen }\end{array}$ & Date \\
\hline
\end{tabular}




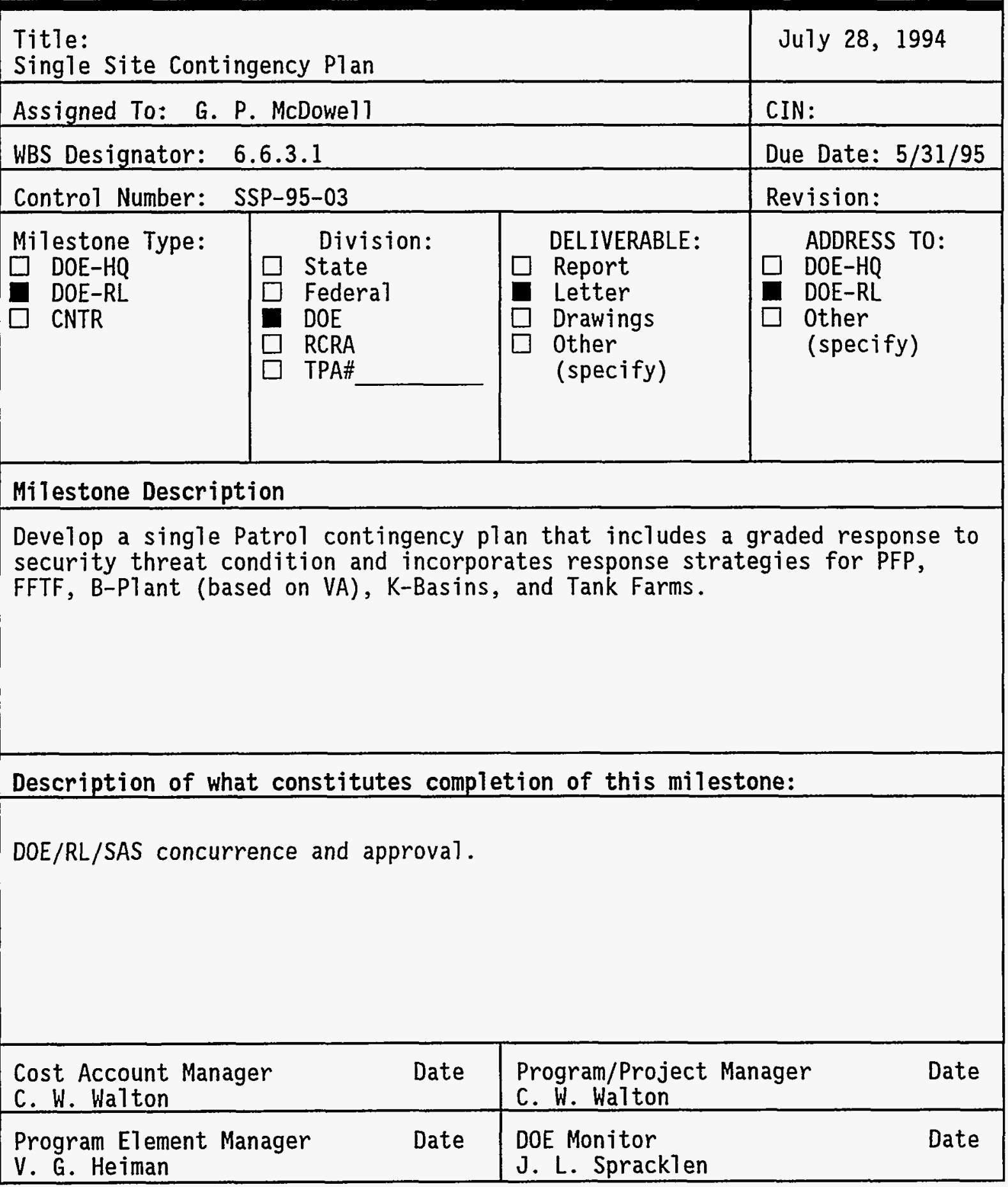




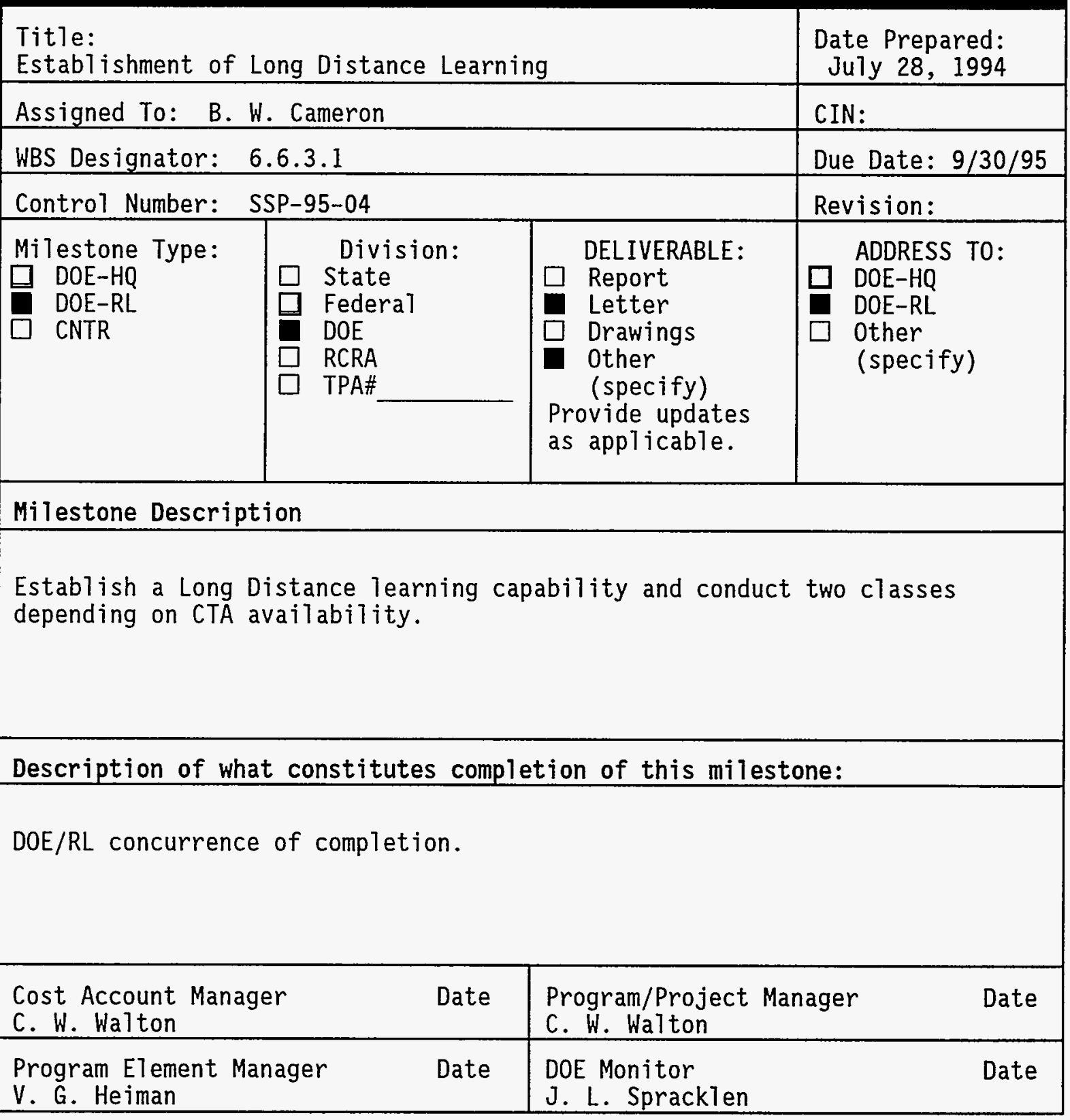


Westinghouse Hanford Company MILESTONE DESCRIPTION SHEET

\begin{tabular}{|c|c|c|c|}
\hline \multicolumn{2}{|l|}{$\begin{array}{l}\text { TitTe: } \\
\text { FY } 1994 \text { Hanford SSSP }\end{array}$} & $\begin{array}{l}\text { Date } \\
09 / 15\end{array}$ & \\
\hline \multicolumn{2}{|l|}{ Assigned To: C. J. Ude11 } & CIN: & \\
\hline \multicolumn{2}{|l|}{ WBS Designator: 6.6 .3 .4} & $\begin{array}{l}\text { Due } \\
11 / 30\end{array}$ & \\
\hline \multicolumn{2}{|l|}{ Control Number: SSP-95-05 } & Revis & \\
\hline \begin{tabular}{l|l} 
Milestone Type: & \multicolumn{1}{c}{ Division: } \\
$\square$ DOE-HQ & $\square$ State \\
DOE-RL & $\square$ Federal \\
$\square$ CNTR & DOE \\
& $\square$ RCRA \\
& $\square$ TPA\# \\
\end{tabular} & $\begin{array}{ll} & \text { DELIVERABLE: } \\
& \text { Report } \\
\square & \text { Letter } \\
\square & \text { Drawings } \\
\square & \text { Other } \\
\text { (specify) }\end{array}$ & $\begin{array}{l}\mathrm{Al} \\
\square \mathrm{DC} \\
\mathrm{DC} \\
0 \\
\square \\
\square\end{array}$ & \\
\hline \multicolumn{4}{|l|}{ Milestone Description } \\
\hline \multicolumn{4}{|c|}{$\begin{array}{l}\text { Submit a draft update of the } 1994 \text { Hanford SSSP to DOE-RL for review and } \\
\text { comment. }\end{array}$} \\
\hline \multicolumn{4}{|c|}{ Description of what constitutes completion of this milestone: } \\
\hline \multicolumn{4}{|l|}{ Provide draft report to $\mathrm{DOE}-\mathrm{RL}$} \\
\hline $\begin{array}{l}\text { Cost Account Manager } \\
\text { C. W. Walton }\end{array}$ & $\begin{array}{l}\text { Program/Project } \\
\text { C. W. Walton }\end{array}$ & lager & Date \\
\hline $\begin{array}{l}\text { Program Element Manager } \\
\text { C. J. Udell }\end{array}$ & $\begin{array}{l}\text { DOE Monitor } \\
\text { J. L. Spracklen }\end{array}$ & & Date \\
\hline
\end{tabular}


Westinghouse Hanford Company

MILESTONE DESCRIPTION SHEET

\begin{tabular}{|c|c|c|c|}
\hline \multicolumn{2}{|c|}{$\begin{array}{l}\text { Title: } \\
\text { Implement New Personnel Security Clearance Record System }\end{array}$} & $\begin{array}{l}\text { Date } \\
07 / 2\end{array}$ & \\
\hline \multicolumn{2}{|l|}{ Assigned To: W. J. Hawkins } & CIN: & \\
\hline \multicolumn{2}{|l|}{ WBS Designator: 6.6 .2 .1} & Due & $1 / 95$ \\
\hline \multicolumn{2}{|l|}{ Control Number: SSP-95-06 } & \multicolumn{2}{|c|}{ Revision: } \\
\hline \begin{tabular}{l|l} 
Milestone Type: & \multicolumn{1}{c}{ Division: } \\
$\begin{array}{l}\square \text { DOE-HQ } \\
\text { DOE-RL }\end{array}$ & $\square$ State \\
$\square$ CNTR & $\square$ Federal \\
& $\square$ DOE \\
& $\square$ RCRA \\
& $\square$ TPA\# \\
\end{tabular} & $\begin{array}{l}\text { DELIVERABLE: } \\
\square \text { Report } \\
\text { Letter } \\
\square \text { Drawings } \\
\square \text { Other } \\
\text { (specify) }\end{array}$ & 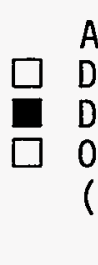 & To: \\
\hline \multicolumn{4}{|l|}{ Milestone Description } \\
\hline \multicolumn{4}{|c|}{$\begin{array}{l}\text { Complete development of a new Personnel Security Clearance Record (PSCR) } \\
\text { system application and transition the database from the current Honeywe } 17 \\
\text { computer to a modern file server. }\end{array}$} \\
\hline \multicolumn{4}{|c|}{ Description of what constitutes completion of this milestone: } \\
\hline \multicolumn{4}{|c|}{ Conversion from the current PSCR data base to the new data base. } \\
\hline $\begin{array}{l}\text { Cost Account Manager } \\
\text { C. W. WaTton }\end{array}$ & $\begin{array}{l}\text { Program/Project Ma } \\
\text { C. W. Walton }\end{array}$ & lager & Date \\
\hline $\begin{array}{l}\text { Program Element Manager } \\
\text { W. J. Hawkins }\end{array}$ & $\begin{array}{l}\text { DOE Monitor } \\
\text { J. L. Spracklen }\end{array}$ & & Date \\
\hline
\end{tabular}




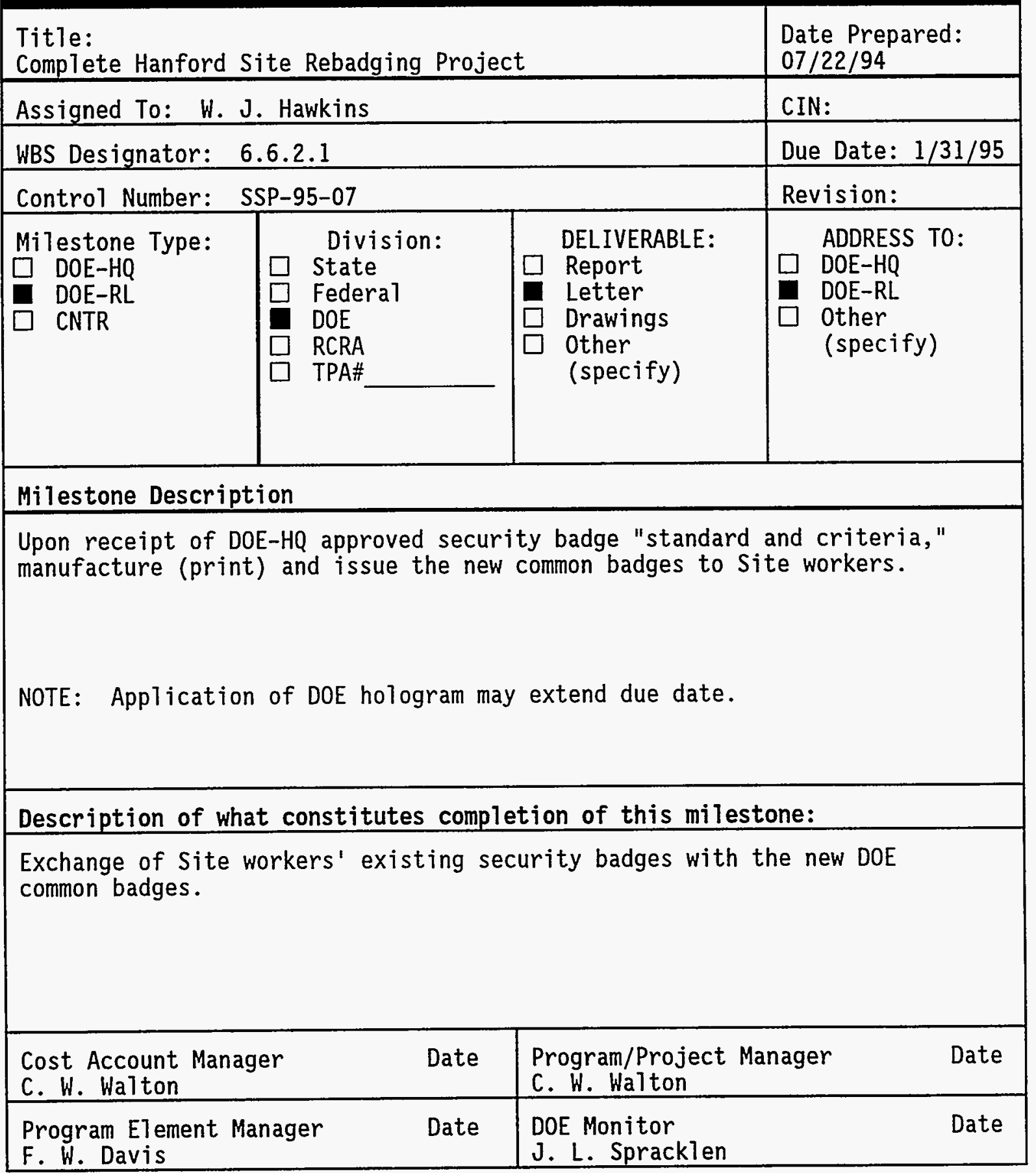




\begin{tabular}{|c|c|c|}
\hline \multicolumn{2}{|l|}{$\begin{array}{l}\text { Tit]e: } \\
1994 \text { Security Refresher Briefing }\end{array}$} & $\begin{array}{l}\text { Date Prepared: } \\
07 / 28 / 94\end{array}$ \\
\hline \multicolumn{2}{|l|}{ Assigned To: C. E. Braswell } & CIN: \\
\hline \multicolumn{2}{|l|}{ WBS Designator: 6.6 .2 .4} & Due Date: $3 / 31 / 95$ \\
\hline \multicolumn{2}{|l|}{ Control Number: SSP-95-08 } & Revision: \\
\hline \begin{tabular}{l|l} 
Milestone Type: & \multicolumn{1}{c}{ Division: } \\
$\square$ DOE-HQ & $\square$ State \\
DOE-RL & $\square$ Federal \\
$\square$ CNTR & $\square$ DOE \\
& $\square$ RCRA \\
& $\square$ TPA\# \\
\end{tabular} & $\begin{array}{l}\text { DELIVERABLE: } \\
\text { Report } \\
\square \text { Letter } \\
\square \text { Drawings } \\
\square \text { Other } \\
\text { (specify) }\end{array}$ & $\begin{array}{l}\text { ADDRESS TO: } \\
\square \text { DOE-HQ } \\
\text { DOE-RL } \\
\square \text { Other } \\
\text { (specify) }\end{array}$ \\
\hline \multicolumn{3}{|l|}{ Milestone Description } \\
\hline \multicolumn{3}{|c|}{$\begin{array}{l}\text { Ensure a } 11 \text { cleared active WHC/BCSR/ICF KH employees complete the Security } \\
\text { Refresher briefing in compliance with DOE Order } 5631.1 \mathrm{~B} \text {, by March } 31 \text {, } 1995 .\end{array}$} \\
\hline \multicolumn{3}{|c|}{ Description of what constitutes completion of this milestone: } \\
\hline \multicolumn{3}{|c|}{$\begin{array}{l}\text { WHC Security Education will work closely with WHC Training Records to } \\
\text { ensure completion of the requirement stated above. A letter of completion } \\
\text { will be submitted to RL. }\end{array}$} \\
\hline $\begin{array}{l}\text { Cost Account Manager } \\
\text { C. W. Walton }\end{array}$ & $\begin{array}{l}\text { Program/Project } \\
\text { C.W. Walton }\end{array}$ & lager \\
\hline $\begin{array}{l}\text { Program Element Manager } \\
\text { D. J. Haskins }\end{array}$ & $\begin{array}{l}\text { DOE Monitor } \\
\text { J. L. Spracklen }\end{array}$ & Date \\
\hline
\end{tabular}


Tit7e:

1995 Security Refresher Briefing

Date Prepared:

Assigned To: C. E. Braswell

$07 / 28 / 94$

WBS Designator: 6.6.2.4

CIN:

Control Number: SSP-95-09

Milestone Type:

DOE-HQ

DOE-RL

CNTR

$\begin{array}{ll} & \text { Division: } \\ & \text { State } \\ \square & \text { Federal } \\ \text { DOE } \\ \text { RCRA } \\ \square \text { TPA\# } \\ \end{array}$

Due Date: 1/1/95

(2)

Milestone Description

Develop the 1995 Security Refresher Briefing for presentation on the Hanford General Employee Training (HGET) program and submit to Advanced Training Technologies for implementation by January 1, 1995.

Description of what constitutes completion of this milestone:

After submittal of Lesson PIan to WHC Advanced Training Technologies, a letter of completion will be submitted to RL.

\begin{tabular}{|ll|ll|}
\hline $\begin{array}{l}\text { Cost Account Manager } \\
\text { C.W. Walton }\end{array}$ & Date & $\begin{array}{l}\text { Program/Project Manager } \\
\text { C.W. Walton }\end{array}$ & Date \\
\hline $\begin{array}{l}\text { Program Element Manager } \\
\text { D. J. Haskins }\end{array}$ & Date & $\begin{array}{l}\text { DOE Monitor } \\
\text { J.L. Spracklen }\end{array}$ & Date \\
\hline
\end{tabular}




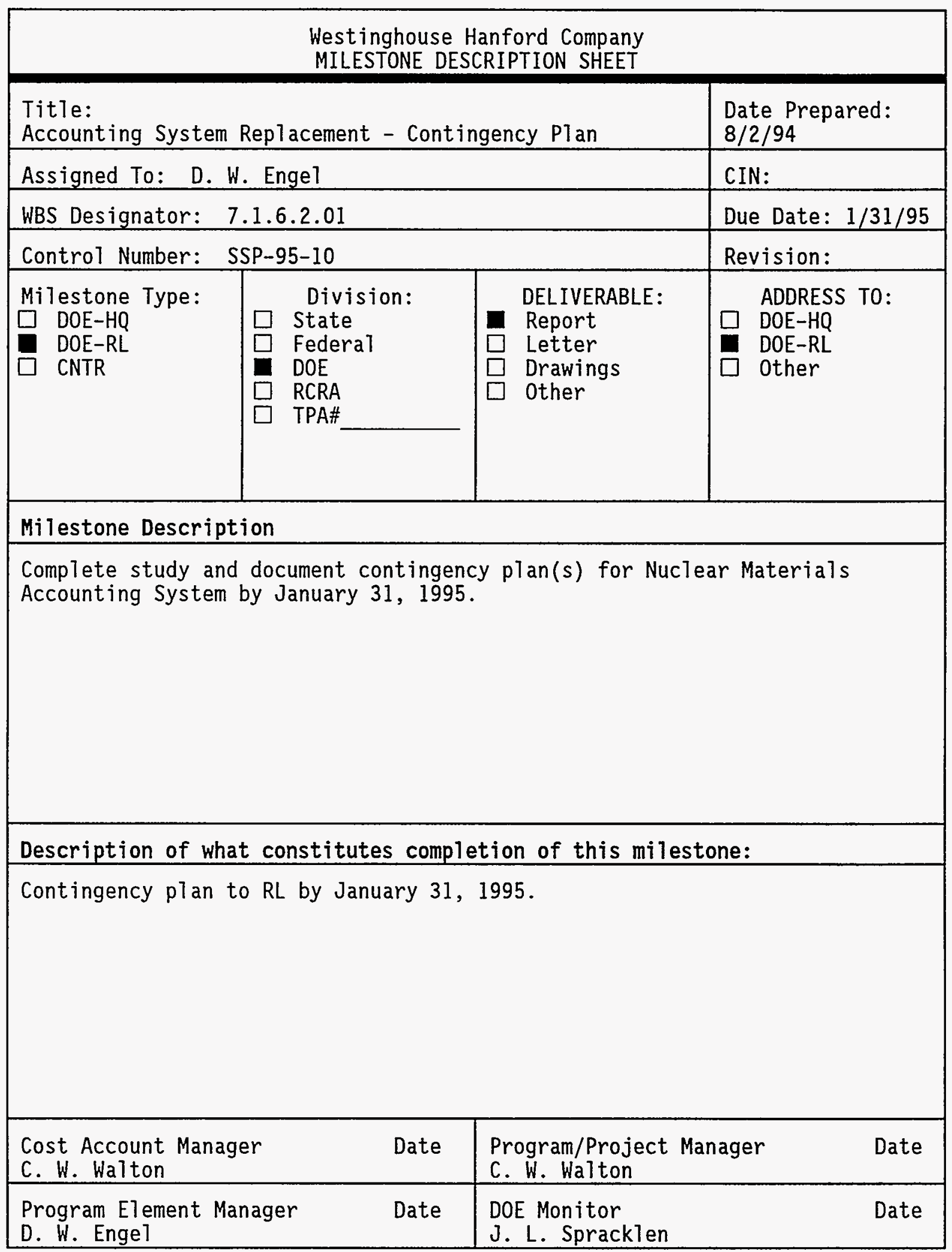




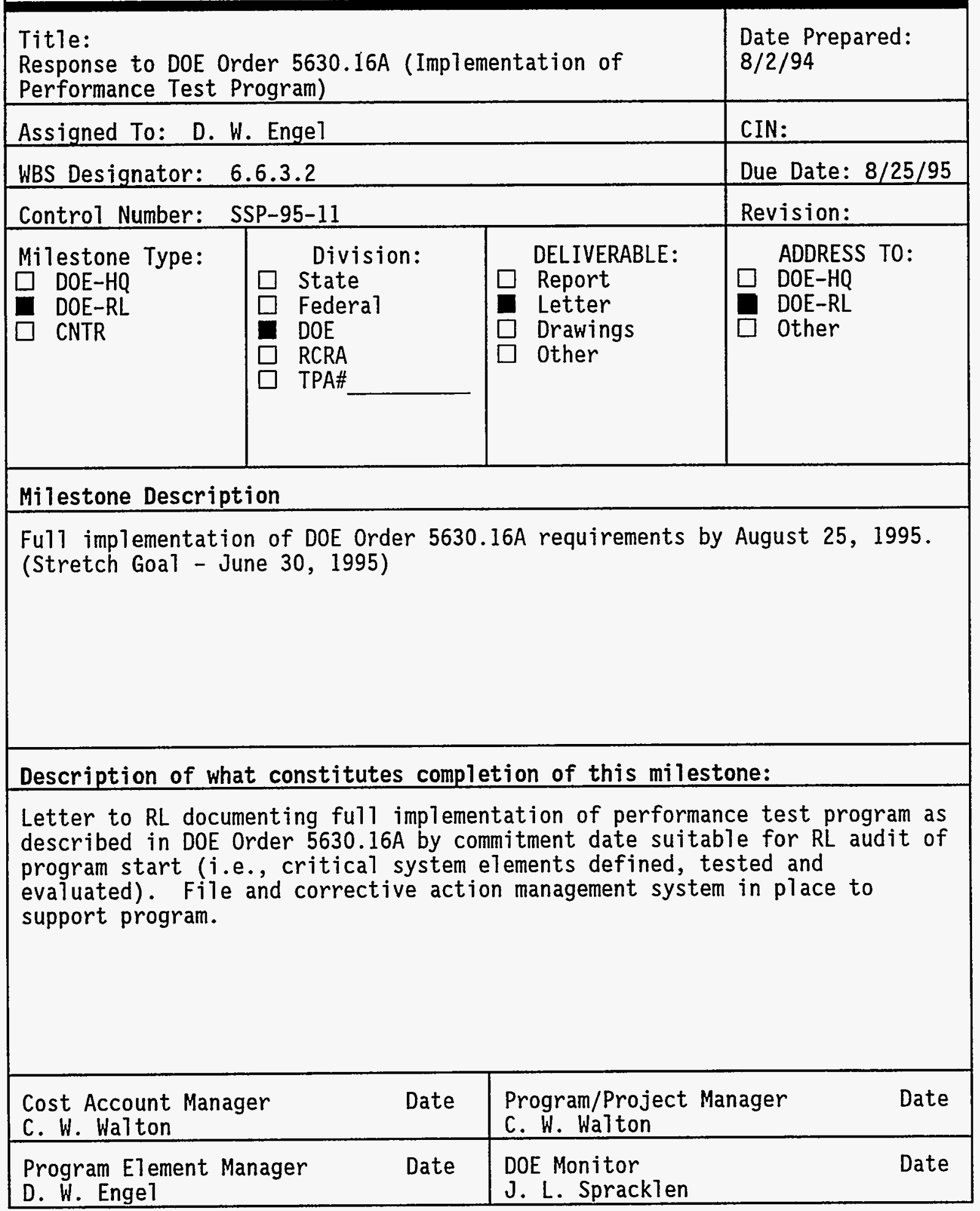




\section{Westinghouse Hanford Company MILESTONE DESCRIPTION SHEET}

\section{Title:}

Develop computer assisted training package for classified computer users in WHC

Assigned To: J. T. Stowe CIN:

WBS Designator: 6.6.2.2 Due Date: 6/30/95

Control Number: SSP-95-12

Milestone Type:

$\square$ DOE-HQ

DOE-RL

$\square$ CNTR

$\begin{array}{ll} & \text { Division: } \\ \square & \text { State } \\ \square & \text { Federal } \\ \text { DOE } \\ \square \text { RCRA } \\ \square \text { TPA\# }\end{array}$

\begin{tabular}{|l|l|} 
& DELIVERABLE: \\
$\square$ & Report \\
$\square$ & Letter \\
$\square$ & Drawings \\
Other: \\
Computer \\
Software
\end{tabular}

Revision:

Date Prepared:

08/10/94

ADDRESS TO:

$\square$ DOE-HQ

DOE-RL

$\square$ Other

(specify)

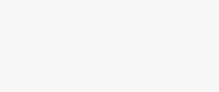

\section{Milestone Description}

Develop a new computer assisted training package for classified computer users in WHC.

\section{Description of what constitutes completion of this milestone:}

Demonstration of the program to the RL Computer Security Operation Manager.

\begin{tabular}{|ll|ll|}
\hline $\begin{array}{l}\text { Cost Account Manager } \\
\text { C.W. Walton }\end{array}$ & Date & $\begin{array}{l}\text { Program/Project Manager } \\
\text { C.W. Walton }\end{array}$ & Date \\
\hline $\begin{array}{l}\text { Program Element Manager } \\
\text { J. T. Stowe }\end{array}$ & Date & $\begin{array}{l}\text { DOE Monitor } \\
\text { J.L. Spracklen }\end{array}$ & Date \\
\hline
\end{tabular}




\section{Westinghouse Hanford Company}

MILESTONE DESCRIPTION SHEET

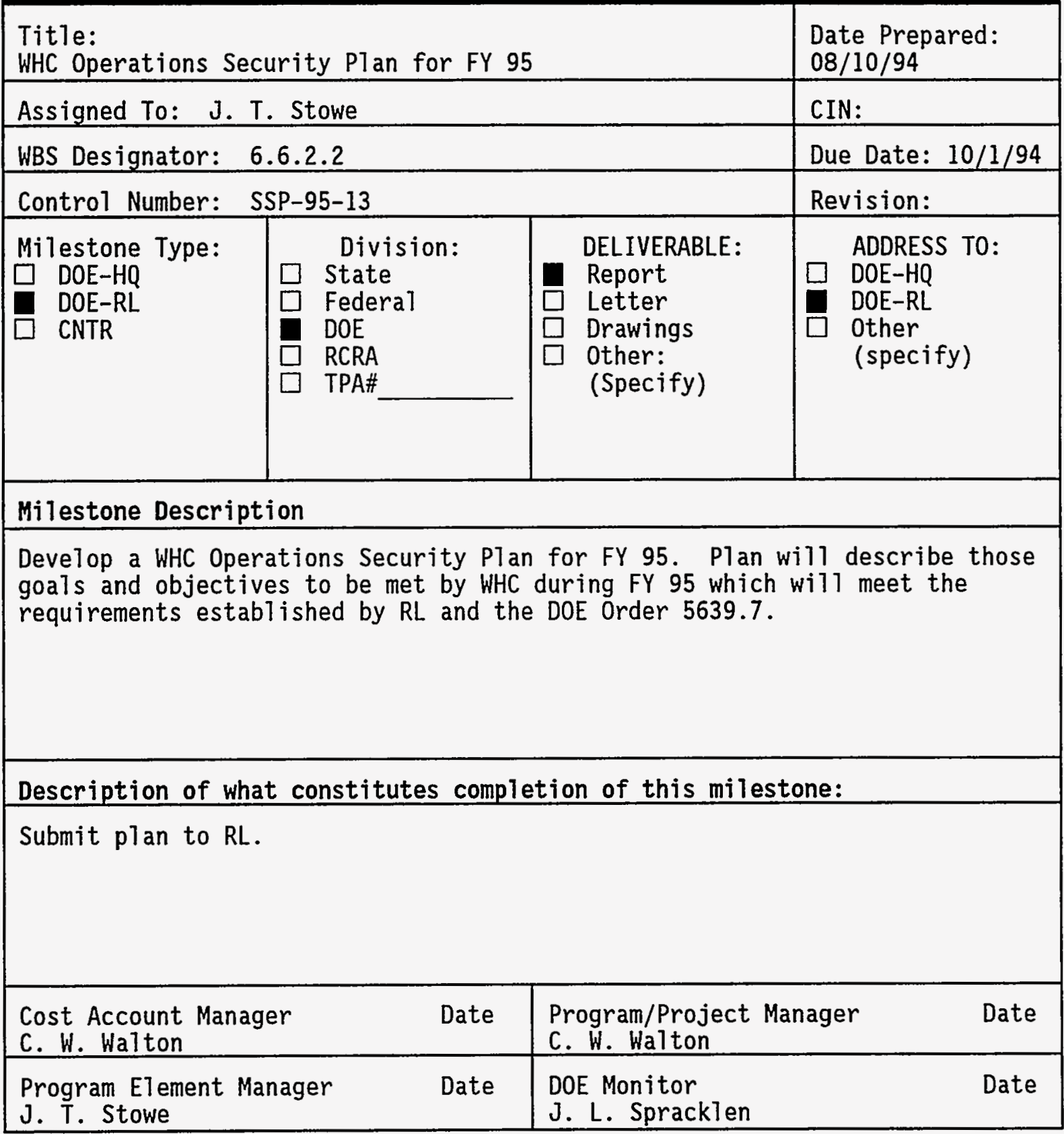


Westinghouse Hanford Company

MILESTONE DESCRIPTION SHEET

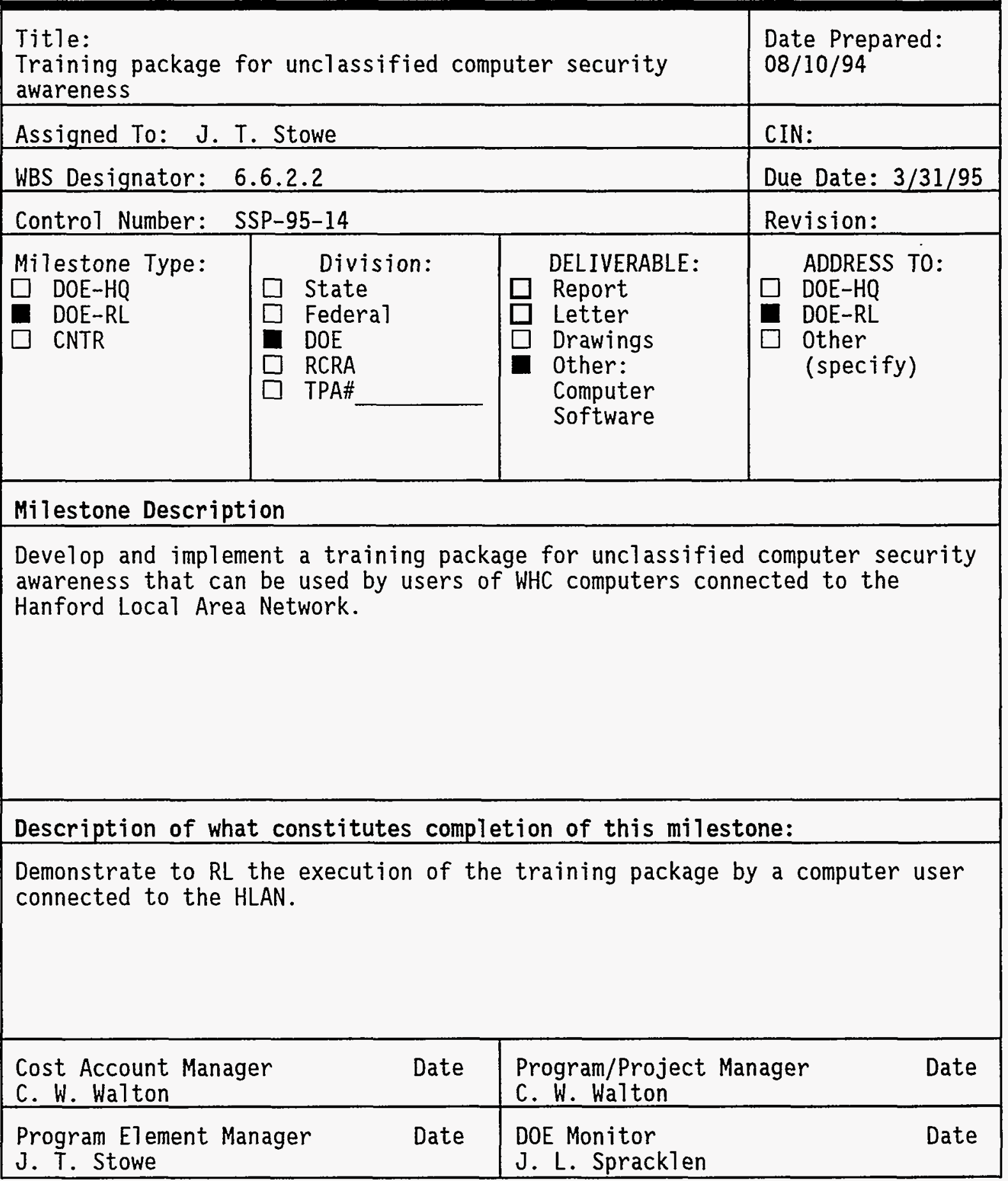


Westinghouse Hanford Company

MILESTONE DESCRIPTION SHEET

Title:

Update/revise the WHC Computer Protection Program P7an

Date Prepared:

$08 / 10 / 94$

Assigned To: J. T. Stowe

CIN:

WBS Designator: 6.6.2.2

Due Date: 6/30/95

Control Number: SSP-95-15

Milestone Type:

$\square$ DOE-HQ

DOE-RL

CNTR

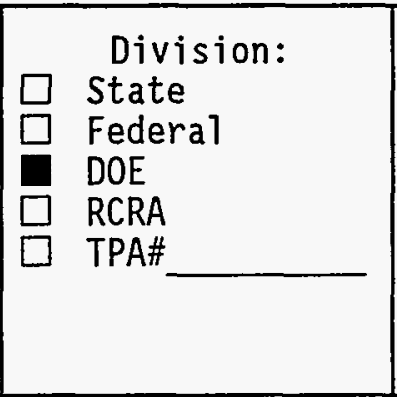

Revision:

DELIVERABLE:

Report

Letter

$\square$ Drawings

Other:

(Specify)

ADDRESS TO:

$\square$ DOE-HQ

DOE-RL

$\square$ Other

(specify)

Milestone Description

Update and revise the WHC Computer Protection Program $\mathrm{Plan}$ that is required under DOE Order 1360.2B.

Description of what constitutes completion of this milestone:

Delivery of the completed protection plan to RL.

\begin{tabular}{|ll|ll|}
\hline $\begin{array}{l}\text { Cost Account Manager } \\
\text { C. W. Walton }\end{array}$ & Date & $\begin{array}{l}\text { Program/Project Manager } \\
\text { C. W. Walton }\end{array}$ & Date \\
\hline $\begin{array}{l}\text { Program Element Manager } \\
\text { J. T. Stowe }\end{array}$ & Date & $\begin{array}{l}\text { DOE Monitor } \\
\text { J. L. Spracklen }\end{array}$ & Date \\
\hline
\end{tabular}




\begin{tabular}{|c|c|c|c|c|}
\hline \multicolumn{5}{|c|}{$\begin{array}{l}\text { Westinghouse Hanford Company } \\
\text { MILESTONE DESCRIPTION SHEET }\end{array}$} \\
\hline \multicolumn{3}{|l|}{$\begin{array}{l}\text { Title: } \\
\text { Internal Audit Program }\end{array}$} & $\begin{array}{l}\text { Date } \\
8 / 2 / 9\end{array}$ & \\
\hline \multicolumn{3}{|l|}{ Assigned To: D. W. Engel } & CIN: & \\
\hline \multicolumn{3}{|l|}{ WBS Designator: 6.6 .3 .2} & Due [ & $28 / 95$ \\
\hline \multicolumn{3}{|c|}{ Control Number: SSP-95-16 } & Revis & \\
\hline \begin{tabular}{l|ll} 
Milestone Type: & \\
$\square$ DOE-HQ & $\square$ & S \\
$\square$ DOE-RL & $\square$ & F \\
& CNTR & \\
& $\square$ & R \\
& $\square$ & $T$
\end{tabular} & & $\begin{array}{l}\text { DELIVERABLE: } \\
\square \text { Report } \\
\text { Letter } \\
\square \text { Drawings } \\
\square \text { Other }\end{array}$ & $\begin{array}{ll} & \mathrm{AL} \\
\square & \mathrm{DC} \\
\square & \mathrm{DC} \\
\square & 0\end{array}$ & \\
\hline \multicolumn{5}{|l|}{ Milestone Description } \\
\hline \multicolumn{5}{|c|}{ Outsource WHC SAS internal survey program by February 28, 1995.} \\
\hline \multicolumn{5}{|c|}{ Description of what constitutes completion of this milestone: } \\
\hline \multicolumn{5}{|c|}{$\begin{array}{l}\text { Letter to RL describing results of study with cost estimates and prepared } \\
\text { schedules for outsourcing internal audit program. }\end{array}$} \\
\hline $\begin{array}{l}\text { Cost Account Manager } \\
\text { C. W. Walton }\end{array}$ & Date & $\begin{array}{l}\text { Program/Project } \\
\text { C. W. Walton }\end{array}$ & nager & Date \\
\hline $\begin{array}{l}\text { Program Element Manager } \\
\text { D. W. Engel }\end{array}$ & Date & $\begin{array}{l}\text { DOE Monitor } \\
\text { J. L. Spracklen }\end{array}$ & & Date \\
\hline
\end{tabular}


Westinghouse Hanford Company MILESTONE DESCRIPTION SHEET

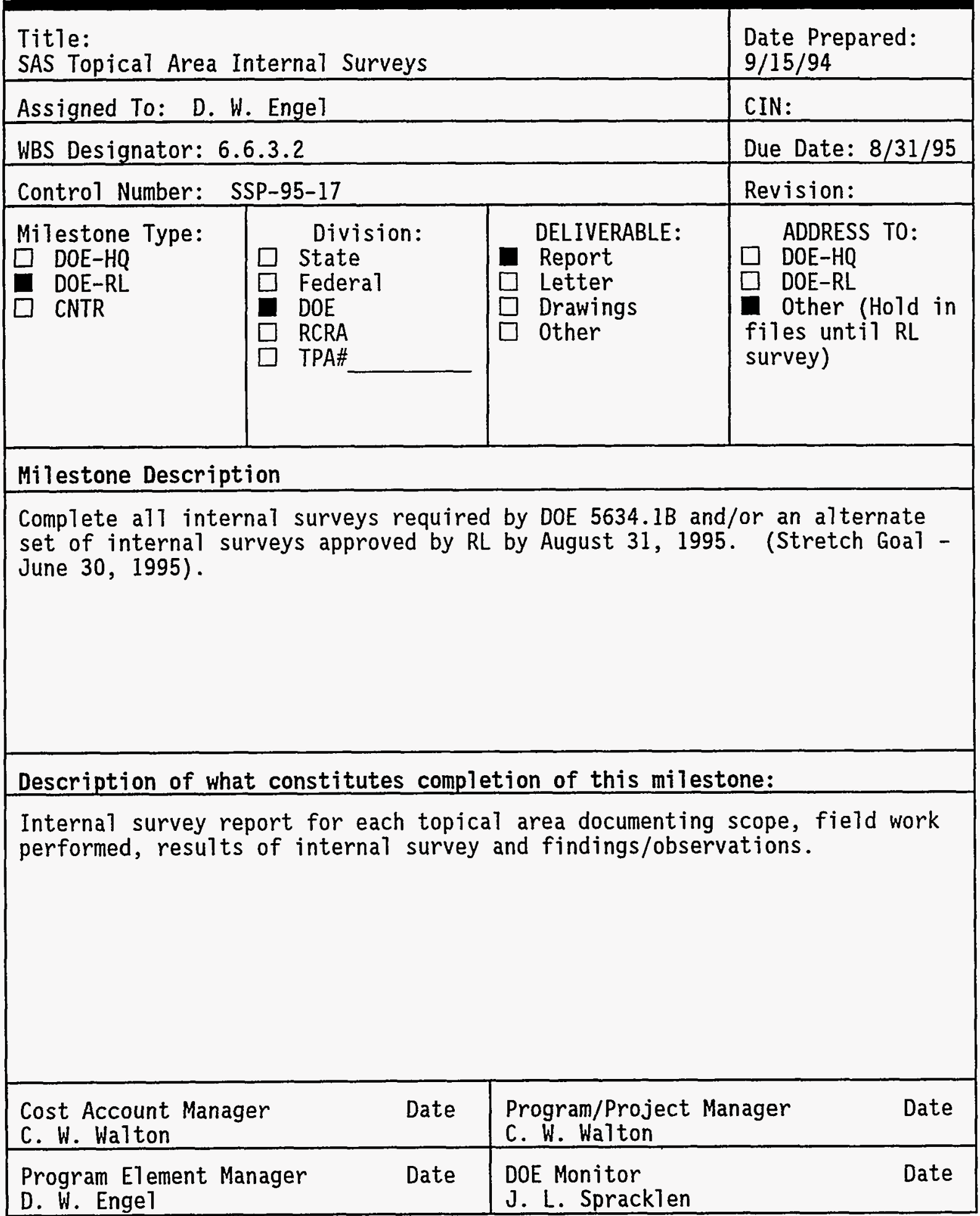




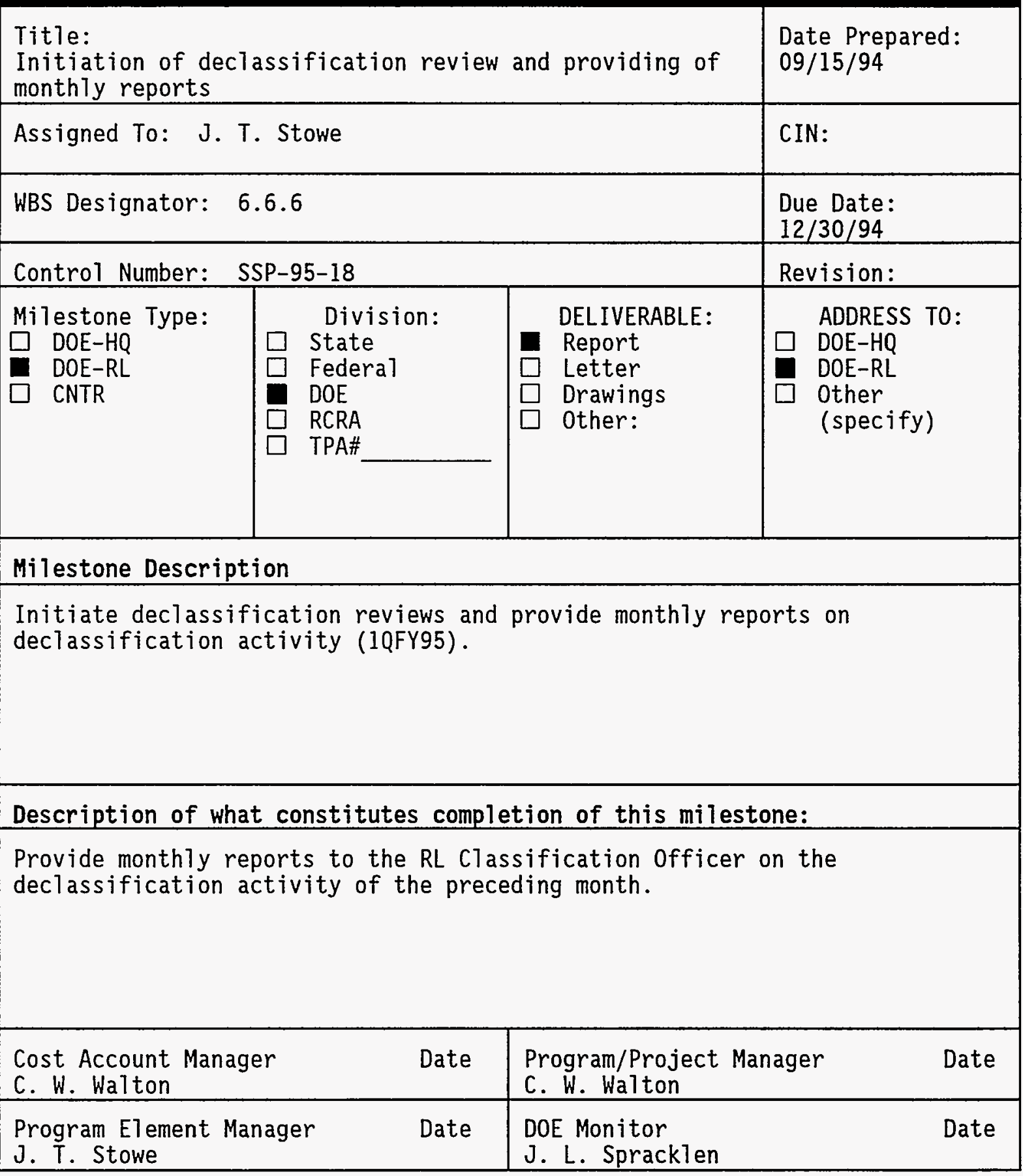


Westinghouse Hanford Company

MILESTONE DESCRIPTION SHEET

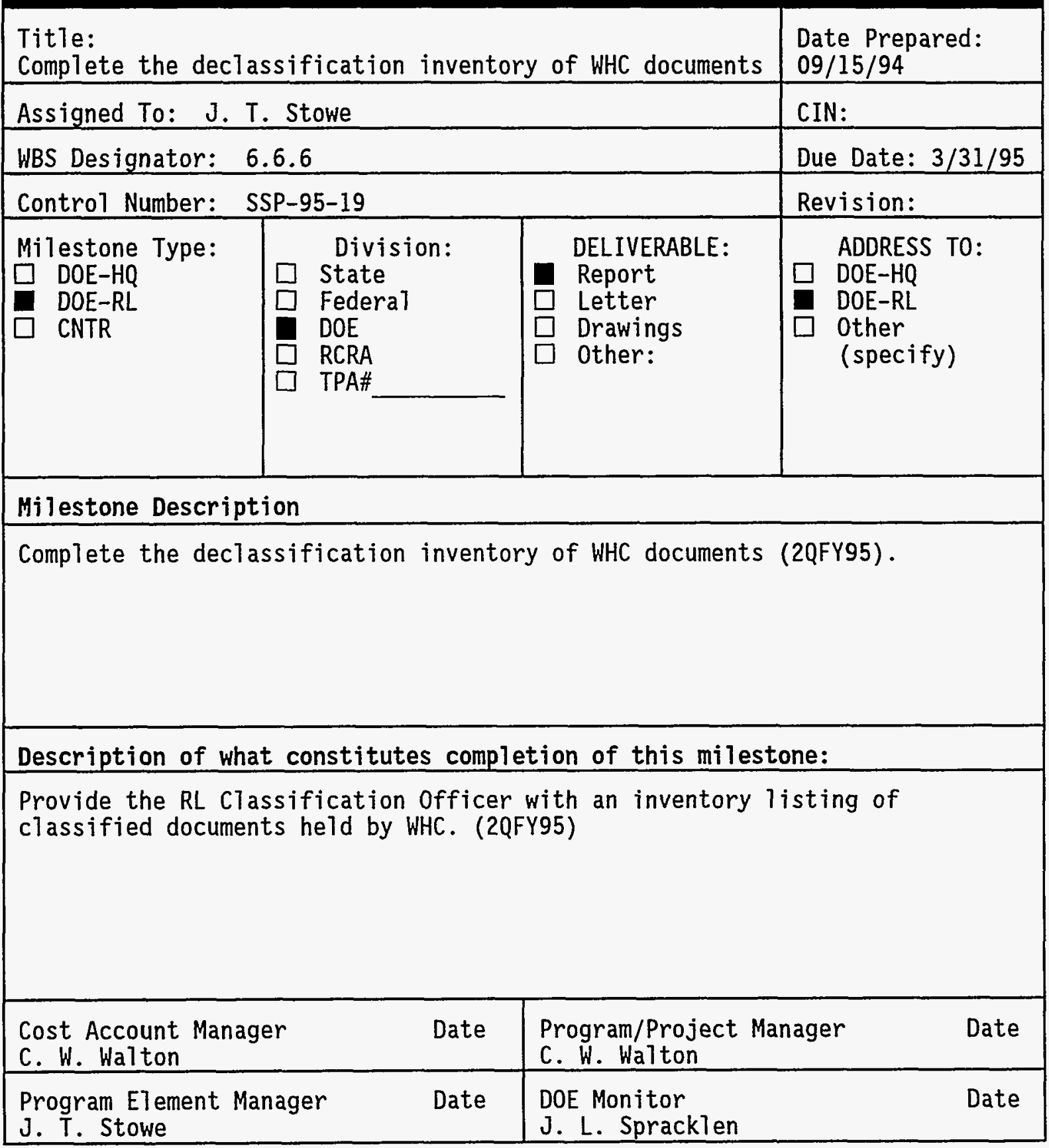

